\title{
GEOCHEMISTRY OF THE CAMBRIAN-ORDOVICIAN AQUIFER SYSTEM IN THE NORTHERN MIDWEST, UNITED STATES
}

\section{PEEIONAI AOUIFARCSVSTIM ANALYSIS}

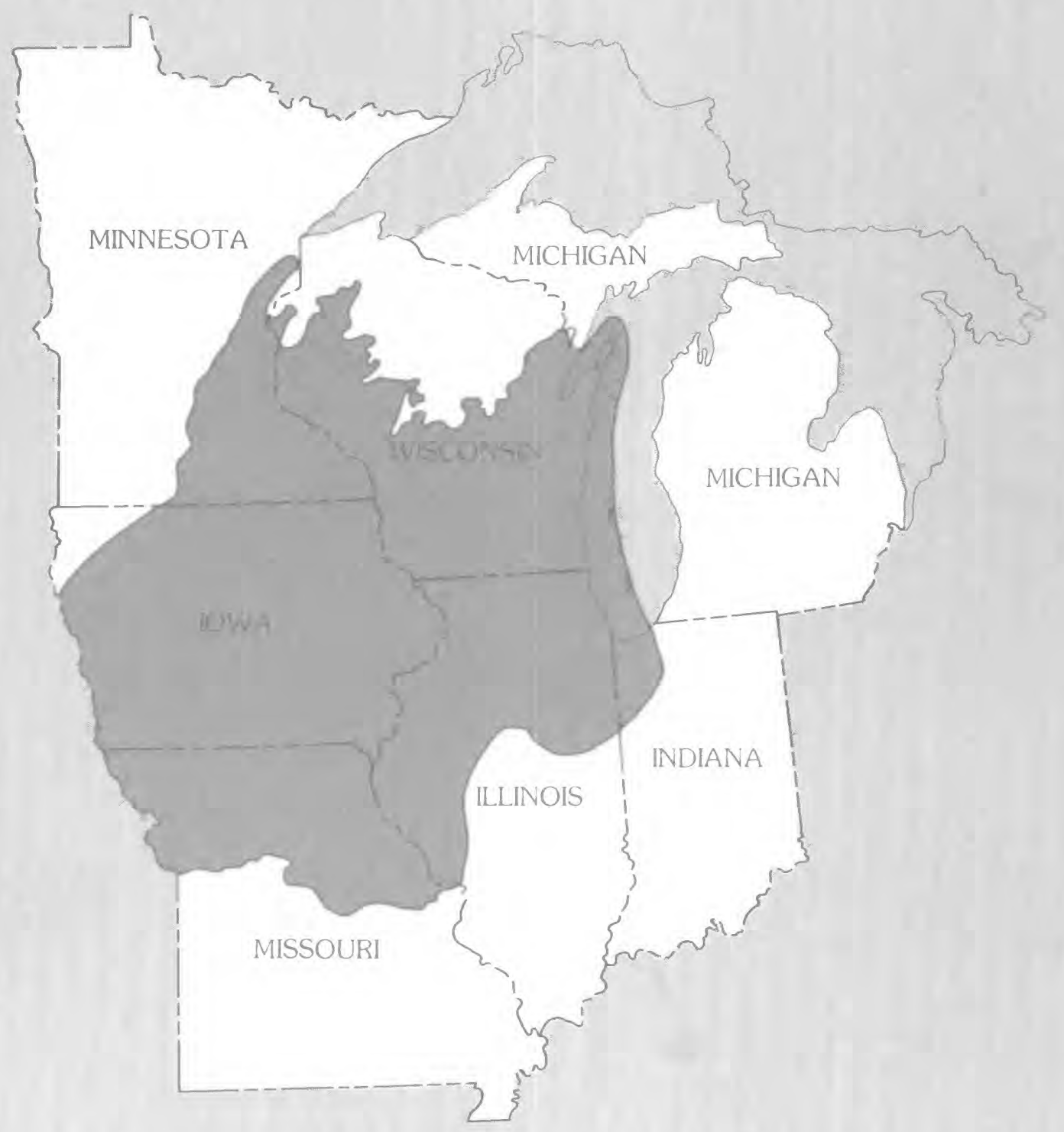




\section{AVAILABILITY OF BOOKS AND MAPS OF THE U.S. GEOLOGICAL SURVEY}

Instructions on ordering publications of the U.S. Geological Survey, along with prices of the last offerings, are given in the current-year issues of the monthly catalog "New Publications of the U.S. Geological Survey." Prices of available U.S. Geological Survey publications released prior to the current year are listed in the most recent annual "Price and Availability List." Publications that are listed in various U.S. Geological Survey catalogs (see back inside cover) but not listed in the most recent annual "Price and Availability List" are no longer available.

Prices of reports released to the open files are given in the listing "U.S. Geological Survey Open-File Reports," updated monthly, which is for sale in microfiche from the U.S. Geological Survey, Books and Open-File Reports Section, Federal Center, Box 25425, Denver, CO 80225 . Reports released through the NTIS may be obtained by writing to the National Technical Information Service, U.S. Department of Commerce, Springfield, VA 22161; please include NTIS report number with inquiry.

Order U.S. Geological Survey publications by mail or over the counter from the offices given below.

BY MAIL

\section{Books}

Professional Papers, Bulletins, Water-Supply Papers, Techniques of Water-Resources Investigations, Circulars, publications of general interest (such as leaflets, pamphlets, booklets), single copies of Earthquakes \& Volcanoes, Preliminary Determination of Epicenters, and some miscellaneous reports, including some of the foregoing series that have gone out of print at the Superintendent of Documents, are obtainable by mail from

\section{U.S. Geological Survey, Books and Open-File Reports Federal Center, Box 25425 \\ Denver, CO 80225}

Subscriptions to periodicals (Earthquakes \& Volcanoes and Preliminary Determination of Epicenters) can be obtained ONLY from the

\section{Superintendent of Documents \\ Government Printing Office \\ Washington, D.C. 20402} ments.)

(Check or money order must be payable to Superintendent of Docu-

\section{Maps}

For maps, address mail orders to

\section{U.S. Geological Survey, Map Distribution Federal Center, Box 25286 Denver, CO 80225}

Residents of Alaska may order maps from

\author{
Alaska Distribution Section, U.S. Geological Survey, \\ New Federal Building - Box 12 \\ 101 Twelfth Ave., Fairbanks, AK 99701
}

\section{OVER THE COUNTER}

\section{Books}

Books of the U.S. Geological Survey are available over the counter at the following Geological Survey Public Inquiries Offices, all of which are authorized agents of the Superintendent of Documents:

- WASHINGTON, D.C.--Main Interior Bldg., 2600 corridor, 18 th and C Sts., NW.

- DENVER, Colorado--Federal Bldg., Rm. 169, 1961 Stout St.

- LOS ANGELES, California--Federal Bldg., Rm. 7638, 300 N. Los Angeles St.

- MENLO PARK, California--Bldg. 3 (Stop 533), Rm. 3128, 345 Middlefield Rd.

- RESTON, Virginia--503 National Center, Rm. 1C402, 12201 Sunrise Valley Dr.

- SALT LAKE CITY, Utah--Federal Bldg., Rm. 8105, 125 South State St.

- SAN FRANCISCO, California--Customhouse, Rm. 504, 555 Battery St.

- SPOKANE, Washington--U.S. Courthouse, Rm. 678, West 920 Riverside Ave.

- ANCHORAGE, Alaska--Rm. 101, 4230 University Dr.

- ANCHORAGE, Alaska--Federal Bldg, Rm. E-146, 701 C St.

$\cdot$

Maps

Maps may be purchased over the counter at the U.S. Geological Survey offices where books are sold (all addresses in above list) and at the following Geological Survey offices:

- ROLLA, Missouri--1400 Independence Rd.

- DENVER, Colorado--Map Distribution, Bldg. 810, Federal Center

- FAIRBANKS, Alaska--New Federal Bldg., 101 Twelfth Ave. 


\title{
Geochemistry of the Cambrian- Ordovician Aquifer System in the Northern Midwest, United States
}

\author{
By D.I. SIEGEL
}

REGIONAL AQUIFER-SYSTEM ANALYSIS-

NORTHERN MIDWEST AQUIFER SYSTEM

U.S.GEOLOGICAL SURVEY PROFESSIONAL PAPER 1405-D

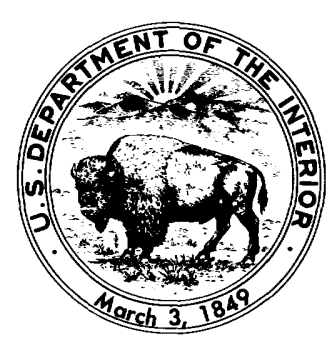




\section{DEPARTMENT OF THE INTERIOR}

MANUEL LUJAN, JR., Secretary

\section{U.S. GEOLOGICAL SURVEY}

Dallas L. Peck, Director

Any use of trade, product, or firm names in this publication is for descriptive purposes only and does not imply endorsement by the U.S. Government

Library of Congress Cataloging in Publication Data

Siegel, Donald I.

Geochemistry of the Cambrian-Ordovician aquifer system in the Northern Midwest, United States.

(U.S. Geological Survey professional paper ; 1405-D

Bibliography: $p$.

Supt. of Docs. no.: I 19.16:1405-D

1. Water-Composition-Middle West. 2. Geochemistry-Middle West. 3. Aquifers-Middle West.

4. Geology, Stratigraphic-Cambrian. 5. Geology, Stratigraphic-Ordovician. 6. Geology-Middle West.

I. Title. II Series.

GB857.2.M53S54 $1989 \quad 557.3 \mathrm{~s} \quad 87-600044$

[553.7'9'0977]

For sale by the Books and Open-File Reports Section, U.S. Geological Survey,

Federal Center, Box 25425, Denver, CO 80225 


\section{FOREWORD}

\section{THE REGIONAL AQUIFER-SYSTEM ANALYSIS PROGRAM}

The Regional Aquifer-System Analysis (RASA) Program was started in 1978 following a congressional mandate to develop quantitative appraisals of the major ground-water systems of the United States. The RASA Program represents a systematic effort to study a number of the Nation's most important aquifer systems, which in aggregate underlie much of the country and which represent an important component of the Nation's total water supply. In general, the boundaries of these studies are identified by the hydrologic extent of each system and accordingly transcend the political subdivisions to which investigations have often arbitrarily been limited in the past. The broad objective for each study is to assemble geologic, hydrologic, and geochemical information, to analyze and develop an understanding of the system, and to develop predictive capabilities that will contribute to the effective management of the system. The use of computer simulation is an important element of the RASA studies, both to develop an understanding of the natural, undisturbed hydrologic system and the changes brought about in it by human activities, and to provide a means of predicting the regional effects of future pumping or other stresses.

The final interpretive results of the RASA Program are presented in a series of U.S. Geological Survey Professional Papers that describe the geology, hydrology, and geochemistry of each regional aquifer system. Each study within the RASA Program is assigned a single Professional Paper number, and where the volume of interpretive material warrants, separate topical chapters that consider the principal elements of the investigation may be published. The series of RASA interpretive reports begins with Professional Paper 1400 and thereafter will continue in numerical sequence as the interpretive products of subsequent studies become available.

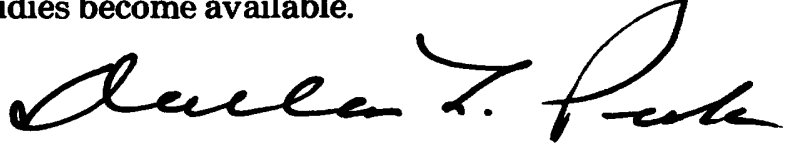

Dallas L. Peck Director 



\section{CONTENTS}

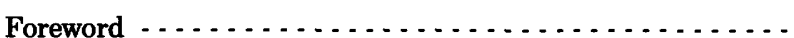

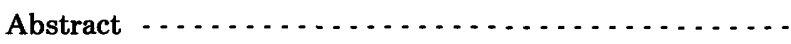

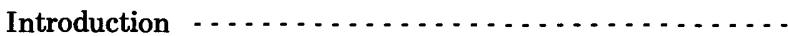

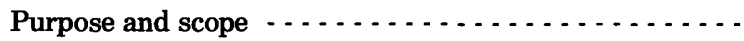

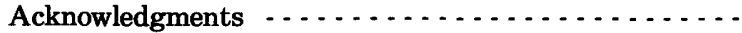

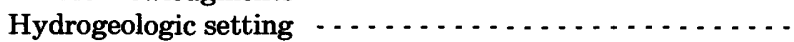

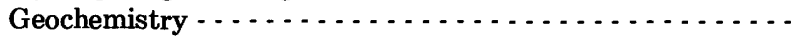

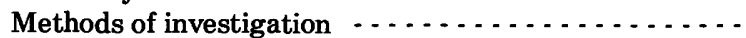

Dissolved solids - . . . . . . . . . . . . . . . . .

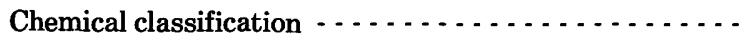

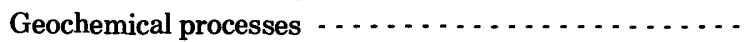

Calcium-magnesium-bicarbonate water type
Page

D1

1

2

2

2

7

7

10

10

15

15
Geochemistry-Continued

Geochemical processes-Continued

Calcium-sodium-sulfate-bicarbonate water type - . - $\quad$ D17

Sodium-mixed anion water type $\ldots \ldots \ldots . . . . .21$

Trace and minor constituents ................. 23

Isotopic composition of water and Pleistocene

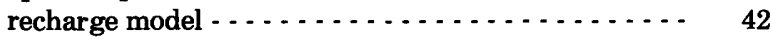

Hypothetical geochemical models $\ldots . . . \ldots \ldots \ldots$

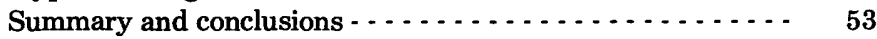

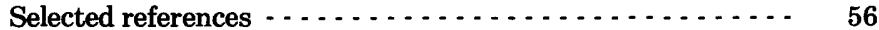

Chemical and isotopic analyses of ground water sampled

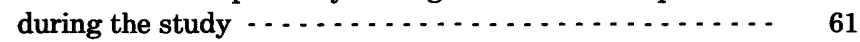

\section{ILLUSTRATIONS}

\section{Figures 1, 2. Maps showing:}

1. Location and general features of the Northern Midwest Regional Aquifer-System Analysis area - . . . . . .

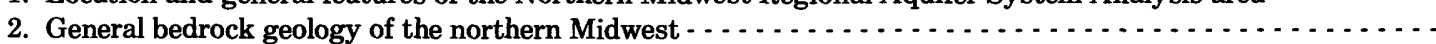

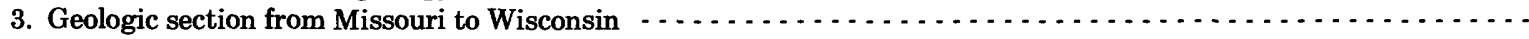
4-9. Maps showing:

4. Simulated predevelopment discharge areas for aquifer layers 1,2 , and $3 \ldots \ldots \ldots \ldots$

5. Approximate predevelopment potentiometric surface for aquifer layer $3 \ldots \ldots \ldots \ldots$

6. Location of wells with water-quality analyses and location of geochemical sections $A \cdot A^{\prime}$ and $B-B^{\prime} \quad \ldots \ldots \ldots$

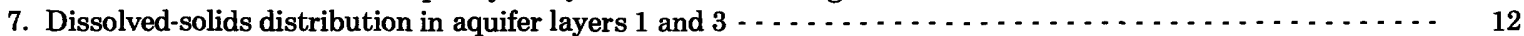

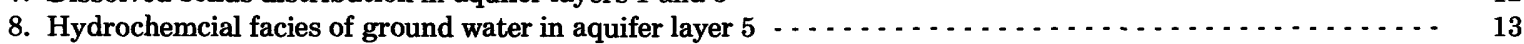

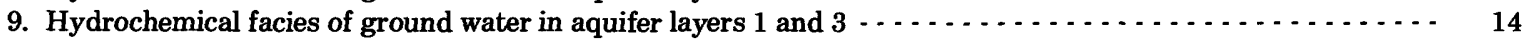

10. Diagram showing correlation of calcium plus magnesium and bicarbonate in ground water from the Ca- $\mathrm{Mg}-\mathrm{HCO}$

facies in aquifer layers 1, 3, and 5 in the northern outcrop area of the Cambrian-Ordovician aquifer system -...

11, 12. Maps showing saturation indices for-

11. Calcite and dolomite in water from selected wells in aquifer layer 3 in Iowa and northeastern Missouri -. . -

12. Gypsum in water from selected wells in aquifer layer 3 in Iowa and northeastern Missouri . . . . . . . . . . 13, 14. Maps showing:

13. Sulfate distribution in aquifer layers 1 and 3 and sulfur isotopic composition in sulfate in water from selected wells in aquifer layer 3 and aquifer layer 5 (Dakota Formation) $\ldots \ldots \ldots \ldots \ldots \ldots$

14. Sulfide distribution in water from selected wells in aquifer layer 3 in Iowa $\ldots . . . . . . . . . . .$.

15. Trilinear diagram of water chemistry along geochemical sections $A-A^{\prime}$ and $B-B^{\prime} \ldots \ldots \ldots \ldots \ldots \ldots$

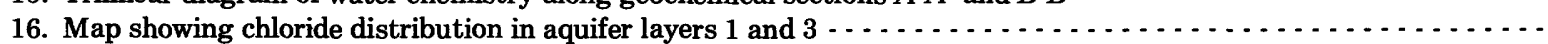

17, 18. Graphs showing:

17. Concentrations of major cations in water from wells in aquifer layers 1 and 3 along geochemical

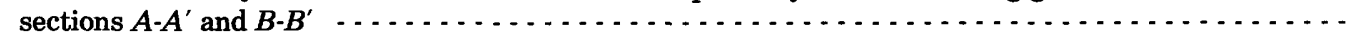

18. Concentrations of major anions in water from wells in aquifer layers 1 and 3 along geochemical sections

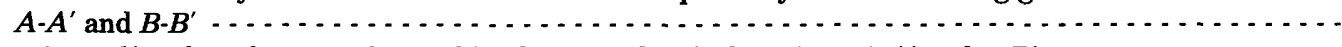

19. Diagram showing sulfate-bicarbonate relationship along geochemical sections $A-A^{\prime}$ and $B-B^{\prime} \ldots \ldots \ldots$ . (1) . is 
Figures 20-30. Maps showing distribution of dissolved:

20. Cadmium, arsenic, and selenium in aquifer layers 1 and $3 \ldots \ldots \ldots$

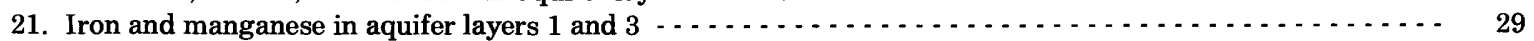

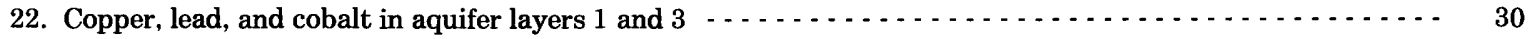

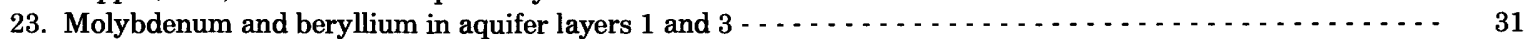

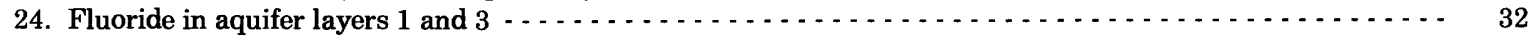

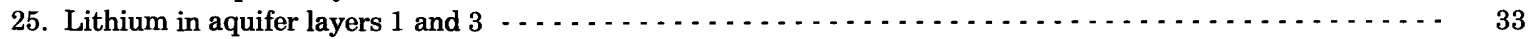

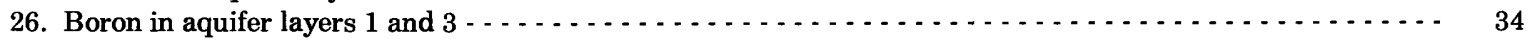

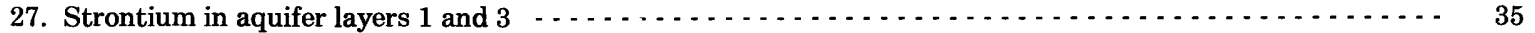

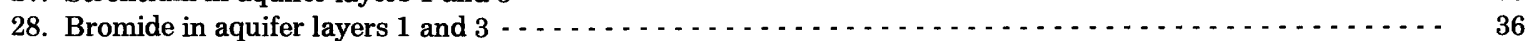

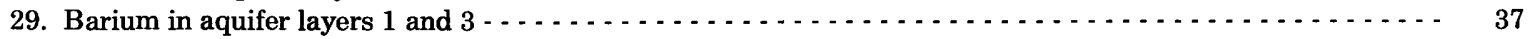

30. Silica and ground-water temperature in aquifer layers 1 and $3 \ldots \ldots \ldots \ldots$

31. Maps showing saturation indices for quartz and chalcedony in water from selected wells in aquifer layer 3 in

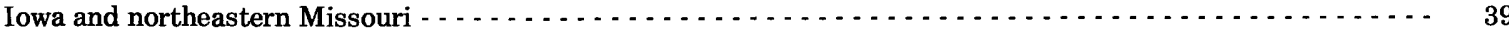

32. Diagram showing comparison of dissolved silica concentration and the solubility of quartz with water temperature in southwestern and southern Iowa and northeastern Missouri $\ldots \ldots \ldots \ldots$ 33, 34. Maps showing:

33. Distribution of dissolved uranium and radium-226 in aquifer layers 1 and $3 \ldots \ldots \ldots$

34. Extent of major glaciations in the northern Midwest during the Pleistocene Epoch . . . . . . . . . . .

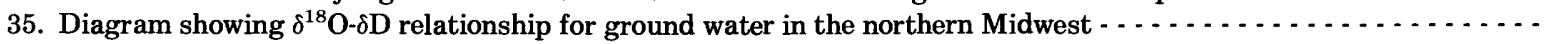
36-40. Maps showing:

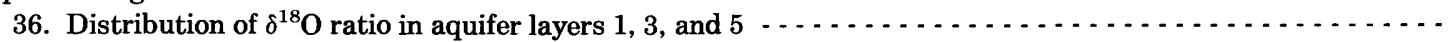

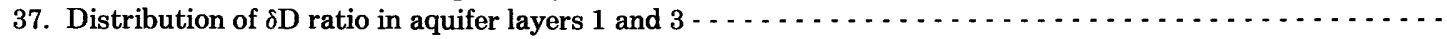

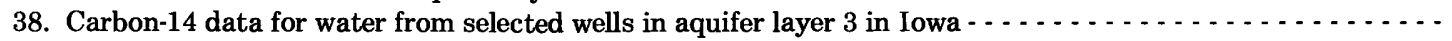

39. Assumed hydraulic head for aquifer layer 5 incorporating effects of ice thickness at the average advance

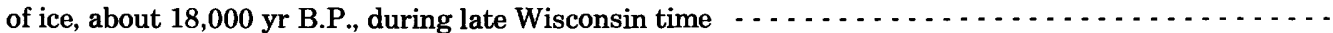

40. Simulated hydraulic head in aquifer layer 3 at the average advance of ice, about 18,000 yr B.P.,

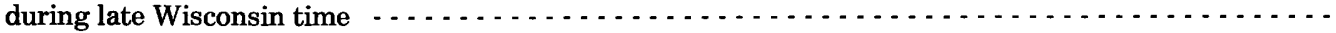

41. Diagram showing hypothetical geochemical models for the evolution of water chemistry in the

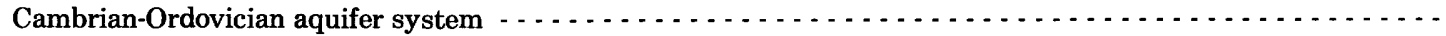

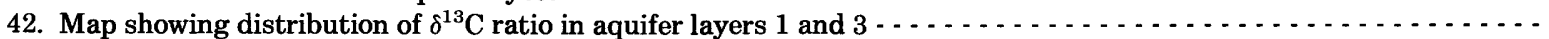

\section{TABLES}

TABLE $\quad$ 1. Chemical analyses of major constituents in water from wells sampled for this study $\ldots . . . . . . . . . . .$.

2. Chemical analyses of selected trace constituents in water from wells sampled for this study . . . . . . . . . . . . .

3. Analyses of stable isotopes, uranium, and radium-226 in water from selected wells sampled for this study - . - . - . -

4. Selected chemical data that show variation of water quality with depth in aquifer layer 1 . . . . . . . . . . . .

5. Selected chemical analyses of water from the Dakota Formation in northwestern Iowa...........-

6. Water-quality data for water samples obtained from piezometers at Schroeder and Kingstrom sites, 


\section{ENGLISH-TO-METRIC UNITS CONVERSION FACTORS AND ABBREVIATIONS}

For readers who prefer to use metric (International System) units rather than the inch-pound units used in this report, conversion factors are listed below.

\begin{tabular}{|c|c|c|}
\hline Multiply inch-pound unit & $B y$ & To obtain metric unit \\
\hline & Length & \\
\hline foot $(\mathrm{ft})$ & 0.3048 & meter $(\mathrm{m})$ \\
\hline mile (mi) & 1.609 & kilometer (km) \\
\hline square mile $\left(\mathrm{mi}^{2}\right)$ & $\begin{array}{r}\text { Area } \\
2.590\end{array}$ & square kilometer $\left(\mathrm{km}^{2}\right)$ \\
\hline cubic foot $\left(\mathrm{ft}^{3}\right)$ & $\begin{array}{l}\text { Volume } \\
0.02832\end{array}$ & cubic meter $\left(\mathbf{m}^{3}\right)$ \\
\hline & Flow & \\
\hline foot per second $(\mathrm{ft} / \mathrm{s})$ & 0.3048 & meter per second $(\mathrm{m} / \mathrm{s})$ \\
\hline foot per year (ft/yr) & 0.3048 & meter per year $(\mathrm{m} / \mathrm{yr})$ \\
\hline $\begin{array}{l}\text { cubic foot per square mile per year } \\
\qquad\left[\left(\mathrm{ft}^{3} / \mathrm{mi}^{2}\right) / \mathrm{yr}\right]\end{array}$ & 0.01093 & $\begin{array}{l}\text { cubic meter per square kilometer } \\
\text { per year }\left[\left(\mathrm{m}^{3} / \mathrm{km}^{2}\right) / \mathrm{yr}\right]\end{array}$ \\
\hline degree Fahrenheit $\left({ }^{\circ} \mathrm{F}\right)$ & $\begin{array}{c}\text { Temperature } \\
0.5556 \\
\left({ }^{\circ} \mathrm{F}-32\right)\end{array}$ & degree Celsius $\left({ }^{\circ} \mathrm{C}\right)$ \\
\hline
\end{tabular}

Sea level: In this report "sea level" refers to the National Geodetic Vertical Datum of 1929 (NGVD of 1929)-a geodetic datum derived from a general adjustment of the first-order level nets of both the United States and Canada, formerly called "Sea Level Datum of 1929."

\section{SYMBOLS AND DEFINITIONS}

$\delta$

$\delta^{13} \mathbf{C}$

$\delta \mathrm{D}$

$\delta^{18} \mathrm{O}$

$\delta^{34} \mathrm{~S}$

$\mu \mathrm{g} / \mathrm{L}$

Eh
Isotopic composition expressed as permil differences in the measured isotopic ratios of sample and standard.

Standard expression of the ratio of the ${ }^{13} \mathrm{C}$ ion with respect to the ${ }^{12} \mathrm{C}$ ion.

Standard expression of the ratio of the ${ }^{2} \mathrm{H}$ ion (deuterium) with respect to the ${ }^{1} \mathrm{H}$ ion.

Standard expression of the ratio of the ${ }^{18} \mathrm{O}$ ion with respect to the ${ }^{16} \mathrm{O}$ ion.

Standard expression of the ratio of the ${ }^{34} \mathrm{~S}$ ion with respect to the ${ }^{32} \mathrm{~S}$ ion.

Micrograms per liter.

Oxidation potential, $\log$ activity of $\mathrm{e}^{1}$. $\mathrm{e}^{1} \quad$ Electron.

(g) Gaseous.

meq/L Milliequivalents per liter.

$\mathrm{mg} / \mathrm{L} \quad$ Milligrams per liter.

$\mathrm{P}_{\mathrm{CO}_{2}} \quad$ Partial pressure of carbon dioxide.

PDB PeeDee belemnite ${ }^{13} \mathrm{C}$ isotopic standard.

pCi/L Picocuries per liter.

pH Negative log activity of $\mathrm{H}^{+}$.

ppm Parts per million.

SI Saturation index.

SMOW Standard Mean Ocean Water ${ }^{18} \mathrm{O}$ and ${ }^{2} \mathrm{H}$ isotopic standard.

(s) Solid. 



\title{
REGIONAL AQUIFER-SYSTEM ANALYSIS-NORTHERN MIDWEST AQUIFER SYSTEM
}

\section{GEOCHEMISTRY OF THE CAMBRIAN-ORDOVICIAN AQUIFER SYSTEM IN THE NORTHERN MIDWEST, UNITED STATES}

\author{
By D.I. Siegel
}

\begin{abstract}
Distributions of solutes in aquifers of Cambrian and Ordovician age were studied in Minnesota, Wisconsin, Iowa, Illinois, northwestern Indiana, and northern Missouri to determine the sources of solutes and the probable chemical mechanisms that control regional variations in water quality. This work is part of the Northern Midwest Regional Aquifer-System Analysis project, whose objective is to describe and model the regional hydrogeology of the CambrianOrdovician aquifer system in the study region. The data base used included more than 3,000 ground-water-quality analyses from all major aquifers, but especially from the St. Peter, Jordan, and Mount Simon Sandstones and their equivalents. Regional variations in the water chemistry of glacial drift and other sedimentary units that overlie the Cambrian-Ordovician aquifer system in recharge areas in Minnesota, Iowa, Wisconsin, and Illinois were also studied, but to a lesser degree.

The most important chemical variation in the aquifer is the change in water type from calcium-sodium-sulfate-bicarbonate water to sodium-calcium-sulfate-bicarbonate and sodium-chloride waters along the longest regional flow path from northwestern Iowa to the Illinois basin. Sodium predominance downgradient from the recharge area is probably related to mechanisms of ion exchange and shalemembrane filtration near the Illinois and Forest City basins.

The most striking aspect of the distribution of dissolved solids and carbon isotopic content of bicarbonate is the increase in concentration and isotopic enrichment from southwestern Wisconsin, southern Minnesota, and northwestern Illinois south toward Missouri. This trend is perpendicular to the present hydraulic gradient that trends from northwestern Iowa southeastward to the Illinois basin. The distribution of dissolved solids defines a "plume" of dilute water having a dissolved-solids concentration of about 500 milligrams per liter, compared with surrounding concentrations more than twice as large. Distribution of the isotopic content of oxygen $\left(\delta^{18} \mathrm{O}\right)$ and hydrogen $(\delta D)$ in water closely parallels that of dissolved solids and shows covariance similar to modern meteoric water. The isotopic contents are more depleted (lighter) toward the south, perpendicular to the direction of current hydraulic gradients. The degree of depletion, compared with the isotopic content of modern recharge water, indicates that the plume and a significant fraction of the ground water in Iowa, northern Missouri, and possibly central Illinois may have originated as recharge during Pleistocene time.

Distributions of dissolved trace constituents in the aquifers probably are related to the proximity to mineralogic sources as well as chemical and hydraulic mechanisms. For example, concentrations of some constituents, such as cadmium and arsenic, are largest in the
\end{abstract}

Manuscript approved for publication November 15, 1985. vicinity of the Dakota Formation in northwestern Iowa. Other constituents, such as beryllium and vanadium, have larger concentrations near the edge of the Forest City basin in southwestern Iowa and northwestern Missouri. Strontium and fluoride concentrations generally increase from north to south, which suggests the input of these trace constituents during the recharge events. However, concentrations of bromide, radium-226, and lithium show distribution patterns similar to the "plume" defined by dissolved solids and isotopes of water, suggesting dilution of concentrations of trace constituents by Pleistocene recharge. Concentrations of other constituents are partly controlled by aquifer temperature, such as silica in south-central Iowa, and solubility controls, such as barium in northeastern Illinois. Additional information on the chemical and mineralogical composition of the aquifer matrix and the isotopically lightest ground water is needed to evaluate the hypothesis of Pleistocene mixing before more quantitative studies can be done to evaluate the different proposed mechanisms that have controlled and modified the water chemistry over time. This study, however, indicates that the ground water in the region is thousands of years old. The study also indicates that the major chemical trends in the aquifers probably are related as much to paleohydrogeologic flow systems during Pleistocene time as to the present flow system, which may postdate the retreat of the last ice sheet about 12,000 years ago.

\section{INTRODUCTION}

Sandstone and dolomite strata of Cambrian and Ordovician age make up much of the sedimentary rocks overlying the Precambrian basement in the northern Midwest and form the major aquifer system of that area. In October 1978, the U.S. Geological Survey began a regional assessment of the CambrianOrdovician aquifer system in that area (Steinhilber and Young, 1979) as part of its national Regional AquiferSystem Analysis (RASA) program (Bennett, 1979). The major goals of the RASA program are to (1) gain an understanding of the hydrogeologic system in each region, including the nature of the hydrogeologic units, ground-water flow system, and chemical quality of the water, and (2) describe the regional interaction of components of the system, especially as affected by largescale withdrawal of ground water. The latter goal is accomplished by constructing digital-computer models that simulate the ground-water flow system. 


\section{PURPOSE AND SCOPE}

This report describes the hydrologic and geochemical mechanisms that cause regional differences in groundwater quality in the northern Midwest. Other regional reports on the aquifer system are being published as chapters of U.S. Geological Survey Professional Paper 1405. They include chapter A, a summary of the Northern Midwest RASA (H.L. Young, U.S. Geological Survey, written commun., 1988), chapter B, which describes the regional hydrogeology and water quality (Young, in press), chapter $\mathrm{C}$, which describes a regional threedimensional ground-water model of the study area (Mandle and Kontis, in press), and chapter E, which describes a detailed three-dimensional ground-water flow model of the Chicago-Milwaukee area (H.L. Young and A.J. MacKenzie, U.S. Geological Survey, written commun., 1988).

The study covers about $161,000 \mathrm{mi}^{2}$ in northern Illinois, northwestern Indiana, Iowa, southeastern Minnesota, northern Missouri, and Wisconsin (fig. 1). The border of the study area delimits either the natural physical or hydrologic boundaries of the aquifer system or places where the aquifers are not used because of poor water quality. The northern boundary, from northwestern Iowa to northeastern Wisconsin, delineates the erosional edge of Cambrian rocks overlying crystalline basement rocks of Precambrian age. The Missouri River is a discharge line and forms the western and southwestern boundary. Beyond the eastern and southeastern boundary in Michigan, Illinois, and Indiana, water in the aquifer is too highly mineralized to be used. As a first approximation, the brine-saltwater interface at about $30,000 \mathrm{mg} / \mathrm{L}$ is assumed to be a minimal-flow boundary.

The primary subject of the study is the Cambrianand Ordovician-age rocks that form the dominant aquifer system in the study area. However, because some wells developed in the Cambrian-Ordovician aquifer system are also open to the overlying carbonate rocks of the Silurian-Devonian aquifer, the latter, although only a minor aquifer regionally, is included in the study.

\section{ACKNOWLEDGMENTS}

I express my appreciation to many U.S. Geological Survey colleagues for their assistance in this study. Special thanks go to E.C. Alexander, Jr., and H.E. Wright, Jr., University of Minnesota, and to E.G. Perry, Jr., Northern Illinois University, for discussions on Pleistocene geology and environmental isotope geochemistry in the study area, and to the many geologists in State agencies with whom I had helpful conversations.

\section{HYDROGEOLOGIC SETTING}

The regional hydrogeology of the CambrianOrdovician aquifer system in the northern Midwest is summarized in Professional Paper 1405-B. The following is a brief regional synopsis of the structural, lithologic, and hydrologic features of the geologic formations in the study area and a description of the vertical discretization of geologic units into layers used in the regional flow model. Detailed accounts of the geology and hydrology of each of the States in the study area can be found in publications of State agencies and the U.S. Geological Survey referenced in Professional Paper 1405-B. The nomenclature used in this report was established for the Northern Midwest RASA (see Professional Paper 1405-B) and does not necessarily coincide with that previously accepted by the U.S. Geological Survey. It follows usage prevalent in the majority of the study area, or usage of a particular State, where appropriate.

The consolidated sedimentary rocks in the northern Midwest consist of sandstone, carbonate, and shale sequences that range in age from Precambrian to Cretaceous (fig. 2). They overlie the eroded surface of the Precambrian basement complex, which consists of crystalline igneous and metamorphic rocks. This basement complex forms the North American craton, the more permanent nucleus of the continent. The widespread sedimentary rocks were deposited in the midcontinental interior by a series of transgressions and regressions of the epeiric Sauk and Tippicanoe seas (King, 1959) as the craton subsided. Irregular subsidence resulted in the formation of the Illinois, Michigan, and Forest City basins, beginning in Early Cambrian time. The major structurally high areas, the Kankakee, Transcontinental, and Wisconsin arches, also began developing during Cambrian time (fig. 2). Cambrian and Ordovician rocks presently crop out or subcrop beneath Pleistocene drift and Holocene sediments in southeastern Minnesota, northeastern Iowa, northern Illinois, and southern Wisconsin. A band of Silurian and Devonian rocks subcrop beneath glacial drift along the trend of the Kankakee arch between Michigan and Illinois, along the eastern part of Wisconsin, and in northeastern Iowa (fig. 2). Mississippian and younger rocks border the major sedimentary basins and are present southwest and east of the Silurian rocks.

The Cambrian and Ordovician rocks in the northern Midwest have long been divided into rock-stratigraphic units on the basis of lithology and lateral continuity. For this study, the units were grouped into five aquifer layers and four confining layers on the basis of their hydrologic properties. Figure 3 is a generalized geologic 


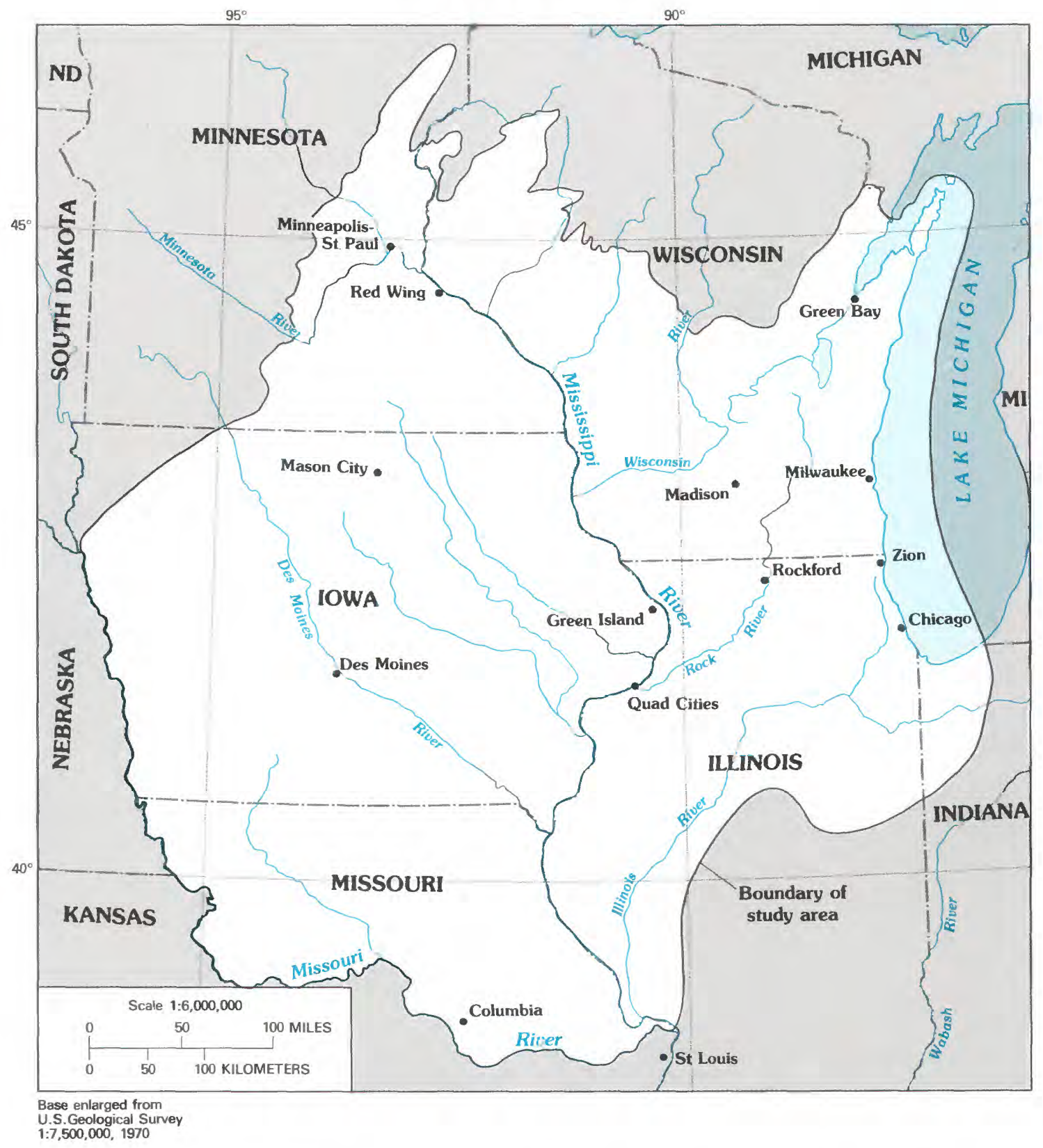

Figure 1.-Location and general features of the Northern Midwest Regional Aquifer-System Analysis area.

section from Missouri to Wisconsin, which shows this hydrogeologic grouping. The first and deepest hydrogeologic unit, the Mount Simon aquifer (aquifer layer 1 ), is composed mainly of the Mount Simon Sandstone and its equivalents. This basal sandstone rests on the Precambrian basement complex in much of the study area, but on older Precambrian red clastic rocks in Minnesota and western Wisconsin. The latter are included in aquifer layer 1 . The Mount Simon Sand- stone is a marine, fine- to coarse-grained conglomeratic sandstone and ranges in thickness from less than $100 \mathrm{ft}$ in Minnesota and Wisconsin to more than 2,500 ft in the northern part of the Illinois basin. In the northern part of the area it is overlain by shale, dolomitic sandstone, siltstone, and dolomite of the Eau Claire Formation, which constitutes a regional confining unit. The Eau Claire is predominantly a fine-grained sandstone in Wisconsin but has varying amounts of shale. The Eau 


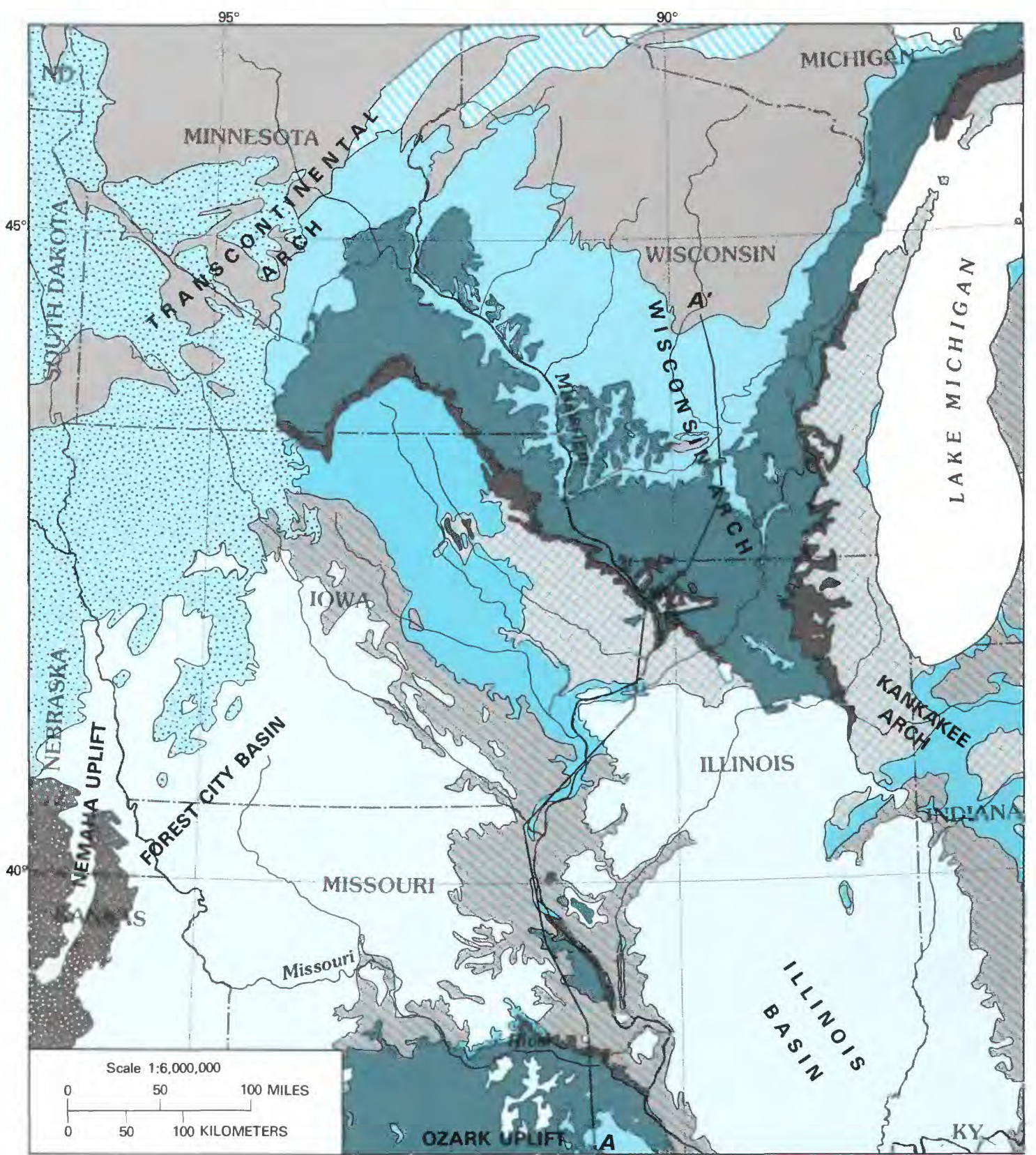

Base enlarged from U.S.Geological Survey
$1: 7,500,000,1970$

\section{EXPLANATION}

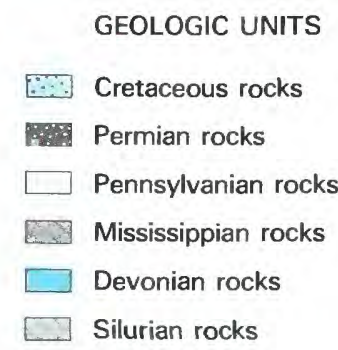

Ordovician Maquoketa Shale

Ordovician rocks older than Maquoketa Shale

Cambrian rocks

$\square$ Precambrian sandstone

Precambrian crystalline rocks - CONTACT

\section{$\boldsymbol{A}-\boldsymbol{A}^{\prime}$ LINE OF GEOLOGIC SECTION Section shown in figure 3}

FIGURE 2.-General bedrock geology of the northern Midwest. (Modified from Young, in press.) 


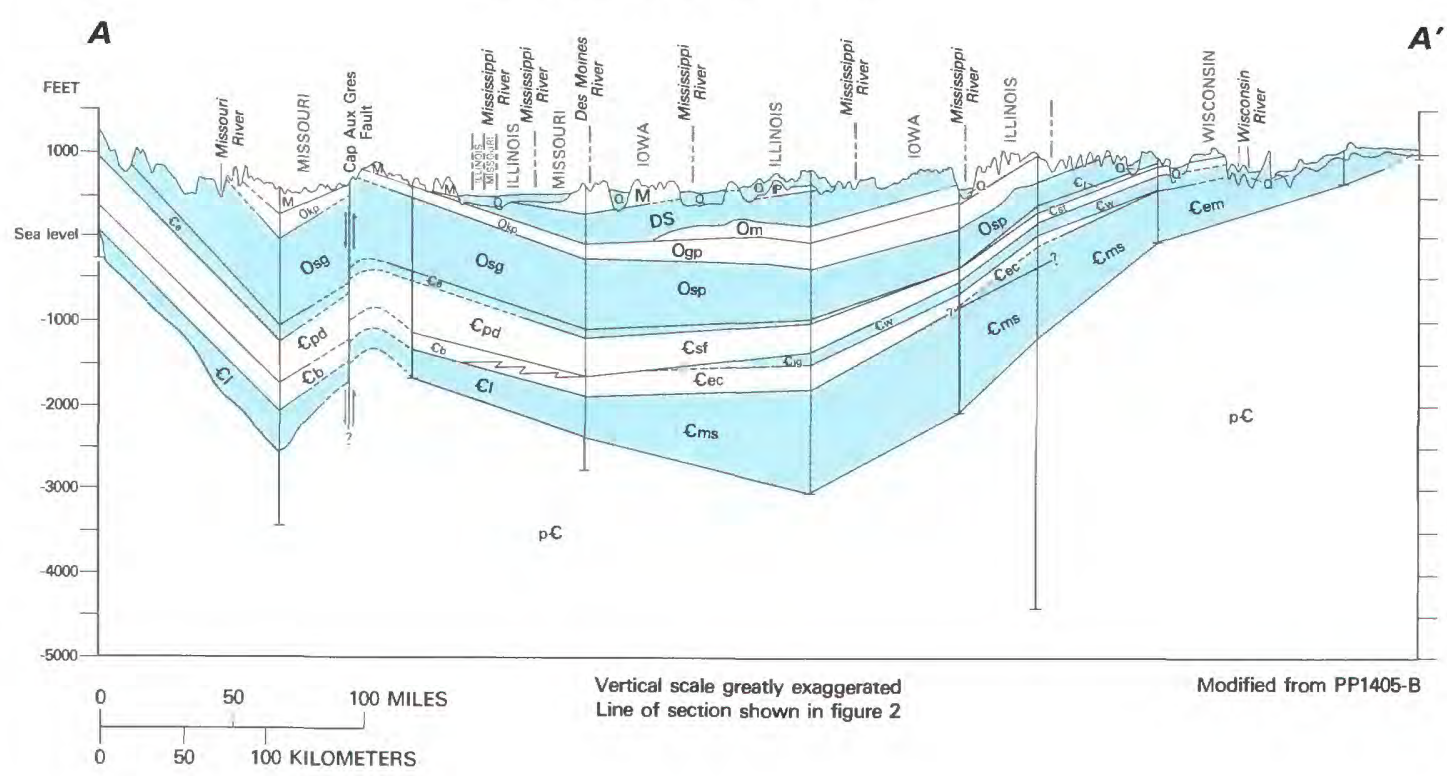

EXPLANATION

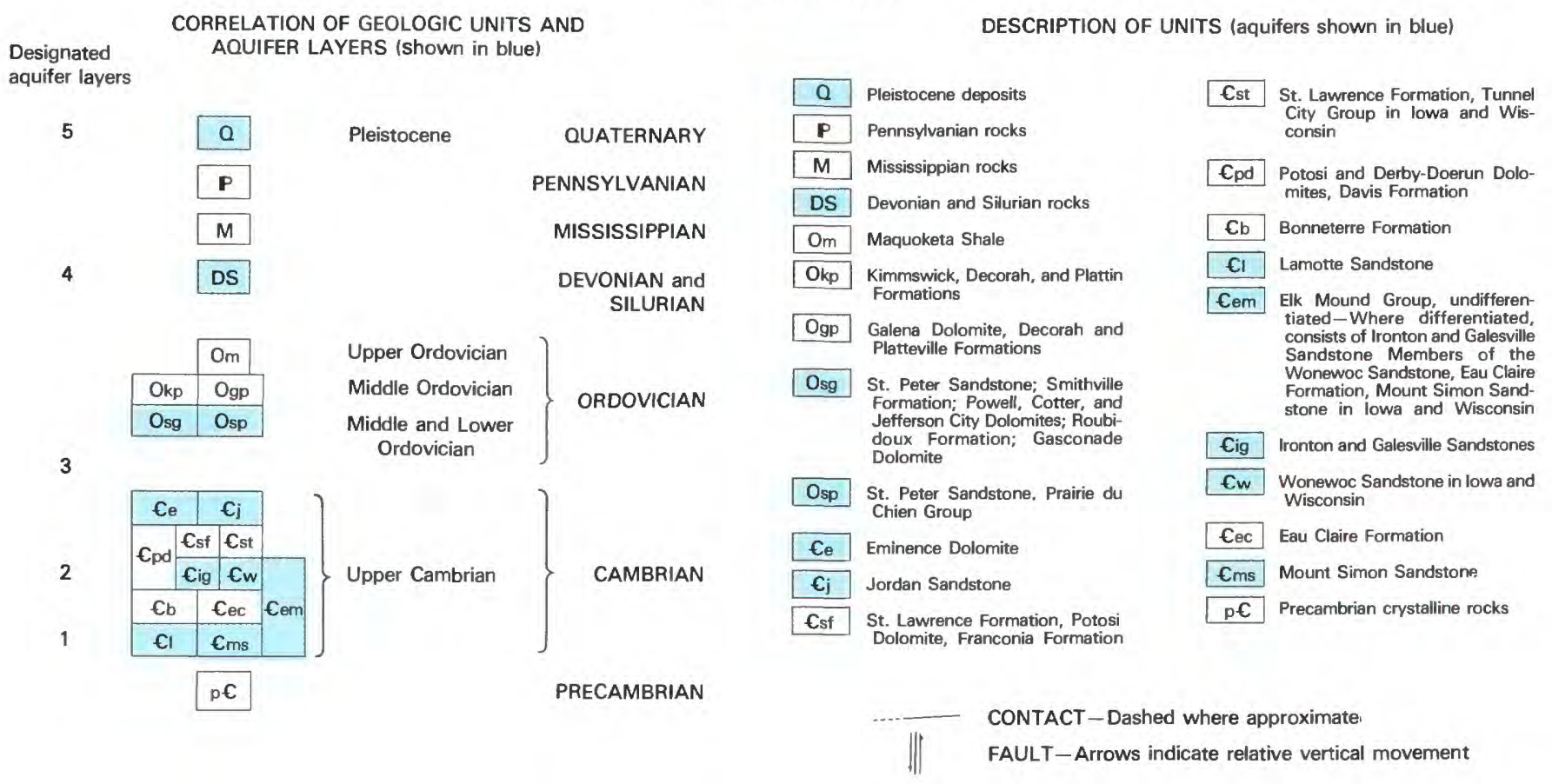

Figure 3.-Geologic section from Missouri to Wisconsin. (Modified from Young, in press.)

Claire is not strongly confining in much of Wisconsin and is hydrologically connected with the underlying Mount Simon Sandstone and the overlying Ironton and Galesville Sandstones, except toward the south where the upper part becomes more shaly. To the south in Missouri, the Eau Claire grades into dolomite of the
Bonneterre Formation. In northern Illinois, the lower part of the Eau Claire, the Elmhurst Sandstone Member, is included in aquifer layer 1 , which is locally termed the "basal sandstone aquifer." In south-central Minnesota, the Eau Claire Formation consists, in part, of glauconitic "greensands." 
Aquifer layer 2, the Ironton-Galesville aquifer, is the combined Ironton and Galesville Sandstones and, in Iowa and Wisconsin, the equivalent Wonewoc Formation. It is generally less than $100 \mathrm{ft}$ thick but exceeds $200 \mathrm{ft}$ in the Illinois basin. It consists of calcareous to dolomitic sandstone in Minnesota, Wisconsin, and northern Illinois. The aquifer layer is absent in southern Illinois and is thin or absent and grades into carbonate rocks of the lower part of the Davis Formation in southwestern Iowa and Missouri. Shaly sandstones of the Franconia Formation and limestone and dolomite of the St. Lawrence Formation overlie and confine the Ironton-Galesville aquifer in the north. The southern equivalent of the St. Lawrence-Franconia confining unit is the upper Davis Formation through Potosi Dolomite interval.

The composition of the third aquifer layer varies with its geographic location. In most of the study area it consists of, from oldest to youngest, the Jordan Sandstone, the overlying Prairie du Chien Group, and the St. Peter Sandstone. In Missouri, the Gasconade DolomiteSmithville Formation sequence is a general equivalent and replaces the Prairie du Chien Group. Also, the Jordan Sandstone is replaced by the Eminence Dolomite in Missouri and all but the extreme northwestern part of Illinois. These formations are generally in hydrologic connection. They are treated as a single unit because fractures commonly penetrate through the Prairie du Chien Group.

The Jordan Sandstone is a coarse- to medium-grained orthoquartzite to dolomitic sandstone in Minnesota, Wisconsin, and Iowa, grading into sandy dolomite and dolomite in southern Iowa, northern Missouri, and all but the extreme northwestern part of Illinois. The Prairie du Chien Group consists of fossiliferous dolomite and limestone interbedded with thin, discontinuous beds of sandstone, siltstone, and shale. Aquifer layers 1 and 3 generally range from 200 to $600 \mathrm{ft}$ in thickness in the northern half of the study area but thicken to more than $1,500 \mathrm{ft}$ in the Illinois basin. The St. Peter Sandstone is a laterally persistent clean and friable orthoquartzite, generally 100 to $200 \mathrm{ft}$ thick except locally in northern Illinois, where thickness exceeds $700 \mathrm{ft}$ upon pre-St. Peter karstic topography.

The Maquoketa Shale forms a very effective confining unit above aquifer layer 3 over much of the study area. The Maquoketa consists of thick pyritic shales except in western Iowa and Minnesota, where the shales grade into interbedded dolomitic limestones and shaly dolomites that provide a hydraulic connection with overlying and underlying carbonates. The shaly dolomites, which make up the Galena Dolomite and Decorah and Platteville Formations or equivalents, are gen- erally of low permeability where overlain by the Maquoketa and are included as part of the confining unit. The base of the confining unit is the Glenwood Formation, which consists generally of shale and silty, shaly sandstone. Extensive phosphatic beds are present within the Maquoketa in Iowa. The CambrianOrdovician aquifer system is further confined by thick sequences of younger Paleozoic rocks south of the outcrop of the Maquoketa Shale.

Aquifer layer 4 consists of the carbonate rocks of the Silurian through Middle Devonian and is termed the Silurian-Devonian aquifer for this study. The rocks are dominantly thick- to thinly bedded dolomites, limestones, and shales that are hydraulically connected by fractures. Where not eroded, they generally range in thickness from 200 to $500 \mathrm{ft}$, but they are more than $1,000 \mathrm{ft}$ thick in the Illinois basin. The excellent confinement of the Maquoketa Shale, which separates aquifer layer 4 from aquifer layer 3 , limits the potential of water in aquifer layer 4 to affect the chemistry of water in the Cambrian-Ordovician aquifer system. However, the opposite may be true where the Maquoketa is mainly a fractured carbonate. The very thick sequence of younger consolidated rocks from the Upper Devonian through the Pennsylvanian contains little aquifer material and, for the purposes of this study, is considered to be a confining unit between aquifer layers 4 and 5. In Iowa, the Mississippian is classified as a separate aquifer (Horick and Steinhilber, 1973).

Aquifer layer 5 consists of the combined Holocene surficial deposits, Pleistocene glacial drift, or Cretaceous rocks that form the land surface over most of the study area. This layer directly overlies the units of the Cambrian-Ordovician aquifer system in much of the Cambrian-Ordovician outcrop areas in Minnesota, Iowa, Wisconsin, and Illinois. Most drift is calcareous because of carbonate minerals derived from the glacial erosion of Paleozoic limestones and dolomites in Manitoba and Michigan and within the study area. Except for the Driftless Area of southwestern Wisconsin and adjacent small areas in Illinois and Iowa, the entire study area was glaciated during the Pleistocene. Cretaceous rocks that overlie the Cambrian and Ordovician rocks in western Minnesota and Iowa consist of varicolored marine shales, siltstones, and lignitic sandstones of the Dakota Formation, which commonly contains disseminated pyrite in its basal part.

The ground-water reservoir is recharged by infiltration of precipitation through the soil into the underlying rock. Because glacial deposits are the surficial rocks in most of the northern Midwest, they receive most of the initial recharge. Aquifer layers 1 through 4 also are recharged by infiltration of precipitation where they crop out at the land surface, such as in the Driftless 
Area. These aquifers also receive recharge by vertical seepage across confining beds, where they subcrop beneath aquifer layer 5 and where they are penetrated by buried bedrock valleys eroded by glacial meltwater streams during Pleistocene time. Both field observation and steady-state simulation of the ground-water flow system (Mandle and Kontis, in press) indicate that vertical head gradients in the Cambrian-Ordovician aquifers (aquifer layers 1 through 3) are generally upward where overlain by the Maquoketa Shale in Iowa, Illinois, and Wisconsin (fig. 4). Vertical head gradients are downward in the Cambrian-Ordovician outcrop areas in much of south-central Minnesota, southcentral Wisconsin, and northern Iowa.

Ground water flows from topographically high recharge areas to low discharge areas. Most of the ground water in aquifer layer 5 moves within local flow systems of a few miles in length and discharges to small first- and second-order tributaries of the major rivers. Ground-water movement in the unconfined parts of the Cambrian-Ordovician aquifer system is similar, but the flow systems are larger and discharge is toward the major river valleys. Figure 5 is a representation of the original predevelopment potentiometric surface of aquifer layer 3 , for which the most data are available, and is generally representative of the predevelopment potentiometric heads in the lower aquifer layers. The more localized flow systems in the unconfined areas are shown by the topographic control and steeper gradient of the contours there. In the confined areas, ground water moves toward the Illinois and Michigan basins but can discharge only as upward leakage across confining units. Thus the rate of lateral flow into the basins is greatly decreased. The longest flow paths in the aquifer system (more than $300 \mathrm{mi}$ ) extend from recharge areas in northwestern Iowa to the center of the Illinois basin (fig. 5). Shorter flow paths (less than $50 \mathrm{mi}$ ) in the northern part of the area extend from recharge areas: in central Minnesota to the Minnesota River; in central Wisconsin, central Minnesota, northeastern Iowa, and northwestern Illinois to the Mississippi River; and in eastern Wisconsin and northeastern Illinois toward Lake Michigan. Penetration of aquifer layers by the Mississippi River valley during the Pleistocene causes the flow system in the northern part of the study area to have shorter flow paths. This effect of the Mississippi River is most pronounced in aquifer layers 3 and 4 and is less pronounced in layers 1 and 2. For example, flow in layer 3 discharges to the Mississippi River as far south as about $50 \mathrm{mi}$ south of the Wisconsin-Illinois State line, but the direct influence of the river on aquifer layer 1 extends only as far as the Minnesota-Iowa State line. Aquifer layer 4 discharges toward the Mississippi River downstream from northeastern Iowa.

\section{GEOCHEMISTRY}

\section{METHODS OF INVESTIGATION}

The interpretation of regional ground-water quality is based on a synthesis of more than 3,000 chemical analyses of ground water available from the U.S. Geological Survey WATSTORE (Water Data Storage and Retrieval System) data base, publications of State and Federal agencies, and scientific journals. Published descriptions of the water chemistry of parts of the Cambrian-Ordovician aquifer system were reviewed, particularly in the following references (grouped by State): Minnesota-Winter (1974), Norvitch and others (1973), and Maderak (1965); Wisconsin-Kammerer (1981), Holt and Skinner (1973), and Ryling (1961); Iowa-Horick and Steinhilber (1978); Missouri-Feder (1979) and Gann and others (1971, 1973); and IllinoisLarson (1963), Gibb and O'Hearn (1980), and Schicht and others (1976). Description and analyses of brines in Cambrian-Ordovician aquifer units were obtained from Meents and others (1952), Graf and others $(1965,1966)$, Bond (1972), and the files of the Indiana and Michigan Geological Surveys and the Illinois State Water Survey.

Mean concentrations are used where multiple analyses are available. In general, analyses that did not balance electrochemically within 5 percent were deleted from the data base. Some partial analyses of brines include data for only dissolved solids and chloride, but these analyses were used to complete the areal distribution of dissolved solids along the southeastern boundary of the study area. Thus, the lines of equal concentration there should be considered approximate.

One hundred and sixty-four ground-water samples were collected for the study during the period 1980-82 to determine the concentrations of trace constituents and radiochemical species as well as stable isotope ratios. Seventy-five samples were collected to determine the isotopic composition of oxygen and hydrogen in the ground water and of carbon in bicarbonate. The isotopic composition of sulfur in sulfate was determined for selected samples. Field $\mathrm{pH}$, alkalinity, and temperature of the water were measured at critical sample locations along ground-water flow paths to enable calculation of chemical species at equilibrium. Analyses were made using methods described in American Public Health Association (1980) and Skougstad and others (1979). Isotopic composition of water, carbon in inorganic carbon, and sulfur in sulfate was determined by standard methods. By convention, the isotopic variations are expressed as $\pm \delta$ values in parts per thousand (permil) differences in the measured isotopic ratios in a sample and in appropriate standards: Standard Mean Ocean Water (SMOW) for oxygen $\left(\delta^{18} \mathrm{O}\right)$ and 


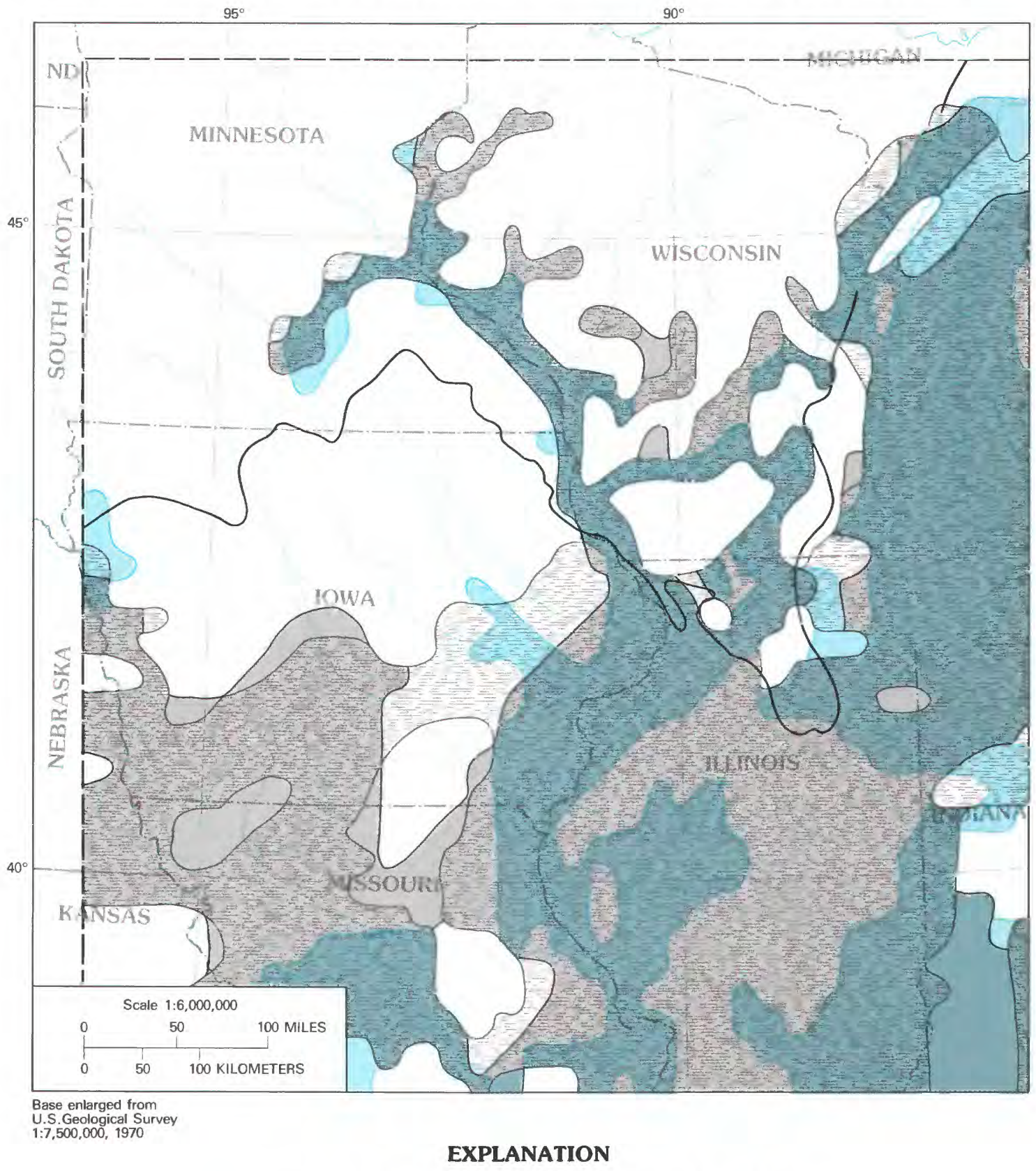

SIMULATED DISCHARGE AREA-Shows area where the groundwater flow model indicates upward flow from the aquifer layer for predevelopment conditions

Aquifer layer 3

Aquifer layer 2

Aquifer layer 1

NORTHERN BOUNDARY OF MAQUOKETA SHALE BOUNDARY OF GROUND-WATER FLOW MODEL

Figure 4.-Simulated predevelopment discharge areas for aquifer layers 1, 2, and 3. (Modified from Mandle and Kontis, in press.) 


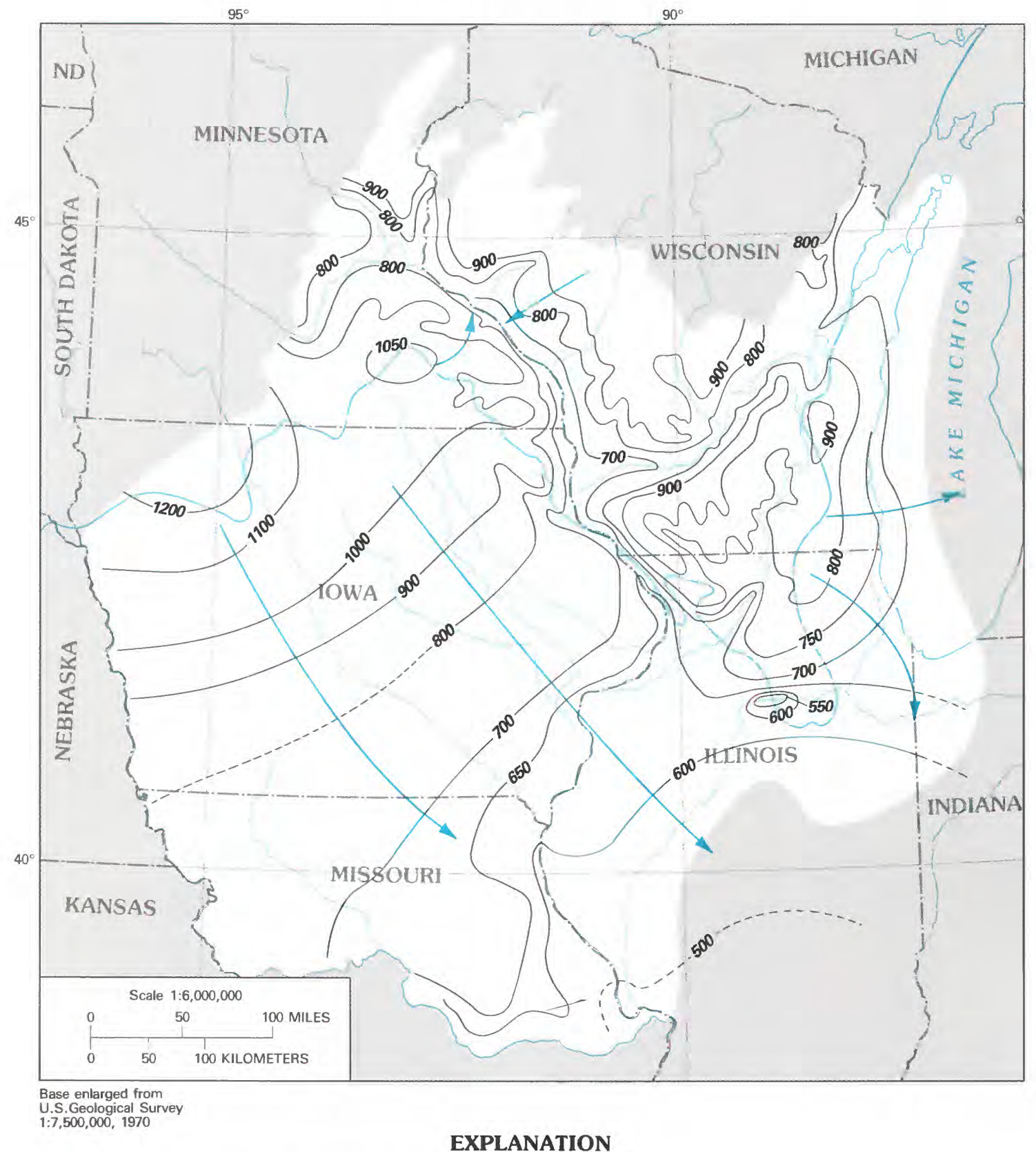

-600 _. POTENTIOMETRIC CONTOUR-Shows altitude of predevelopment potentiometric surface for aquifer layer 3 . Dashed where approximate. Interval, in feet, is variable. Datum is sea level

$\longleftarrow$ DIRECTION OF GROUND-WATER MOVEMENT NORTHERN BOUNDARY OF MAQUOKETA SHALE

FiguRE 5.-Approximate predevelopment potentiometric surface for aquifer layer 3. (Modified from Young, in press.) 
hydrogen $(\delta \mathrm{D})$ in water, Canyon Diablo troilite for sulfur $\left(\delta^{34} \mathrm{~S}\right)$, and PeeDee belemnite (PDB standard) for carbon $\left(\delta^{13} \mathrm{C}\right)$. Results of the analyses for the study are given in tables 1, 2, and 3 (at the end of the report). Figure 6 shows the locations of the wells in aquifer layers 1,3 , and 5 sampled for this study and the locations of selected wells in aquifer layers 1 and 3 with WATSTORE and published analyses. Data distribution for aquifer layer 5 was dense throughout the recharge areas of Wisconsin, Minnesota, Iowa, and Illinois; consequently, the locations of only new data for this aquifer layer are shown in figure 6 . In subsequent figures that show areal distribution of solutes, only locations of data collected during this study are plotted.

Maps showing the areal distribution of solutes were derived from a composite of data from aquifer layers 1 and 3 , for which there is significant regional coverage. It is recognized that because the lithologies of these layers are different, the chemistry may be different. However, the composited data are used as a first approximation in describing the regional chemical patterns for the following reasons:

1. The chemical quality of ground water in aquifer layers 1 and 3 is essentially the same in outcrop areas in Minnesota, Wisconsin, Illinois, and Iowa.

2. In the major confined areas in Iowa, Missouri, Illinois, and eastern Wisconsin, all but a few data points are from aquifer layer 3 (fig. 6).

The maps of areal solute distribution in this report, therefore, represent mainly aquifer layer 3 in the confined part of the aquifer and aquifer layers 1, 2, and 3 in outcrop areas. Where data distribution was dense, maps of concentrations of dissolved solids and particular ions were prepared, in part, by data-management techniques described by Kontis and Mandle (1980).

The detailed evaluation of the water quality of the Cambrian-Ordovician aquifer system was restricted to aquifer layers 3 and 5 , for which the areal distribution of data was considered sufficient to evaluate regional trends and variations in concentrations of major dissolved constituents. In most of Wisconsin and northcentral Illinois, aquifer layers 1, 2, and 3 are unconfined and are hydraulically connected; thus water quality in those aquifer layers is probably similar. All statistical calculations were made using computer methods of the Statistical Analysis System (SAS Institute, Inc., 1979).

\section{DISSOLVED SOLIDS}

The chemical quality of the water in the CambrianOrdovician aquifer system varies widely from recharge areas to discharge areas. Dissolved-solids concentrations range from less than $200 \mathrm{mg} / \mathrm{L}$ in the outcrop areas in Wisconsin and southeastern Minnesota to more than $200,000 \mathrm{mg} / \mathrm{L}$ in the Illinois basin. The $500-\mathrm{mg} / \mathrm{L}$ line of equal dissolved solids (isopleth) in figure 7 roughly outlines the extent of the predominantly unconfined flow systems in the northern half of the study area. The $500-\mathrm{mg} / \mathrm{L}$ line also is approximately parallel to the outcrop pattern of the Maquoketa Shale in Illinois and Wisconsin, the major confining unit between the Cambrian-Ordovician aquifer system and the overlying units. Dissolved solids generally increase in the direction of the hydraulic gradient.

In Iowa, the $500-\mathrm{mg} / \mathrm{L}$ line shows a plume-shaped zone of fresher water trending from the northeast to the south-southwest across the Maquoketa Shale outcrop (figs. 2, 7). In both Iowa and Missouri, the gradient toward increasing dissolved solids (fig. 7) varies but is generally perpendicular to the direction of the hydraulic gradient shown in figure 5 . For example, along the flow path that is approximately coincident with geochemical section $A-A^{\prime}$ (fig. 6), dissolved solids decrease from $2,400 \mathrm{mg} / \mathrm{L}$ at well 59 (Hibbing, Iowa) to $440 \mathrm{mg} / \mathrm{L}$ at well 144 (Altoona, Iowa) in the south-central part of the State. Dissolved solids increase southeast of Altoona to more than $100,000 \mathrm{mg} / \mathrm{L}$ in the Illinois basin (fig. 7). Dissolved solids normally increase along the hydraulic gradient because as the residence time of water in the aquifer increases, the water has a longer period of interaction with the rock minerals (Chebotarev, 1955; Back and Hanshaw, 1965). The discordance of increasing dissolved-solids distribution with the hydraulic gradient in the central part of the study area is an abnormal occurrence and poses a major geochemical anomaly that is examined and discussed in a later section, "Hypothetical Geochemical Models."

\section{CHEMICAL CLASSIFICATION}

Water chemistry in the aquifer system was classified by calculating percentages of equivalents per liter for major cations and anions. Maps were prepared showing the areal distribution of water types according to the method described by Back (1966). These maps were used to relate water chemistry to lithologic changes in aquifers and to evaluate possible geochemical and hydrologic processes that control the evolution of water chemistry along and across the hydraulic gradients.

A wide range of water types is present in the Cambrian-Ordovician aquifer system. Water recharged to the system through aquifer layer 5 ranges from a $\mathrm{Ca}-\mathrm{Mg}-\mathrm{HCO}_{3}$ type in the northern part of the area to a $\mathrm{Ca}-\mathrm{Na}-\mathrm{SO}_{4}-\mathrm{HCO}_{3}$ type in northwestern Iowa and southwestern Minnesota (fig. 8). Dissolved solids in aquifer layer 5 range from less than 300 to more than 2,000 $\mathrm{mg} / \mathrm{L}$ in Minnesota, Wisconsin, and northwestern Iowa.

Water chemistry in the Cambrian-Ordovician aquifer system in recharge areas in Minnesota, Wisconsin, Illinois, and Iowa is very similar to that in the overlying 


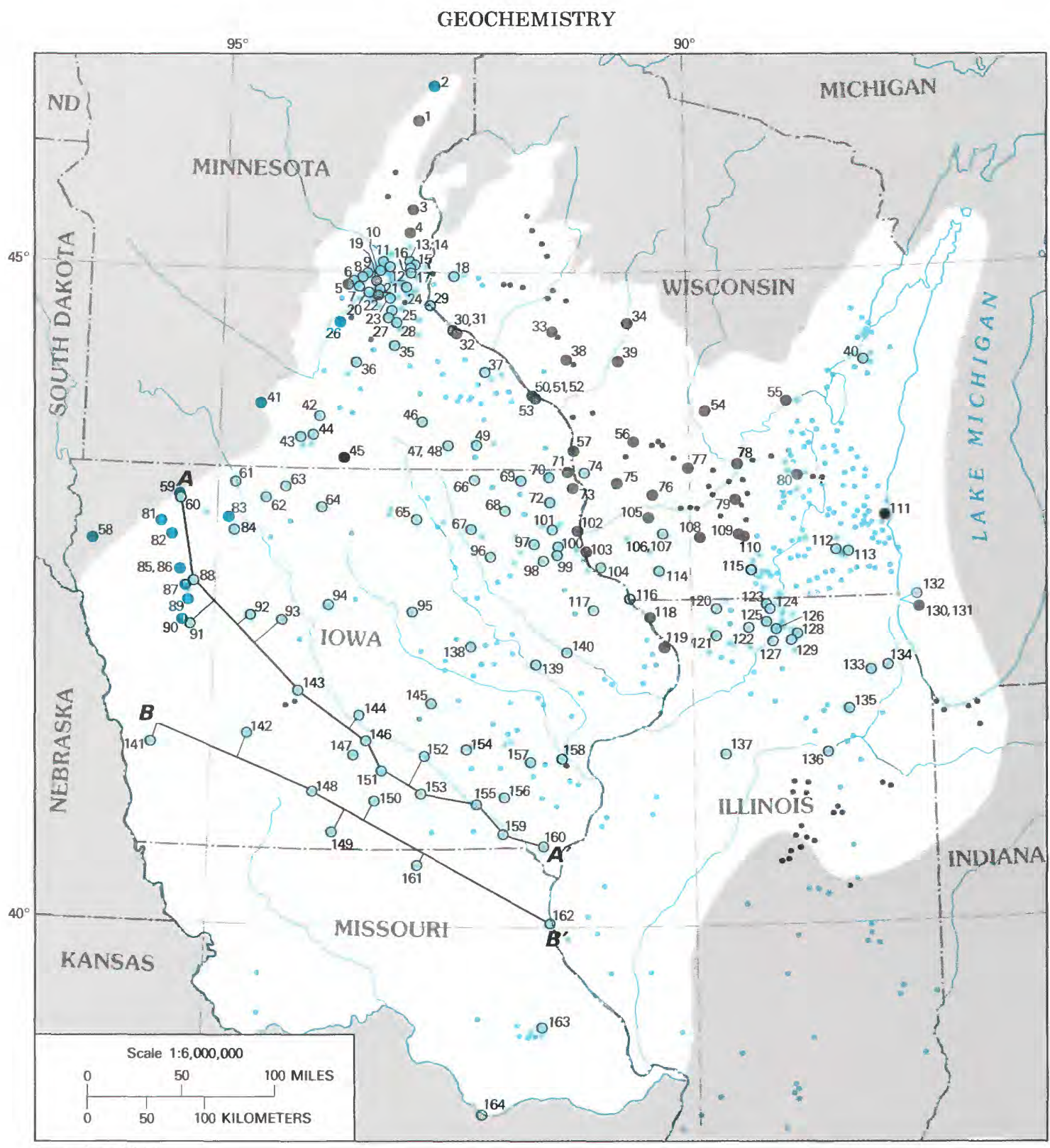

Base enlarged from $1: 7,500,000,1970$

\section{EXPLANATION}

WELL WITH CHEMICAL ANALYSIS-Sample collected during this study. Numbers refer to tables 1, 2 and 3

- Mount Simon aquifer

$0^{65}$ St. Peter-Prairie du Chien-Jordan aquifer

- 45 Silurian-Devonian aquifer

Drift or Cretaceous aquifer

WATSTORE and published data

Mount Simon aquifer

St. Peter-Prairie du Chien-Jordan aquifer

B-B LINE OF GEOCHEMICAL SECTION-Sections shown in figures 17 and 18

Figure 6. - Location of wells with water-quality analyses and location of geochemical sections $A-A^{\prime}$ and $B-B^{\prime}$. 


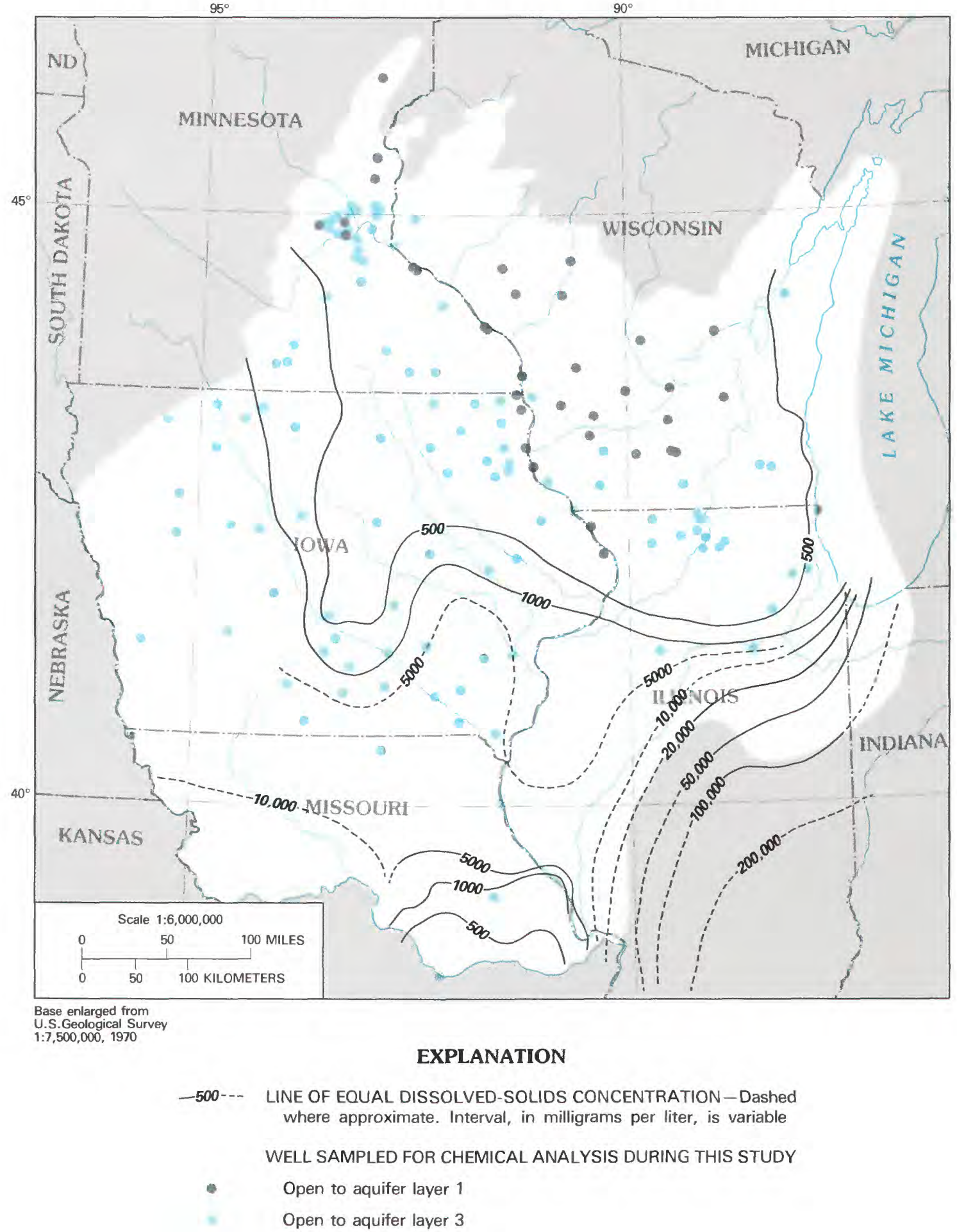

Figure 7.-Dissolved-solids distribution in aquifer layers 1 and 3. (Modified from Young, in press.) 


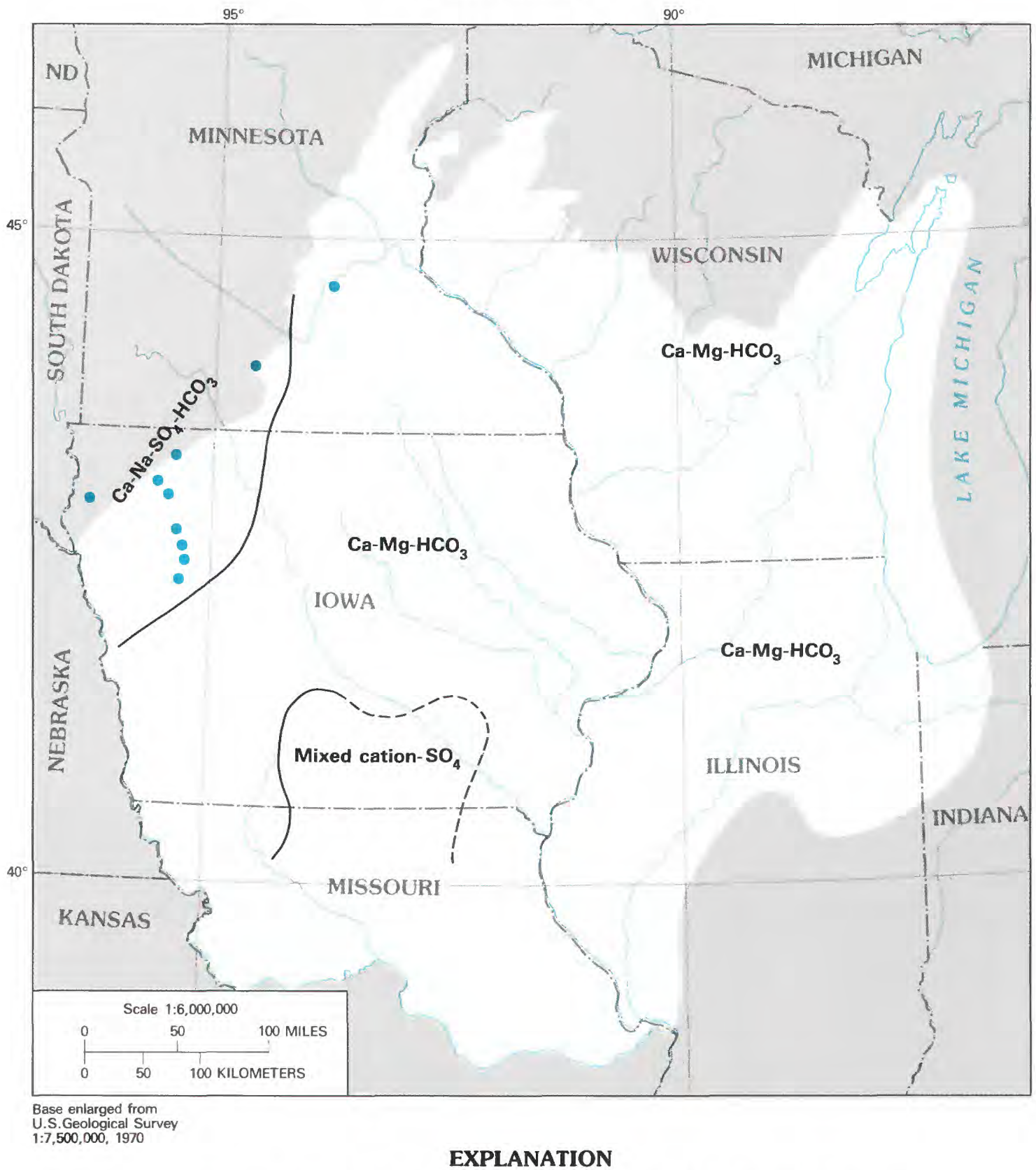

- HYDROCHEMICAL FACIES ZONE BOUNDARY-Dashed where approximate

- WELL SAMPLED FOR CHEMICAL ANALYSIS DURING THIS STUDY Open to aquifer layer 5

FIGURE 8.-Hydrochemical facies of ground water in aquifer layer 5. 


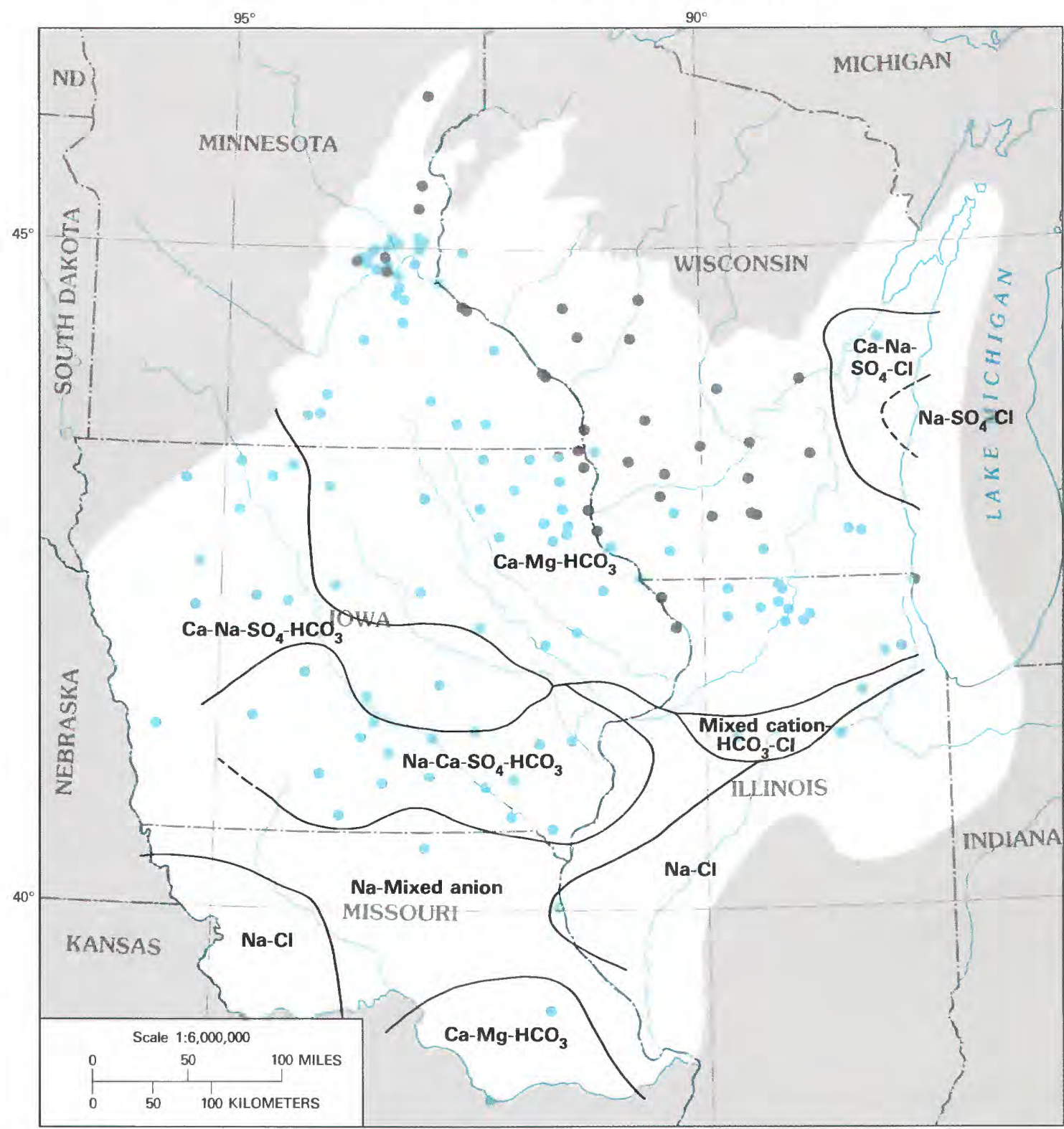

Base enlarged from $1: 7,500,000,1970$
.

\section{EXPLANATION}

HYDROCHEMICAL FACIES ZONE BOUNDARY-Dashed where approximate

WELL SAMPLED FOR CHEMICAL ANALYSIS DURING THIS STUDY

- Open to aquifer layer 1

Open to aquifer layer 3

Figure 9.-Hydrochemical facies of ground water in aquifer layers 1 and 3. 
aquifer layer 5 . Water in both aquifer layers 1 and 3 in the northern part of the study area is a Ca- $\mathrm{Mg}-\mathrm{HCO}_{3}$ type, but water in northwestern Iowa and southwestern Minnesota is a Ca-Na- $\mathrm{SO}_{4}-\mathrm{HCO}_{3}$ type (fig. 9).

The most pronounced geochemical changes occur in the confined parts of the aquifer system. Along flow paths confined by the Maquoketa Shale from eastern Wisconsin east toward the Michigan basin, water chemistry changes from $\mathrm{Ca}-\mathrm{Mg}-\mathrm{HCO}_{3}$ to $\mathrm{Ca}-\mathrm{Na}-\mathrm{SO}_{4}$ and $\mathrm{Na}-\mathrm{Cl}-\mathrm{SO}_{4}$ waters, a transition to the $\mathrm{Ca}-\mathrm{SO}_{4}$ and $\mathrm{Ca}-\mathrm{Cl}_{2}$ types of brines in the Michigan basin (fig. 9). From northern Illinois to central Illinois also, the water changes from a $\mathrm{Ca}-\mathrm{Mg}-\mathrm{HCO}_{3}$ type to a $\mathrm{Na}-\mathrm{Cl}$ type similar to the brines in the Illinois basin.

The largest variability in water chemistry occurs along confined flow paths in the aquifer system from northwestern Iowa to central Illinois. Water type evolves along the hydraulic gradient to the Illinois basin from the $\mathrm{Ca}-\mathrm{Na}-\mathrm{SO}_{4}-\mathrm{HCO}_{3}$ water that typically is present in the Dakota Formation and overlying drift of aquifer layer 5 to $\mathrm{Na}-\mathrm{Ca}-\mathrm{SO}_{4}-\mathrm{HCO}_{3}, \mathrm{Na}$-anion (no dominant anion), and $\mathrm{Na}-\mathrm{Cl}$ water. This change occurs in aquifer layer 3 even though the dissolved-solids concentration decreases along the central part of the flow path. South of the $\mathrm{Na}-\mathrm{Ca}-\mathrm{SO}_{4}-\mathrm{HCO}_{3}$ facies in southcentral Iowa, the water is of either the $\mathrm{Na}-\mathrm{Cl}$ or the Na-anion type.

Few generalizations can be made about variations in water types in aquifer layers 1 and 2 or with depth in individual aquifer layers because of the scant data on the areal distribution of the major solutes in aquifer layers 1,2 , and 4 . Saline water is present in aquifer layer 1 at several locations along the Mississippi River valley. Chemical data from municipal wells in aquifer layer 1 at Red Wing, Minn. (fig. 1), indicate that the water type changes from $\mathrm{Ca}-\mathrm{Mg}-\mathrm{HCO}_{3}$ to $\mathrm{Na}-\mathrm{Cl}$ at depth (table 4). This change in water quality with depth can occur with increases of dissolved solids from less than 500 to several thousand milligrams per liter (Hall and others, 1911; Thiel, 1944). A similar increase in dissolved solids and change in water type in aquifer layer 1 occurs near Lake Michigan, where high salinity makes aquifer layer 1 nonpotable in some places. Samples collected from aquifer layer 1 in a deep test well drilled for this study at Zion, Ill. (fig. 1), illustrate the increase in salinity with depth (table 4). This increase in salinity is also found in aquifer layer 1 within the Illinois basin in central Illinois and eastern Indiana (Meents and others, 1952; R.J. Shedlock, U.S. Geological Survey, written commun., 1983). These data plus scant data from wells in south-central Iowa (fig. 6) suggest that the $\mathrm{Na}-\mathrm{Cl}$ water type in Iowa in aquifer layer 1 may be present much farther up the hydraulic gradient than in aquifer layer 3.
TABLE 4.-Selected chemical data that show variation of water quality with depth in aquifer layer 1

[Results in milligrams per liter, except as indicated. Map number is location in figure 6 ]

\begin{tabular}{|c|c|c|c|c|}
\hline & \multicolumn{4}{|c|}{ Well name } \\
\hline & $\begin{array}{l}\text { USGS } \\
\text { Zion, }\end{array}$ & $\begin{array}{l}\text { est well } \\
\text { slinois }\end{array}$ & $\begin{array}{c}\text { Red Wing } \\
\text { no. } 1 \\
\text { west, } \\
\text { Minne- } \\
\text { sota }\end{array}$ & $\begin{array}{c}\text { Red Wing } \\
\text { no. } 3 \text {, } \\
\text { Minne- } \\
\text { sota }\end{array}$ \\
\hline Map number & 130 & 131 & 30 & 32 \\
\hline Date of collection & $12-10-80$ & $1-14-81$ & $2-12-80$ & $2-13-80$ \\
\hline $\begin{array}{l}\text { Field pH (stand- } \\
\text { ard units) }\end{array}$ & 7.2 & - & 7.4 & 7.4 \\
\hline $\begin{array}{l}\text { Dissolved solids, } \\
\text { residue on } \\
\text { evaporation }\end{array}$ & 2,800 & 58,300 & 410 & 1,110 \\
\hline Calcium, Ca & 311 & 1,000 & 64 & 80 \\
\hline Magnesium, $\mathrm{Mg}$ & 39 & 930 & 27 & 44 \\
\hline Sodium, $\mathrm{Na}$ & 440 & 15,000 & 53 & 250 \\
\hline Potassium, K & 16 & 270 & 6.8 & 7.9 \\
\hline Sulfate, $\mathrm{SO}_{4}$ & 1,300 & 1,400 & 34 & 36 \\
\hline Chloride, $\mathrm{Cl}$ & 370 & 37,000 & 80 & 550 \\
\hline $\begin{array}{l}\text { Interval sampled } \\
\text { (feet below } \\
\text { land surface) }\end{array}$ & $1,775-1,935$ & $3,120-3,475$ & $350-630$ & $385-770$ \\
\hline
\end{tabular}

\section{GEOCHEMICAL PROCESSES}

CALCIUM-MAGNESIUM-BICARBONATE WATER TYPE

The major geochemical and hydrologic processes that cause the changes in dissolved-solids concentrations and water types in the Cambrian-Ordovician aquifer system can be evaluated at different levels of complexity. Qualitatively, the $\mathrm{Ca}-\mathrm{Mg}-\mathrm{HCO}_{3}$ water in all layers probably reflects the dissolution of calcite $\left(\mathrm{CaCO}_{3}\right)$ and dolomite $\left[\mathrm{CaMg}\left(\mathrm{CO}_{3}\right)_{2}\right]$ in the aquifer matrix and overlying drift. The chemical reactions involved in the dissolution of carbonate minerals are a combination of hydrolysis and dissociation. The major source of acidity in the northern part of the study area is probably carbon dioxide in the atmosphere and soil. The pertinent reactions for the dissolution of calcite by carbonic acid may be expressed by

$$
\begin{aligned}
& \mathrm{CO}_{2(\mathrm{~g})}+\mathrm{H}_{2} \mathrm{O}=\mathrm{H}_{2} \mathrm{CO}_{3}, \\
& \mathrm{H}_{2} \mathrm{CO}_{3}=\mathrm{H}^{+}+\mathrm{HCO}_{3}{ }^{-}, \\
& \mathrm{HCO}_{3}{ }^{-1}=\mathrm{H}^{+}+\mathrm{CO}_{3}{ }^{2-},
\end{aligned}
$$

and

$$
\begin{aligned}
\left(\mathrm{Ca}_{1-x} \mathrm{Mg}_{x}\right) \mathrm{CO}_{3(\mathrm{~s})}+2 \mathrm{H}^{+}=(1-x) & \mathrm{Ca}^{2+} \\
& +x \mathrm{Mg}^{2+}+2 \mathrm{HCO}_{3}^{-} .
\end{aligned}
$$




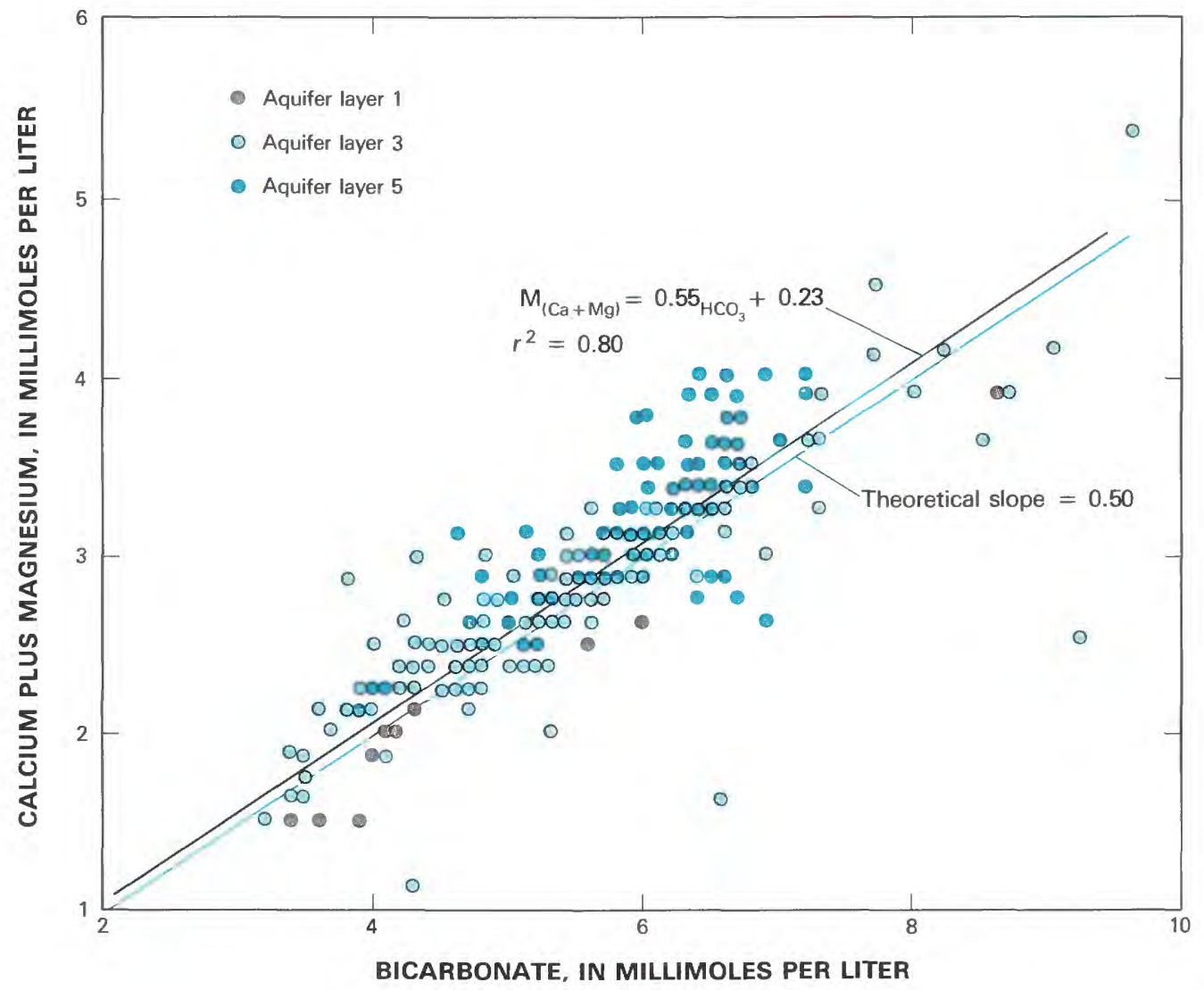

Figure 10.-Correlation of calcium plus magnesium and bicarbonate in ground water from the Ca-Mg$\mathrm{HCO}_{3}$ facies in aquifer layers 1,3 , and 5 in the northern outcrop area of the Cambrian-Ordovician aquifer system.

Combining equations 1 through 4 and neglecting $\mathrm{CO}_{3}{ }^{2-}$ because of the near-neutral $\mathrm{pH}$ conditions in the aquifer,

$$
\begin{aligned}
\left(\mathrm{Ca}_{1-x} \mathrm{Mg}_{x}\right) \mathrm{CO}_{3(\mathrm{~s})} & +\mathrm{H}_{2} \mathrm{O}+\mathrm{CO}_{2(\mathrm{~g})} \\
& =(1-x) \mathrm{Ca}^{2+}+x \mathrm{Mg}^{2+}+2 \mathrm{HCO}_{3}^{-} .
\end{aligned}
$$

Little information exists on the mole fractions of calcium and magnesium in the major carbonate minerals in either the Cambrian-Ordovician aquifer system or the overlying units in aquifer layer 5. A large number of rock analyses of carbonate units from Minnesota obtained from the Cambrian-Ordovician aquifer system are available-for example, Prokopovich and Schwartz (1956), Thiel and Stauffer (1947), and Stauffer (1950)-and show that there is both wide vertical and wide areal variability in the $\mathrm{CaO}$ and $\mathrm{MgO}$ content of the aquifer carbonate rocks and confining units. It is likely that there is a similar variability in calcium and magnesium content of the carbonate rocks elsewhere in the study area.
However, if dissolved calcium, magnesium, and bicarbonate in the ground water result mainly from the dissolution of carbonate minerals according to equation 5, then the molar proportions of $\left(\mathrm{Ca}^{2+}+\mathrm{Mg}^{2+}\right)$ to $\mathrm{HCO}_{3}{ }^{-}$should be linear with a slope of 0.5. Calcium and magnesium are summed because of variability of the mole fractions within the carbonate minerals. The line of regression (fig. 10) of $\left(\mathrm{Ca}^{2+}+\mathrm{Mg}^{2+}\right.$ ) versus $\mathrm{HCO}_{3}{ }^{-}$ for ground-water samples in aquifer layers 1, 3, and 5 in the northern outcrop area of the Cambrian-Ordovician aquifer system in Minnesota, Wisconsin, and northeastern Iowa has a slope of 0.55 . The coefficient of correlation $\left(r^{2}\right)$ is 0.80 , which indicates a good fit between the carbonate-dissolution model and field data.

The state of equilibrium between ground water and carbonate minerals can be tested by use of saturation indices $(S I)$, expressed as

$$
S I_{\text {mineral }}=\log \frac{I A P}{\mathrm{~K}_{\mathrm{sp}}},
$$

where $I A P$ is the ion-activity product calculated from analytical data and $\mathrm{K}_{\mathrm{sp}}$ is the solubility product, an 
equilibrium constant for ions in a saturated solution in contact with excess solid phases.

A saturation index of 0.0 indicates that $I A P$ and $\mathrm{K}_{\mathrm{sp}}$ are equal and that thermodynamic equilibrium of the solution exists with the solid phase in question; a negative or positive index indicates undersaturation and oversaturation, respectively. Saturation indices for calcite and dolomite in selected water samples from aquifer layer 3 in Iowa and northeastern Missouri were determined by use of WATEQF, a U.S. Geological Survey water chemical-equilibrium calculation program (Truesdell and Jones, 1974; Plummer and others, 1976). Saturation indices calculated for calcite and dolomite range generally from about 0.0 to +0.6 and from -0.2 to +1.0 , respectively (fig. 11), for wells in Iowa and northeastern Missouri.

The accuracy of the saturation index for determining equilibrium between solution and carbonate minerals depends largely on the accuracy of field measurements of $\mathrm{pH}$ and alkalinity. The most accurate method of measuring $\mathrm{pH}$ is by using a flow-through cell or bath until $\mathbf{~ p H}$ is constant for at least 15 minutes (Thorstenson and others, 1979). Precision by this method can be within $0.05 \mathrm{pH}$ unit. Unfortunately, during this study the general accuracy of field $\mathrm{pH}$ measurements may have been within only $\pm 0.1 \mathrm{pH}$ unit. Accurate field measurements of alkalinity should be done by potentiometric titration to inflection points rather than to specified end points (Barnes, 1964), which was the method used during this study. The combined errors in $\mathrm{pH}$ measurements and alkalinity determinations could result in errors in saturation indices for carbonate dissolution reactions within a range of 20 percent. Within these error limits, ground water in the CambrianOrdovician aquifer system seems to be nearly saturated or oversaturated with respect to calcite and dolomite (fig. 11).

CALCIUM-SODIUM-SULFATE-BICARBONATE WATER TYPE

$\mathrm{Ca}-\mathrm{Na}-\mathrm{SO}_{4}-\mathrm{HCO}_{3}$ water is common in the drift and the Dakota Formation (table 5) and is present in all aquifer layers that subcrop beneath the Dakota Formation. For instance, samples of water collected at "nests" of vertically spaced observation wells (piezometers) in aquifer layers 1,2 , and 3 in southwestern Minnesota are all of the Ca-Na-SO $-\mathrm{SCO}_{3}$ type (table 6). The relative chemical uniformity of water in aquifer layers 1,2 , and 3 observed in the piezometers in southwestern Minnesota is an important factor in evaluating chemical and hydrologic mechanisms that affect changes in chemistry southeastward along the major direction of groundwater flow in Iowa. Water-quality data are scant for aquifer layers 1,2 , and 4 . If the chemistry of water
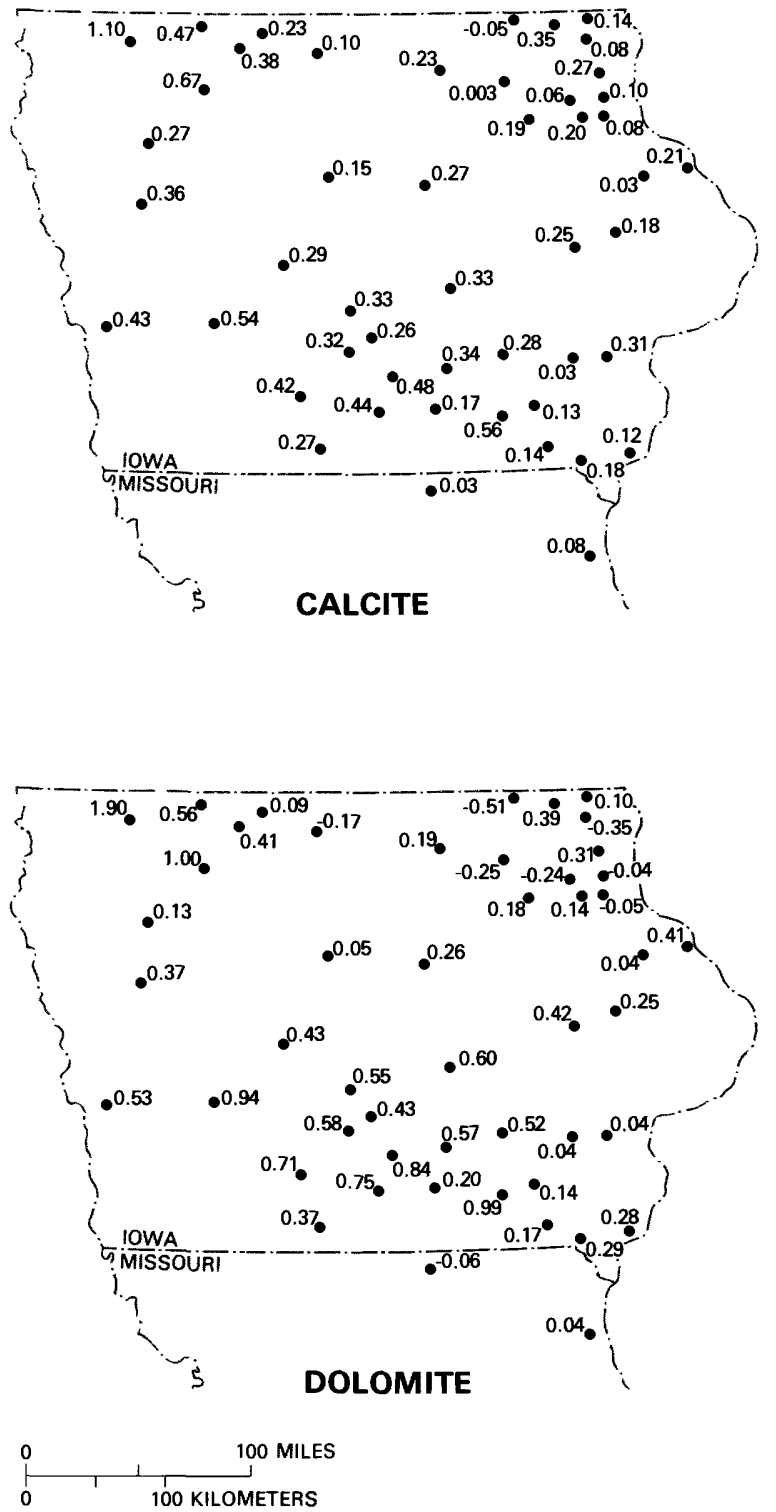

\section{EXPLANATION}

0.08. WELL LOCATION-Number is saturation index, SI (see text for discussion)

Figure 11.-Saturation indices for calcite and dolomite in water from selected wells in aquifer layer 3 in Iowa and northeastern Missouri.

recharging these aquifer layers is similar to the chemistry of the ground water in aquifer layer 3 , one can probably assume that the major geochemical mechanisms that control the water chemistry in all aquifer layers in the recharge areas are generally similar.

The origin of Ca-Na-SO $\mathrm{S}_{4}-\mathrm{HCO}_{3}$ water in the Dakota Formation, the Quaternary drift, and the Cambrian- 
TABLE 5.-Selected chemical analyses of water from the Dakota Formation in northwestern Iowa

[Map number is location in figure 6 ]

\begin{tabular}{|c|c|c|c|c|c|}
\hline & \multicolumn{5}{|c|}{ Well name } \\
\hline & $\begin{array}{l}\text { Suther- } \\
\text { land } \\
\text { no. } 3\end{array}$ & Primghar & $\begin{array}{l}\text { Arthur } \\
\text { no. } 4\end{array}$ & $\begin{array}{l}\text { Schaller } \\
\text { no. } 3\end{array}$ & $\begin{array}{c}\text { Ruthven } \\
\text { no. } 5\end{array}$ \\
\hline Map number & 82 & 81 & 90 & 89 & 83 \\
\hline Date of collection & $2-23-82$ & $2-23-82$ & $2-22-82$ & $2-22-82$ & $2-23-82$ \\
\hline $\begin{array}{l}\text { Temperature } \\
\left({ }^{\circ} \mathbf{C}\right)\end{array}$ & 9.9 & 11.1 & 11.9 & 7.1 & 12.3 \\
\hline $\begin{array}{l}\text { Field pH (stand- } \\
\text { ard units) }\end{array}$ & 7.3 & 7.4 & 7.4 & 7.5 & 7.5 \\
\hline$\underset{(\mathrm{mg} / \mathrm{L})}{\text { Calcium, }} \mathrm{Ca}$ & 320 & - & 260 & 310 & 220 \\
\hline$\underset{(\mathrm{mg} / \mathrm{L})}{\operatorname{Magnesium}}, \mathrm{Mg}$ & 80 & - & 63 & 100 & 58 \\
\hline $\begin{array}{l}\text { Sodium, } \mathrm{Na} \\
(\mathrm{mg} / \mathrm{L})\end{array}$ & 96 & - & 140 & 190 & 100 \\
\hline $\begin{array}{l}\text { Lab alkalinity, as } \\
\mathrm{HCO}_{3}(\mathrm{mg} / \mathrm{L})\end{array}$ & 341 & 412 & 285 & 415 & 404 \\
\hline $\begin{array}{l}\text { Sulfate, } \mathrm{SO}_{4} \\
(\mathrm{mg} / \mathrm{L})\end{array}$ & 930 & 1,000 & 850 & 1,200 & 520 \\
\hline $\begin{array}{c}\text { Chloride, } \mathrm{Cl} \\
\text { (mg/L) }\end{array}$ & 6.7 & 20 & 8.5 & 16 & 5.0 \\
\hline $\begin{array}{l}\text { Dissolved solids, } \\
\text { residue on eva- } \\
\text { poration }(\mathrm{mg} / \mathrm{L})\end{array}$ & 1,790 & - & 1,560 & 2,340 & 1,160 \\
\hline Arsenic, As ( $\mu \mathrm{g} / \mathrm{L})$ & $<50$ & $<50$ & $<50$ & $<50$ & $<50$ \\
\hline Barium, Ba $(\mu \mathrm{g} / \mathrm{L})$ & 9 & 9 & 10 & 8 & 13 \\
\hline$\underset{(\mu \mathrm{g} / \mathrm{L})}{\text { Cadmium, }} \mathrm{Cd}$ & $<2$ & $<2$ & $<2$ & $<2$ & $<2$ \\
\hline$\underset{(\mu \mathrm{g} / \mathrm{L})}{\text { Chromium, }}, \mathrm{Cr}$ & $<5$ & $<5$ & $<5$ & $<5$ & $<5$ \\
\hline $\begin{array}{l}\text { Silica, } \mathrm{SiO}_{2} \\
(\mathrm{mg} / \mathrm{L})\end{array}$ & 11 & 10 & 5 & 12 & 11 \\
\hline Sulfide, $\mathrm{S}(\mu \mathrm{g} / \mathrm{L})$ & $<3$ & $<3$ & $<3$ & $<3$ & $<3$ \\
\hline $\begin{array}{l}\text { Selenium, Se } \\
(\mu \mathrm{g} / \mathrm{L})\end{array}$ & $<5$ & $<5$ & $<5$ & $<5$ & $<5$ \\
\hline Copper, Cu $(\mu \mathrm{g} / \mathrm{L})$ & 6 & 2 & 4 & 3 & 4 \\
\hline Iron, Fe $(\mu \mathrm{g} / \mathrm{L})$ & 2,900 & 1,400 & 2,900 & 71 & 4,200 \\
\hline$\underset{(\mu \mathrm{g} / \mathrm{L})}{\text { Manganese, Mn }}$ & 640 & - & 460 & 2,600 & 270 \\
\hline Nickel, Ni ( $\mu \mathrm{g} / \mathrm{L})$ & $<10$ & - & $<10$ & $<10$ & $<10$ \\
\hline Lead, $\mathrm{Pb}(\mu \mathrm{g} / \mathrm{L})$ & $<50$ & - & $<50$ & $<50$ & $<50$ \\
\hline
\end{tabular}

Ordovician aquifer system in northwestern Iowa and southwestern Minnesota is related to both the oxidation of pyrite and the dissolution of carbonate minerals. Oxidation of pyrite produces sulfuric acid that dissociates to sulfate and hydrogen ions as follows:

$$
\mathrm{FeS}_{2(\mathrm{~s})}+7 / 2 \mathrm{O}_{2(\mathrm{~g})}+\mathrm{H}_{2} \mathrm{O}=\mathrm{Fe}^{2+}+2 \mathrm{SO}_{4}{ }^{2-}+2 \mathrm{H}^{+} .
$$

Depending on the $\mathrm{Eh}$ (redox potential) and $\mathrm{pH}$ of the water, the resultant ferrous iron may then be oxidized to ferric iron,

$$
\mathrm{Fe}^{2+}+1 / 4 \mathrm{O}_{2}+\mathrm{H}^{+}=\mathrm{Fe}^{3+}+1 / 2 \mathrm{H}_{2} \mathrm{O},
$$

which hydrolyzes to form insoluble iron oxides or hydroxide, for example,

$$
\mathrm{Fe}^{3+}+3 \mathrm{H}_{2} \mathrm{O}=\mathrm{Fe}(\mathrm{OH})_{3(\mathrm{~s})}+3 \mathrm{H}^{+} .
$$

TABLE 6.-Water-quality data for water samples obtained from piezometers at Schroeder and Kingstrom sites, Goodhue County, Minn., January 1980

\begin{tabular}{|c|c|c|c|c|c|c|}
\hline & \multicolumn{6}{|c|}{ Well name } \\
\hline & $\begin{array}{c}\text { Schroe- } \\
\text { der } \\
\text { no. } 5\end{array}$ & $\begin{array}{c}\text { Schroe- } \\
\text { der } \\
\text { no. } 2\end{array}$ & $\begin{array}{c}\text { Schroe- } \\
\text { der } \\
\text { no. } 4\end{array}$ & $\begin{array}{l}\text { King. } \\
\text { strom } \\
\text { no. } 1\end{array}$ & $\begin{array}{l}\text { King- } \\
\text { strom } \\
\text { no. } 3\end{array}$ & $\begin{array}{l}\text { King- } \\
\text { strom } \\
\text { no. } 4\end{array}$ \\
\hline Aquifer layer & 1 & 2 & 3 & 1 & 2 & 3 \\
\hline $\begin{array}{l}\text { Field pH (stand- } \\
\text { ard units) }\end{array}$ & 7.1 & 7.3 & 7.2 & 7.2 & 7.3 & 7.1 \\
\hline Calcium, Ca & 148 & 136 & 116 & 140 & 140 & 136 \\
\hline Magnesium, Mg & 41 & 51 & 56 & 63 & 51 & 39 \\
\hline Sodium, $\mathrm{Na}$ & 52 & 62 & 111 & 149 & 74 & 51 \\
\hline Potassium, K & 10 & 19 & 24 & 20 & 26 & 9.7 \\
\hline Silica, $\mathrm{SiO}_{2}$ & 6.6 & 6.3 & 6.7 & 6.4 & 5.7 & 6.6 \\
\hline$\underset{(\mu \mathrm{g} / \mathrm{L})}{\operatorname{Manganese}, \mathrm{Mn}}$ & 69 & 89 & 48 & 240 & 97 & 59 \\
\hline Iron, Fe $(\mu \mathrm{g} / \mathrm{L})$ & 1,900 & 4,500 & 2,600 & 4,600 & 3,500 & 50 \\
\hline $\begin{array}{l}\text { Alkalinity, } \\
\text { as } \mathrm{CACO}_{3}\end{array}$ & 306 & 320 & 317 & 328 & 315 & 317 \\
\hline Sulfate, $\mathrm{SO}_{4}$ & 300 & 370 & 317 & 490 & 400 & 290 \\
\hline Chloride, $\mathrm{Cl}$ & 5.5 & 9.3 & 33 & 49 & 13 & 8.6 \\
\hline $\begin{array}{l}\text { Dissolved solids, } \\
\text { sum of consti- } \\
\text { tuents }\end{array}$ & 860 & 960 & 1,000 & 1,300 & 1,000 & 800 \\
\hline
\end{tabular}

IResult in milligrams per liter, except as indicated Analyses by Minnesota Department of He'althl

Acidity produced in the oxidation process may be neutralized by carbonate minerals (eq. 5) that are found as part of the matrix in the Dakota Formation and the underlying aquifer units.

Sulfate in the Dakota Formation and other aquifers in northwestern Iowa and southwestern Minnesota has also been attributed to possible dissolution of either gypsum $\left(\mathrm{CaSO}_{4} \cdot 2 \mathrm{H}_{2} \mathrm{O}\right)$ or anhydrite $\left(\mathrm{CaSO}_{4}\right)$ (Winter, 1974; Munter and others, 1983). No petrographic evidence of primary evaporite minerals has been noted in the literature, however. Dissolution of gypsum proceeds rapidy compared with dissolution of carbonates and other common minerals in the aquifer matrix. The hydraulic conductivity of the Dakota Formation is generally low owing to bedded shale and siltstone. Therefore, the residence time of ground water in the Dakota probably is long. This is supported by the carbon- 14 dates for water in the Dakota ranging from 22,000 to more than 35,000 years B.P. (before present) (D.L. Iles, South Dakota Geological Survey, written commun., 1982). Because of this long residence time, ground water in the Dakota Formation should be in equilibrium with gypsum, if gypsum is present, as should the ground water in aquifer layer 3 , where the ground water is recharged from the Dakota. However, negative saturation indices for gypsum in ground water in aquifer layer 3 in northwestern Iowa (fig. 12) show the water to be undersaturated with respect to gypsum, and this indi- 

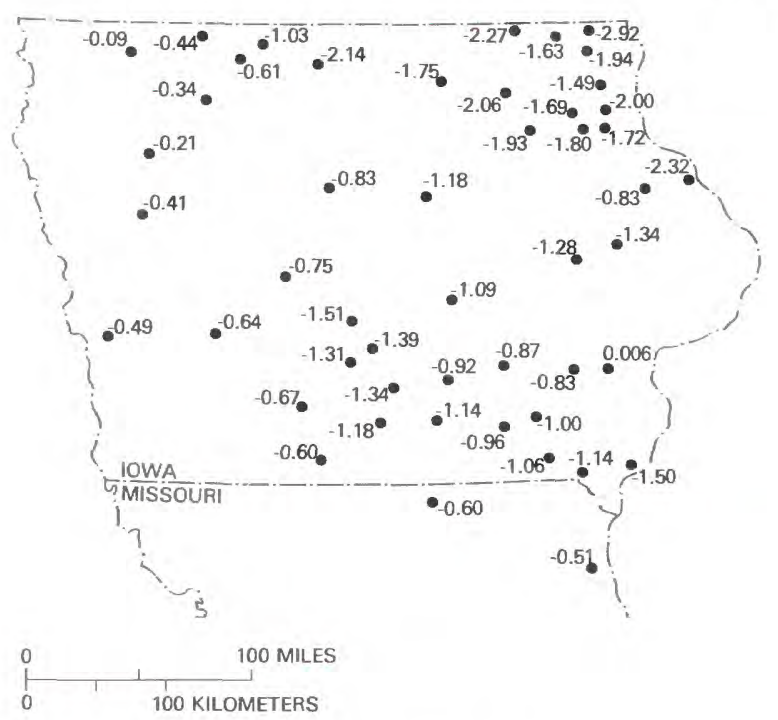

\section{EXPLANATION}

-0.75 WELL LOCATION-Number is saturation index, $S I$ (see text for discussion)

Figure 12.-Saturation indices for gypsum in water from selected wells in aquifer layer 3 in Iowa and northeastern Missouri.

rectly indicates that there is not enough gypsum in the Dakota Formation to be the source of sulfate, as suggested by other investigators.

Data on the isotopic composition of sulfur in sulfate is another way to test independently whether the sulfur is from the oxidation of pyrite $\left(\mathrm{FeS}_{2}\right)$ or the dissolution of gypsum or anhydrite. Negative $\delta^{34} S$ values typically indicate that the source of sulfur is weathered sulfide from shales, whereas positive values generally indicate an evaporitic mineral source (Holser and Kaplan, 1966; Hitchon and Krouse, 1972; Hoefs, 1980).

The $\delta^{34} \mathrm{~S}$ in sulfate from the Cambrian-Ordovician aquifer system and the Dakota Formation in northwestern Iowa (fig. 13) ranges from -10.8 to -1.0 permil (parts per thousand, written $\%$ oo), considerably lighter than $\delta^{34} \mathrm{~S}$ associated with marine evaporites in the Cretaceous Period (Claypool and others, 1980). $\delta^{34} \mathrm{~S}$ of pyrite and other disseminated sulfide minerals in shales tends to be less than $+10 \%$ oo, the lower limit for evaporitic sulfate (Holser and Kaplan, 1966). These values are similar to isotopic sulfur ratios in streams that drain basins underlain by marine Cretaceous rock, roughly similar to the Dakota Formation, in the MacKenzie River Basin of Canada (Hitchon and Krouse, 1972). The values of $\delta^{34} \mathrm{~S}$ indicate that the original source of sulfur was probably pyrite in the Dakota Formation.
The isotopic composition of the sulfur in sulfate reflects the isotopic composition of the sulfur in the original pyrite and depends on many factors. Sulfur isotopes approach equilibrium at earth temperatures and pressures very slowly (Pearson and Rightmire, 1980). Most differences in sulfur isotope content in aqueous sulfur compounds are caused by kinetic fractionation accompanying inorganic or bacterial reduction or by oxidation of sulfur compounds (Kaplan and Rittenburg, 1964; Goldhaber and Kaplan, 1974). Hydrogen sulfide degassing is a common problem in many wells in the Dakota Formation; this indicates that reducing conditions do exist locally in the formation (U.S. Geolgical Survey, unpub. data; Burkart, 1984). In southwestern Minnesota, methane is also common in both drift and the underlying Cambrian-Ordovician aquifer system (Coleman, 1978, 1979).

$\delta^{34} \mathrm{~S}$ in sulfate in aquifer layer 3 is enriched downgradient from the northwestern recharge area in central Iowa but is still less than +10 \%oo (fig. 13). The $\delta^{34} \mathrm{~S}$ enrichment may be related to the preferential bacterial reduction and consequent loss of sulfur-32 in $\mathrm{H}_{2} \mathrm{~S}$ or metal sulfide precipitates. Although sulfide in solution is present in the aquifer system in central Iowa (fig. 14), data are insufficient to document the presence of such possible bacteriological mediation of the reduction process. The low concentrations of sulfide may reflect precipitation of pyrite or other metal sulfides. Calculations from the WATEQF program show that sulfide-bearing solutions are supersaturated with respect to pyrite.

Some input of sulfur to the aquifer system could have been from the oxidation of pyrite in the Maquoketa Shale along the outcrop area in northeastern Iowa. However, the scant data on the isotopic content of sulfur in sulfate in central Iowa (fig. 13) show $\delta^{34} \mathrm{~S}$ greater than $+5 \%$ oo, which is considerably heavier than that of the sulfur in sulfate derived from either the oxidation of pyrite in northwestern Iowa or from the Maquoketa Shale in northeastern Iowa.

Elsewhere in the aquifer system, $\delta^{34} \mathrm{~S}$ in sulfate may indicate a sulfur source from evaporite minerals. East of the Maquoketa confining unit in northern Illinois, $\delta^{34} \mathrm{~S}$ in sulfate in oxidized water is about $+20 \%$ /oo and is too enriched to be derived solely from the oxidation of sulfide minerals (Perry and others, 1982). Gilkeson and others (1981) proposed that some of the sulfate may have been placed in the aquifer system during Pleistocene glaciations and may be related to Michigan basin evaporites. Hydraulic gradients in Illinois, at least during the Wisconsin ice advances, could have been from east to west, reversed from current hydraulic gradients, because of the pressure head from the weight of the ice sheets that periodically covered the Lake Michigan 


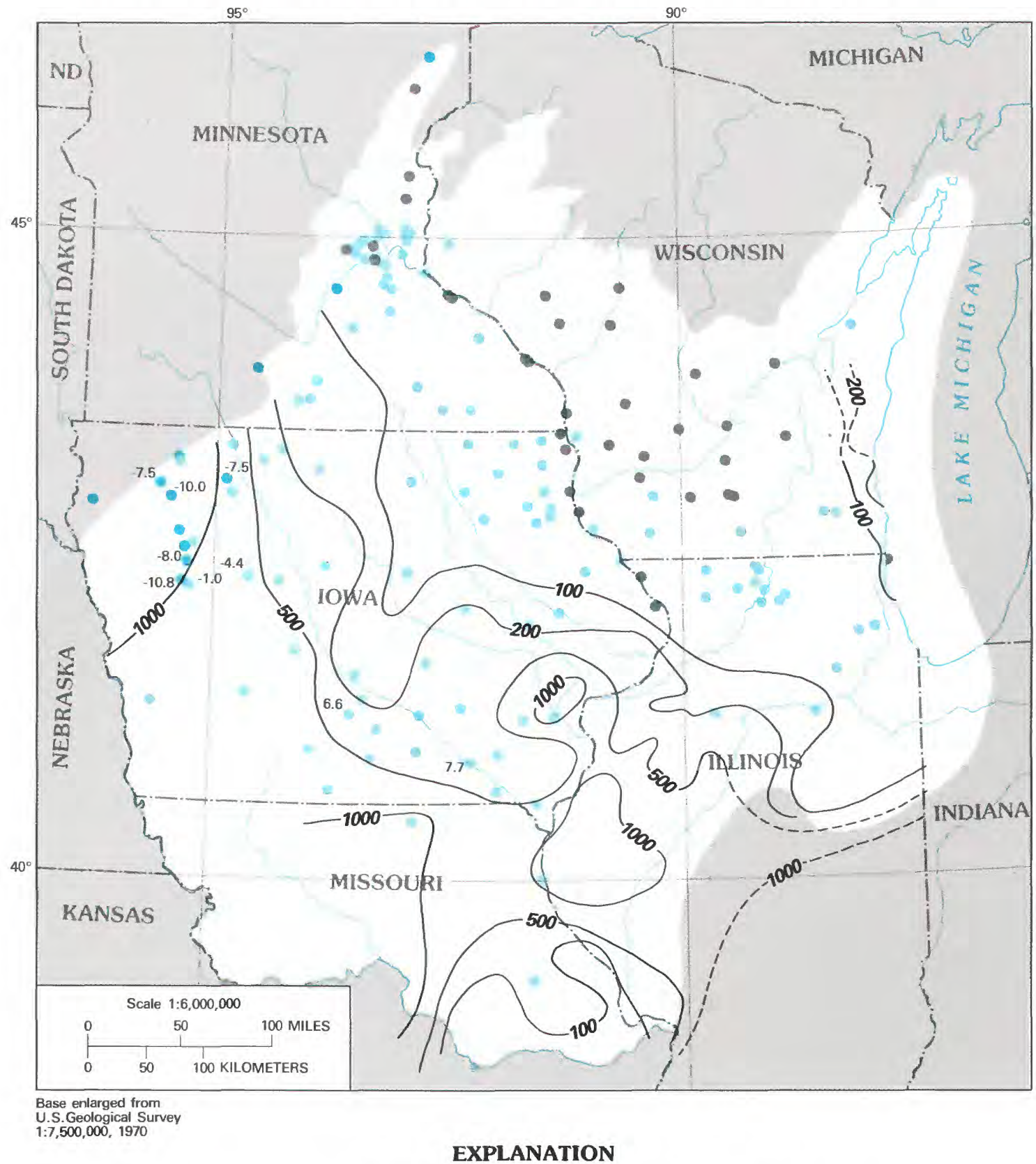

$-500-$ LINE OF EQUAL CONCENTRATION OF SULFATE-Dashed where
approximate. Interval, in milligrams per liter, is variable
WELL SAMPLED FOR CHEMICAL ANALYSIS DURING THIS STUDY
Number is isotopic composition of sulfur in sulfate, $\delta^{34} \mathrm{~S}$, permil
$-\quad$ Open to aquifer layer 1
$-4.4 \quad \begin{aligned} & \text { Open to aquifer layer } 3 \\ & -7.5 \quad \text { Open to aquifer layer } 5\end{aligned}$

FIGURE 13.-Sulfate distribution in aquifer layers 1 and 3 and sulfur isotopic composition in sulfate in water from selected wells in aquifer layer 3 and aquifer layer 5 (Dakota Formation). 


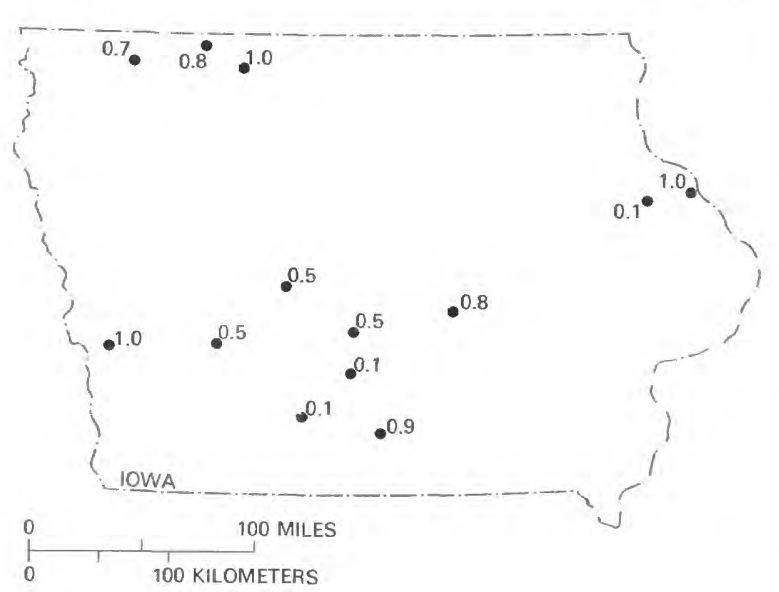

EXPLANATION

1.0 WELL LOCATION-Number is sulfide concentration in milligrams per liter

Figure 14.-Sulfide distribution in water from selected wells in aquifer layer 3 in Iowa.

basin (Gilkeson and others, 1981; Filley and Parizek, 1983; Siegel and Mandle, 1983). The influence of Pleistocene glaciations on the water chemistry of the Cambrian-Ordovician aquifer system was profound and is discussed in a later section, "Isotopic Composition of Water and Pleistocene Recharge Model."

\section{SODIUM-MIXED ANION WATER TYPE}

The evolution of $\mathrm{Ca}-\mathrm{Na}-\mathrm{SO}_{4}-\mathrm{HCO}_{3}$ water to $\mathrm{Na}-\mathrm{Ca}$ $\mathrm{SO}_{4}-\mathrm{HCO}_{3}$ and $\mathrm{Na}-\mathrm{Cl}$ water is well illustrated in figure 15 , a plot of analyses in terms of equivalent weights on the trilinear diagram of Piper (1944). Data fiom wells along geochemical sections $A-A^{\prime}$ and $B-B^{\prime}$ indicate a trend toward sodium predominance on the cation plot, and toward chloride predominance on the anion plot. The increase in sodium and the decrease in calcium and magnesium along the flow path could be the result of several processes.

Sodium could be contributed by dissolution of sodium-bearing silicate or evaporite minerals in the aquifer system. However, no petrographic evidence exists to indicate the presence of halite $(\mathrm{NaCl})$ in the aquifer system, and the dissolution rate of sodic plagioclase $\left(\mathrm{NaAlSi}_{3} \mathrm{O}_{8}\right)$ is much too slow to account for the concentrations of sodium found in central Iowa.

The inverse relationship between concentrations of sodium and alkaline-earth metals could also be explained by ion exchange, which has been identified in many aquifer systems elsewhere (for example, Foster,
1950; Krothe and Parizek, 1979; Thorstenson and others, 1979; Krothe and Bergeron, 1981; Chapelle and Knobel, 1983). Exchange would follow the generalized reaction

$$
\mathrm{M}^{2+}+\mathrm{Na}_{2}-\mathrm{Clay}=2 \mathrm{Na}^{+}+\mathrm{M}-\mathrm{Clay},
$$

where $\mathrm{M}^{2+}$ is $\mathrm{Ca}^{2+}+\mathrm{Mg}^{2+}$ or other alkaline-earth metals.

Micaceous clays such as illite and glauconite are more common in the Cambrian-Ordovician aquifer system than are mixed-layered clays such as montmorillonite and smectite, which are usually associated with cation exchange. Major clay minerals in the Ordovician Decorah Formation and Glenwood Formation, which are part of the Maquoketa confining unit that separates aquifer layer 3 from aquifer layer 4, are kaolinite and illite (Parham and Austin, 1967, 1969). However, distinctive beds of potassium montmorillonite have been identified in the Decorah Formation and other Ordovician formations throughout the study area (Mossler and Hayes, 1966). Although the presence of montmorillonite in Ordovician and Cambrian rocks suggests that significant cation-exchange capacity may be present in the aquifers, such exchange probably cannot completely account for the linear plot of the cations (fig. 15). If cation exchange were the dominant mechanism, the plot would trend more parallel to the calciumsodium axis rather than toward the sodium apex (Piper, 1944), unless exchange of calcium and magnesium for sodium occurred at rates that would maintain similar Ca:Mg molar ratios along the flow path. Covariance of the molality of sodium to molality of $(\mathrm{Ca}+\mathrm{Mg})$ has a low coefficient of correlation $\left(r^{2}\right)$ of 0.3 and a slope of +2.1 . If ion exchange were a major process, $r^{2}$ would be closer to unity and the slope would be close to -2 (Chapelle, 1983). Given the areal variability and probable scarcity of clays having high cation-exchange capacity for calcium and magnesium in the aquifer system, it is unlikely that much ion exchange occurs except in recharge areas underlain by clayey till and the Dakota Formation.

Mixtures of two waters will also plot on straight lines if all solutes remain in solution and do not increase or decrease as a result of chemical reactions. The linearity of the cation plot (fig. 15) may indicate simple mixing of $\mathrm{Na}$-mixed anion water with $\mathrm{Ca}-\mathrm{Na}$-mixed anion water, but the curvilinear fit of the anion data indicates sources and sinks along the flow path with respect to bicarbonate and sulfate.

Although cation trends on the trilinear diagrams could indicate mixing of two types of water, sodium and chloride concentrations along the major southeastward direction of ground-water flow across Iowa probably 


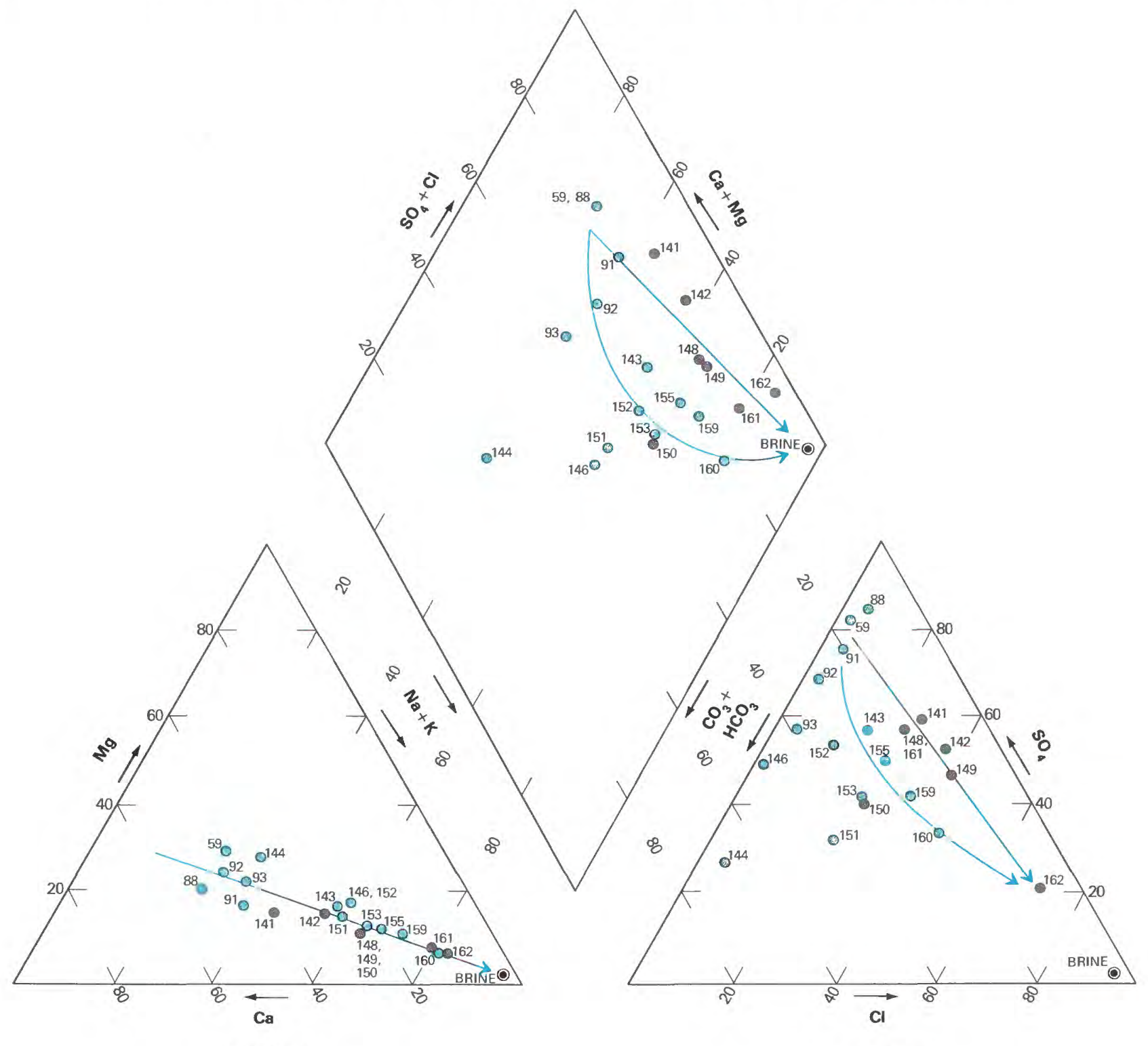

CATIONS

ANIONS

PERCENT OF TOTAL MILLIEQUivaleNTS PER LITER

\section{EXPLANATION}

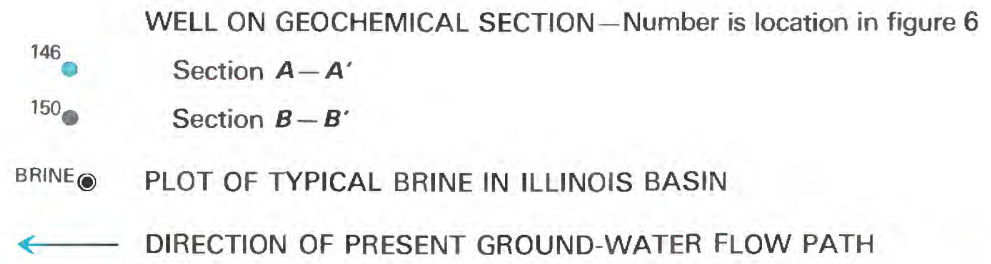

Figure 15.-Trilinear diagram of water chemistry along geochemical sections $A-A^{\prime}$ and $B-B^{\prime}$. 
reflect a gradual mineralization of the waters as they approach the $\mathrm{Na}-\mathrm{Cl}$ brines of the Illinois basin. The origin of the brines is related to reverse chemical osmosis and membrane filtration (Graf and others, 1965; Clayton and others, 1966; Hanshaw and Coplen, 1973; Graf, 1982). The combined effects of these processes that concentrate sodium and chloride probably extend upgradient in the Cambrian-Ordovician aquifer system outside the Illinois basin proper. For example, chloride concentrations increase to more than $100 \mathrm{mg} / \mathrm{L}$ in southern Iowa, halfway down the regional flow paths from northwestern and western Iowa to southeastern Iowa (fig. 16). The overall trend toward more chloride-rich waters occurs even in central Iowa within the plume of low-dissolved-solids water, where concentrations of chloride are several times greater than to the northeast (figs. 7, 16). Figures 17 and 18 show concentrations of major constituents along geochemical sections $A-A^{\prime}$ and $B-B^{\prime}$. Concentrations of chloride and sodium begin to increase from south-central Iowa down the major flow paths to the southeast toward the Illinois basin.

The trilinear plot of anions (fig. 15) shows that, although chloride is less than 10 percent, sulfate decreases from about 80 percent at the recharge area in western Iowa to about 55 percent near the Mississippi River. Bicarbonate plus carbonate increases from less than 20 percent to more than 40 percent. The apparent inverse relationship between equivalents of these constituents suggests that sulfate is possibly being reduced to sulfide along the hydraulic gradient, probably with an associated loss of oxygen, in the presence of a reducing agent such as organic material.

If the reducing agent is organic material, the following reactions are possible:

$$
\begin{aligned}
15 \mathrm{CH}_{2} \mathrm{O}+2 \mathrm{Fe}_{2} \mathrm{O}_{3}+ & 8 \mathrm{SO}_{4}{ }^{2-}+\mathrm{H}_{2} \mathrm{CO}_{3} \\
= & 4 \mathrm{FeS}_{2}+16 \mathrm{HCO}_{3}{ }^{-}+8 \mathrm{H}_{2} \mathrm{O}
\end{aligned}
$$

or

$$
\mathrm{SO}_{4}{ }^{2-}+2 \mathrm{CH}_{2} \mathrm{O}+2 \mathrm{H}^{+}=\mathrm{H}_{2} \mathrm{~S}+2 \mathrm{CO}_{2}+2 \mathrm{H}_{2} \mathrm{O} \text {. }
$$

Hematite $\left(\mathrm{Fe}_{2} \mathrm{O}_{3}\right)$ and ferric oxyhydroxide $[\mathrm{FeO}(\mathrm{OH})]$ are common in the Cambrian-Ordovician aquifer system. Organic material is less common, but bacteriogenic decomposition of organic material occurs within the overlying Dakota Formation. Thus, recharge from the Dakota Formation and possible reduction of organic material in shales associated with aquifer layer 3 could produce bacteriogenic methane in water. Methane concentrations of as much as $15 \mathrm{ppm}$ in aquifer layer 3 and $7 \mathrm{ppm}$ in aquifer layers 2 and 1 were identified in southwestern Minnesota (Coleman, 1978; Minnesota
Department of Natural Resources, written commun., 1981).

The equivalent weight of sulfate lost should approximately equal that of bicarbonate gained if the reactions are a reasonable explanation for the observed chemical changes (eqs. 11, 12). A plot of equivalents of sulfate against bicarbonate for sections $A-A^{\prime}$ and $B-B^{\prime}$ shows the contrary (fig. 19); as sulfate decreases, bicarbonate remains the same, at about $5 \mathrm{meq} / \mathrm{L}$. Furthermore, saturation indices indicate that the ground water is oversaturated or is nearly in equilibrium with calcite and dolomite (fig. 11). Bicarbonate concentrations remain constant even in the vicinity of the dilute plume in central Iowa. If the dilute plume is caused by dilution of ground water with recharge water of low dissolvedsolids content, the uniform bicarbonate concentrations and saturation indices would suggest that ground water has reequilibrated with carbonate minerals in the aquifer since the dilution episode or episodes. The mechanism, timing, and amount of such recharge can be explained hypothetically by glacial advances during the Pleistocene and are discussed later in the section "Isotopic Composition of Water and Pleistocene Recharge Model."

\section{TRACE AND MINOR CONSTITUENTS}

The areal distribution of many trace constituents in the aquifer system is related approximately to the availability of the constituents in the source rocks. Although specific data on the trace-element content of the aquifer matrix is lacking, compilation of the average distribution of elements in major rock types (Turekian and Wedepohl, 1961; Drever, 1982) indicates that higher concentrations of many transition metals are found in shales rather than in carbonate rocks or sandstones. Concentrations of the alkaline earth strontium and of halogens, such as bromine and fluorine, are more variable with respect to rock type.

The areal distribution of the transitional metals cadmium and arsenic in the aquifer system may be related to the proximity of the argillaceous Dakota Formation. Concentrations of these metals are generally less than 5 $\mu \mathrm{g} / \mathrm{L}$, except where the aquifer subcrops beneath the Dakota Formation in northwestern Iowa and southwestern Minnesota (fig. 20). Scant data suggest that selenium concentrations are less than $5 \mu \mathrm{g} / \mathrm{L}$ except at one location beneath the Dakota Formation. Cadmium concentrations may also increase to more than $5 \mu \mathrm{g} / \mathrm{L}$ in southeastern Iowa and northeastern Missouri on the edge of the Illinois basin. Concentrations of iron and manganese increase where the aquifer is overlain by the Dakota Formation and by drift derived from the Dakota (fig. 21). For example, concentrations of iron 


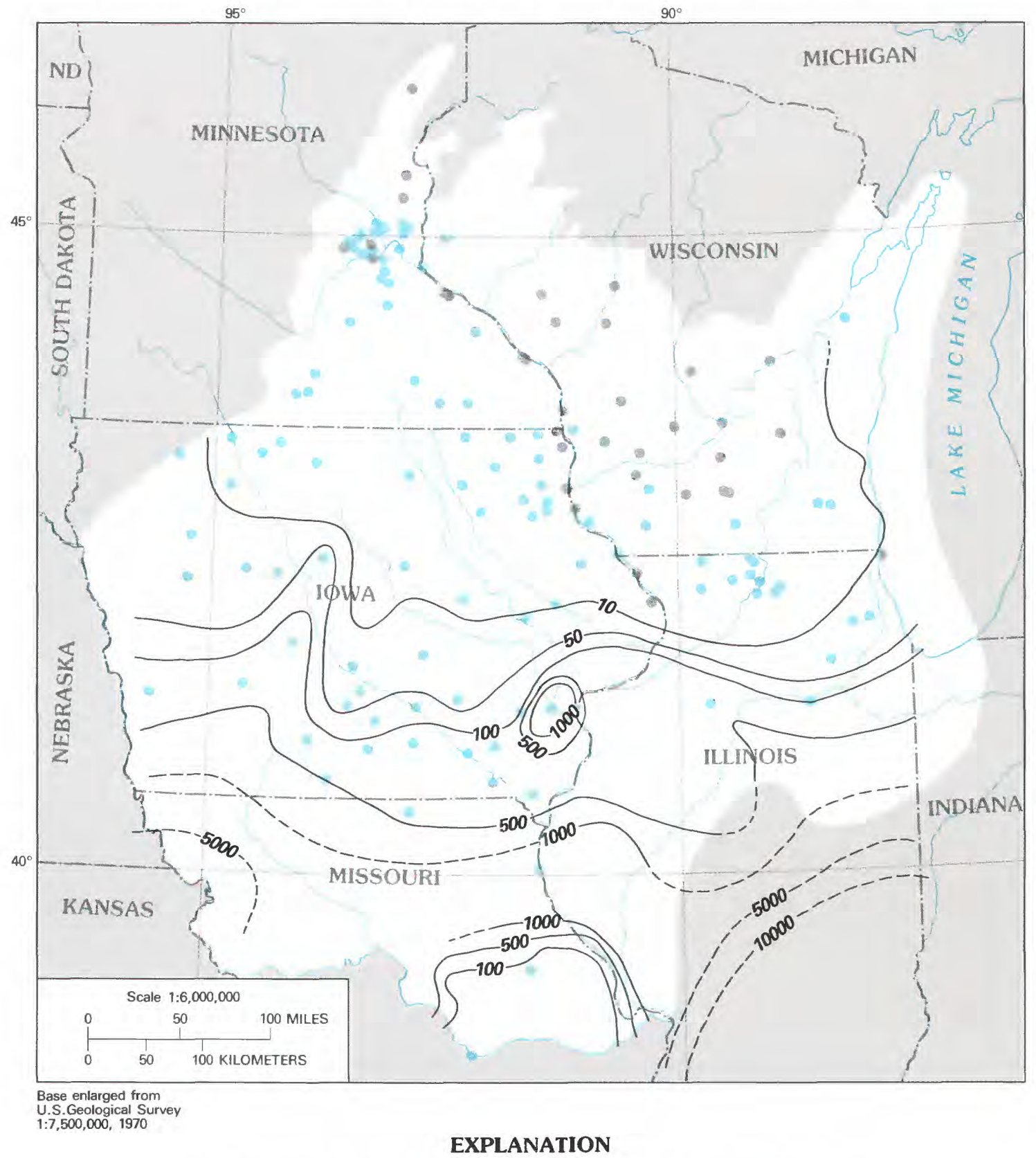

-50-- LINE OF EQUAL CHLORIDE CONCENTRATION-Dashed where approximate. Interval, in milligrams per liter, is variable

WELL SAMPLED FOR CHEMICAL ANALYSIS DURING THIS STUDY Open to aquifer layer 1

Open to aquifer layer 3

FIGURE 16.-Chloride distribution in aquifer layers 1 and 3. 

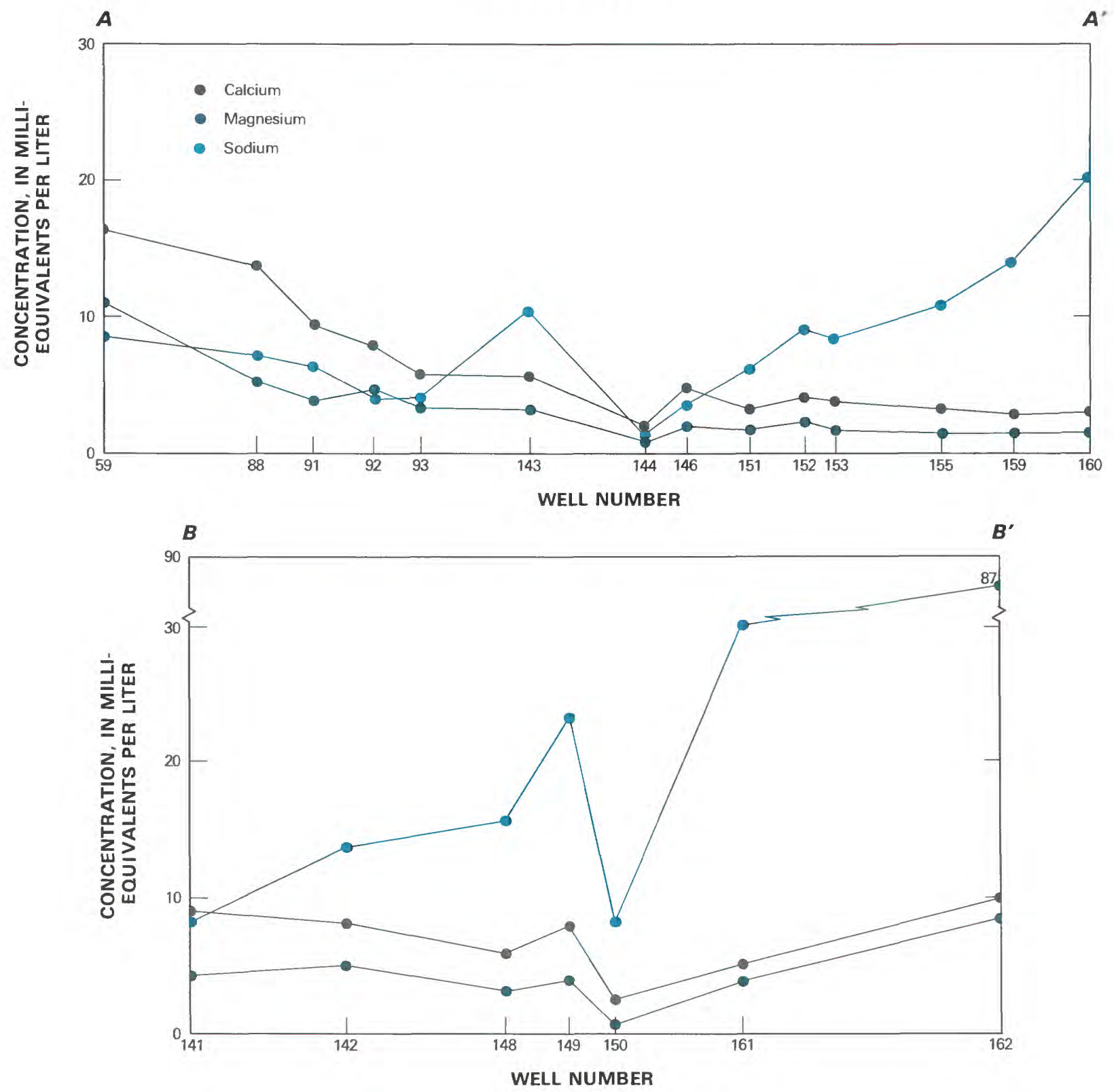

Figure 17.-Concentrations of major cations in water from wells in aquifer layers 1 and 3 along geochemical sections $A-A^{\prime}$ and $B-B^{\prime}$. (Location of wells shown in fig. 6 .)

and manganese exceed $1,000 \mu \mathrm{g} / \mathrm{L}$ and $100 \mu \mathrm{g} / \mathrm{L}$, respectively, in northwestern Iowa. Concentrations of iron, manganese, copper, lead, and cobalt increase in southwestern Iowa near the margin of the Forest City basin (figs. 21, 22). Concentrations of cadmium and copper are more than 5 and $20 \mu \mathrm{g} / \mathrm{L}$, respectively, in southeastern Iowa near the western flank of the Illinois basin (figs. 20, 22).

The controls on the concentrations of these and other trace metals are complicated and are related as much to complexation of metals by organic and inorganic ligands, sorption of metals onto solids, and oxidationreduction potential of the water as to the metal content of the source rock (Garrels and Christ, 1965; Stumm and Morgan, 1981; Eichenberger and Chen, 1982; Hem, 1985). The influence of these processes on the tracemetal content of the water cannot be evaluated at the present time because the detection limits of the analyses for the metals were at reconnaissance levels and because information on the composition of dissolved organic carbon in the water and regional mineralogical and trace-metal composition of the aquifer matrix are 

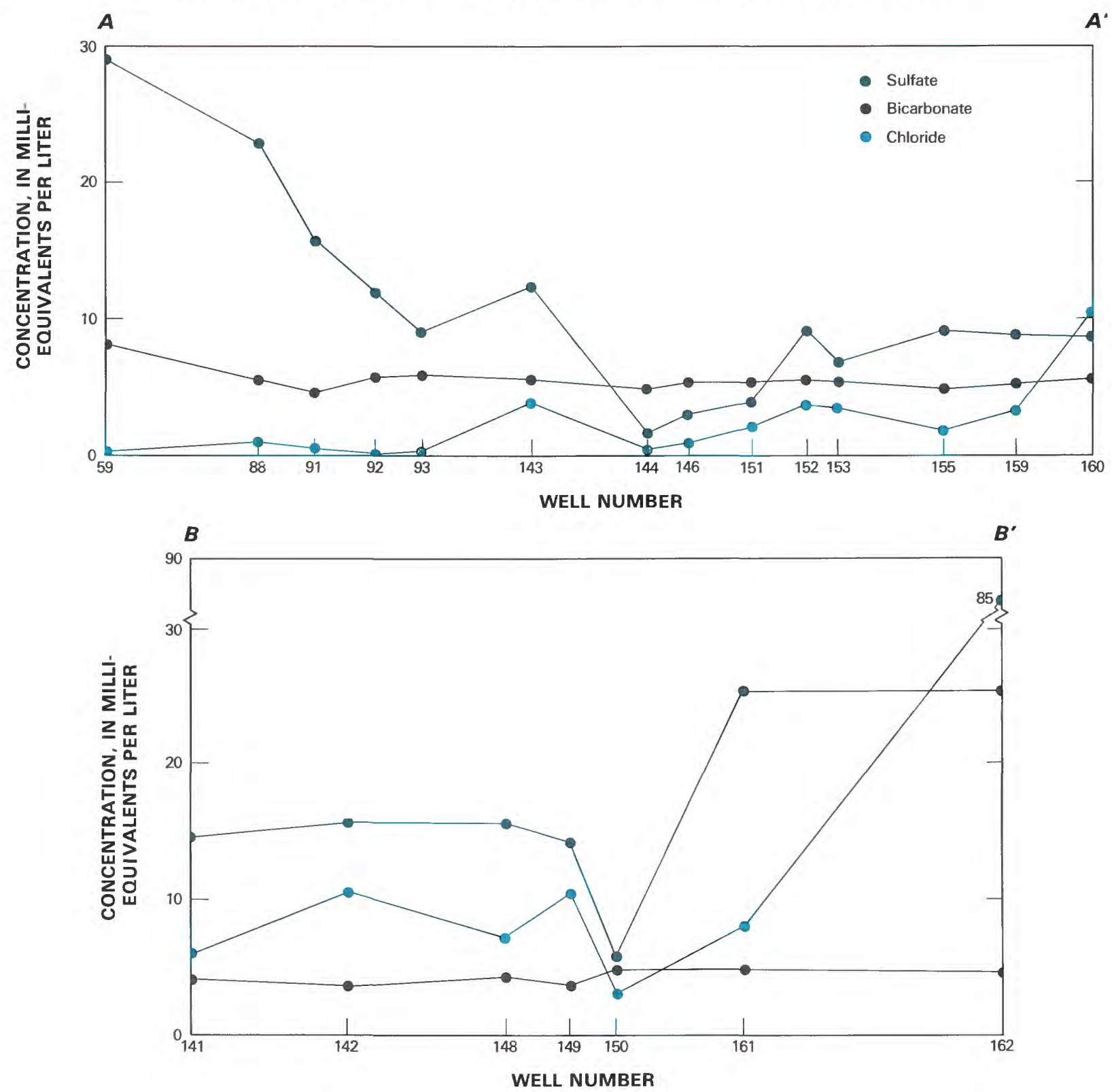

FIGURE 18.-Concentrations of major anions in water from wells in aquifer layers 1 and 3 along geochemical sections $A-A^{\prime}$ and $B-B^{\prime}$. (Location of wells shown in fig. 6.)

lacking. Some trace metals, such as iron, can be reduced by bacteria at the $\mathrm{pH}$ values prevalent in the aquifer. Reducing conditions, identified by measurable dissolved sulfide, are present throughout the aquifer where it is confined by the Maquoketa Shale (fig. 14) and locally in the Dakota Formation (Burkart, 1984), and they probably are a major control on trace-metal concentrations in western Iowa.

The relationship between some trace-metal concentrations in ground water and proximity to the Forest City basin may be indicated by concentrations of beryl- lium and molybdenum of more than 1 and $10 \mu \mathrm{g} / \mathrm{L}$, respectively, in southwestern Iowa (fig. 23). Concentrations of these and other metals may increase near the Illinois basin. However, no trace-metal data for water from the Cambrian-Ordovician aquifer system are available for that area. Several wells in northeastern and north-central Iowa inexplicably have molybdenum concentrations of more than $10 \mu \mathrm{g} / \mathrm{L}$.

Some trace constituents that have relatively similar average concentrations in different sedimentary rock types show increases in concentration in ground water 


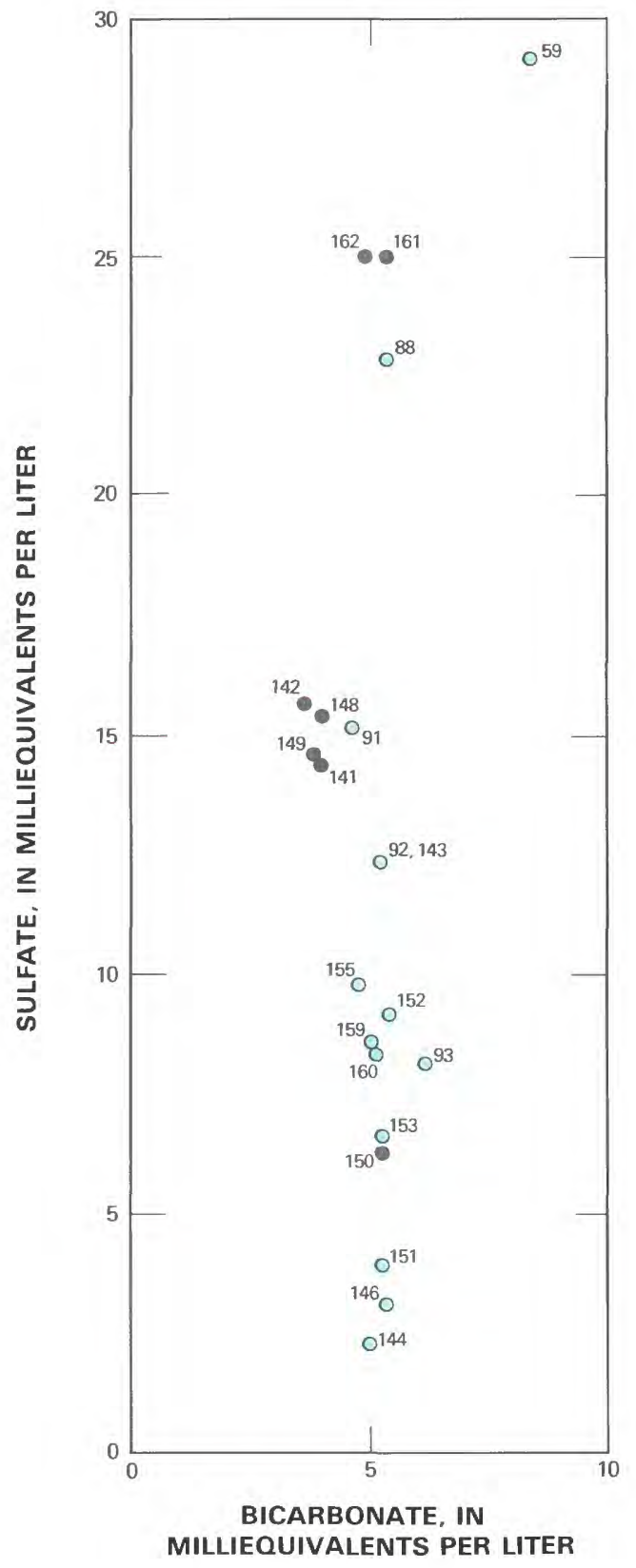

EXPLANATION

WELL ON GEOCHEMICAL SECTION-Number is well location in figure 6

${ }^{59} \circ$ Section $\boldsymbol{A}-\boldsymbol{A}^{\prime}$

141 Section $\boldsymbol{B}-\boldsymbol{B}^{\prime}$

Figure 19.-Sulfate-bicarbonate relationship along geochemical sections $A-A^{\prime}$ and $B-B^{\prime}$. southwestward across Iowa and eastward across Wisconsin. For example, fluoride concentrations increase from less than 1 to more than $2 \mathrm{mg} / \mathrm{L}$, lithium from less than 10 to more than $400 \mu \mathrm{g} / \mathrm{L}$, boron from less than 200 to more than $2,000 \mu \mathrm{g} / \mathrm{L}$, and strontium from less than 1,000 to more than $6,000 \mu \mathrm{g} / \mathrm{L}$ across Iowa (figs. 24-27). Strontium concentrations exceed $1,000 \mu \mathrm{g} / \mathrm{L}$ in eastern Wisconsin where dissolved solids generally exceed 500 mg/L (Nichols and McNall, 1957; Kammerer, 1981). Boron concentrations exceed $5,000 \mu \mathrm{g} / \mathrm{L}$ near the western edge of the Illinois basin (fig. 26).

There is no identifiable plume of dilute concentration of trace constituents in Iowa (as there is for dissolved solids), with the exception of bromide (fig. 28) and possibly lithium (fig. 25). Bromide concentrations in the aquifer are generally less than $0.5 \mathrm{mg} / \mathrm{L}$ except near the western edge of the Illinois basin, where concentrations approach $10 \mathrm{mg} / \mathrm{L}$. In central and southern Iowa, a broad zone of bromide concentration of less than 0.5 $\mathrm{mg} / \mathrm{L}$ is surrounded by areas of bromide concentrations of greater than $1.0 \mathrm{mg} / \mathrm{L}$ (fig. 28). This distribution roughly matches the dilution shown by the dissolvedsolids distribution (fig. 7). Bromide is a conservative, relatively nonreactive constituent and therefore is a good indicator of hydrological processes that involve mixing of different water types. The lack of similar dilution plumes in the distribution of strontium, fluoride, and boron suggests that chemical processes other than mixing have controlled the distribution of these trace constituents, thus masking the reacharge plume(s).

Concentrations of barium in the ground water are related both to source and to geochemical processes. Gilkeson and others (1981) showed that barium concentrations or more than $1 \mathrm{mg} / \mathrm{L}$ in northeastern Illinois are due to a zone of reducing conditions in the confined Cambrian-Ordovician aquifer system. Sulfate ion is reduced to sulfide, thereby allowing concentrations of barium to increase until the solubility limit of barite $\left(\mathrm{BaSO}_{4}\right)$ is reached. Concentrations exceeding $100 \mu \mathrm{g} / \mathrm{L}$ in the northwestern part of the study area are probably due to barium contained in shales of the Dakota Formation (fig. 29). Concentrations also exceed $100 \mu \mathrm{g} / \mathrm{L}$ in the northeastern corner of Iowa near the Mississippi River. The cause of the higher barium concentrations in Iowa is unknown. Higher barium concentrations also are present in the aquifer in southeastern Wisconsin along the strike of the Maquoketa Shale, apparently an extension of the conditions in northeastern Illinois. Additional work is needed to determine whether the solubility of barite controls the high barium concentrations in these waters. 


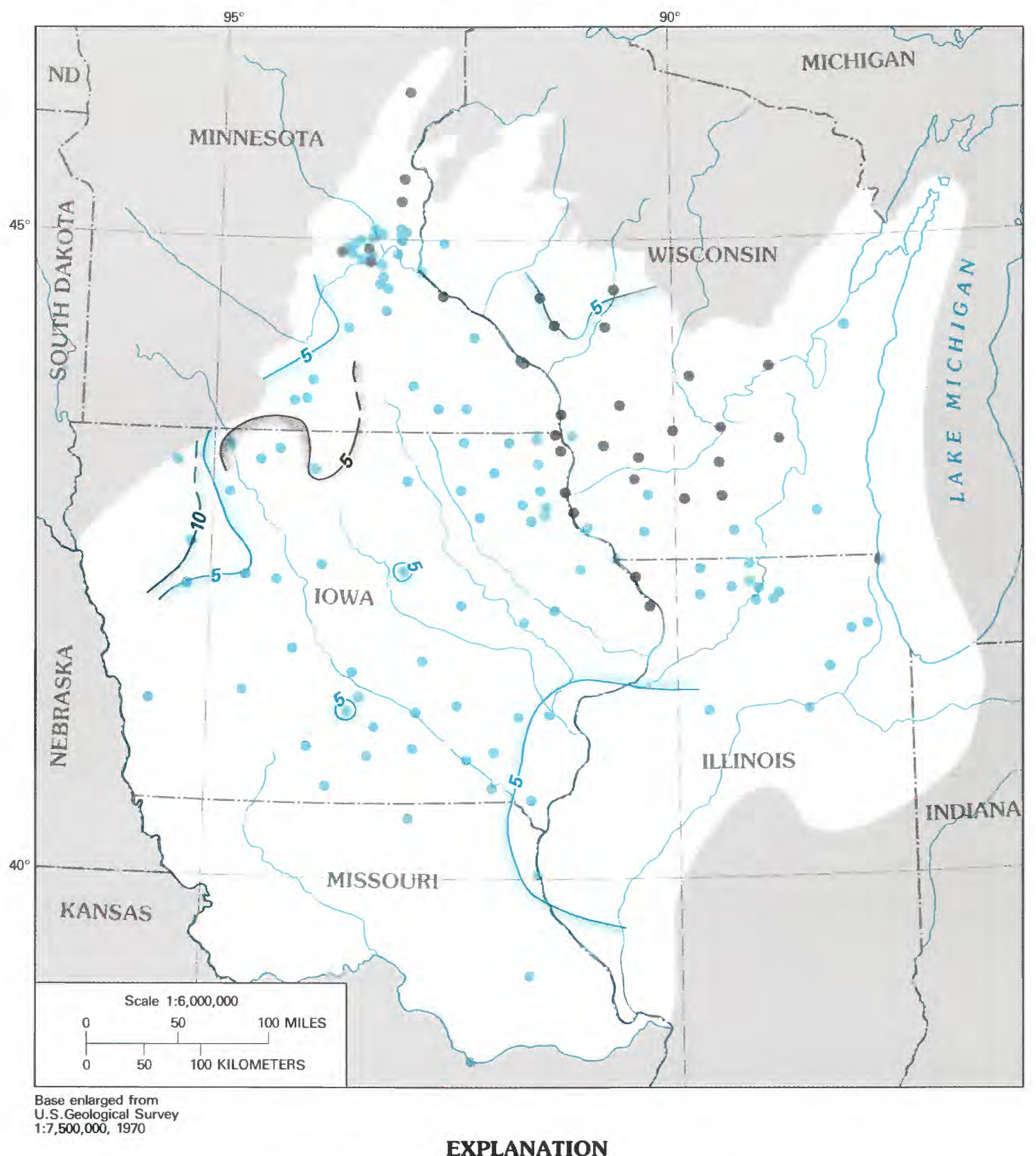

LINES OF EQUAL CONCENTRATION - Stippled in direction of lower concentration. Dashed where approximate. Interval, in micrograms per liter, is variable

$$
\begin{array}{ll}
-5- & \text { Cadmium } \\
--5- & \text { Arsenic } \\
-10- & \text { Selenium }
\end{array}
$$

\section{WELL SAMPLED FOR CHEMICAL ANALYSIS DURING THIS STUDY}

- Open to aquifer layer 1

- Open to aquifer layer 3

Figure 20.-Distribution of dissolved cadmium, arsenic, and selenium in aquifer layers 1 and 3. 


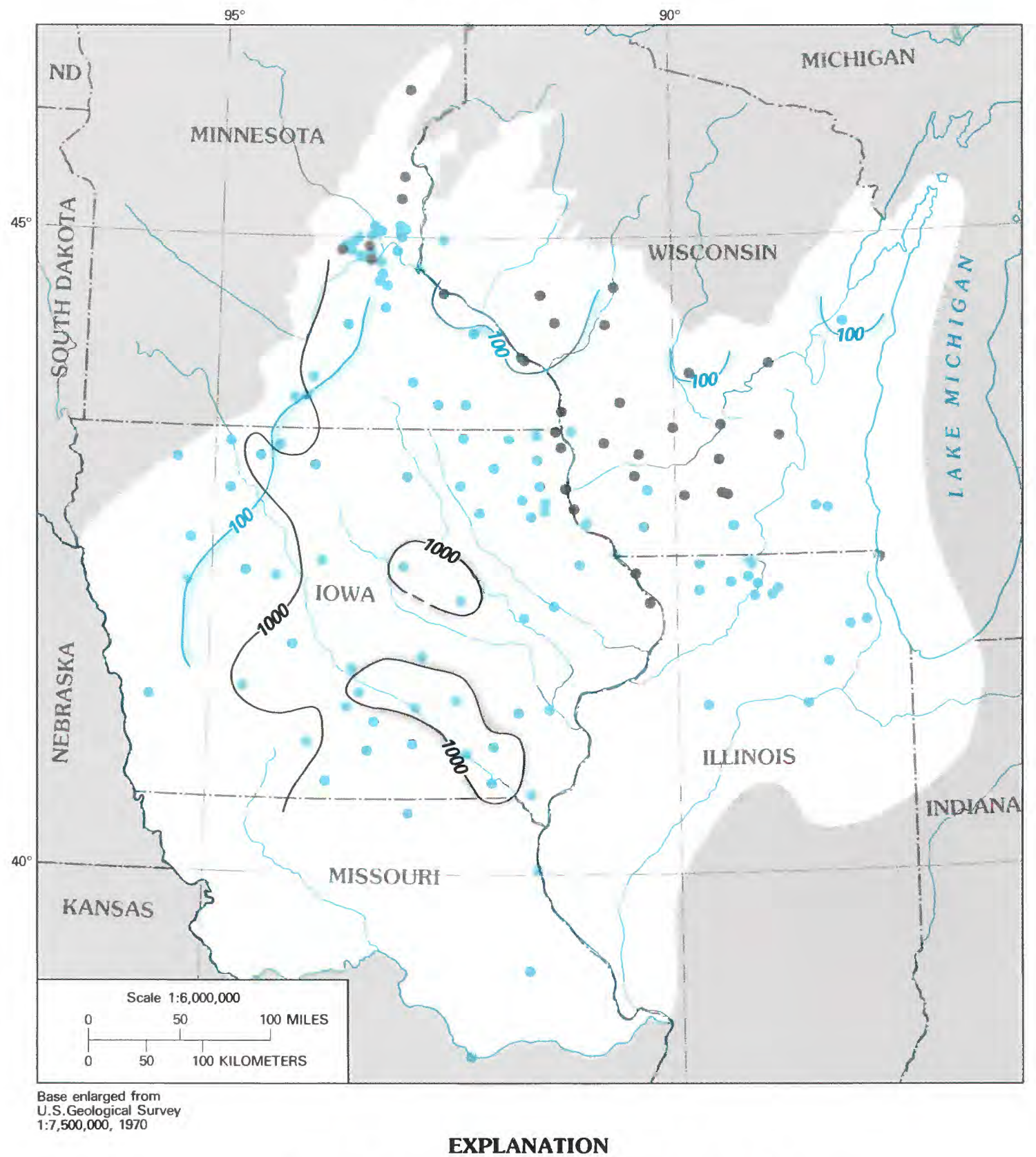

LINES OF EQUAL CONCENTRATION - Stippled in direction of lower concentration. Dashed where approximate. Interval, in micrograms per liter, is variable

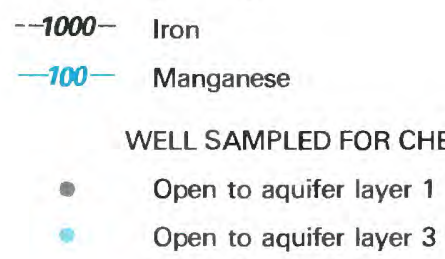

FIGURE 21.-Distribution of dissolved iron and manganese in aquifer layers 1 and 3. 


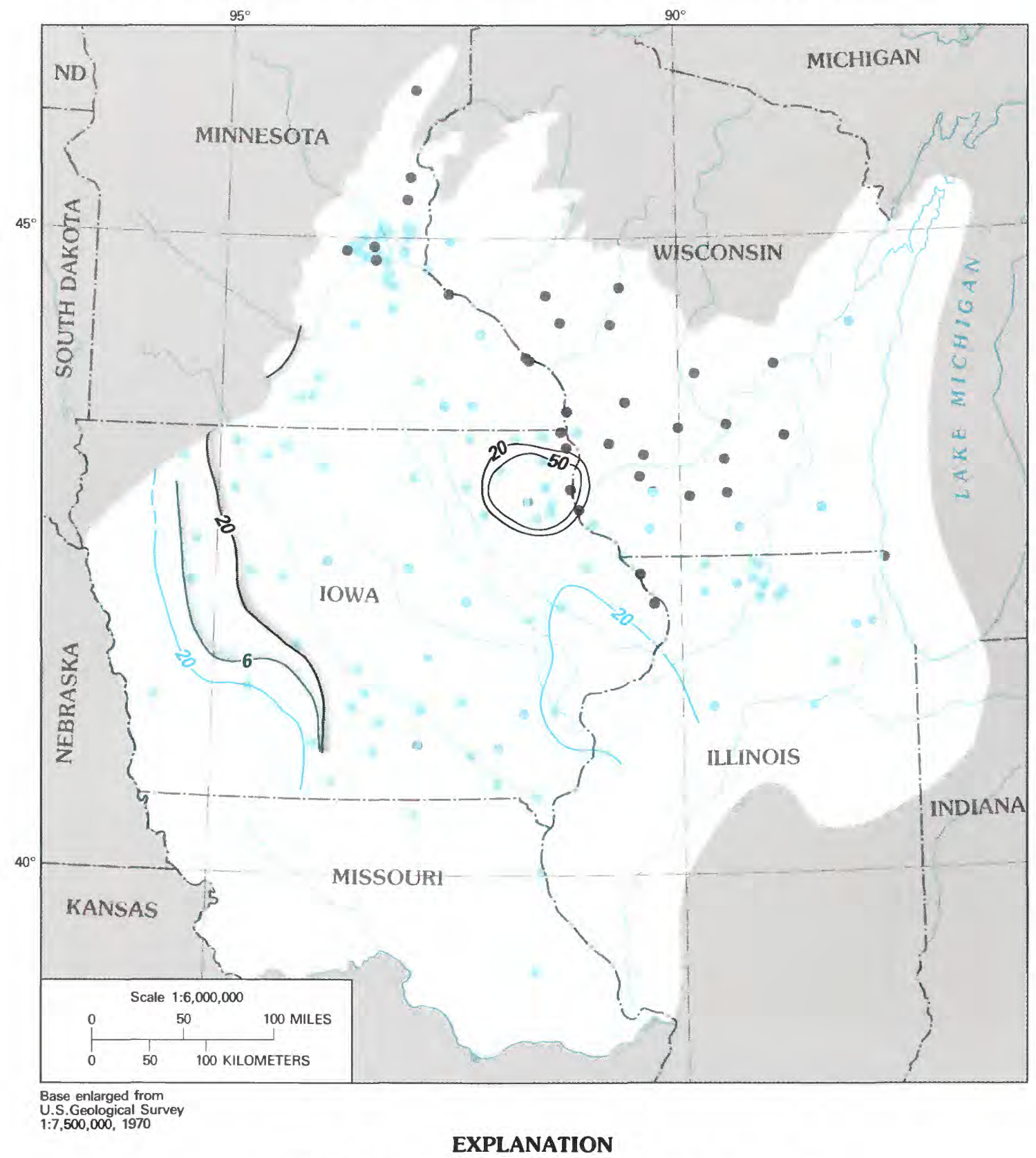

LINES OF EQUAL CONCENTRATION - Stippled in direction of lower concentration. Dashed where approximate. Interval, in micrograms per liter, is variable

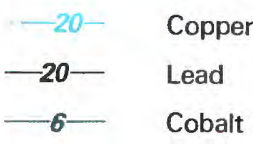

WELL SAMPLED FOR CHEMICAL ANALYSIS DURING THIS STUDY

- Open to aquifer layer 1

Open to aquifer layer 3

Figure 22.-Distribution of dissolved copper, lead, and cobalt in aquifer layers 1 and 3. 

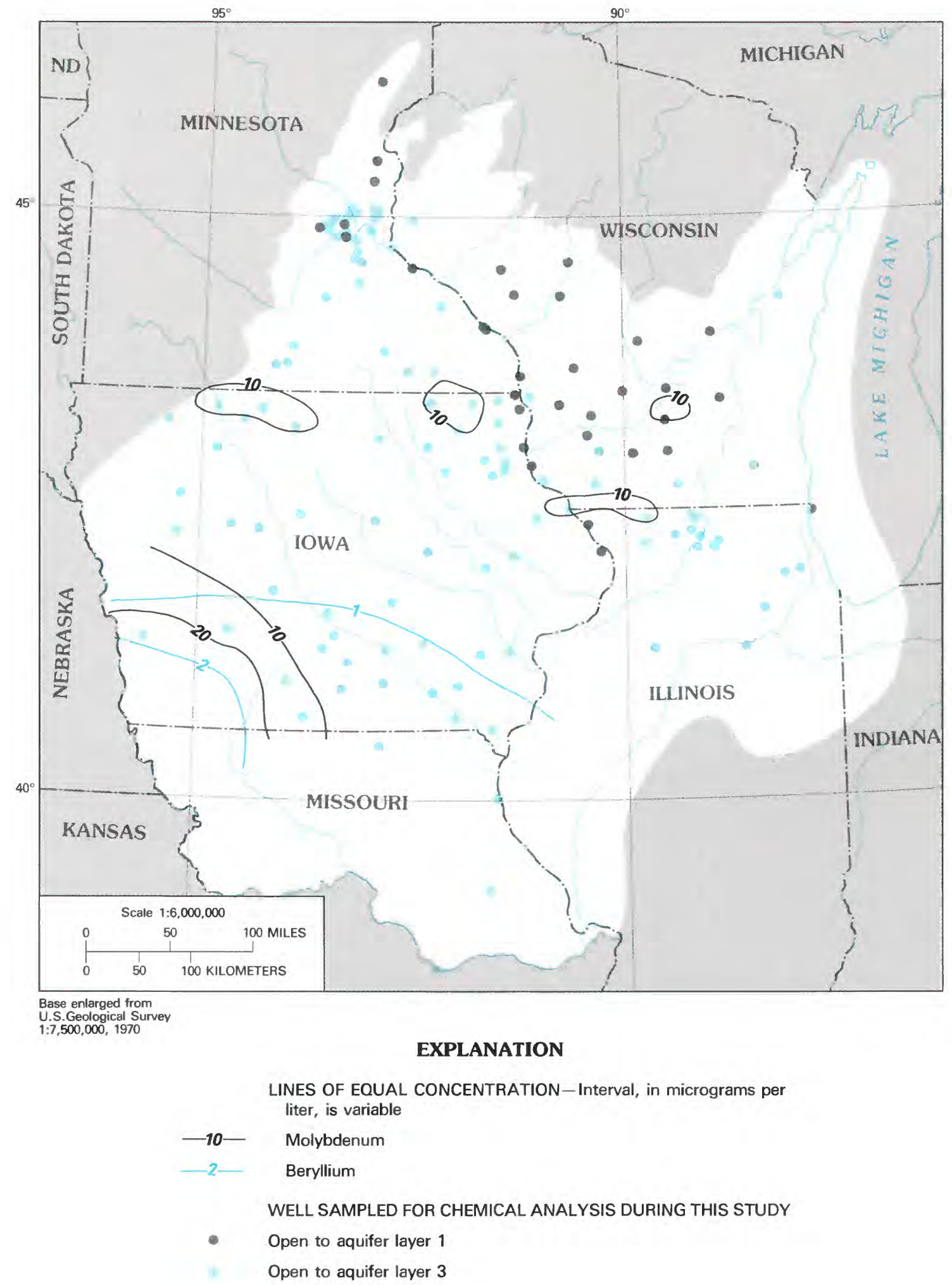

Figure 23,-Distribution of dissolved molybdenum and beryllium in aquifer layers 1 and 3. 


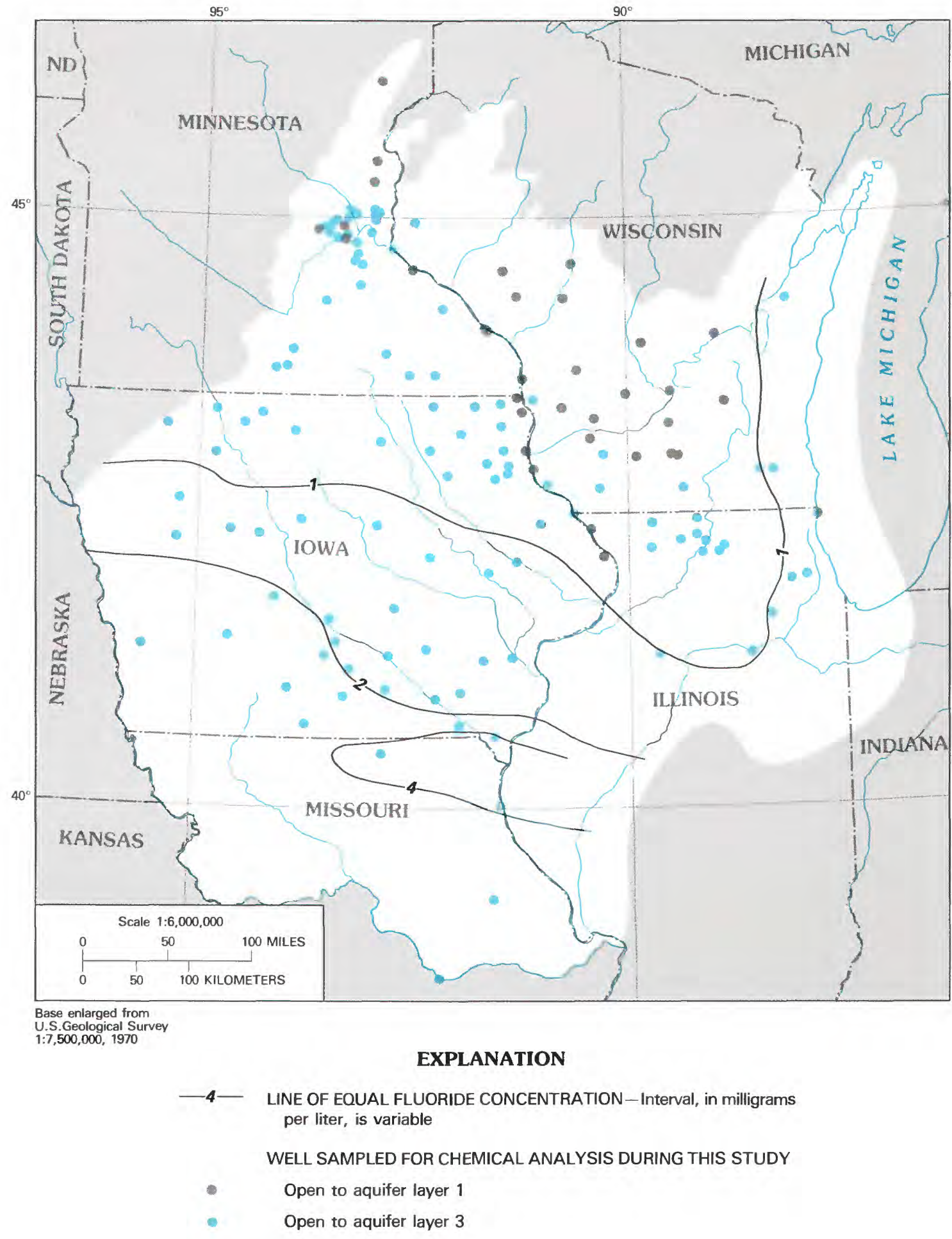

Figure 24.-Distribution of dissolved fluoride in aquifer layers 1 and 3. 


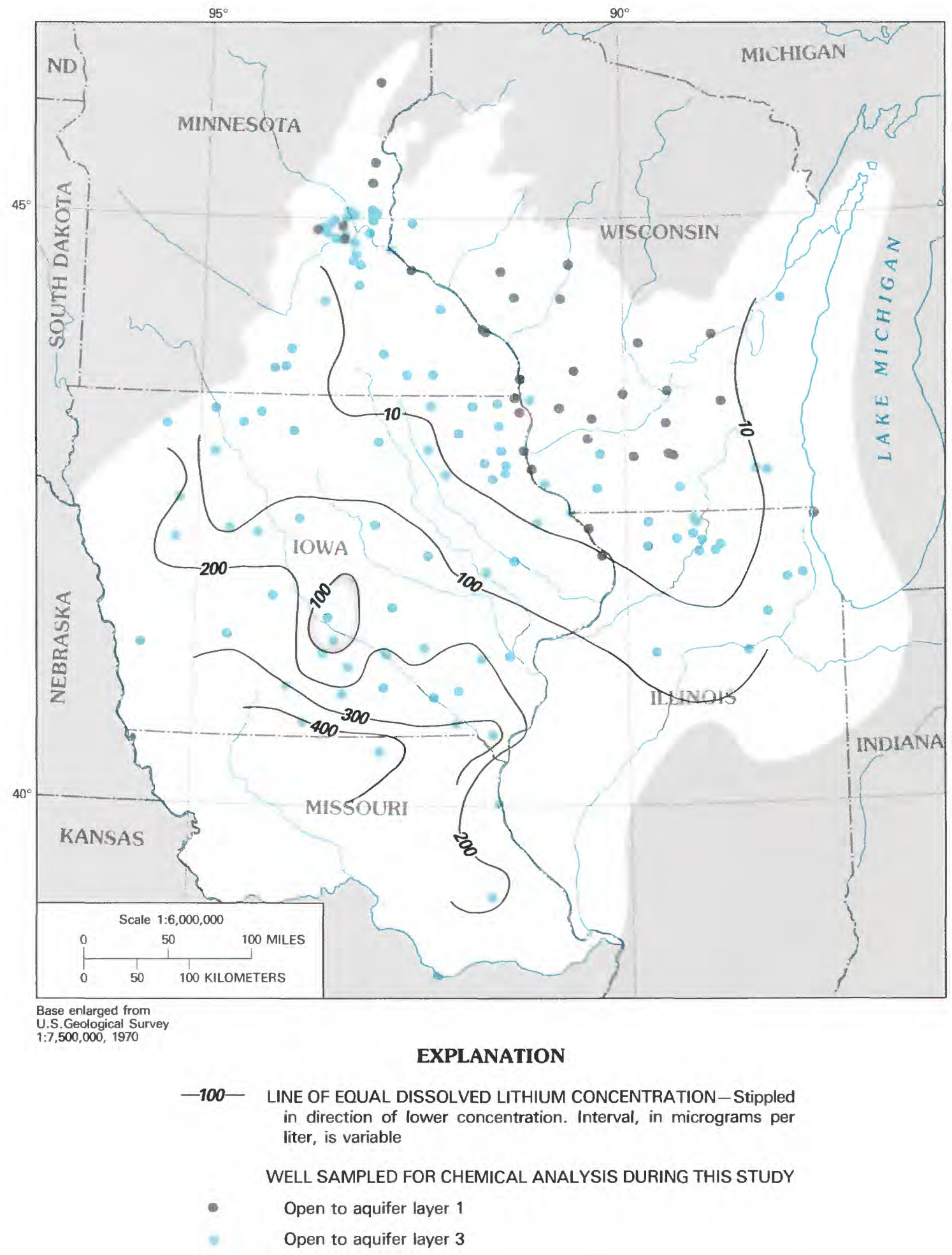

FIgURE 25.-Distribution of dissolved lithium in aquifer layers 1 and 3. 


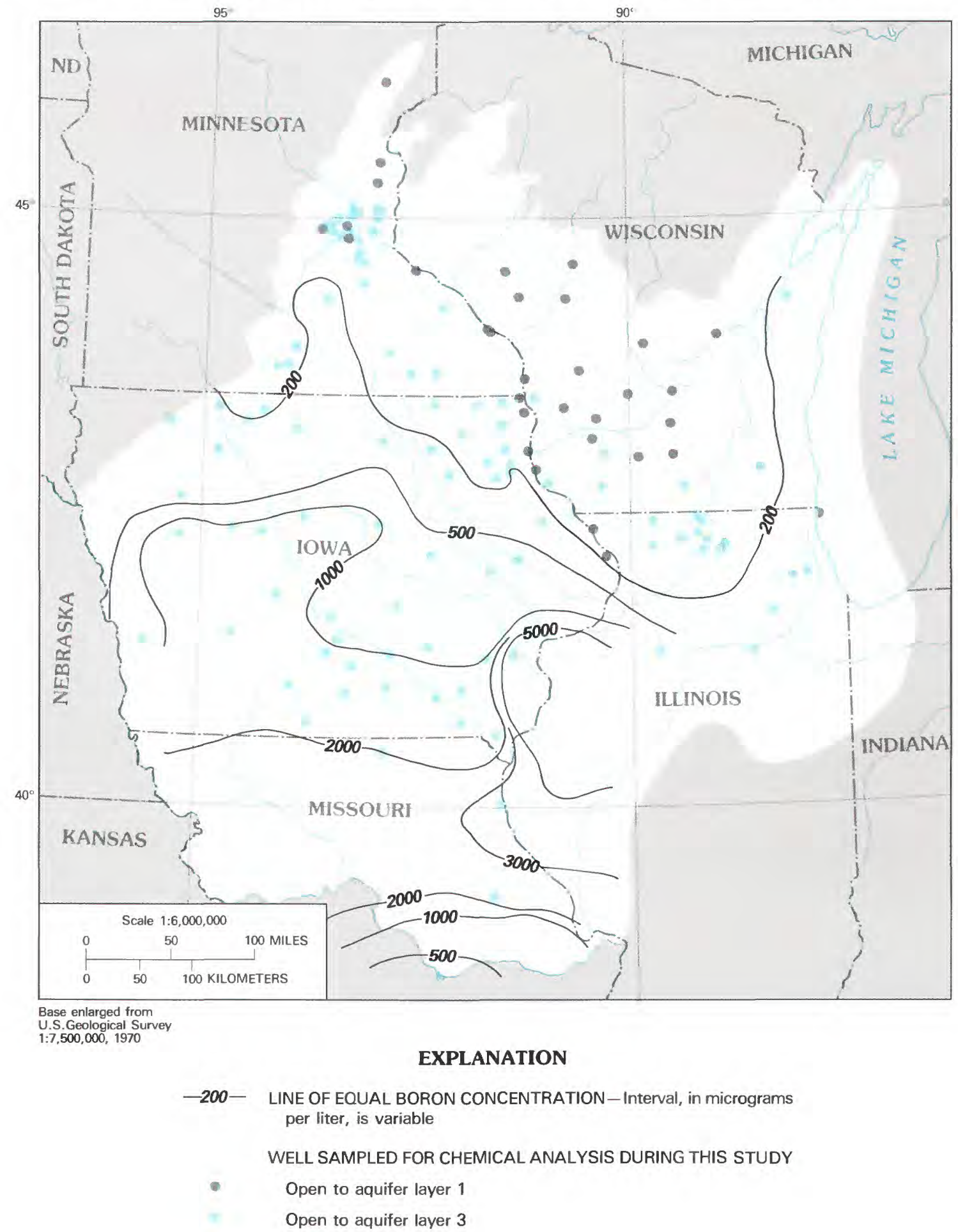

Figure 26.-Distribution of dissolved boron in aquifer layers 1 and 3. 


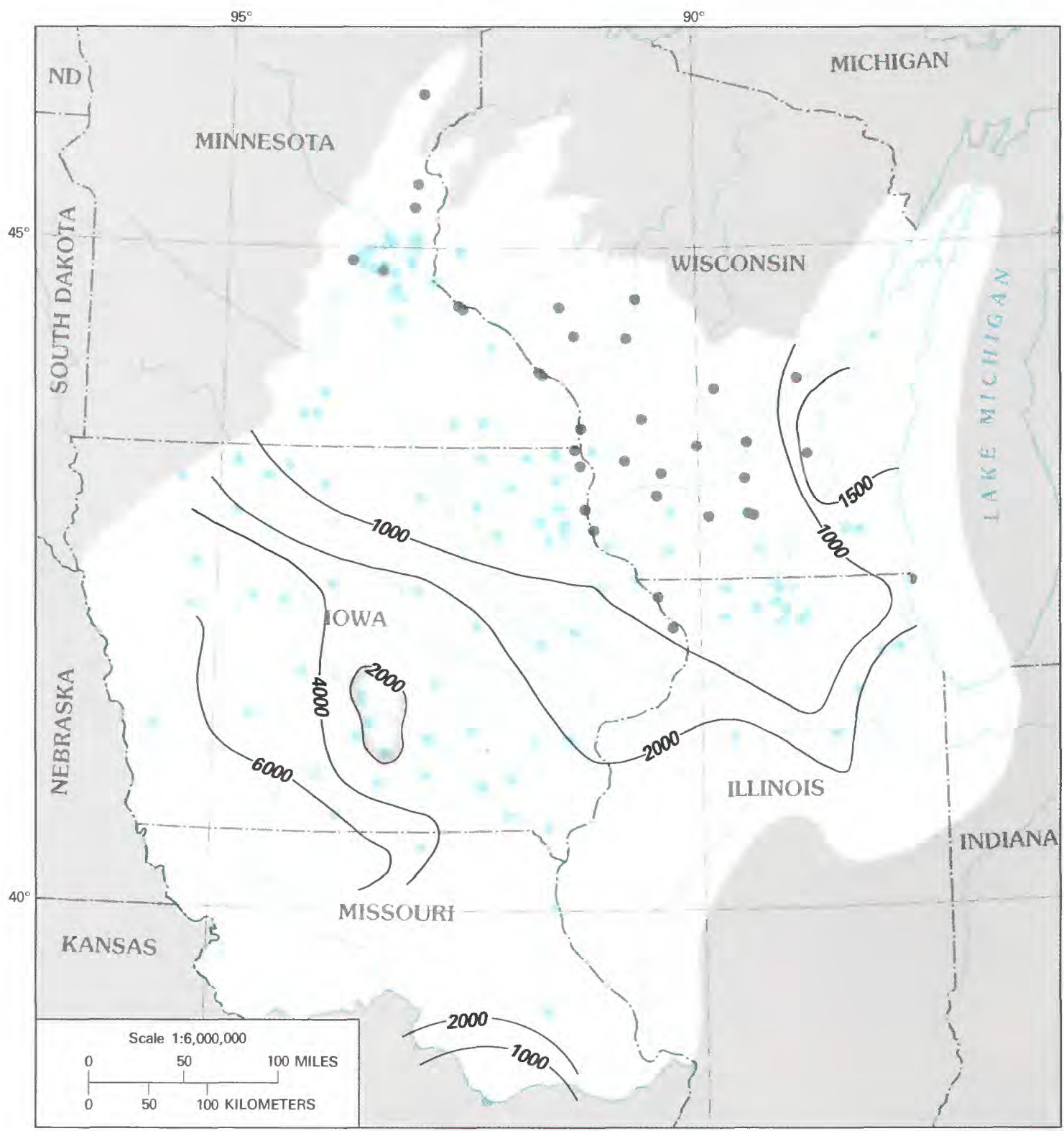

Base enlarged from U.S.Geological Survey

\section{EXPLANATION}

-1000 - LINE OF EQUAL DISSOLVED STRONTIUM CONCENTRATION - Stippled in direction of lower concentration. Interval, in micrograms per liter, is variable

WELL SAMPLED FOR CHEMICAL ANALYSIS DURING THIS STUDY

- Open to aquifer layer 1

Open to aquifer layer 3

Figure 27.-Distribution of dissolved strontium in aquifer layers 1 and 3. 


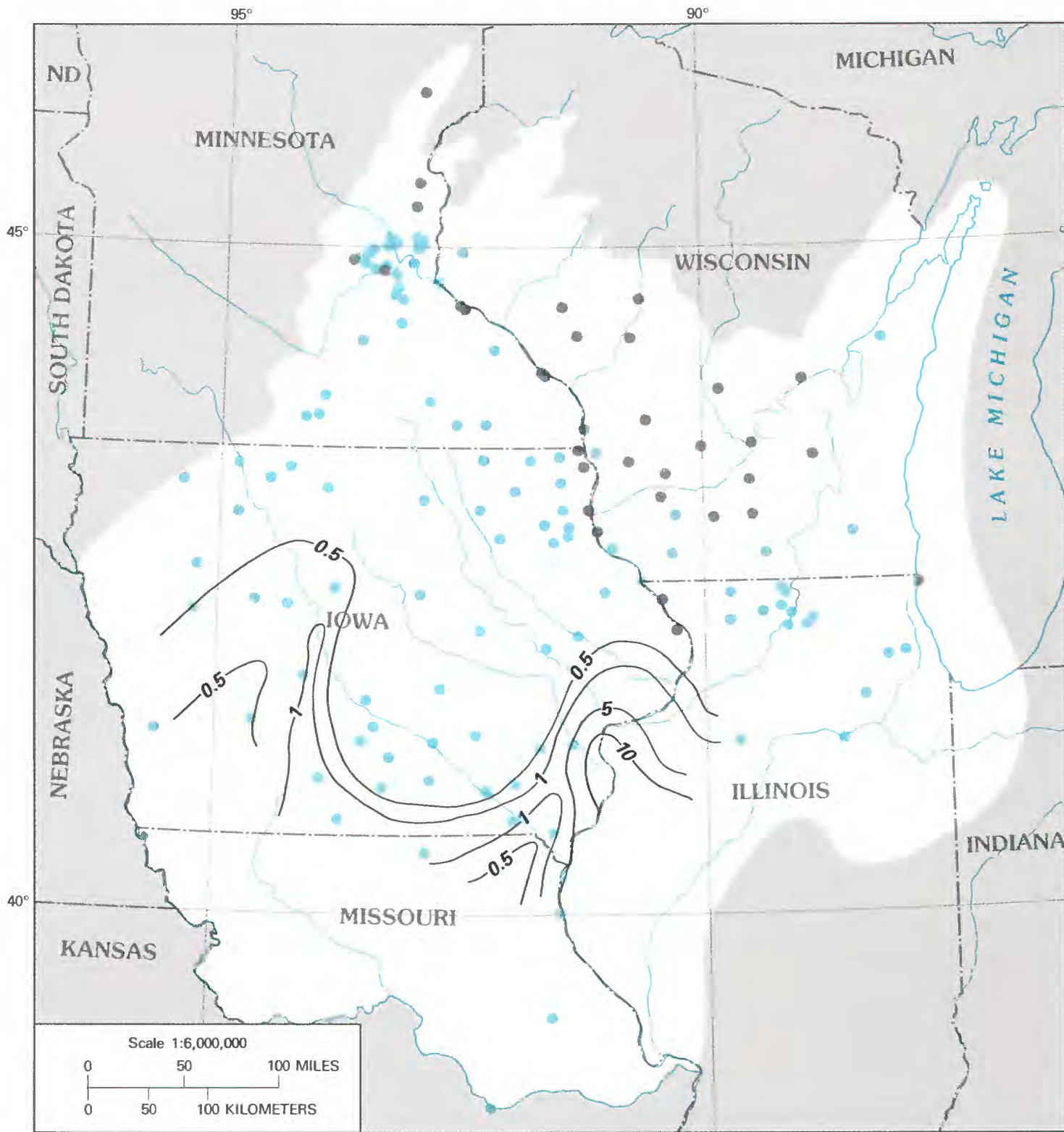

Base enlarged from

J.S.Geological Surv

EXPLANATION

\section{-5- LINE OF EQUAL BROMIDE CONCENTRATION - Interval, in milligrams per liter, is variable \\ WELL SAMPLED FOR CHEMICAL ANALYSIS DURING THIS STUDY \\ - Open to aquifer layer 1 \\ - Open to aquifer layer 3}

FIGURE 28.-Distribution of dissolved bromide in aquifer layers 1 and 3. 


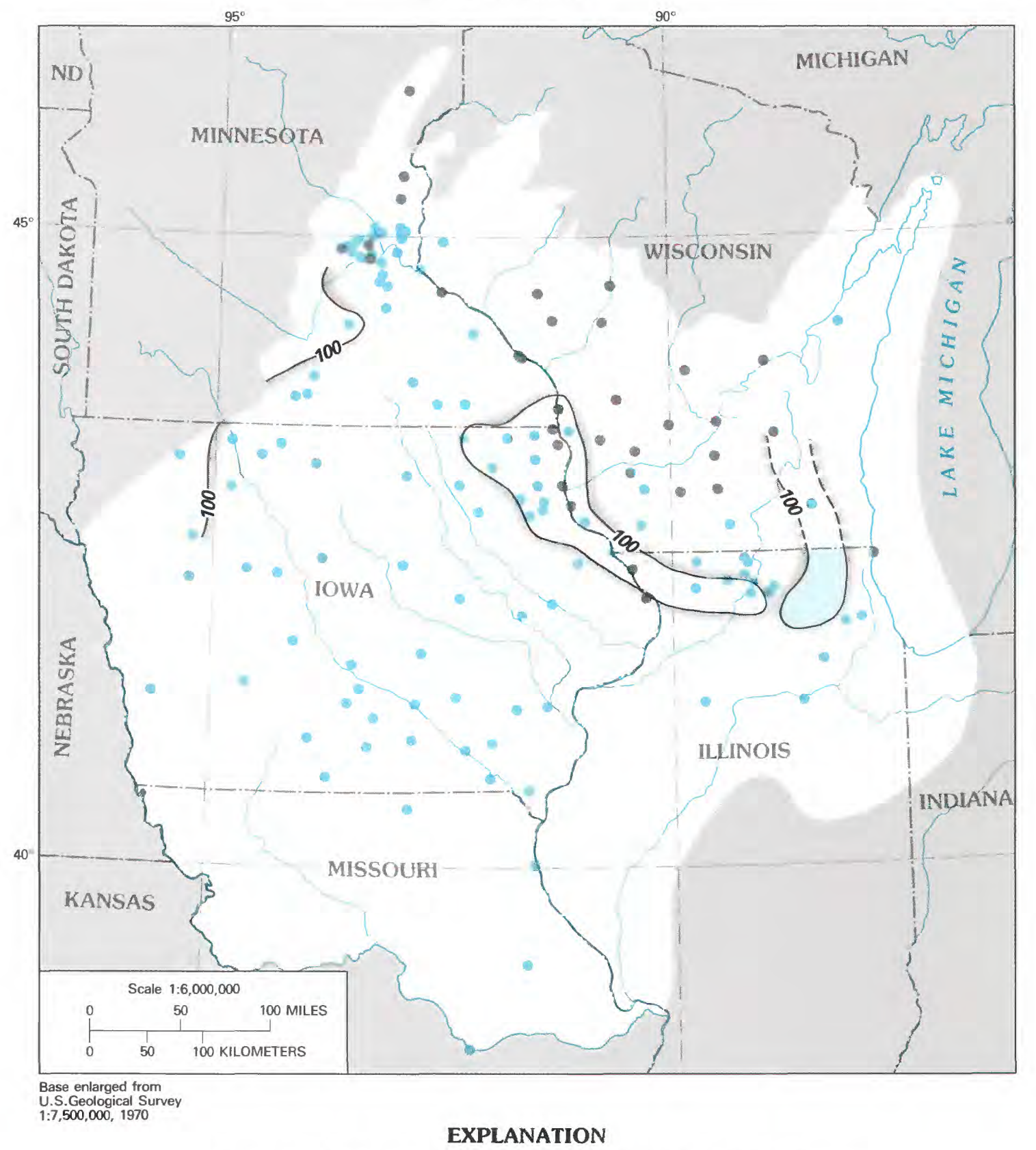

-100-- LINE OF EQUAL DISSOLVED BARIUM CONCENTRATION - Stippled in direction of lower concentration. Dashed where approximate. Interval 100 micrograms per liter

WELL SAMPLED FOR CHEMICAL ANALYSIS DURING THIS STUDY

- Open to aquifer layer 1

- Open to aquifer layer 3

DATA FROM GILKESON AND OTHERS (1981)

FIGURE 29.-Distribution of dissolved barium in aquifer layers 1 and 3. 


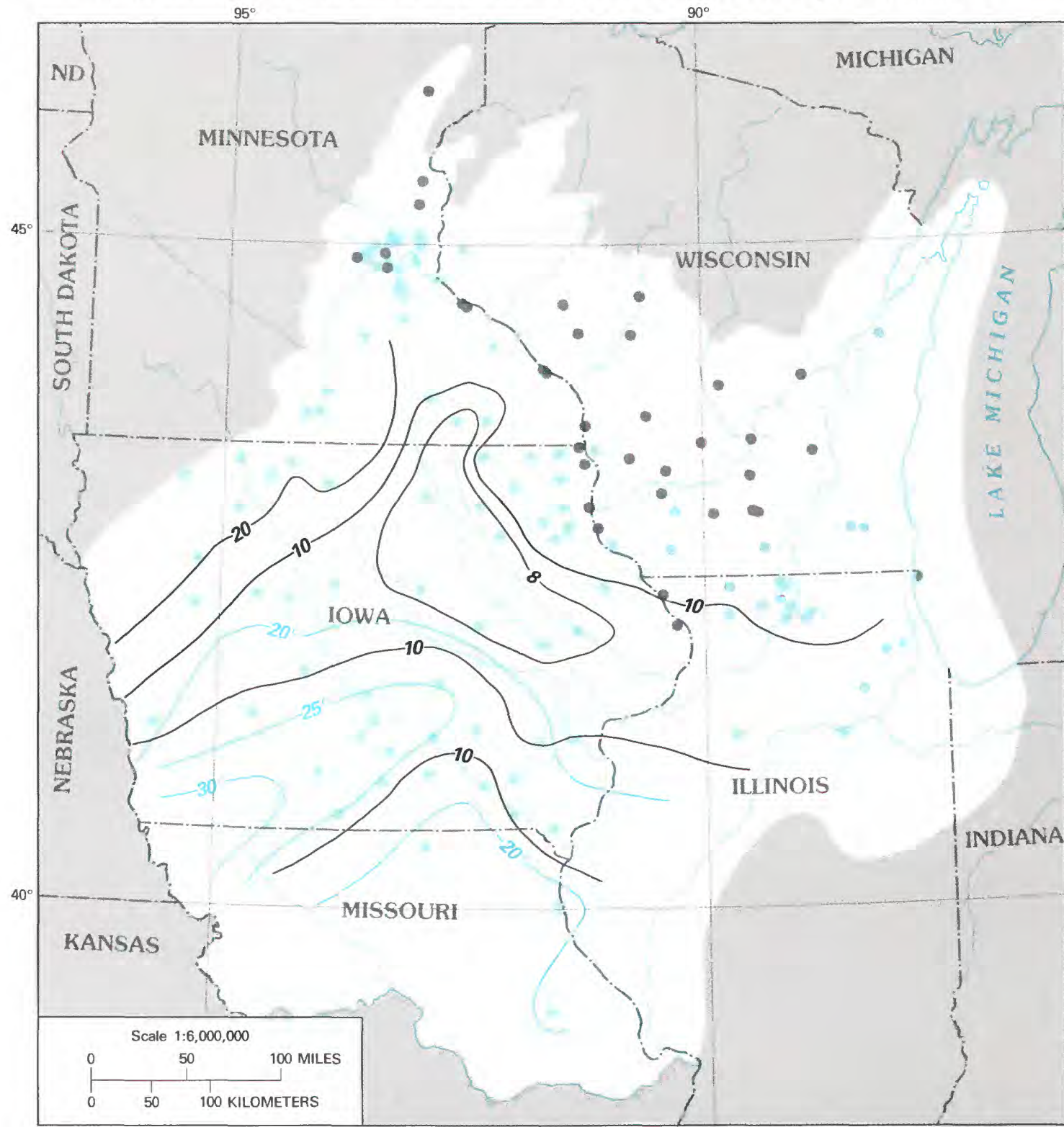

Base enlarged from

U.S.Geological Survey
$1: 7,500,000,1970$

EXPLANATION

- 20- LINE OF EQUAL DISSOLVED SILICA CONCENTRATION-Interval, in milligrams per liter, is variable

20 LINE OF EQUAL GROUND-WATER TEMPERATURE-Interval 5 degrees Celsius

WELL SAMPLED FOR CHEMICAL ANALYSIS DURING THIS STUDY

- Open to aquifer layer 1

Open to aquifer layer 3

Figure 30.-Distribution of dissolved silica and ground-water temperature in aquifer layers 1 and 3. 

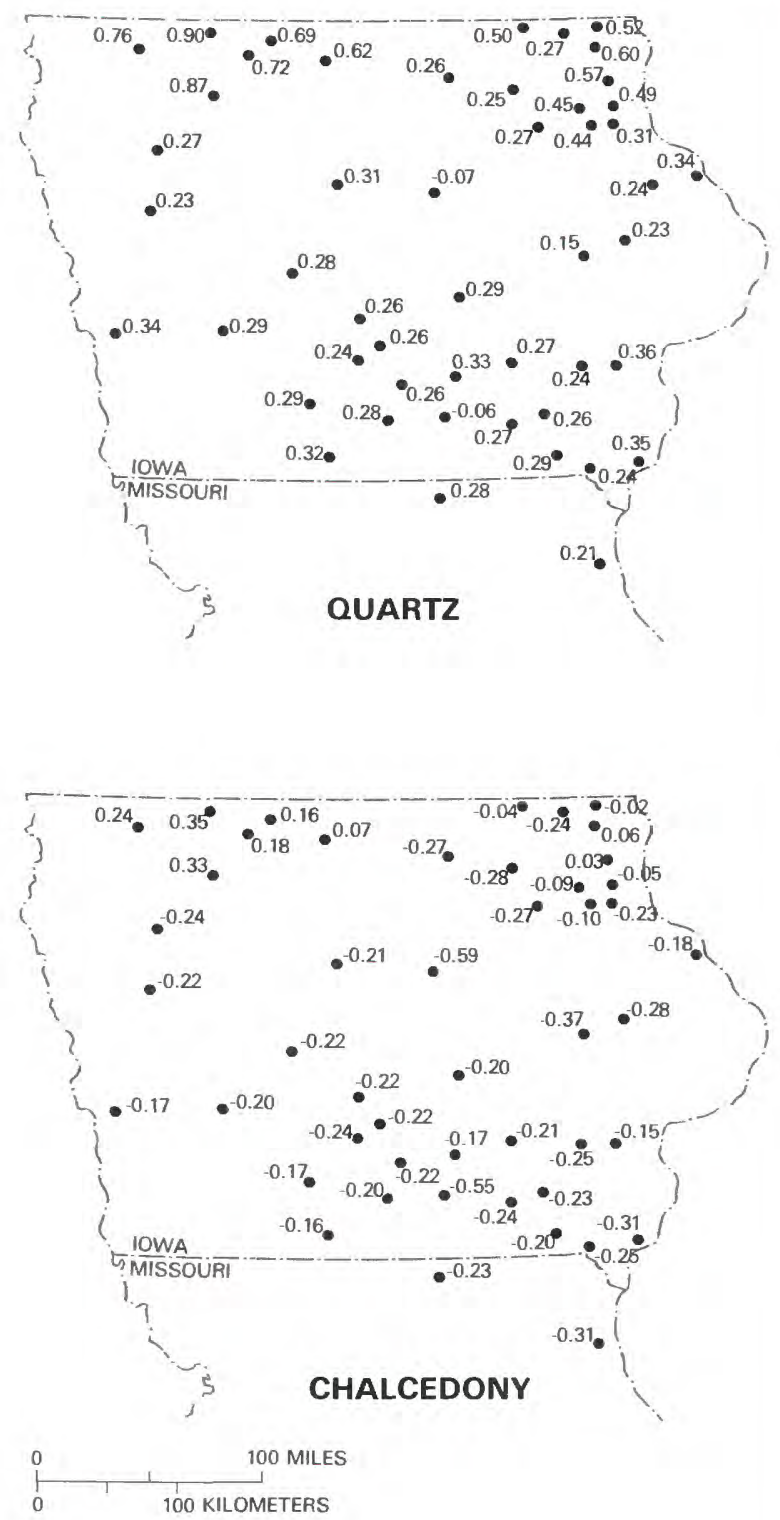

EXPLANATION

0.23. WELL LOCATION - Number is saturation index, $S I$ (see text for discussion)

Figure 31.-Saturation indices for quartz and chalcedony in water from selected wells in aquifer layer 3 in Iowa and northeastern Missouri.

Concentrations of silica in the aquifer system range from less than 8 to more than $20 \mathrm{mg} / \mathrm{L}$ (fig. 30). The differences in silica content are related to the solubility of silicate phases in the aquifer matrix. Saturation indices show oversaturation of quartz and undersaturation of chalcedony (fig. 31); this is a typical occurrence

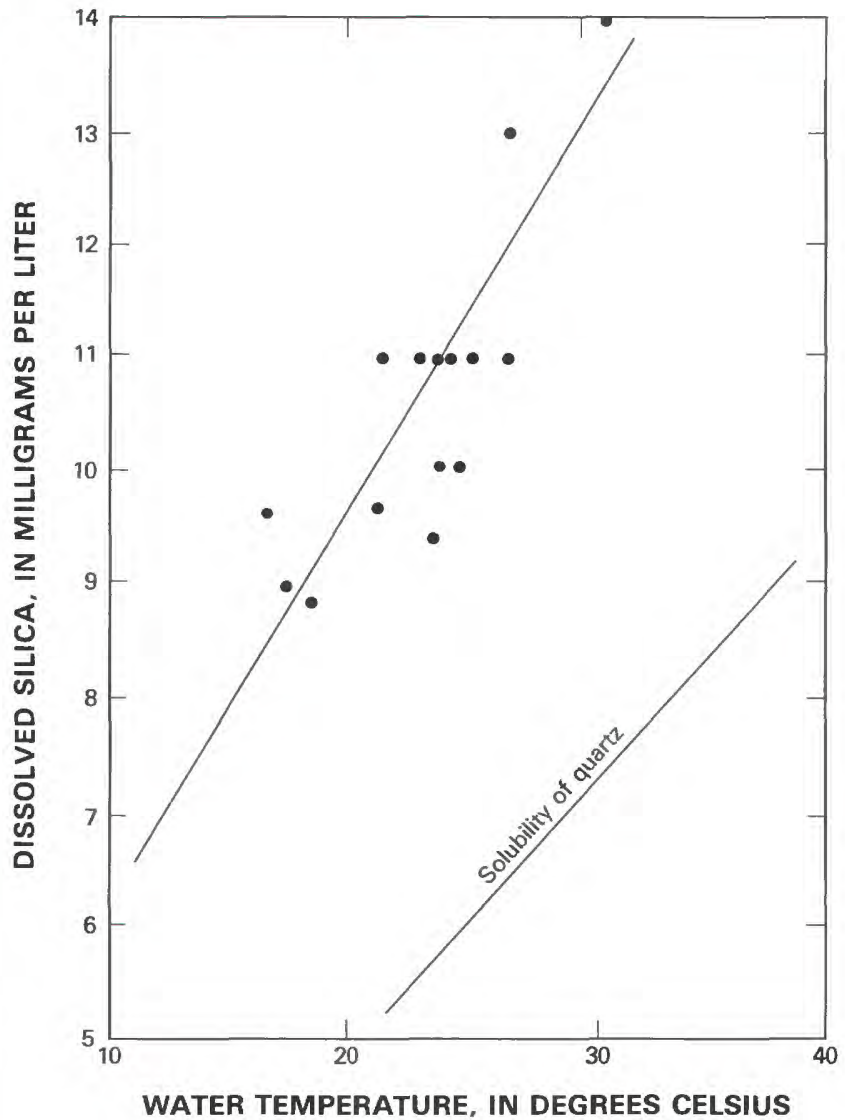

Figure 32.-Comparison of dissolved silica concentration and the solubility of quartz with water temperature in southwestern and southern Iowa and northeastern Missouri.

in many waters. The solubility of silica in surface and ground water is related to solid-phase products of aluminosilicate mineral dissolution, but no aluminum data are available to test the thermodynamic models of such dissolution in a formal sense.

Concentrations of silica greater than $20 \mathrm{mg} / \mathrm{L}$ are present in the recharge area in northwestern Iowa, where the Dakota Formation and the overlying drift contain siliceous shales. Concentrations decrease downgradient to less than $10 \mathrm{mg} / \mathrm{L}$ in central Iowa, increase to more than $10 \mathrm{mg} / \mathrm{L}$ in south-central Iowa, and then decrease to less than $10 \mathrm{mg} / \mathrm{L}$ in southeastern Iowa. The distribution patterns of silica and temperature are very similar, showing the direct relationship of silica solubility to water temperature. However, the data in figure 32 indicate that the relationship of quartz solubility with temperature is not the control on dissolved silica (Helgeson, 1969). This suggests that silica phases other than quartz are contributing silica to the ground water. 


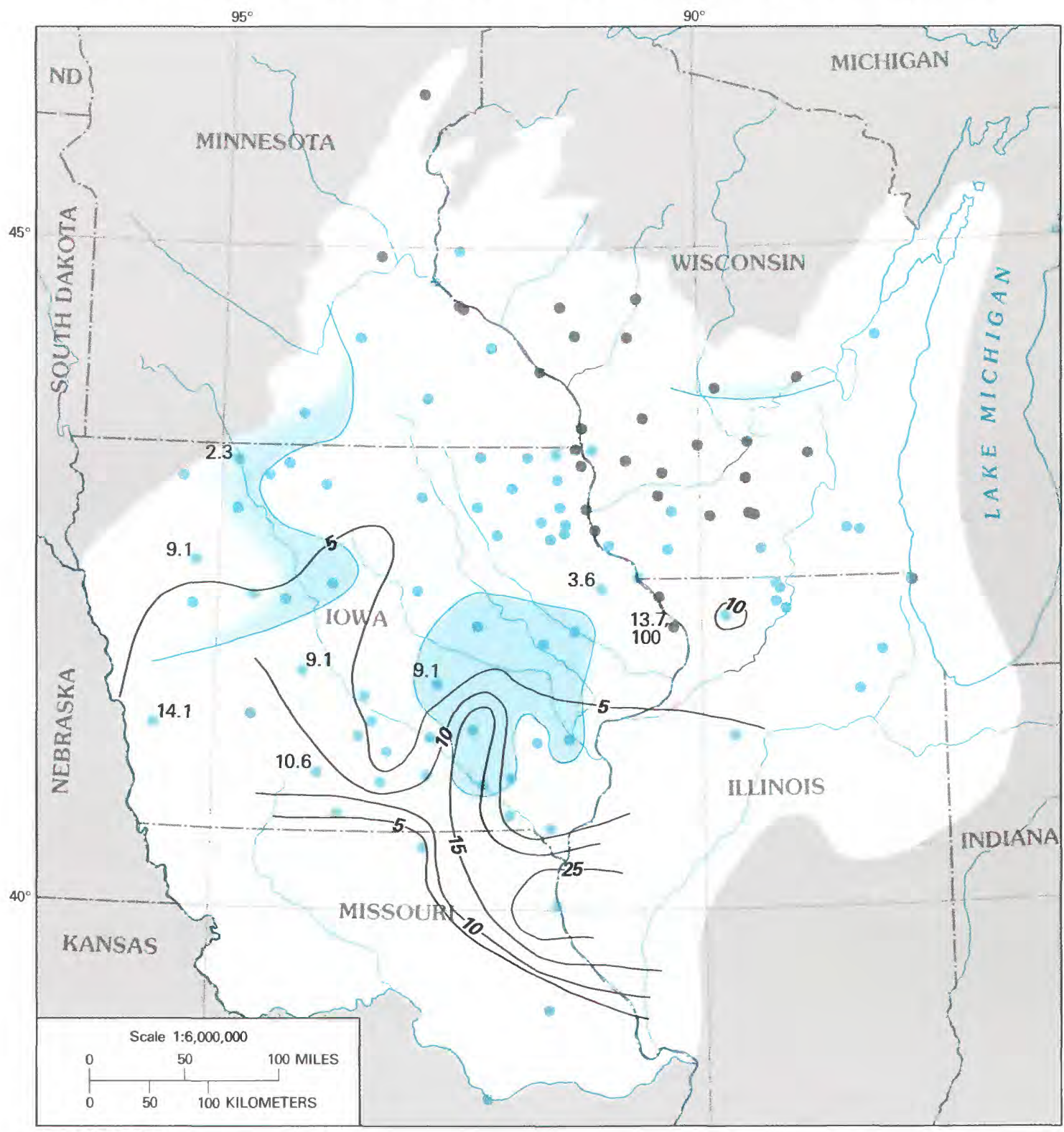

Base enlarged from $1: 7,500,000,1970$

EXPLANATION

-10- LINE OF EQUAL RADIUM-226 CONCENTRATION - Interval, in picocuries per liter, is variable

AREA WHERE DISSOLVED URANIUM CONCENTRATION EXCEEDS 1 MICROGRAM PER LITER

WELL SAMPLED FOR CHEMICAL ANALYSIS DURING THIS STUDY Number is activity ratio of ${ }^{234} \mathrm{U} /{ }^{238} \mathrm{U}$

13.7 Open to aquifer layer 1

9.1 Open to aquifer layer 3

Figure 33.-Distribution of dissolved uranium and radium-226 in aquifer layers 1 and 3. 
The distribution of uranium and radium-226 in the aquifer system shows the effects of the dilution plume in Iowa (fig. 33) on the concentration of these constituents. Uranium exceeds $1 \mu \mathrm{g} / \mathrm{L}$ in northwestern and southeastern Iowa but is less than $1 \mu \mathrm{g} / \mathrm{L}$ in central and southern Iowa and in northern Missouri in the vicinity of the plume of low dissolved solids. The $5-\mathrm{pCi} / \mathrm{L}$ line of radium-226 activity clearly defines the shape of the plume. Activity increases to more than $15 \mathrm{pCi} / \mathrm{L}$ southward near the Iowa-Missouri border, but the scant available data show a decrease to $5 \mathrm{pCi} / \mathrm{L}$ in northern Missouri.

High radium activities have been identified in Iowa (Brown and Morris, 1959; Lucas, 1960, 1985; Morris and Klinsky, 1962; Horick and Steinhilber, 1978; Cochran and Hahne, 1979), eastern Wisconsin (Lucas, 1960, 1985; Hahn, 1984), and northeastern Illinois (Lucas and Ilcewicz, 1958; Krause, 1959, 1960; Larson and Weatherford, 1960; Lucas, 1960, 1985; Emrich and Lucas, 1963; Kristoff and others, 1975; Gilkeson and Cowart, 1982; Gilkeson and others, 1983).

The sources of the high radium concentrations in the ground water are probably related to uranium-238 and thorium-232 in the aquifer matrix. These radioisotopes decay to radium-226 and 228, respectively. In Illinois, Gilkeson and others (1978) used radium-226 and radium-228 concentrations in 33 samples of Cambrian and Ordovician rocks to estimate the equivalent amounts of uranium-238 and thorium-232, assuming equilibrium between the parent-daughter nuclides. Calculated average uranium-238 concentrations ranged from about $1 \mathrm{ppm}$ in sandstone to about $3 \mathrm{ppm}$ in shale. Direct determinations of uranium-238 indicated that uranium-238 and radium-226 are in equilibrium or near equilibrium in the Cambrian-Ordovician rocks.

The activity of radium-226 and concentrations of uranium in solution may not be directly correlated, however, because of restraints on the solubility of uranium in different redox (reduction-oxidation) environments. Uranium is mobile in oxidizing environments and immobile in reducing environments (Hostetler and Garrels, 1962; Langmuir, 1978). Gilkeson and Cowart (1982) observed a decrease in total uranium concentrations from a few tenths $\mu \mathrm{g} / \mathrm{L}$ to less than $0.01 \mu \mathrm{g} / \mathrm{L}$ across a reduction front along a flow path in the Cambrian-Ordovician aquifer system in northeastern Illinois. Downgradient from the reduction front, however, uranium increased to more than $0.3 \mu \mathrm{g} / \mathrm{L}$ under oxidizing conditions. The decrease in uranium in the central part of Iowa also could be due partly to more reducing conditions along the major flow paths. The increase in uranium in southeastern Iowa, however, probably is not caused by increased uranium solubility in oxidizing conditions, because other chemical constit- uents, such as dissolved sulfide, indicate probable reducing conditions.

Radium-226 activity can be increased in the ground water along a reducing front because of decay of uranium in the water and uranium previously precipitated in the aquifer matrix. The decrease in uranium in Iowa is not accompanied by an increase in radium-226 from northeast to southwest. Therefore, concentrations of uranium and radium-226 in central Iowa seem to be related more to the dilution events than to geochemical processes in the aquifer system.

The activity ratio of ${ }^{234} \mathrm{U} /{ }^{238} \mathrm{U}$ generally increases across a reducing front because of alpha-recoil transfer (Kronfeld and others, 1975; Cowart and Osmond, 1977). No such increase in the activity ratio is apparent from the data in central Iowa. However, to relate redox relationships to uranium and radium in ground water, more detailed sampling is necessary at a closer spacing than for the reconnaissance purposes of this study. Defining sources and sinks for radium and uranium in the study area would require more detailed information on the concentrations and isotopic variability of these constituents and thorium in aquifer matrices and ground water. For example, in a more detailed study, Gilkeson and Cowart (1982) determined ${ }^{234} \mathrm{U} /{ }^{238} \mathrm{U}$ alpha-activity ratios in ground water from the aquifer system along a flow path from the unconfined to confined system in northeastern Illinois. Where the aquifer is confined by the Maquoketa Shale, ratios exceed 20, but in the unconfined area, ratios are generally less than 5 . The disequilibrium in the confined area is pronounced, and Gilkeson and Cowart (1982) suggest that dissolved uranium was emplaced in the aquifer during Pleistocene glaciation when flow directions may have been different from those of today. Uranium-234 could then have been leached from glacial till and the Maquoketa Shale. However, the observed disequilibrium still is problematical, because the role of geochemical and radiogenic mechanisms in enriching the isotopic ratio is not fully understood (Gilkeson and others, 1978).

Similar disequilibria are found in selected samples of water from aquifer layer 3 in Iowa. ${ }^{234} \mathrm{U} /{ }^{238} \mathrm{U}$ activity ratios determined from a few selected water samples showed disequilibrium and range from 2.3 to 14.1 with no discernible pattern (fig. 33). For example, the ratio is 9.1 for water in the northwest recharge area associated with the Dakota Formation as well as for water in the central dilute plume area. The scant data suggest that the ratio in Iowa increases generally toward the south, but additional data are needed to verify the trend.

A water sample from a 2,673-ft-deep test well drilled during this study at Green Island in extreme eastern Iowa is of particular interest. The sample from the interval 1,741 to $2,673 \mathrm{ft}$ in the Mount Simon Sand- 
stone had the extraordinarily high ratio of 100 (fig. 33). This may be the largest known uranium disequilibrium in an aquifer system. Gilkeson and Cowart (1982) indicate that the highest reported ratio prior to their work was 12.3 . They measured activity ratios as high as 28.6 in the Cambrian-Ordovician aquifer system in northeastern Illinois and activity ratios "greater than 40 " in the aquifer system in other parts of Illinois.

Gilkson and Cowart (1982) hypothesize that such extreme disequilibrium may be related to influx of uranium-234-enriched uranium derived from fine-grained materials during the emplacement of glacial meltwater during the Pleistocene. The uranium-234enriched ground water could be further enriched by isotopic fractionation caused by precipitation of the uranium in the reducing zone downgradient from the meltwater recharge front. Unfortunately, the scant areal distribution of the uranium isotope data for this study is not sufficient to evaluate this hypothesis further, and the causes of the isotopic enrichment are still unknown.

\section{ISOTOPIC COMPOSITION OF WATER AND} PLEISTOCENE RECHARGE MODEL

The direction of the dilute plume, from northeastern Iowa to south-southwestern Iowa, suggests a flow system having recharge areas in southeastern Minnesota and northeastern Iowa and discharge areas in Missouri or farther south. The study region was glaciated numerous times during the Pleistocene Epoch. Work by Boellstorff $(1976,1980)$ indicates that at least Nebraska and Iowa were glaciated as long ago as $2.5 \mathrm{~m} . \mathrm{y}$. (million years) and that the classic Nebraskan-Kansan sequence of glaciation-now referred to as Pre-Illinoian (Richmond and Fullerton, 1986)-occurred 1.0 to 0.4 m.y. ago. At least five ice advances occurred in Iowa and Nebraska during this time. No similar sequence of glaciation has been identified in Wisconsin and Illinois to date, but evidence of such glaciation could be obscured by glaciation during Illinoian and Wisconsin time, from about 100,000 to $12,000 \mathrm{yr}$ B.P. (years before present).

The extent of major glaciations (fig. 34) has been estimated from the stratigraphic relationships among glacial deposits (Flint, 1972). Pre-Illinoian advances extended almost to the Missouri River and covered much of the study area. Later advances during Illinoian time covered most of Illinois and parts of Wisconsin. During Wisconsin time, numerous ice lobes advanced into Wisconsin, Minnesota, Iowa, and Illinois.

Theoretical reconstructions of the temperature distribution in continental Pleistocene glaciers have indicated that a pressure-melting zone probably was exten- sive in the basal part of the ablation zone. The zone may have extended upgradient for a few hundred miles from frozen ice margins (Hooke, 1977; Sugden, 1977; Moran and others, 1980). Glacial movement in these unfrozen areas involved basal sliding (Weertman, 1957, 1961, 1964; Clayton and Moran, 1974). Landforms such as drumlins, tunnel valleys, and streamlined ridges are field evidence for basal melting (Wright, 1973; Clayton and Moran, 1974; Moran and others, 1980) where meltwater under high hydrostatic head could have recharged the Cambrian-Ordovician aquifer system in outcrop areas.

The isotopic composition of oxygen and hydrogen in the ground water in the aquifer system is important geochemical evidence for such recharge. The distribution of $\delta^{18} \mathrm{O}$ and $\delta \mathrm{D}$ in modern precipitation shows excellent covariation with both mean annual air temperature and latitude because of isotope fractionation by the Raleigh distillation effect (Dansgaard, 1964). Covariation between $\delta^{18} \mathrm{O}$ and $\delta \mathrm{D}$ of modern precipitation defines an average meteoric water line (Craig, 1961), expressed as

$$
\delta \mathrm{D}=8 \delta^{18} \mathrm{O}+10,
$$

to which the isotopic content of ground water can be compared. If past ground-water recharge occurred under climatic conditions similar to those of today, then the isotopic composition of the ground water should be similar to that of modern recharge. However, if the ground water originally precipitated at temperatures colder than today, its isotopic composition should be lighter than modern recharge but should still plot near the meteoric water line (eq. 13). Deviations of the data from the trend of the line indicate that geochemical processes, such as water-rock interaction, evaporation, or ultrafiltration, have modified the isotopic composition of the water.

The relationship of $\delta^{18} \mathrm{O}$ to $\delta \mathrm{D}$ in ground water in the Cambrian-Ordovician aquifer system exclusive of the Illinois basin is similar to the isotopic composition of modern precipitation (fig. 35). This indicates that the water in the Cambrian-Ordovician aquifer system outside the Illinois basin retains its meteoric nature and has been relatively unaltered by significant reactions with the aquifer matrix. Water in the Illinois basin is enriched in oxygen-18 because of probable exchanges between carbonate rock and water at temperatures more than twice the temperature in the fresher and shallower parts of the aquifer system (Clayton and others, 1966). The average $\delta^{18} \mathrm{O}$ and $\delta \mathrm{D}$ of modern precipitation in the study area ranges from about -8 to $-6 \%$ and from -70 to $-50 \%$, respectively, from 


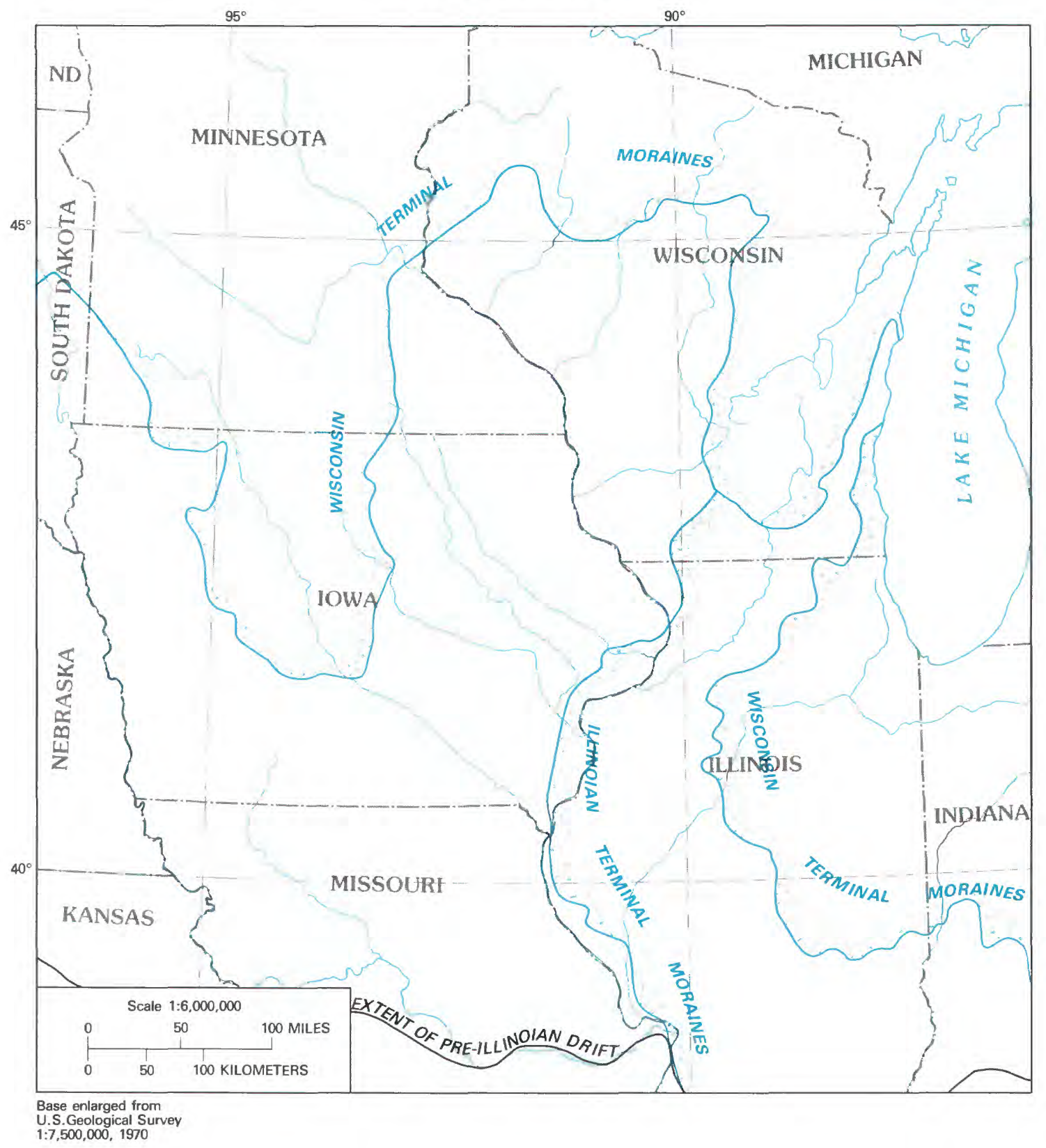

Figure 34.-Extent of major glaciations in the northern Midwest during the Pleistocene Epoch.

north to south (Yurtsever, 1975). The difference in $\delta^{18} \mathrm{O}$ and $\delta \mathrm{D}$ between water in the aquifer and in modern precipitation, as much as -9 and $-70 \%$ oo, respectively, indicates past recharge to the aquifer system that is isotopically similar to water now precipitated at colder latitudes hundreds of miles north of the study area. No shift occurs in the isotopic content of water across the Holocene-Pleistocene boundary in regional aquifers unaffected by glaciation (Hanshaw and others, 1978). This suggests that the light isotopic composition of the ground water is not a result of continental differences in the isotopic composition of interstadial precipitation.

Isotopically light ground water in the aquifer system in northern Illinois has been described previously and explained as Pleistocene recharge (Clayton and others, 1966; Gilkeson and others, 1981; Perry and others, 1982). Regional distribution of the isotopic composition of water in the aquifer system (figs. 36,37 ) closely approximates the distribution of dissolved solids (fig. 


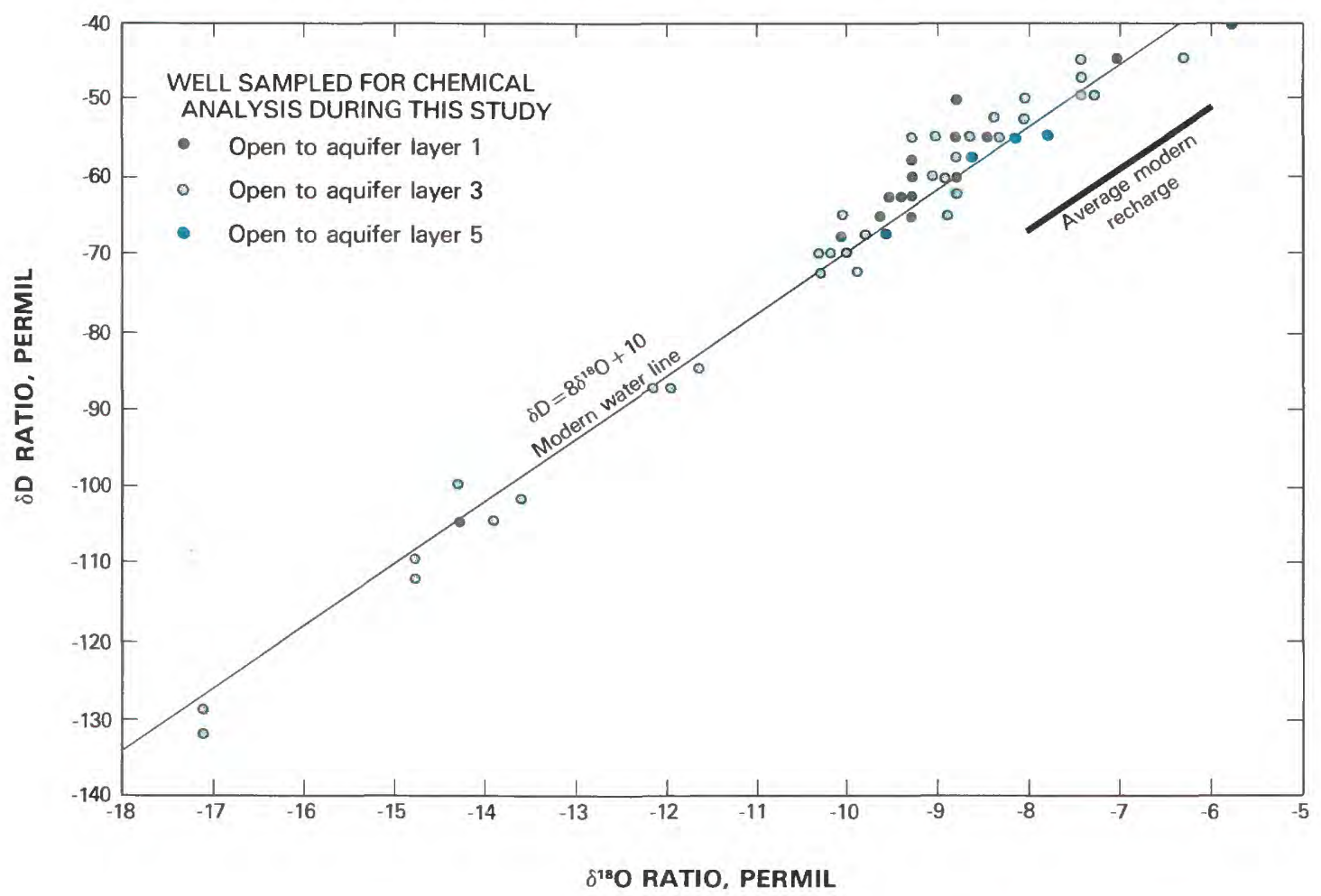

Figure $35 .-\delta^{18} \mathrm{O}-\delta \mathrm{D}$ relationship for ground water in the northern Midwest.

7). In Iowa and Missouri, ground water is isotopically lighter toward the south, approximately perpendicular to the direction of the modern hydraulic gradient. The boundary of the dilute plume in central Iowa is coincident with the $-10 \%$ oo $\delta^{18} \mathrm{O}$ isoline. The plume, although isotopically about 2 to $4 \%$ oo lighter with respect to $\delta^{18} \mathrm{O}$ than modern recharge at the same latitude, is isotopically heavier than surrounding ground water. The extension of the $-10 \%$ line into south-central Iowa and the distribution of dissolved solids suggest a ground-water flow direction approximately perpendicular to that of today.

The $\delta^{18} \mathrm{O}$ content of North American ice sheets could have ranged from about $-40 \%$ oo (Dansgaard and Tauber, 1969) to -9 \%oo (Emiliani, 1971). Yapp and Epstein (1977), using calculations from $\delta$ D of cellulose in plant material entrained in drift, suggest an intermediate $\delta^{18} \mathrm{O}$ of $-15 \%$ oo for the ice of the latest Wisconsin advance. If the isotopically lightest water in the aquifer system in southern Iowa were emplaced during this time, virtually all the ground water in the southwestern part of the study area would be recharged from glacial meltwater. This is unlikely because the dissolution of carbonate and silicate minerals at aquifer temperatures (less than $40{ }^{\circ} \mathrm{C}$ ) would not produce concentrations of dissolved solids exceeding $2,500 \mathrm{mg} / \mathrm{L}$ or the large equivalent percentages of chloride and sodium found in the southwestern part of the aquifer. Therefore, the isotopic content of the ground water probably represents a mixture of meltwater with $\delta^{18} \mathrm{O}$ depleted to less than $-17 \%$ and pre-Pleistocene ground water with $\delta^{18} \mathrm{O}$ enriched to more than $-17 \%$, and perhaps similar to the isotopic content of modern recharge.

The shape of the dilute plume looks similar to the shape of the Des Moines lobe which covered part of north-central Iowa during the last advance of Wisconsin ice. This suggests that the plume may be related to this ice advance. The isotopic content of water in the dilute plume would be lighter than $-10 \%$ oo if the plume were caused by meltwater recharge under the lobe through the outcrop area in southern Minnesota. However, the possible displacement of ground water having low dissolved solids from overlying Paleozoic aquifers to aquifer layer 3 by vertical leakage of subglacial meltwater cannot be ruled out unequivocally at this time.

Scant data indicate that dissolved-solids concentrations in aquifer layer 4 are generally more than 1,000 $\mathrm{mg} / \mathrm{L}$ where the aquifer is overlain by Mississippian rocks in central Iowa but are generally less than 500 $\mathrm{mg} / \mathrm{L}$ in outcrop areas north of the Mississippian erosional edge (U.S. Geological Survey, unpub. data). 


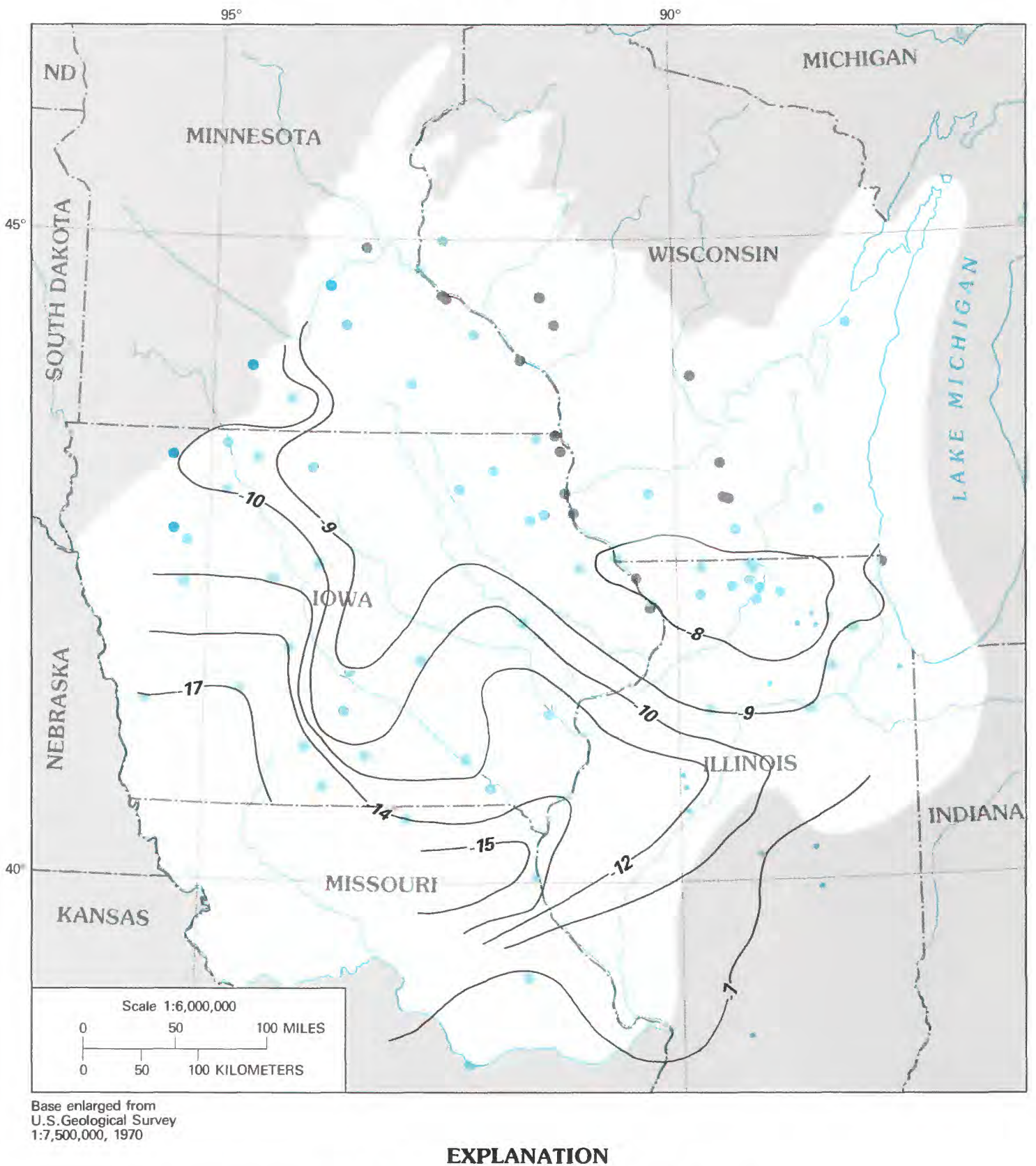

- 8 - LINE OF EQUAL $\delta^{18}$ O RATIO - Interval, permil, is variable

WELL SAMPLED FOR CHEMICAL ANALYSIS DURING THIS STUDY

Open to aquifer layer 1

Open to aquifer layer 3

Open to aquifer layer 5

WELL WITH ANALYSIS FROM OTHER SOURCE

Open to aquifer layer 3

Figure 36.-Distribution of $\delta^{18} \mathrm{O}$ ratio in aquifer layers 1,3 , and 5. 


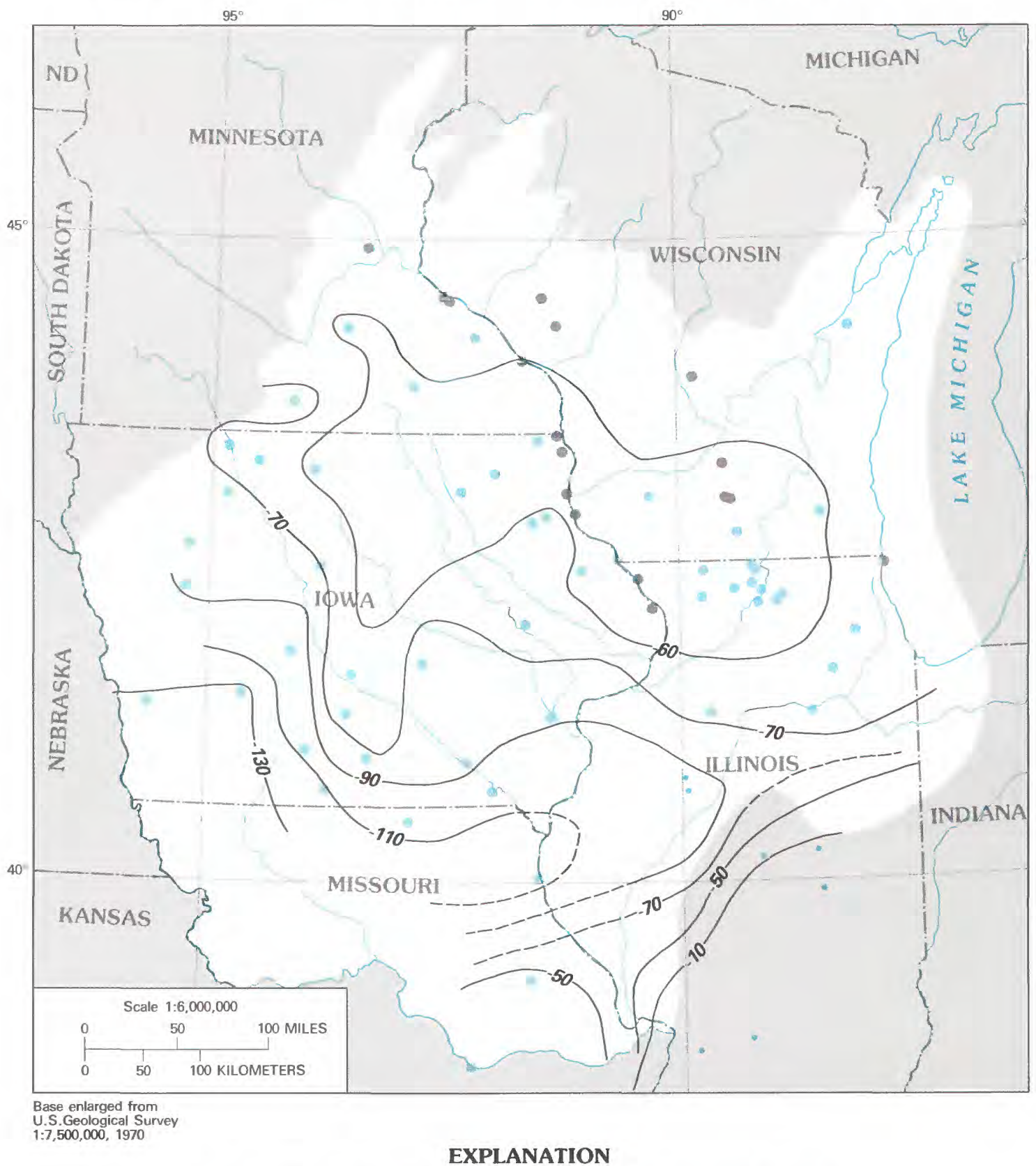

--70 - LINE OF EQUAL $\delta$ D RATIO-Dashed where approximate. Interval,
permil, is variable

WELL SAMPLED FOR CHEMICAL ANALYSIS DURING THIS STUDY

- Open to aquifer layer 1

Open to aquifer layer 3

WELL WITH ANALYSIS FROM OTHER SOURCE

Open to aquifer layer 3

Figure 37.-Distribution of $\delta$ D ratio in aquifer layers 1 and 3. 


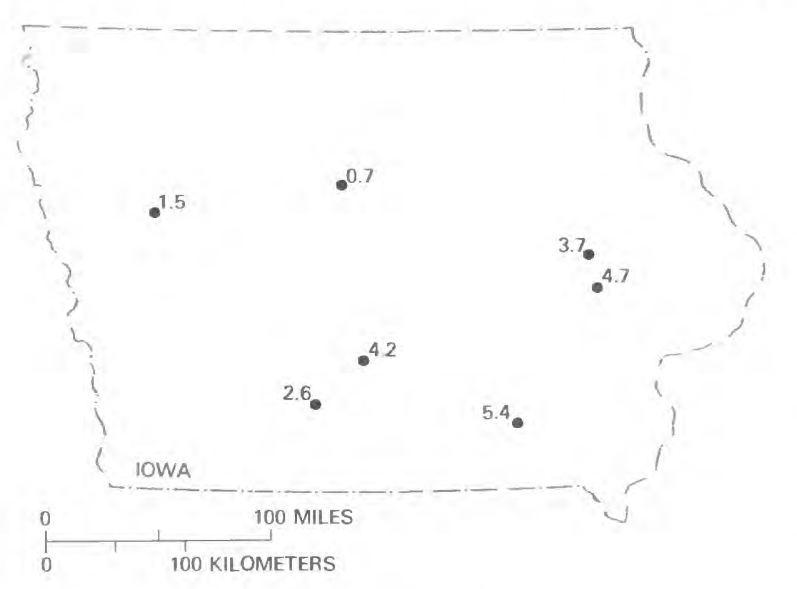

EXPLANATION

1.5. WELL LOCATION - Number is percent modern carbon in dissolved carbonate

Figure 38.-Carbon-14 data for water from selected wells in aquifer layer 3 in Iowa.

Dissolved-solids concentration in ground water from Mississippian rocks in north-central Iowa is more than $500 \mathrm{mg} / \mathrm{L}$. The $1,000-\mathrm{mg} / \mathrm{L}$ isoline of dissolved solids in the Mississippian rocks roughly outlines a dilute plume trending from north-central to southwestern Iowa (Horick and Steinhilber, 1973), similar to the plume in aquifer layer 3.

Downward movement of meltwater from the base of the Des Moines lobe into the Mississippian rocks could have started a series of downward displacements of water from layer to layer: recharge of water with low dissolved solids into the Mississippian; higher disolvedsolids water (more than $1,000 \mathrm{mg} / \mathrm{L}$ ) from the Mississippian into aquifer layer 4; and water with low dissolved solids from aquifer layer 4 into aquifer layer 3 , forming the dilute plume. Water in aquifer layer 4 could have had a $\delta^{18} \mathrm{O}$ content ranging from -8 to $-6 \%$ oo if it were not mixed with meltwater recharge from previous glaciations. Downward flow of water from aquifer layer 4 to aquifer layer 3 could have resulted in both dilution and isotopic enrichment. However, additional isotopic data for ground water from aquifer layer 4 and the Mississippian in central Iowa are needed to evaluate better the influence of the Des Moines lobe on the Cambrian-Ordovician aquifer system.

The time, or times, of meltwater emplacement is unknown. Seven carbon-14 analyses of ground water from aquifer layer 3 in Iowa have a range of 0.7 to 5.4 percent modern carbon (fig. 38). These values correspond to apparent ages ranging from more than 30,000 to about 15,000 yr B.P., respectively, corrected for isotopic dilution by dissolution of carbonate aquifer minerals. The smallest amount of modern carbon occurs in central Iowa within the dilute plume. This could reflect either the age of water in aquifer layer 3 or a composite age of water from aquifer layers 3 and 4 , if vertical recharge occurred beneath the ice of the Des Moines lobe. A small amount of modern carbon may have been introduced in the sampling procedure at other sites as contamination from atmospheric carbon dioxide (E.C. Alexander, University of Minnesota, written commun., 1982; L.N. Plummer, U.S. Geological Survey, oral commun., 1982). Water in aquifer layer 1 at St. Paul, Minn., has an apparent age of more than 35,000 yr B.P. (Alexander and others, 1983), and very likely water in the Cambrian-Ordovician aquifer system in southern Iowa and northern Missouri also contains little or no measurable carbon-14 because flow paths are many times longer than in Minnesota.

The possible emplacement of meltwater during the late Pleistocene was independently tested using the steady-state three-dimensional ground-water flow model of Mandle and Kontis (in press) to simulate the Cambrian-Ordovician aquifer system under the pressure head caused by the weight of the glacial ice about $18,000 \mathrm{yr}$ B.P. The head values for the water-table aquifer (aquifer layer 5) in the ice-covered areas (fig. 39) were estimated as the sum of the elevation head at the land surface and the pressure head from the ice. The water-table aquifer is represented by constant-head nodes in the model and provides the hydraulic driving force to simulate ground-water flow. An average Wisconsin glacial ice-sheet configuration was assumed similar to that described by Denton and Hughes (1981). The static steady-state topography of the ice sheets at maximum advance calculated by Denton and Hughes (1981) was based on the modern analog of the Greenland and Antarctic ice sheets. This may be incorrect because geologic evidence suggests that the Laurentide ice sheet did not attain a steady-state profile everywhere but may have been highly dynamic (Clark, 1980; Andrews, 1982). Nevertheless, the Denton and Hughes (1981) model is probably a first approximation for the general morphometry of the major ice lobes that entered the northern Midwest during Wisconsin time. Hydraulic parameters, boundaries, and nodal distribution for all aquifer layers were those used in a steady-state flow model of the modern Cambrian-Ordovician aquifer system described by Mandle and Kontis (in press). The position of the ancestral Mississippi River was assumed to be similar to its present position. Although the ancestral Mississippi River was displaced in some areas during the late Pleistocene, the displacement did not significantly alter the general drainage pattern from 


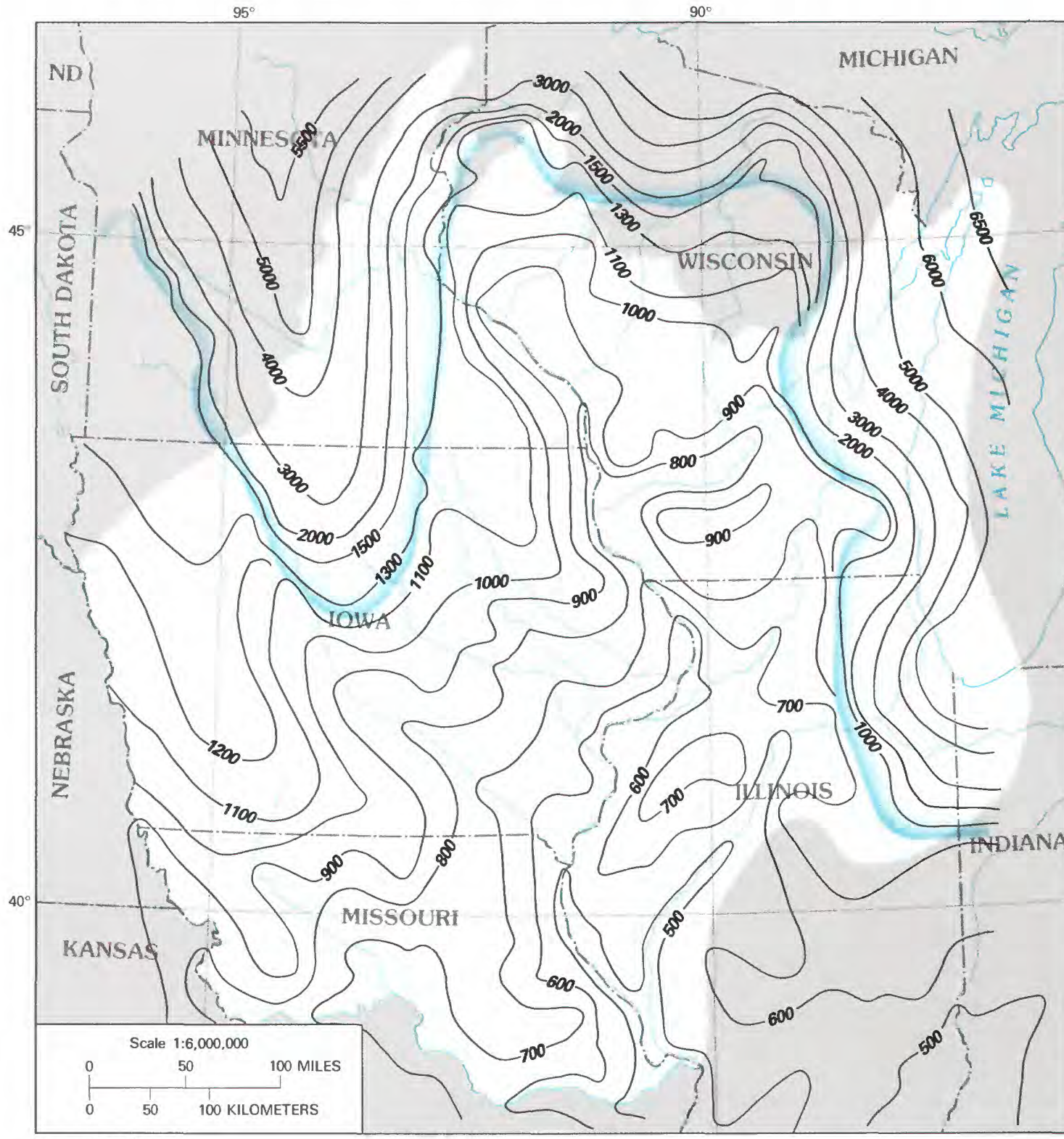

Base enlarged from $1: 7,500,000,1970$

\section{EXPLANATION}

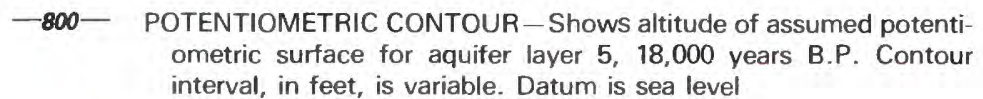
interval, in feet, is variable. Datum is sea level

APPROXIMATE ICE MARGIN

FIGURE 39.-Assumed hydraulic head for aquifer layer 5 incorporating effects of ice thickness at the average advance of ice, about $18,000 \mathrm{yr}$ B.P., during late Wisconsin time.

north to south near the border of Iowa and Illinois (Flint, 1972).

Results of the steady-state flow model show that the distribution of ice at the average Wisconsin advance probably did not significantly change the direction of ground-water flow in most of Iowa and Missouri (fig. 40). Ground-water flow paths, in general, were from northwestern Iowa southeastward to the Illinois basin. 


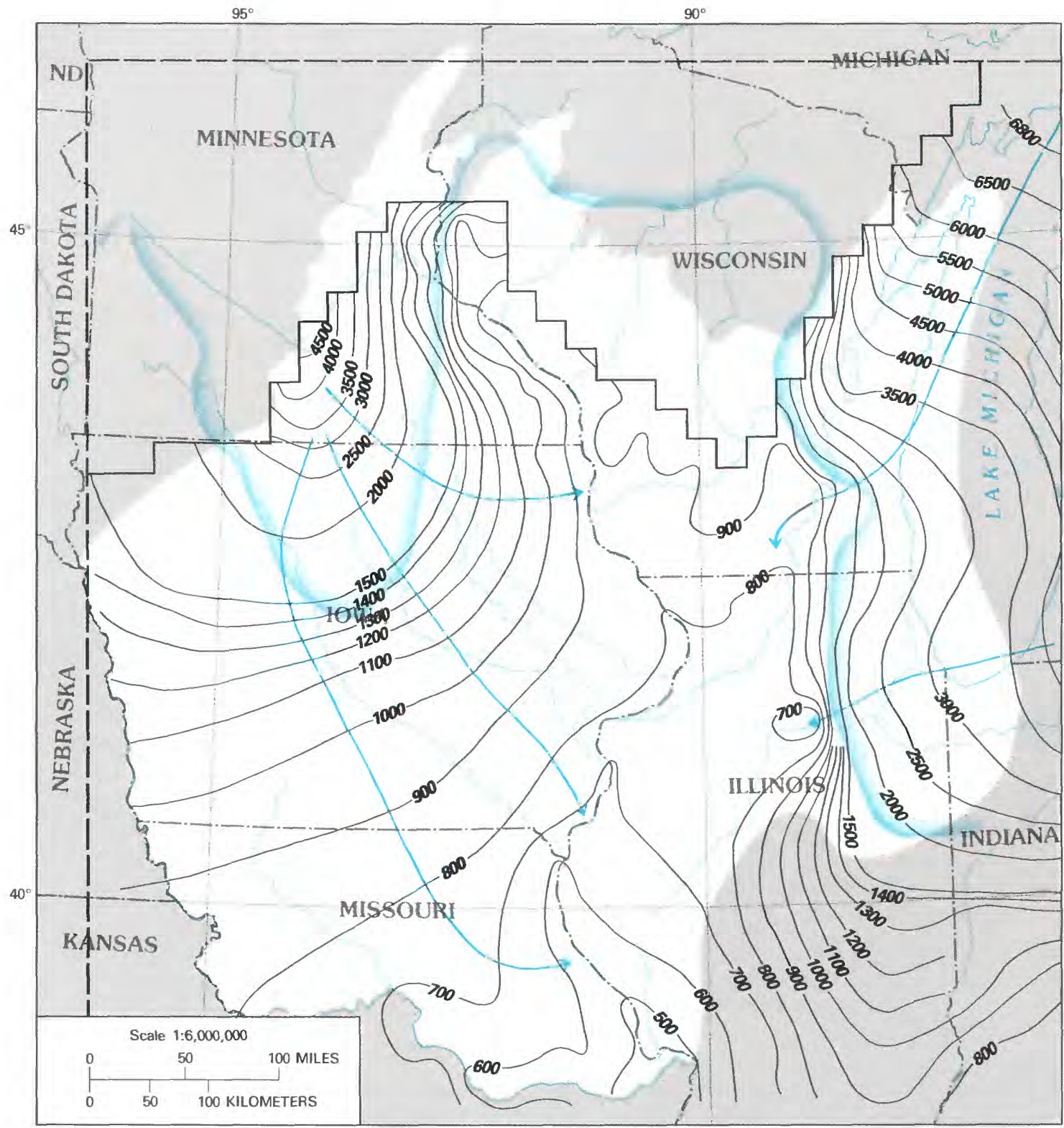

Base enlarged from U.S. Geological Survey
$1: 7,500,000,1970$

EXPLANATION

-900- POTENTIOMETRIC CONTOUR - Shows altitude of simulated potentiometric surface for aquifer layer 3, 18,000 years B.P. Contour interval, in feet, is variable. Datum is sea level

APPROXIMATE ICE MARGIN

$\longrightarrow$ GENERALIZED GROUND-WATER FLOW PATH

MODELED LAYER 3 BOUNDARY

- BOUNDARY OF GROUND-WATER FLOW MODEL

FIGURE 40.-Simulated hydraulic head in aquifer layer 3 at the average advance of ice, about 18,000 yr B.P., during late Wisconsin time. 
Some ground-water flow was diverted from central to northeastern Iowa from a local ground-water divide that is symmetrical with the axis of the Des Moines lobe in Iowa. In eastern Wisconsin and Illinois, simulated ground-water flow was opposite from that of today: ground-water recharge zones were in the vicinity of Lake Michigan, and discharge zones were the outcrop areas in Wisconsin, northeastern Iowa, southeastern Minnesota, and northern Illinois. Results of the flow model show that, during late Wisconsin time, the net movement of ground water was not in the direction of the dilute plume, from northeastern to southwestern Iowa. Much of the outcrop area of the aquifer in Wisconsin, Iowa, and Illinois was probably a discharge zone, as suggested by the results of the flow model, and not a recharge zone, as suggested by the geochemical data.

Model-calculated horizontal flow rates of the present flow system in Iowa are extremely slow, ranging from a few feet per year in the recharge area in northwestern Iowa to less than $1 \mathrm{ft} / \mathrm{yr}$ in deeper parts of the aquifer (Mandle and Kontis, in press). These flow rates indicate that residence time for most of the water in the aquifer system could be tens of thousands to hundreds of thousands of years. The slow flow rates compare favorably with the carbon- 14 date of more than $35,000 \mathrm{yr}$ B.P. for water in aquifer layer 1 from a well in St. Paul, Minn. (Alexander and others, 1983).

Model-calculated horizontal flow rates under the Des Moines lobe are about 10 times larger than present flow rates. Model-calculated vertical leakage from aquifer layer 4 to aquifer layer 3 in the confined part of Iowa is less than $5,000\left(\mathrm{ft}^{3} / \mathrm{mi}^{2}\right) / \mathrm{yr}$, even under simulated glacial head from the Des Moines lobe. This amount of vertical leakage is insignificant with respect to the total amount of water in aquifer layer 5 . The volume of water per square mile in aquifer layer 3 is approximately $2 \times 10^{9} \mathrm{ft}^{3}$, assuming an average thickness of $300 \mathrm{ft}$ and a porosity of 0.25 . Only about 2.5 percent of the water in the aquifer would be replaced in $10,000 \mathrm{yr}$ at the maximum calculated flow rates owing to glacial-ice loading.

This computed result suggests that downward leakage from younger Paleozoic rocks to aquifer layer 3 probably did not cause the dilute (low dissolved solids) plume in Iowa. However, fracture permeability in younger confining units and in the carbonate rocks of the aquifer system was not specifically addressed in the model because of the paucity of field data needed to define fracture locations and patterns. Consequently, the possibility of larger amounts of vertical leakage during glaciation still exists and needs to be tested by additional isotopic data, as discussed previously.
An alternative hypothesis to explain the isotopically defined plume in Iowa is a southerly displacement of ground water having an isotopic content similar to that of modern recharge from the outcrop area in southern Minnesota. Model-calculated flow rates in aquifer layer 3 for the average ice advance in south-central Minnesota range from $10^{-6}$ to $10^{-5} \mathrm{ft} / \mathrm{s}$. At the fastest rate, meltwater would move downgradient about $60 \mathrm{mi}$ in $1,000 \mathrm{yr}$. The Des Moines lobe probably was on the outcrop area in southern Minnesota for 2,000 yr, from about 16,000 to 14,000 yr B.P. (Wright, 1972), so the model results indicate that it is possible to have had significant meltwater displacement of ground water $\left(\delta^{18} \mathrm{O}\right.$ content of about $\left.-8 \% \mathrm{oo}\right)$ toward Iowa. The meltwater that replaced the ambient ground water would be isotopically very light. This characteristic should be identifiable today in southern Minnesota, where the aquifer is confined and flow rates are low. On the contrary, $\delta^{18} \mathrm{O}$ content of water in aquifer layer 3 in south-central Minnesota is about $-9 \%$ oo; this $\delta^{18} \mathrm{O}$ content is only slightly depleted relative to modern recharge and is not characteristic of isotopically depleted water, such as is found in southern Iowa and central Illinois.

The hypothetical steady-state model of the groundwater flow system at the maximum glacial advance during Wisconsin time shows that flow rates are increased significantly only under, and immediately next to, the ice sheets. The simulated effect of the additional pressure head on the potentiometric gradient contributed by the ice sheets is dampened considerably within 30 to $50 \mathrm{mi}$ from the edge of the ice (fig. 40). The steady-state model simulations of predevelopment conditions and with glacial-ice loading during Wisconsin time suggest that the time necessary for a unit volume of recharge in northeastern Iowa and in southern Minnesota to reach north-central Missouri would have been at least tens of thousands of years. Confinement by the ice could accelerate flow rates in Iowa south of the Maquoketa Shale outcrop.

\section{HYPOTHETICAL GEOCHEMICAL MODELS}

Previous studies of the chemistry of regional aquifer systems have used mass-balance and reaction models to evalute, at least semiquantitatively, the extent of chemical mass transfer from solid to aqueous phases and the evolution of different water types-for example, Thorstenson and others (1979), Plummer (1977), Chapelle (1983), Plummer and Back (1980), and Plummer and others (1983). These models have been particularly useful for evaluating chemical changes associ- 
ated with mixing of different water types-for example, Pluinmer (1975) and Wigley and Plummer (1976).

The extent to which these approaches can be successfully used in the present study of the geochemistry of the Cambrian-Ordovician aquifer system is limited, because critical data are still unavailable on the solid phases in the aquifer, the isotopic composition of Pleistocene glacial ineltwater and precipitation, the prePleistocene topography and water table, and local values for hydraulic characteristics.

The chemical composition of major solid phases, such as calcite, in the aquifer matrices in central Iowa is unknown. Information on bulk chemistry of the rocks and petrographic information on the type and nature of cementation in the rocks are necessary to check the accuracy of inass-balance calculations of net dissolution or precipitation of carbonate minerals (Chapelle, 1983). Identification of clay minerals in the aquifer matrix also is needed to determine appropriate ionexchange selectivity coefficients for use in thermodynamic models of reaction progress. Estimates of ionexchange selectivity coefficients from water chemistry (Thorstenson and others, 1979) are not applicable because of possible multiple sources and mechanisms for observed increases in sodium concentrations in southern Iowa and northern Missouri. No direct information is available on the isotopic composition of carbon in the aquifer matrix. Such data are critical to the use of $\delta^{13} \mathrm{C}$ information to check the mass-balance inodels. Furthermore, detailed mass-transfer models that have been used to evaluate carbon isotopes in other aquifer systems (Wigley and others, 1978) cannot be applied to the Cambrian-Ordovician aquifer system because location and magnitude of past recharge were pulselike, depending on the configuration, timing, and duration of the ice sheets during the Pleistocene. Present-day concentrations of solutes may not represent steady-state conditions, and effects of hydrodynamic dispersion on the isotopic composition of ground water during recharge events cannot be excluded.

The $\delta^{18} \mathrm{O}$ and $\delta \mathrm{D}$ composition of ground water in the Cambrian-Ordovician aquifer system is probably a composite derived from numerous episodes of Pleistocene recharge to the aquifer system. Assuming that the isotopic composition of the water is conservative, based on the clustering of data around the modern meteoric water line discussed previously (fig. 35), a mixing inodel can be prepared. However, to prepare such a model, the isotopic composition of both the pre-Pleistocene ground water and the Pleistocene recharge must be known. Within the aquifer system, the isotopic gradient toward lighter water froin central to southwestern Iowa shows no reversal in trend (figs. 36,37$)$. The isotopically lightest water inay, consequently, be even more depleted in $\delta^{18} \mathrm{O}$ than $-17 \%$ oo. Estimation of the $\delta^{18} \mathrm{O}$ of Pleistocene recharge is also difficult because the $\delta^{18} \mathrm{O}$ of meltwater from glacial ice could have ranged at least from -40 to $-15 \%$ oo. The isotopic composition of precipitation in the region during the Pleistocene may have been different from what it is today.

A mixing model of a chemically conservative constituent is made using the generalized equation

$$
C_{1}\left(1-Q_{2}\right)+C_{2} Q_{2}=C_{\text {mixture }},
$$

where

$C_{1}=$ concentration in water 1 ,

$C_{2}=$ concentration in water 2 , and

$Q_{2}=$ fraction of water 2 in the mixture.

As an example of a mixing inodel, the following conditions were assumed:

1. Pre-Pleistocene ground water had an istotopic composition similar to the present-day recharge water of about $-7 \%$ oo of $\delta^{18} \mathrm{O}$.

2. Glacial meltwater entered the aquifer, resulting in a $\delta^{18} \mathrm{O}$ of $-17 \mathrm{o} / \mathrm{oo}$, the most isotopically depleted water identified.

3. Subsequent recharge southwestward caused the plume outlined by the $-10 \%$ oo line of $\delta^{18} \mathrm{O}$. This recharge water is assumed to have a $\delta^{18} \mathrm{O}$ value of $-8 \%$ oo, which is about $1 \%$ oo lighter than modern recharge.

It follows from these assumptions and for equation 14 that a 1:2.3 mixture of meltwater $\left(\delta^{18} \mathrm{O}\right.$ of $-40 \%$ and pre-Pleistocene ground water $\left(\delta^{18} \mathrm{O}\right.$ of $\left.-7 \mathrm{o} / \mathrm{oo}\right)$ would produce an observed $\delta^{18} \mathrm{O}$ of $-17 \%$ oo. This firstphase mixture subsequently would have had to be mixed with Pleistocene recharge $\left(\delta^{18} \mathrm{O}\right.$ of $\left.-8 \% / 00\right)$ at ratios of up to $1: 9$ to produce the present isotopically heavier plume in central Iowa. If the $\delta^{18} \mathrm{O}$ of the first mixture were lighter than $-17 \%$ oo, the second-phase dilution would be larger. If recharge in the second mixing phase was isotopically heavier, that is, derived from precipitation during warm interstadial periods (Emiliani, 1955; Ruddiman and McIntyre, 1976), a smaller volume of recharge would have been required. For example, if in the hypothesized second mixing phase $\delta^{18} \mathrm{O}$ of Pleistocene recharge in the plume area was about $1 \%$ oo heavier than in modern precipitation ( -6 rather than $-7 \mathrm{o} / 00$ ), the mixing ratio of ground water with $\delta^{18} \mathrm{O}$ of $-17 \%$ oo and recharge with $-6 \%$ would have been about 1:2 to produce the heavier plume. These exercises indicate that the amount of Pleistocene meltwater currently in the plume area of aquifer layer 3 could be as much as 90 percent, depending on which isotopic values were chosen in the calculations. If the 


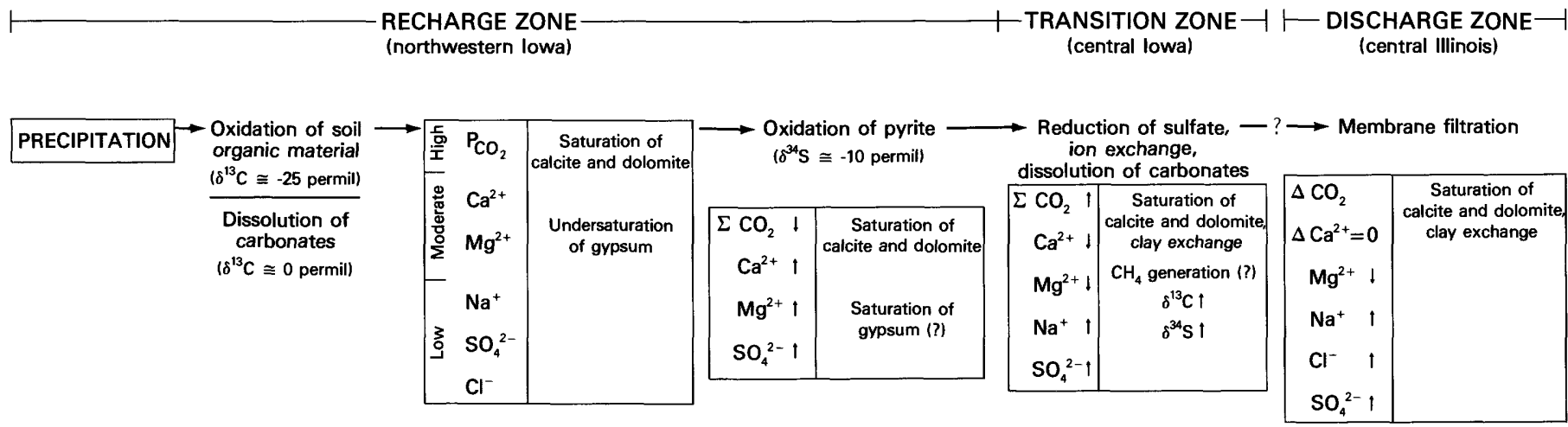

EVOLUTION OF WATER CHEMISTRY FROM NORMAL RECHARGE

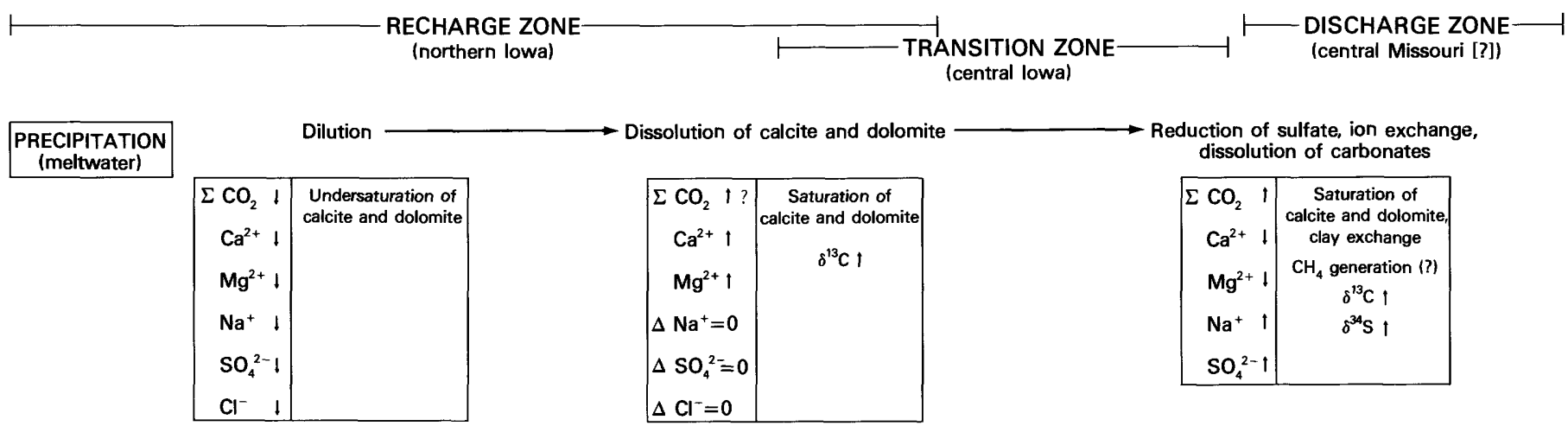

EVOLUTION OF WATER CHEMISTRY FROM MELTWATER RECHARGE

FIGURE 41.-Hypothetical geochemical models for the evolution of water chemistry in the Cambrian-Ordovician aquifer system.

$\delta^{18} \mathrm{O}$ of the pre-Pleistocene ground water was heavier than that of modern precipitation, the total percentage of Pleistocene glacial meltwater in the aquifer system would be less.

The hypothetical hydrologic and geochemical processes that may have affected the water quality of the Cambrian-Ordovician aquifer system are illustrated in figure 41. Preglacial water quality in the major recharge areas in Wisconsin, Minnesota, and northeastern Iowa may be controlled by dissolution of carbonate minerals in the aquifer matrix. Dissolution of carbonate minerals, ion exchange, and oxidation of pyrite may modify the water quality in northwestern Iowa and southwestern Minnesota. Oxidation of pyrite in the Dakota Formation and in glacial till derived from the Dakota Formation produces sulfuric acid (eq. 7) that would increase both the dissolution of carbonate minerals and the concentration of sulfate. Activities of sulfate and calcium may locally approach the solubility of gypsum, although, generally, ground water in the aquifer system and the overlying Dakota Formation and glacial drift is undersaturated with respect to gypsum and other evaporite minerals. Sulfate reduction, oxidation of organic material, and methane generation decrease concentrations of sulfate and increase inorganic carbon content. Downgradient into the transition zones of $\mathrm{Ca}$ $\mathrm{Na}-\mathrm{SO}_{4}-\mathrm{HCO}_{3}$ and $\mathrm{Na}-\mathrm{Ca}-\mathrm{SO}_{4}-\mathrm{HCO}_{3}$ facies in Iowa, additional sulfate reduction, unaccompanied by ion exchange, could cause carbonate precipitation. Membrane filtration near and in the Illinois basin may have caused precipitation of calcite, possible dolomitization of the aquifer matrix in the Illinois basin (Graf and 
others, 1966; Nesbitt, 1980; R. Shedlock, U.S. Geological Survey, written commun., 1982), and increases in sodium and chloride concentrations.

Glaciation and emplacement of Pleistocene meltwater in the aquifer system in Iowa and Missouri could cause dilution of all ground-water solutes. Although concentrations of conservative solutes, such as bromide and chloride, remained low, redissolution of carbonate minerals in the aquifer matrix increased the bicarbonate, calcium, and magnesium until equilibrium with the carbonate minerals was reestablished. This dilution and reequilibration process could have occurred many times. Glaciation also could temporarily enhance the extent of pyrite oxidation in Iowa because additional pyrite was exposed to the atmosphere by glacial erosion of the Dakota Formation.

The hypothetical model can be tested by evaluating the variations in $\delta^{13} \mathrm{C}$ in dissolved inorganic carbon. $\delta^{13} \mathrm{C}$ inorganic carbon in ground water from wells in aquifer layer 1 in southeastern Minnesota, southern Wisconsin, and northeastern Iowa ranges from about -14 to $-8 \%$ oo (fig. 42 ). $\delta^{13} \mathrm{C}$ is more than $-9 \%$ oo in aquifer layer 3 in northern Illinois and less than -17 $\%$ oo in northwestern Iowa. Of major interest is the enrichment of $\delta^{13} \mathrm{C}$ from about - 11 to more than $-8 \%$ from northeast to southwest in Iowa, approximately perpendicular to the direction of the present hydraulic gradient.

The average of $\delta^{13} \mathrm{C}$ in the major recharge areas in Minnesota and Wisconsin is close to $-12 \%$ oo in aquifer layer 1, a value that is typically obtained by the simple closed-system dissolution of carbonate minerals with $\delta^{13} \mathrm{C}$ of $0 \%$ oo (Wigley and others, 1978) by soil carbon dioxide with $\delta^{13} \mathrm{C}$ of about $-25 \%$ oo. Recharge to the aquifer system through the Dakota Formation in northwestern Iowa would obtain dissolved carbon from the oxidation of isotopically depleted organic material from both soils and lignite. The $\delta^{13} \mathrm{C}$ of the lignite is also probably about $-25 \%$ observed -17 to $-18 \%$ oo $\delta^{13} \mathrm{C}$ of inorganic carbon in the ground water in aquifer layer 3 is probably caused by fractionation processes. One likely process is bacterially mediated oxidation of methane, which would produce isotopically depleted carbon dioxide with $\delta^{13} \mathrm{C}$ of less than $-25 \%$ oo (Fenchel and Blackburn, 1979), and ultimately result in $\delta^{13} \mathrm{C}$ of dissolved inorganic carbon in the ground water of less than $-12 \%$ oo. However, sulfate reduction followed by methane production can also enrich the $\delta^{13} \mathrm{C}$ of inorganic carbon (Nissenbaum and others, 1972; Claypool and Kaplan, 1974).

The enrichment in $\delta^{13} \mathrm{C}$ in aquifer layer 3 from about $-11 \%$ in northeastern Iowa to more than $-8 \%$ oo in southwestern Iowa can be explained by successive episodes of glacial-meltwater dilution, dissolution of car- bonate minerals in the aquifer matrix, and reequilibration of ground water with respect to the carbonate system. However, it is necessary to assume that the inorganic carbon in the meltwater that recharged the aquifer system had a $\delta^{13} \mathrm{C}$ of more than $-10 \%$. The involvement of organic carbon in the dissolution of carbonate rock beneath modern glaciers is minimal, although the presence of atmospheric carbon dioxide in meltwater cannot be overlooked (Hanshaw and Hallet, 1978). The $\delta^{13} \mathrm{C}$ of modern atmospheric carbon dioxide is about $-7 \%$ oo (Hoefs, 1980). If most of the meltwater recharge occurred subglacially and if the carbon isotopic composition of Pleistocene atmospheric carbon dioxide was similar to that of today, then the observed enrichment of $\delta^{13} \mathrm{C}$ from -11 to $-8 \%$ oo of the dissolved inorganic carbon in the ground water would be conceptually consistent with the meltwater recharge model. During glacial-meltwater emplacement, $\delta^{13} \mathrm{C}$ of inorganic carbon also could be enriched by sulfate reduction followed by methane production, as discussed earlier.

Infiltration of meltwater through soils could result in soil carbon dioxide of varying isotopic composition depending on the type of vegetation (Fontes, 1980; Hoefs, 1980). Studies of plant succession after the latest Wisconsin glacial retreat in the Midwest indicate that many stages in plant succession can occur after glaciation and could range from black spruce forests to open woodlands (Wright, 1976). These vegetation types can develop even on the mantle of rock debris that covers stagnant ice. The simplest interpretation of the succession in central Minnesota, for example, is probably that the earlier colonization of herb tundra vegetation was followed by shrub and forest tundra, spruce forest, and, ultimately, pine (Birks, 1975; Gordon and Birks, 1982). These types of vegetation, as well as prairie grasses, have $\delta^{13} \mathrm{C}$ values between about -37 and $-24 \%$ oo (Hoefs, 1980). The isotopic composition of carbon dioxide derived from the oxidation of this vegetation would not be too different from that of modern soils. Repeated dissolution of carbonate minerals by meltwater with such dissolved soil carbon dioxide would result in $\delta^{13} \mathrm{C}$ of dissolved inorganic carbon of about $-12 \%$, rather than the observed enriched values of carbon-13.

\section{SUMMARY AND CONCLUSIONS}

The evolution of the water quality in the CambrianOrdovician aquifer system in the northern Midwest United States is complicated because of many possible geochemical processes and the probable effects of Pleistocene glaciation on the aquifer system. Modern 


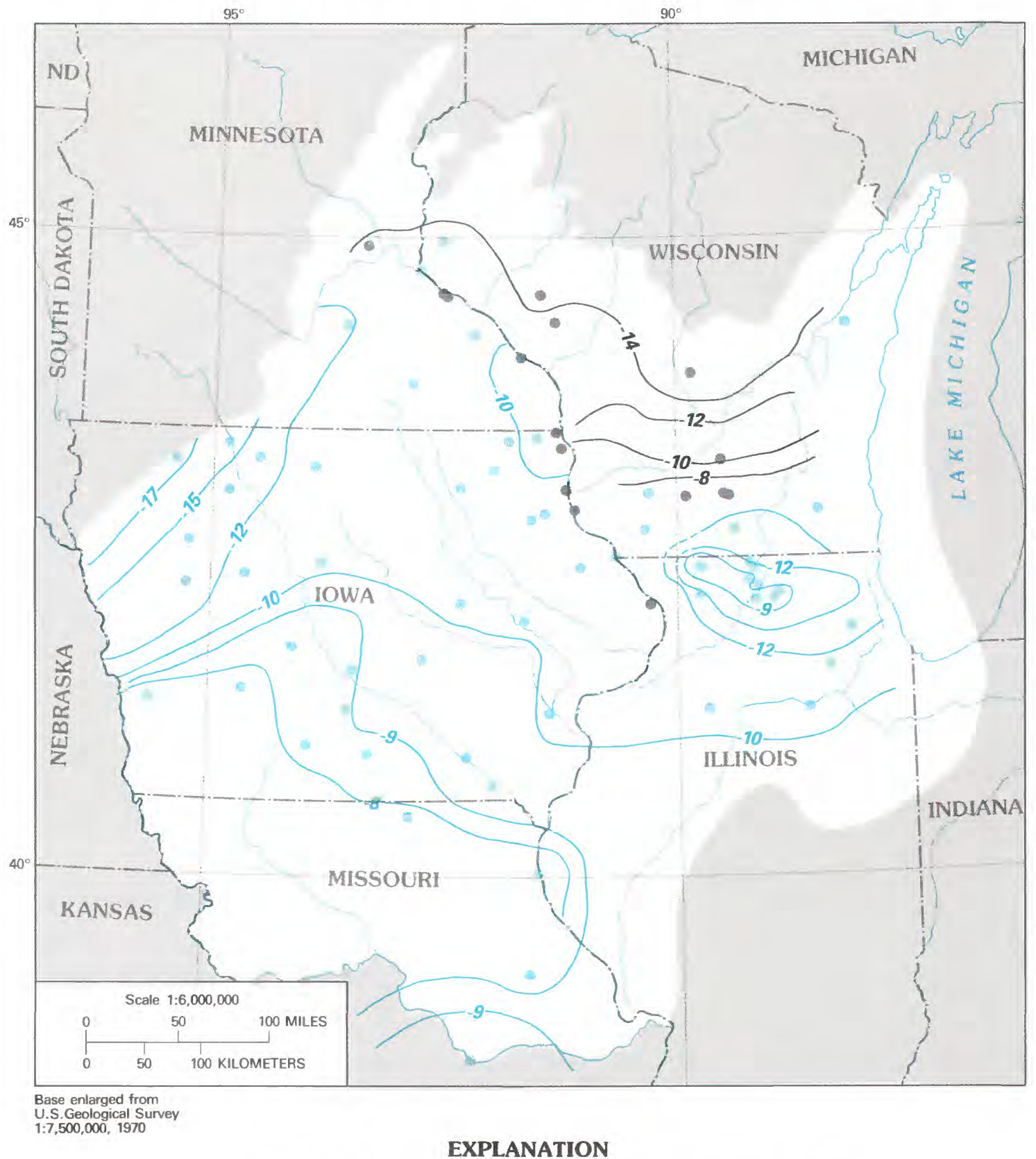

LINES OF EQUAL $\delta^{13} \mathrm{C}$ RATIO-Dashed where uncertain. Interval, permil, is variable

$$
\begin{array}{ll}
-10- & \text { Aquifer layer } 1 \\
-12-- & \text { Aquifer layer } 3
\end{array}
$$

WELL SAMPLED FOR CHEMICAL ANALYSIS DURING THIS STUDY

- Open to aquifer layer 1

Open to aquifer layer 3

FIGURE 42.-Distribution of $\delta^{13} \mathrm{C}$ ratio in aquifer layers 1 and 3. 
ground-water types may be, in part, a result of groundwater types prior to Pleistocene ice advances.

Ground water in recharge areas in Wisconsin, southern Minnesota, northeastern Iowa, and north-central Illinois is the Ca-Mg- $\mathrm{HCO}_{3}$ type and is identical in both the glacial drift and the underlying CambrianOrdovician aquifer system. Dissolved-solids concentrations are less than $500 \mathrm{mg} / \mathrm{L}$, and the major geochemical process probably is dissolution of carbonate minerals by soil carbon dioxide. In northwestern Iowa and southwestern Minnesota, however, the ground-water type in both the drift and the CambrianOrdovician aquifer system is $\mathrm{Ca}-\mathrm{Na}-\mathrm{SO}_{4}-\mathrm{HCO}_{3}$ because of the oxidation of pyrite in the Dakota Formation that overlies the aquifer system. Ground water is generally undersaturated with gypsum, and the negative $\delta^{34} \mathrm{~S}$ values in sulfate indicate that pyrite is a primary sulfur source. Dissolved-solids concentrations in places exceed $1,000 \mathrm{mg} / \mathrm{L}$.

Ground-water type changes from $\mathrm{Na}-\mathrm{Ca}-\mathrm{SO}_{4}-\mathrm{HCO}_{3}$ to $\mathrm{Na}-\mathrm{Cl}$ along the major flow path from northwestern Iowa to the Illinois basin. This is probably due to membrane filtration that would result in calcite precipitation coincident with increases in sodium and chloride.

A plume of dilute water containing less than 500 $\mathrm{mg} / \mathrm{L}$ of dissolved solids trends north to south in central Iowa under the confining Maquoketa Shale. The plume suggests that paleo-ground-water flow probably was perpendicular to the present hydraulic gradient. This interpretation also is suggested by the general trend of increasing dissolved solids perpendicular to the present hydraulic gradient in Iowa and Missouri.

Ground water in southern Iowa and northern Missouri is considerably more depleted in the heavier stable isotopes, oxygen-18 and hydrogen- 2 , than is modern recharge water. This evidence may suggest a Pleistocene, and probably a glacial-meltwater, origin of recharge. A plume of ground water isotopically heavier than ground water in southern Iowa, but isotopically lighter than modern recharge, is coincident with the plume of low-dissolved-solids water in central Iowa. It is hypothesized that the isotopic content and dilution of ground water in Iowa and Missouri probably was caused by glacial meltwater emplaced in the aquifer system when glacial ice covered the present recharge areas in northeastern Iowa and southern Minnesota. The emplaced water extends hundreds of miles from the recharge areas. This may suggest that some of the recharge occurred subglacially, under considerably steeper hydraulic gradients than those of the present.

Dilution by the emplaced water decreased the concentrations of solutes such as chloride and sulfate in central Iowa, but bicarbonate concentrations remained about the same. Reequilibration of ground water with carbonate minerals in aquifer matrices, suggested by marked enrichment of $\delta^{13} \mathrm{C}$ in dissolved inorganic carbon, could have maintained the level of bicarbonate concentrations. Dilution and re-reaction of the water with the aquifer matrix did not significantly change the ground-water types that are present down the modern hydraulic gradient. The overall chemical character of the ground water in the aquifer system in Iowa was probably established prior to glaciation and the recharge of meltwater.

Reconnaissance data on the distribution of trace solutes show that concentrations of cadmium, arsenic, and selenium seem to be related to the proximity of the Dakota Formation, which onlaps the western edge of the aquifer system in northwestern Iowa and southwestern Minnesota. Iron, manganese, cobalt, cadmium, copper, and lead concentrations are higher in proximity to the Dakota Formation in northwestern Iowa and on the edge of the Forest City basin in southwestern Iowa. Concentrations of beryllium and molybdenum are generally higher near the Forest City basin than elsewhere in the aquifer system. Silica concentrations correlate roughly with ground-water temperature in southcentral Iowa and northern Missouri; however, the solid phases controlling the solubility of silica are unknown.

Concentrations of lithium, strontium, boron, and fluoride increase from north to south in Iowa and northern Missouri in a direction perpendicular to the present hydraulic gradient. Distributions of lithium, radium226 , and bromide show a plume of lower concentration similar to the plumes of low dissolved solids and the distribution of stable isotopes of water. Uranium isotopes are at disequilibrium and show activity ratios of uranium-234 to uranium-238 as large as 100. High barium concentrations in northern Illinois and eastern Wisconsin are probably due to a zone of reducing conditions that markedly lower the sulfate concentration. Thus, barium concentrations increase until the solubility limit of barite is reached. Increased concentrations of sulfate and positive $\delta^{34} \mathrm{~S}$ values of sulfur in sulfate east of the reducing zone in eastern Wisconsin and northeastern Illinois probably indicate emplacement of sulfate derived from evaporitic gypsum. This may have occurred during Pleistocene glaciation, when the load of glacial ice could have reversed ground-water flow from east to west. Ground water from the Michigan basin could have discharged through the present recharge area in central Wisconsin and northern Illinois, where the aquifer either crops out at the land surface or subcrops beneath glacial drift.

It is possible to derive scenarios for the net dilution and dissolution process from calculations using data on the stable isotopes of the water. Such calculations are 
nonunique and are used only for the hypothetical interpretation of geochemical data because (1) the number of glacial advances in Wisconsin and Minnesota prior to Wisconsin time is uncertain, (2) the pre-Pleistocene regional ground-water flow system and topography are unknown, (3) information on the chemical and claymineral composition of the aquifer matrix in central Iowa is scant, (4) estimates of the isotopic composition of Pleistocene ice sheets have a large range, (5) different interpretations are made of the shape of the continental ice lobes, (6) no direct information is available on the leakance of younger rocks that overlie the aquifer south of the Maquoketa Shale outcrop, and (7) the extent of isotopic depletion in ground water south of the study area is unknown.

\section{SELECTED REFERENCES}

Alexander, E.C., Jr., Siegel, D.I., and Milski, J.A., 1983, Isotopic studies of the Mt. Simon aquifer, southern Minnesota [abs.]: American Geophysical Union Transactions, EOS, v. 64, no. 18, p. 225 .

American Public Health Association, 1980, Standard methods for the examination of water and wastewater: Washington, D.C., American Public Health Association, $874 \mathrm{p}$.

Andrews, J.T., 1982, On the reconstruction of Pleistocene ice sheets: A review: Quaternary Reviews, v. 1, p. 1-30.

Back, William, 1966, Hydrochemical facies and ground-water flow patterns in northern part of Atlantic Coastal Plain: U.S. Geological Survey Professional Paper 498-A, p. A1-A42.

Back, William, and Hanshaw, B.B., 1965, Chemical geohydrology, in Advances in hydroscience: New York, Academic Press, v. 2, p. 49-109.

Barnes, Ivan, 1964, Field measurement of alkalinity and pH: U.S. Geological Survey Water-Supply Paper 1535-H, 17 p.

Becker, L.E., Hreha, A.J., and Dawson, T.A., 1978, Pre-Knox (Cambrian) stratigraphy in Indiana: Indiana Geological Survey Bulletin $57,72 \mathrm{p}$.

Bennett, G.D., 1979, Regional ground-water systems analyses: Water Spectrum, v. 11 , no. 4 , p. $36-42$.

Birks, H.J.B., 1975, Late-Wisconsin vegetational history at Wolf Creek, central Minnesota: Unpub. ms. cited in Wright, H.E., Jr. (1976).

Black, R.F., 1970, Blue Mounds and the erosional history of southwestern Wisconsin, in Pleistocene geology of southern Wisconsin, Guidebook, Geological Society of America Annual Meeting, 83d, Milwaukee, 1970: Wisconsin Geological and Natural History Survey Information Circular 15, p. H1-H11.

1976, Quaternary geology of Wisconsin and contiguous upper Michigan, in Mahaney, W.C., ed., Quaternary stratigraphy of North America: Stroudsburg, Pa., Dowden, Hutchinson, and Ross, p. 93-117.

Boellstorff, John, 1976, The succession of late Cenozoic volcanic ashes in the Great Plains: A progress report, in Bayne, C.K., ed., Midwestern Friends of the Pleistocene Annual Meeting, 24th, April 1976, Guidebook: Kansas Geological Survey Guidebook Series 1, p. 37-72.

1980, North American pre-Wisconsin Pleistocene stages in transition [abs.]: Geological Society of America, North-Central Section, Annual Meeting, 14th, Bloomington, Ind., 1980, Abstracts with Programs, v. 12, no. 5, p. 220.
Bond, D.C., 1972, Hydrodynamics in deep aquifers of the Illinois basin: Illinois State Geological Survey Circular 470, $72 \mathrm{p}$.

Brown, C.N., and Morris, R.L., 1959, Naturally occurring radioelements in the ground waters of Iowa: Iowa Academy of Science Proceedings, v. 66, p. 270-271.

Burkart, M.R., 1984, Availability and quality of water from the Dakota aquifer, northwest Iowa: U.S. Geological Survey WaterSupply Paper 2215, 65 p.

Buschbach, T.C., 1964, Cambrian and Ordovician strata of northeastern Illinois: Illinois State Geological Survey Report of Investigations $218,90 \mathrm{p}$.

Chapelle, F.H., 1983, Groundwater geochemistry and calcite cementation of the Aquia aquifer in southern Maryland: Water Resources Research, v. 19, no. 2, p. 545-558.

Chapelle, F.H., and Knobel, L.L., 1983, Aqueous geochemistry and the exchangeable cation composition of glauconite in the Aquia aquifer, Maryland: Ground Water, v. 21, no. 3, p. 343-352.

Chebotarev, I.I., 1955, Metamorphism of natural waters in the crust of weathering: Geochimica et Cosmochimica Acta, v. 8, p. 22-48.

Clark, J.A., 1980, The reconstruction of the Laurentide Ice Sheet of North America from sea level data: Method and preliminary results: Journal of Geophysical Research, v. 85, p. 4307-4323.

Claypool, G.E., Holser, W.T., Kaplan, I.R., Sakai, H., and Zak, I., 1980 , The age curves of sulfur and oxygen isotopes in marine sulfate and their mutual interpretation: Chemical Geology, v. 28, p. $199-260$.

Claypool, G.E., and Kaplan, I.R., 1974, The origin and distribution of methane in marine sediments, in Kaplan, I.R., ed., Natural gases in marine sediments: New York, Plenum Publishing Co., p. 99-139.

Clayton, Lee, and Moran, S.R., 1974, A glacial process-form model, in Coates, D.R., ed., Glacial geomorphology: Binghamton, State University of New York, p. 89-119.

Clayton, R.N., Friedman, Irving, Graf, D.L., Mayeda, T.K., Meents, W.F., and Shimp, N.F., 1966, The origin of saline formation waters, 1. Isotopic composition: Journal of Geophysical Research, v. 71, no. 16, p. 3869-3882.

Cochran, R.W., and Hahne, R.M.A., 1979, Radium-226 and radium228 in Iowa drinking water, in National Conference on Radiation Control, 10th, Harrisburg, Pa., April 30-May 4, 1978, Proceedings: U.S. Department of Health, Education, and Welfare Publication (FDA) 79-8054, p. 213-218.

Coleman, D.D., 1978, An isotopic study of the Waterville underground storage area: Consultant report to Minnesota Gas Company, March 31, 1978, 41 p.

1979, Chemical and isotopic analysis of gas samples from the Wells-Bricelyn Prospect: Consultant report to Minnesota Gas Company, October 19, 1979, $20 \mathrm{p}$

Cowart, J.B., and Osmond, J.K., 1977, Uranium isotopes in groundwater: Their use in prospecting for sandstone-type uranium deposits: Journal of Geochemical Exploration, v. 8, p. 365-380.

Craig, Harmon, 1961, Isotopic variations in meteoric waters: Science, v. 133 , p. $1702-1703$.

Dansgaard, W., 1964, Stable isotopes in precipitation: Tellus, v. 16, p. 436-468.

Dansgaard, W., and Tauber, H., 1969, Glacial oxygen-18 content and Pleistocene ocean temperatures: Science, v. 166, p. 499-502.

Denton, G.H., and Hughes, T.J., eds., 1981, The last great ice sheets: New York, John Wiley, $484 \mathrm{p}$.

Drever, J.I., 1982, The geochemistry of natural waters: Englewood Cliffs, N.J., Prentice-Hall, 388 p.

Eichenberger, B.A., and Chen, K.Y., 1982, Origin and nature of selected inorganic constituents in natural waters, in Minear, R.A., and Keith, L.H., eds., Water analysis, v. 1, Inorganic species, pt. 1: New York, Academic Press, p. 1-44. 
Emiliani, Cesare, 1955, Pleistocene temperatures: Journal of Geology, v. 63 , no. 6 , p. $538-578$.

- 1971, The amplitude of Pleistocene climatic cycles at low latitudes and the isotopic composition of glacial ice, in Turekian, K.K., ed., Late Cenozoic glacial ages: New Haven, Conn., Yale University Press, p. 183-197.

Emrich, G.H., and Lucas, H.F., Jr., 1963, Geologic occurrence of natural radium-226 in ground water in Illinois: International Association of Scientific Hydrology Bulletin, v. 8, no. 3, p. 5-19.

Feder, G.L., 1979, Geochemical survey of waters of Missouri: U.S. Geological Survey Professional Paper 954-E, 78 p.

Fenchel, T., and Blackburn, T.H., 1979, Bacteria and mineral cycling: New York, Academic Press, 225 p.

Filley, T.H., and Parizek, R.R., 1983, Dynamics of groundwater flow associated with a continental glacier [abs.]: Geological Society of America Annual Meeting, 96th, Indianapolis, Ind., 1983, Abstracts with Programs, v. 15, no. 6, p. 572.

Flint, R.F., 1972, Glacial and Quaternary geology: New York, John Wiley, $892 \mathrm{p}$.

Fontes, J.Ch., 1980, Environmental isotopes in groundwater hydrology, in Fritz, Peter, and Fontes, J.Ch., eds., Handbook of environmental isotope geochemistry, v. 1: New York, Elsevier Scientific Publishing Co., p. 75-140.

Foster, M.D., 1950, The origin of high sodium bicarbonate waters in the Atlantic and Gulf Coastal Plains: Geochimica et Cosmochimica Acta, v. 1, p. 33-48.

Frye, J.C., 1963, Problems of interpreting the bedrock surface of Illinois: Illinois State Academy of Science Transactions, v. 56, no. 1 , p. $3-11$.

Frye, J.C., Willman, H.B., and Black, R.F., 1965, Outline of glacial geology of Illinois and Wisconsin, in Wright, H.E., Jr., and Frey, D.B., eds., The Quaternary of the United States: Princeton, N.J., Princeton University Press, p. 43-61.

Gann, E.E., Harvey, E.J., Barks, J.H., and Fuller, D.L., 1973, Water resources of northwestern Missouri: U.S. Geological Survey Hydrologic Investigations Atlas HA-444, 4 sheets.

Gann, E.E., Harvey, E.J., Jeffery, H.G., and Fuller, D.L., 1971, Water resources of northeastern Missouri: U.S. Geological Survey Hydrologic Investigations Atlas HA-372, 4 sheets.

Garrels, R.M., and Christ, C.L., 1965, Solutions, minerals, and equilibria: New York, Freeman, Cooper, \& Co., 450 p.

Gibb, J.P., and O'Hearn, Michael, 1980, Illinois groundwater quality data summary: Illinois State Water Survey Contract Report 230, $60 \mathrm{p}$.

Gilkeson, R.H., Cartwright, Keros, Cowart, J.B., and Holtzman, R.B., 1983, Hydrogeologic and geochemical studies of selected natural radioisotopes and barium in groundwater in Illinois: Urbana-Champaign, University of Illinois Water Resources Center Report 83-0180, Illinois State Geological Survey Contract/ Grant Report 1983-6, 93 p.

Gilkeson, R.H., and Cowart, J.B., 1982, A preliminary report on 238-uranium series disequilibrium in groundwater of the Cambrian-Ordovician aquifer system of northeastern Illinois, in Perry, E.C., Jr., and Montgomery, C.W., eds., Isotope studies of hydrologic processes: De Kalb, Northern Illinois University Press, p. 109-118.

Gilkeson, R.H., Perry, E.C., Jr., and Cartwright, Keros, 1981, Isotopic and geologic studies to identify the sources of sulfate in groundwater contining high barium concentrations: UrbanaChampaign, University of Illinois Water Resources Center Report 81-0165, Illinois State Geological Survey Contract/ Grant Report 1981-4, 39 p.

Gilkeson, R.H., Specht, S.A., Cartwright, Keros, Griffin, R.A., and Larson, T.E., 1978, Geologic studies to identify the source for high levels of radium and barium in Illinois ground-water sup- plies: A preliminary report: Urbana-Champaign, University of Illinois Water Resources Center Research Report 135, 23 p.

Goldhaber, M.B., and Kaplan, I.R., 1974, The sulfur cycle, in Goldberg, E.D., ed., The sea, v. 5: New York, Wiley-Interscience, p. 569-655.

Gordon, A.D., and Birks, H.J., 1972, Numerical methods in Quaternary paleoecology, I. Zonation of pollen diagrams: New Phytologist, v. 71 , p. 961-974.

Graf, D.L., 1982, Chemical osmosis, reverse chemical osmosis, and the origin of subsurface brines: Geochimica et Cosmochimica Acta, v. 46, p. 1431-1448.

Graf, D.L., Friedman, Irving, and Meents, W.F., 1965, The origin of saline formation waters, II: Isotopic fractionation by shale micropore systems: Illinois State Geological Survey Circular $393,32 \mathrm{p}$.

Graf, D.L., Meents, W.F., Friedman, Irving, and Shimp, N.F., 1966, The origin of saline formation waters, III: Calcium chloride waters: Illinois State Geological Survey Circular 397, 60 p.

Guswa, J.H., Siegel, D.I., and Gillies, D.C., 1982, Preliminary evaluation of the ground-water-flow system in the Twin Cities metropolitan area, Minnesota: U.S. Geological Survey WaterResources Investigations Report 82-44, $65 \mathrm{p}$.

Hahn, N.A., Jr., 1984, Radium in Wisconsin groundwater and removal methods for community water systems: Wisconsin Department of Natural Resources, $125 \mathrm{p}$.

Hall, C.W., Meinzer, O.F., and Fuller, M.L., 1911, Geology and underground waters of southern Minnesota: U.S. Geological Survey Water-Supply Paper 256, 406 p.

Hanshaw, B.B., and Coplen, T.B., 1973, Ultrafiltration by a compacted clay membrane: II: Sodium exclusion at various ionic strengths: Geochimica et Cosmochimica Acta, v. 37, p. 2311-2327.

Hanshaw, B.B., and Hallet, B., 1978, Oxygen isotope composition of subglacially precipitated calcite: Possible paleoclimatic implications: Science, v. 200, p. 1267-1270.

Hanshaw, B.B., Pearson, F.J., and Winograd, I.J., 1978, Deuterium and oxygen-18 content of Holocene through late Wisconsin precipitation [abs.]: Geological Society of America Annual Meeting, 91st, Toronto, 1978, Abstracts with Programs, v. 10, no. 7, p. 415.

Helgeson, H.C., 1969, Thermodynamics of hydrothermal systems at elevated temperatures and pressures: American Journal of Science, v. 267, p. 729-804.

Hem, J.D., 1985, Study and interpretation of the chemical characteristics of natural water (3d ed.): U.S. Geological Survey WaterSupply Paper 2254, $264 \mathrm{p}$.

Hitchon, Brian, and Krouse, H.R., 1972, Hydrogeochemistry of the surface waters of the MacKenzie River drainage basin, Canada, III: Stable isotopes of oxygen, carbon, and sulfur: Geochimica et Cosmochimica Acta, v. 36, p. 1337-1357.

Hoefs, J., 1980, Stable isotope geochemistry: New York, SpringerVerlag, $208 \mathrm{p}$.

Holser, W.T., and Kaplan, I.R., 1966, Isotope geochemistry of sedimentary sulfates: Chemical Geology, v. 1, p. 93-135.

Holt, C.L.R., Jr., and Skinner, E.L., 1973, Ground-water quality in Wisconsin through 1972: Wisconsin Geological and Natural History Survey Information Circular 22, $148 \mathrm{p}$.

Hooke, R.LeB., 1977, Basal temperatures in polar ice sheets: A qualitative review: Quaternary Research, v. 7, p. 1-13.

Horick, P.J., and Steinhilber, W.L., 1973, Mississippian aquifer of Iowa: Iowa Geological Survey Miscellaneous Map Series 3, 3 sheets.

1978, Jordan aquifer of Iowa: Iowa Geological Survey Miscellaneous Map Series 6, 3 sheets. 
Hostetler, P.B., and Garrels, R.M., 1962, Transportation and precipitation of uranium and vanadium at low temperatures, with special reference to sandstone-type uranium deposits: Economic Geology, v. 57, p. 137-167.

Hotchkiss, W.O., and Bean, E.F., 1925, A brief outline of the geology, geography, and industries of Wisconsin: Wisconsin Geological and Natural History Survey Bulletin 67, 60 p.

Howe, W.B., and others, 1961, The stratigraphic succession in Missouri: Missouri Division of Geological Survey and Water Resources, $2 d$ ser., v. 40,185 p.

Judson, Sheldon, and Osmond, J.K., 1955, Radioactivity in ground and surface water: American Journal of Science, v. 253, p. 104-116.

Kammerer, P.A., Jr., 1981, Ground-water quality atlas of Wisconsin: Wisconsin Geological and Natural History Survey Information Circular 39, $39 \mathrm{p}$.

Kaplan, I.R., and Rittenburg, S.C., 1964, Microbiological fractionation of sulfur isotopes: Journal of General Microbiology, v. 34, p. 195-212.

King, P.B., 1959, The evolution of North America: Princeton, N.J., Princeton University Press, $189 \mathrm{p}$.

Kontis, A.L., and Mandle, R.J., 1980, Data-base system for Northern Midwest Regional Aquifer-System Analysis: U.S. Geological Survey Water-Resources Investigations Report 80-104, 23 p.

Krause, D.P., 1959, Radium-228 (Mesothorium I) in Illinois well waters, in Radiological Physics Division semiannual report: Argonne National Laboratory Report ANL-6049, p. 52-54.

1960, Radium-228 (Mesothorium I) in Midwest well waters, in Radiological Physics Division semiannual report, January-June 1960: Argonne National Laboratory Report ANL-6199, p. 85-87.

Kristoff, L.M., Lordi, D.T., and Lue-Hing, Cecil, 1975, Radioactivity levels in well water supplies within the jurisdiction of the Metropolitan Sanitary District of Greater Chicago: Metropolitan Sanitary District of Greater Chicago Report 75-17, 28 p.

Kronfeld, Joel, Gradztan, E., Muller, H.W., Radin, J., Yaniv, A., and Zach, R., 1975, Excess U-234: An aging effect in confined water: Earth and Planetary Sciences Letters, v. 27, p. 342-354.

Krothe, N.C., and Bergeron, M.P., 1981, Hydrogeochemical facies in a Tertiary basin in the Milligan Canyon area, southwest Montana: Ground Water, v. 19, no. 4, p. 392-399.

Krothe, N.C., and Parizek, R.R., 1979, An anomalous occurrence of sodium bicarbonate water in a flood plain in a carbonate terrain: Ground Water, v. 17, no. 6, p. 595-603.

Langmuir, Donald, 1978, Uranium solution-mineral equilibria at low temperatures with applications to sedimentary ore deposits: Geochimica et Cosmochimica Acta, v. 42, p. 547-569.

Larson, T.E., 1963, Mineral content of public ground-water supplies in Illinois: Illinois State Water Survey Circular 90, 28 p.

Larson, T.E., and Weatherford, R.L., 1960, Natural radioactivity in Illinois water resources: American Water Works Association Journal, v. 52, no. 6, p. 769-778.

Lively, R.S., and Morey, G.B., 1982, Hydrogeochemical distribution of uranium and radon in east-central Minnesota, in Perry, E.G., Jr., and Montgomery, C.W., eds., Isotope studies of hydrologic processes: De Kalb, Northern Illinois University Press, p. 91-108.

Lucas, H.F., Jr., 1960, Study of radium-226 content of Midwest water supplies, in Radiological Physics Division semiannual report, January-June 1960: Argonne National Laboratory Report ANL-6199, p. 82-84.

1985, ${ }^{226} \mathrm{Ra}$ and ${ }^{228} \mathrm{Ra}$ in water supplies: American Water Works Association Journal, v. 77, no. 9, p. 57-67.
Lucas, H.F., Jr., and Ilcewicz, F.H., 1958, Natural radium 226 content of Illinois water supplies: American Water Works Association Journal, v. 50, no. 11, p. 1523-1532.

Maderak, M.L., 1965, Chemical quality of ground water in the Minneapolis-St. Paul area: Minnesota Department of Natural Resources, Division of Waters Bulletin 23, $44 \mathrm{p}$.

Mandle, R.J., and Kontis, A.L., in press, Simulation of regional ground-water flow in the Cambrian-Ordovician aquifer system in the northern Midwest, United States: U.S. Geological Survey Professional Paper 1405-C.

Meents, W.F., Bell, A.H., Rees, O.W., and Tilbury, W.G., 1952, Illinois oil-field brines, their geologic occurrence and chemical composition: Illinois State Geological Survey, Illinois Petroleum no. $66,38 \mathrm{p}$.

Mickelson, D.M., Knox, J.C., and Clayton, Lee, 1982, Glaciation of the Driftless Area: An evaluation of the evidence, in Quaternary history of the Driftless Area, Midwest Friends of the Pleistocene Annual Meeting, 29th, Prairie du Chien, Wis., 1982, Guidebook: Wisconsin Geological and Natural History Survey Field Trip Guidebook 5, p. 155-168.

Moran, S.R., Clayton, Lee, Hooke, R.L., Fenton, M.M., and Andriashek, L.D., 1980, Glacier-bed landforms of the prairie region of North America: Journal of Glaciology, v. 25, p. 457-476.

Morris, R.L., and Klinsky, J.W., 1962, Radiochemistry and removal characteristics of radium isotopes in Iowa well waters: Iowa Academy of Science Proceedings, v. 69, p. 396-399.

Mossler, J.H., and Hayes, J.B., 1966, Ordovician bentonites of Iowa: Journal of Sedimentary Petrology, v. 36, p. 414-427.

Munter, J.A., Ludvigson, G.A., and Bunker, B.J., 1983, Hydrogeology and stratigraphy of the Dakota Formation in northwest Iowa: Iowa Geological Survey Water-Supply Bulletin 13, 55 p.

Nesbitt, H.W., 1980, Characterization of mineral-formation water interactions in carboniferous sandstones and shales in the Illinois basin: American Journal of Science, v. 280, p. 607-630.

Nichols, M.S., and McNall, D.R., 1957, Strontium content of Wisconsin municipal waters: American Water Works Association Journal, v. 49 , p. $1493-1498$.

Nissenbaum, Arie, Presley, B.J., and Kaplan, I.R., 1972, Early diagenesis in a reducing fiord, Saanich Inlet, British Columbia, I: Chemical and isotopic changes in major components of interstitial water: Geochimica et Cosmochimica Acta, v. 36, p. 1007-1027.

Norvitch, R.F., Ross, T.G., and Brietkrietz, Alex, 1973, Water resources outlook for the Minneapolis-St. Paul metropolitan area, Minnesota: Metropolitan Council of the Twin Cities Area, $219 \mathrm{p}$.

Ostrom, M.E., 1965, Cambro-Ordovician stratigraphy of southwest Wisconsin: Wisconsin Geological and Natural History Survey Information Circular 6, $57 \mathrm{p}$.

1966, Cambrian stratigraphy in western Wisconsin: Wisconsin Geological and Natural History Survey Information Circular 7, $79 \mathrm{p}$.

Parham, W.E., and Austin, G.S., 1967, Clay mineralogy of the Glenwood Formation, southeastern Minnesota and adjacent areas: Journal of Sedimentary Petrology, v. 37, p. 863-868. 1969, Clay mineralogy, fabric and industrial uses of the Decorah Formation, southeastern Minnesota: Minnesota Geological Survey Report of Investigations 10, $32 \mathrm{p}$.

Pearson, F.J., Jr., and Rightmire, C.T., 1980, Sulphur and oxygen isotopes in aqueous sulphur compounds, in Fritz, Peter, and Fontes, J.Ch., eds., Handbook of environmental isotope geochemistry, v. 1: New York, EIsevier Scientific Publishing Co., p. 227-258. 
Perry, E.G., Jr., Gilkeson, R.J., and Grundle, T.J., 1982, H, O, and S isotopic study of the groundwater in the Cambrian-Ordovician aquifer system of northern Illinois, in Perry, E.G., Jr., and Montgomery, C.W., eds., Isotope studies of hydrologic processes: De Kalb, Northern Illinois University Press, p. 35-45.

Piper, A.M., 1944, A graphic procedure in the geochemical interpretation of water analyses: American Geophysical Union Transactions, EOS, v. 25, p. 914-923.

Plummer, L.N., 1975, Mixing of sea water with calcium carbonate ground water: Geological Society of America Memoir 142, p. 219-235.

1977, Defming reactions and mass transfer in part of the Floridan aquifer: Water Resources Research, v. 13, no. 5, p. 801-812.

Plummer, L.N., and Back, William, 1980, The mass balance approach: Application to interpreting the chemical evolution of hydrologic systems: American Journal of Science, v. 280, p. 130-142.

Plummer, L.N., Jones, B.F., and Truesdell, A.H., 1976, WATEQF-A Fortran IV version of WATEQ, a computer program for calculating chemical equilibrium of natural waters: U.S. Geological Survey Water-Resources Investigations Report 76-13, $61 \mathrm{p}$.

Plummer, L.N., Parkhurst, D.L., and Thorstenson, D.C., 1983, Development of reaction models for ground-water systems: Geochimica et Cosmochimica Acta, v. 47, p. 665-686.

Prokopovich, Nikola, and Schwartz, G.M., 1956, Minnesota limestone suitable for portland cement: Minnesota Geological Survey Summary Report 8, 39 p.

Richmond, G.M., and Fullerton, D.S., 1986, Introduction to Quaternary glaciations in the United States of America, in Sibrava, V., and others, eds., Quaternary glaciations in the Northern Hemisphere-Report of the International Geological Correlation Programme Project 24: New York, Pergamon Press, p. 3-10.

Ruddiman, W.F., and McIntyre, A., 1976, Northeast Atlantic paleoclimatic changes over the past 600,000 years: Geological Society of America Memoir 145, p. 11-146.

Ryling, R.W., 1961, A preliminary study of the distribution of saline water in the bedrock aquifers of eastern Wisconsin: Wisconsin Geological and Natural History Survey Information Circular 5, $23 \mathrm{p}$.

SAS Institute, Inc., 1979, SAS user's guide: Cary, N.C., SAS Institute, Inc., $494 \mathrm{p}$.

Sasman, R.T., Benson, G.R., Ludwigs, R.S., and Williams, T.L., 1982, Water-level trends, pumpage, and chemical quality in the Cambrian-Ordovician aquifer in Illinois, 1971-1980: Illinois State Water Survey Circular 154, $64 \mathrm{p}$.

Schicht, R.J., Adams, J.R., and Stall, J.B., 1976, Water resources availability, quality, and cost in northeastern Illinois: Illinois State Water Survey Report of Investigations 83, 90 p.

Scott, R.C., and Barker, F.B., 1961, Ground-water sources containing high concentrations of radium, in Geological Survey research 1961: U.S. Geological Survey Professional Paper 424-D, p. D357-D359.

Siegel, D.I., and Mandle, R.J., 1983, Geochemical evidence for glaciation of the Driftless Area, southwestern Wisconsin [abs.]: Geological Society of America Annual Meeting, 96th, Indianapolis, Ind., 1983, Abstracts with Programs, v. 15, no. 6, p. 687.

1984 , Isotopic evidence for glacial meltwater recharge to the Cambrian-Ordovician aquifer, north-central United States: Journal of Quaternary Research, v. 22, p. 328-335.

Sims, P.K., and Morey, G.B., eds., 1972, Geology of Minnesota: A centennial volume: St. Paul, Minnesota Geological Survey, 632 p.

Skougstad, M.W., Fishman, M.J., Friedman, L.C., Erdman, D.E., and Duncan, S.S., eds., 1979, Methods for determination of inorganic substances in water and fluvial sediments: U.S. Geological Survey Techniques of Water-Resources Investigations, Book 5, Chapter A1, $626 \mathrm{p}$.

Stauffer, C.R., 1950, The high magnesium dolomites and dolomitic limestones of Minnesota: Minnesota Geological Survey Summary Report 4, 29 p.

Steidtmann, Edward, 1924, Limestones and marls of Wisconsin: Wisconsin Geological and Natural History Survey Bulletin 66, $208 \mathrm{p}$.

Steinhilber, W.L., and Young, H.L., 1979, Plan of study for the Northern Midwest Regional Aquifer-System Analysis: U.S. Geological Survey Water-Resources Investigations Report 79-44, 20 p.

Stumm, Werner, and Morgan, J.J., 1981, Aquatic chemistry (2d ed.): New York, Wiley-Interscience, $780 \mathrm{p}$.

Sugden, D.E., 1977, Reconstruction of the morphology, dynamics, and thermal characteristics of the Laurentide Ice Sheet at its maximum: Arctic and Alpine Research, v. 9, p. 21-47.

Thiel, G.A., 1944, The geology and underground waters of southern Minnesota: Minnesota Geological Survey Bulletin 31, 247 p.

Thiel, G.A., and Stauffer, C.R., 1947, The high calcium limestones of Minnesota: Minnesota Geological Survey Summary Report 1, 13 p.

Thorstenson, D.C., Fisher, D.W., and Croft, M.G., 1979, The geochemistry of the Fox Hills-Basal Hell Creek aquifer in southwestern North Dakota and northwestern South Dakota: Water Resources Research, v. 15, no. 6, p. 1479-1498.

Trowbridge, A.C., 1921, The erosional history of the Driftless Area: University of Iowa Studies of Natural History, v. 9, 127 p.

Truesdell, A.H., and Jones, B.F., 1974, WATEQ, a computer program for calculating chemical equilibria of natural waters: U.S. Geological Survey Journal of Research, v. 2, no. 2, p. 233-248.

Turekian, K.K., and Wedepohl, K.H., 1961, Distribution of the elements in some major units of the Earth's crust: Geological Society of America Bulletin, v. 72, p. 175-192.

Weertman, Johannes, 1957, On the sliding of glaciers: Journal of Glaciology, v. 3, p. 33-38.

1961, Mechanism for the formation of inner moraines found near the edge of cold ice caps and ice sheets: Journal of Glaciology, v. 3, p. 965-978.

1964, The theory of glacier sliding: Journal of Glaciology, v. 5, p. $287-303$.

Wigley, T.M.L., and Plummer, L.N., 1976, Mixing of carbonate waters: Geochimica et Cosmochimica Acta, v. 40, p. 989-995.

Wigley, T.M.L., Plummer, L.N., and Pearson, F.J., Jr., 1978, Mass transfer and carbon isotope evolution in natural water systems: Geochimica et Cosmochimca Acta, v. 42, p. 1117-1139.

Willman, H.B., Atherton, Elwood, Buschbach, T.C., Collinson, Charles, Frye, J.C., Hopkins, M.E., Lineback, J.A., and Simon, J.A., 1975, Handbook of Illinois stratigraphy: Illinois State Geological Survey Bulletin 95, 261 p.

Winter, T.C., 1974, The natural quality of ground water in Minnesota: Minnesota Department of Natural Resources, Division of Waters Bulletin 26, 25 p.

Wright, H.E., Jr., 1972, Quaternary history of Minnesota, in Sims, P.K., and Morey, G.B., eds., Geology of Minnesota: A centennial volume: Minnesota Geological Survey, p. 515-547.

1973, Tunnel valleys, glacial surges, and subglacial hydrology of the Superior Lobe, Minnesota, in Black, R.F., Goldthwait, R.P., and Willman, H.B., eds., The Wisconsinan Stage: Geological Society of America Memoir 136, p. 251-276.

1976 , Ice retreat and revegetation in the western Great Lakes area, in Mahany, W.C., ed., Quaternary stratigraphy of North 
America: Stroudsburg, Pa., Dowden, Hutchinson, and Ross, p. 120-131.

Yapp, C.J., and Epstein, S., 1977, Climate implications of D/H ratios of meteoric water over North America (9500-22,000 B.P.) as inferred from ancient wood cellulose $\mathrm{C}-\mathrm{H}$ hydrogen: Earth and Planetary Sciences Letters, v. 34, p. 333-350.
Young, H.L., in press, Hydrogeology of the Cambrian-Ordovician aquifer system in the northern Midwest, United States: U.S. Geological Survey Professional Paper 1405-B.

Yurtsever, Y., 1975, Worldwide survey of stable isotopes in precipitation: Vienna, International Atomic Energy Agency, Isotope Hydrology Section report, $40 \mathrm{p}$. 


\section{CHEMICAL AND ISOTOPIC ANALYSES OF GROUND WATER SAMPLED DURING THE STUDY (TABLES 1-3)}



TABLE 1.-Chemical analyses of major constituents in water from wells sampled for this study

|Results in milligrams per liter, except as indicated. Analyses by U.S. Geological Survey, except Minnesota analyses by Minnesota Department of Health. Map number is location in figure 6. Site identification number is the well label in the U.S. Geological Survey WATSTORE data base]

\begin{tabular}{|c|c|c|c|c|c|c|c|c|c|c|c|c|}
\hline $\begin{array}{l}\text { Map } \\
\text { no. }\end{array}$ & $\begin{array}{c}\text { Site } \\
\text { identification } \\
\text { number }\end{array}$ & $\begin{array}{l}\text { Date } \\
\text { of } \\
\text { collec- } \\
\text { tion }\end{array}$ & $\begin{array}{l}\text { Field } \\
\text { pH } \\
\text { (stand- } \\
\text { ard } \\
\text { units) }\end{array}$ & $\begin{array}{c}\text { Calcium, } \\
\mathbf{C a}\end{array}$ & $\begin{array}{l}\text { Magne- } \\
\text { sium, } \\
\text { Mg }\end{array}$ & $\begin{array}{c}\text { Sodium, } \\
\mathrm{Na}\end{array}$ & $\begin{array}{c}\text { Potas- } \\
\text { sium } \\
\text { K }\end{array}$ & $\begin{array}{l}\text { Field } \\
\text { alka- } \\
\text { linity, } \\
\text { as } \mathrm{HCO}_{3}\end{array}$ & $\begin{array}{c}\text { Sulfate, } \\
\mathrm{SO}_{4}\end{array}$ & $\begin{array}{l}\text { Chlo- } \\
\text { ride, } \\
\text { Cl }\end{array}$ & $\begin{array}{c}\text { silica, } \\
\mathrm{SiO}_{2}\end{array}$ & $\begin{array}{l}\text { Dissolved } \\
\text { solids, } \\
\text { sum of } \\
\text { constit- } \\
\text { uents }\end{array}$ \\
\hline
\end{tabular}

\begin{tabular}{rl}
\hline 118 & 422418090255501 \\
130 & 422803087475303 \\
131 & 422803087475304 \\
& \\
& \\
71 & 432953091172001 \\
73 & 432206091130301 \\
102 & 430240091110001 \\
119 & 420842090165702 \\
& \\
& \\
& \\
1 & 461209093550701 \\
3 & 453038092584301 \\
4 & 452008092595001 \\
5 & 445648093395101 \\
19 & 445704093215611 \\
21 & 445153093202101 \\
30 & 443354092323201 \\
31 & 443407092315501 \\
32 & 443300092302901 \\
50 & 440324091404001 \\
51 & 440324091401501 \\
52 & 440318091388180 \\
53 & 440312091381201 \\
&
\end{tabular}

$33 \quad 443436091281401$

$34 \quad 443841090393001$

$38 \quad 442141091185601$

$39 \quad 442045090453601$

$54 \quad 435743089485701$

55440219088555701

$56 \quad 434312090353901$

$57 \quad 433921091132101$

$\begin{array}{ll}75 & 432336090460601\end{array}$

$\begin{array}{ll}76 & 432042090231701\end{array}$

$77 \quad 433144089595901$

$78 \quad 433220089282601$

79431849089311002

$80 \quad 432717088501701$

$103 \quad 425246091042101$

105431108090263101

108430055089534001

110430058089251401
Aquifer layer 1, Illinois
10-23-80 12-10-80 01-14-81

$\begin{array}{rr}7.4 & 50 \\ 7.2 & 310\end{array}$

$\begin{array}{rr}7.2 & 310 \\ --\quad 1000\end{array}$

\section{6}

39
930
1.3
440
15000 $\begin{array}{ccc}- & 5.9 & 1.3 \\ - & 1300 & 370 \\ - & 1400 & 37000\end{array}$
Aquifer layer 1, Iowa
06-24-80 06-10-80 06-09-80 05-15-81

$\begin{array}{ll}7.5 & 37 \\ 7.9 & 31 \\ 7.7 & 62 \\ 7.6 & 57\end{array}$

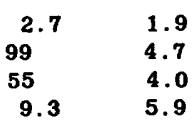

9.3

5.9
45

18
27

27
37
Aquifer layer 1, Minnesota

$\begin{array}{lrr}02-21-80 & 6.5 & 13 \\ 05-13-80 & 7.0 & 64 \\ 05-13-80 & 7.3 & 52 \\ 05-19-80 & 7.4 & 68 \\ 09-04-80 & 7.8 & 58 \\ 05-20-80 & -- & 39 \\ 02-12-80 & 6.7 & 64 \\ 02-12-80 & 6.8 & 40 \\ 02-12-80 & 7.0 & 80 \\ 02-13-80 & 7.4 & 56 \\ 02-13-80 & 7.0 & 60 \\ 02-13-80 & 6.9 & 52 \\ 02-13-80 & 7.2 & 56\end{array}$

$\begin{array}{rr}3.8 & 1.3 \\ 9.6 & 2.4 \\ 5.0 & 1.6 \\ 23 & 5.4 \\ 33 & 7.6 \\ 29 & 6.7 \\ 53 & 6.8 \\ 79 & 4.4 \\ 250 & 7.9 \\ 130 & 8.1 \\ 180 & 9.0 \\ 80 & 6.3 \\ 49 & 6.2\end{array}$

1.350

$\begin{array}{rl}50 & 5.2 \\ 340 & <5.0 \\ 241 & <5.0 \\ 368 & 30 \\ 244 & 47 \\ 239 & <5.0 \\ 276 & 34 \\ 250 & 27 \\ 262 & 36 \\ 364 & 85 \\ 362 & 180 \\ 351 & 57 \\ 312 & 37\end{array}$

245

323
52

Aquifer layer 1, Wisconsin

$08-06-80$

$08-20-80$

$08-13-80$

08-20-80

08-21-80

08-19-80

08-22-80

10-08-81

$08-28-80$

$08-28-80$

$09-05-80$

09-05-80

07-24-80

09-05-80

08-19-81

08-29-80

07-18-80

07-22-80

$\begin{array}{lc}6.8 & 13 \\ 6.7 & 34 \\ 7.2 & 16 \\ 6.4 & 2.8 \\ 7.8 & 21 \\ 8.0 & 27 \\ 7.8 & 51 \\ 7.6 & 45 \\ 7.6 & 50 \\ 7.7 & 55 \\ 7.2 & 22 \\ 7.4 & 65 \\ 7.7 & 51 \\ 7.3 & 60 \\ 7.3 & 180 \\ 7.4 & 57 \\ 7.3 & 67 \\ 7.6 & 54\end{array}$

$\begin{array}{ccr}5.9 & 2.0 & 1.7 \\ 8.9 & 7.7 & 1.0 \\ 6.7 & 3.8 & 3.6 \\ 1.2 & 1.2 & 1.4 \\ 9.0 & 1.6 & .4 \\ 34 & 15 & 1.8 \\ 27 & 1.2 & 1.0 \\ 29 & 1.9 & 1.3 \\ 28 & 1.7 & 1.0 \\ 26 & 2.7 & 1.0 \\ 11 & 3.9 & 2.5 \\ 42 & 1.8 & .6 \\ 29 & 2.5 & .9 \\ 31 & 3.7 & 1.7 \\ 40 & 140 & 12 \\ 32 & 5.2 & 1.5 \\ 37 & 6.0 & 1.0 \\ 31 & 2.9 & 1.8\end{array}$

Aquifer layer 3, Illinois

08-29-80

08-29-80

08-20-80

$08-23-80$

$08-23-80$

08-23-80

$09-03-80$

09-05-80

09-04-80

09-05-80

09-01-81

$06-21-80$

05-02-80

08-27-80

08-28-80

08-28-80

$\begin{array}{rr}7.6 & 66 \\ 7.4 & 74 \\ 7.4 & 110 \\ 7.1 & 81 \\ 7.4 & 91 \\ 7.3 & 62 \\ 6.7 & 120 \\ 7.4 & 65 \\ 7.0 & 67 \\ 7.1 & 95 \\ 7.2 & 94 \\ 8.3 & 74 \\ -- & 24 \\ 7.3 & 54 \\ 7.4 & 71 \\ 7.0 & 38\end{array}$

34
42
50
41
49
29
57
32
34
47
23
23
7.2
27
35
19

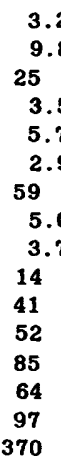

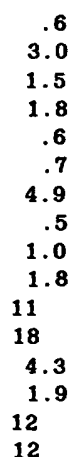

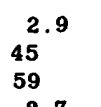

8.2

10

8.7 $\begin{array}{lr}.7 & 230 \\ .5 & 2600\end{array}$

4.456000

270

430

330

135413847088214801

$137 \quad 411933089403701$

65
99
68
16
110
256
268
294
268
232
--
378
329
--
280
305
354
329

$\begin{array}{cc}11 & 1.2 \\ 14 & 17 \\ 19 & 4.2 \\ 6.1 & 1.3 \\ 4.2 & .7 \\ 27 & 2.3 \\ 19 & 1.0 \\ 11 & 2.6 \\ 17 & .9 \\ 18 & 3.2 \\ 13 & 7.1 \\ 32 & 5.0 \\ 3.0 & .8 \\ 21 & 3.7 \\ 370 & 180 \\ 6.0 & 5.3 \\ 28 & 13 \\ 6.4 & 1.8\end{array}$

$\begin{array}{cr}16 & 84 \\ 20 & 180 \\ 17 & 110 \\ 11 & 36 \\ 8.9 & 100 \\ 21 & 260 \\ 9.8 & 240 \\ 9.9 & 250 \\ 11 & 240 \\ 12 & 230 \\ 11 & -- \\ 7.1 & 340 \\ 13 & 260 \\ 9.4 & -5 \\ 8.7 & 1100 \\ 12 & 270 \\ 6.7 & 360 \\ 9.0 & 270\end{array}$

$\begin{array}{rrccr}341 & 5.2 & .6 & 13 & 290 \\ 329 & 3.2 & 1.1 & 9.5 & 330 \\ 256 & 86 & 39 & 21 & 530 \\ 402 & 29 & 7.2 & 11 & 390 \\ 451 & 32 & 20 & 8.7 & 440 \\ 329 & 11 & .8 & 12 & 280 \\ 232 & 140 & 120 & 16 & 650 \\ 232 & 16 & 2.3 & 15 & 250 \\ 244 & 14 & 1.9 & 14 & 260 \\ 207 & 74 & 38 & 13 & 440 \\ -- & 150 & 13 & 8.0 & 510 \\ 597 & 170 & 18 & 7.0 & 660 \\ 268 & 44 & 22 & 7.1 & 330 \\ 280 & 69 & 20 & 7.5 & 390 \\ 195 & 110 & 90 & 7.8 & 520 \\ 317 & 200 & 350 & 9.3 & 1200\end{array}$




\begin{tabular}{|c|c|c|c|c|c|c|c|c|c|c|c|c|}
\hline $\begin{array}{l}\text { Map } \\
\text { no. }\end{array}$ & $\begin{array}{c}\text { Site } \\
\text { identification } \\
\text { number }\end{array}$ & $\begin{array}{l}\text { Date } \\
\text { of } \\
\text { collec- } \\
\text { tion }\end{array}$ & $\begin{array}{l}\text { Field } \\
\text { pH } \\
\text { (stand- } \\
\text { ard } \\
\text { units) }\end{array}$ & $\begin{array}{c}\text { Calcium, } \\
\text { Ca }\end{array}$ & $\begin{array}{l}\text { Magne- } \\
\text { sium, } \\
\text { Mg }\end{array}$ & $\begin{array}{c}\text { Sodium, } \\
\mathrm{Na}\end{array}$ & $\begin{array}{c}\text { Potas- } \\
\text { siun } \\
K\end{array}$ & $\begin{array}{l}\text { Field } \\
\text { alka- } \\
\text { linity, } \\
\text { as } \mathrm{HCO}_{3}\end{array}$ & $\begin{array}{c}\text { Sulfate, } \\
\mathrm{SO}_{4}\end{array}$ & $\begin{array}{l}\text { Chlo- } \\
\text { ride, } \\
\text { Cl }\end{array}$ & $\begin{array}{c}\text { Silica, } \\
\mathrm{SiO}_{2}\end{array}$ & $\begin{array}{l}\text { Dissolved } \\
\text { solids, } \\
\text { sum of } \\
\text { constit- } \\
\text { uents }\end{array}$ \\
\hline
\end{tabular}

\begin{tabular}{|c|c|}
\hline $\begin{array}{l}59 \\
61\end{array}$ & $\begin{array}{r}431620095250201 \\
432412094503301\end{array}$ \\
\hline $\begin{array}{l}62 \\
63\end{array}$ & $\begin{array}{l}431750094303001 \\
432256094183301\end{array}$ \\
\hline 64 & 431350093544201 \\
\hline 65 & 430800092540301 \\
\hline 66 & 432650092170201 \\
\hline 67 & 430337092190701 \\
\hline 68 & 431216091572001 \\
\hline 69 & 432606091470301 \\
\hline $\begin{array}{l}70 \\
72\end{array}$ & $\begin{array}{r}432800091295301 \\
431638091284102\end{array}$ \\
\hline 84 & 430210094500001 \\
\hline 88 & 423840095135001 \\
\hline 91 & 421831095152101 \\
\hline 92 & 422339094375101 \\
\hline 93 & 422136094173401 \\
\hline 94 & 422855093481501 \\
\hline 95 & 422611092552501 \\
\hline 96 & 425049092063801 \\
\hline 97 & 425708091383001 \\
\hline 98 & 424820091324001 \\
\hline 99 & 425138091234901 \\
\hline 100 & 425550091233001 \\
\hline 101 & 430330091264301 \\
\hline 116 & 423141090385801 \\
\hline 117 & 422640091002701 \\
\hline 138 & 421010092180301 \\
\hline 139 & 420200091363001 \\
\hline 140 & 420718091165401 \\
\hline 141 & 412407095391201 \\
\hline 142 & 413015094391302 \\
\hline 143 & 415021094072801 \\
\hline 144 & 413931093292001 \\
\hline 145 & 414430092433001 \\
\hline 146 & 412736093241201 \\
\hline 147 & 412025093322201 \\
\hline 148 & 410235093564901 \\
\hline 149 & 404422093445602 \\
\hline 150 & 405858093175701 \\
\hline 151 & 411332093142101 \\
\hline 152 & 412020092471001 \\
\hline 153 & 410305092490701 \\
\hline 154 & 412356092211001 \\
\hline 155 & 405750092142001 \\
\hline 156 & 410115091571801 \\
\hline 157 & 411812091412601 \\
\hline 158 & 411907091220001 \\
\hline & 404421091575801 \\
\hline
\end{tabular}

160403839091333801

6445607093364701

$7 \quad 445409093342801$

8445831093305701

9450015093280001

$10 \quad 450127093204201$

11450510093172501

12450337093130901

13450532093000301

$14 \quad 450532093000302$

15450417092570401

16450238093000401

$17 \quad 450039092594501$
Aquifer layer 3, Iowa

\begin{tabular}{|c|c|c|c|c|c|c|c|c|c|c|}
\hline $09-03-80$ & 8.0 & 340 & 130 & 190 & 10 & 505 & 1400 & 26 & 22 & 2400 \\
\hline $09-09-81$ & 7.3 & 240 & 74 & 50 & 6.0 & 841 & 570 & 2.6 & 27 & 1400 \\
\hline $09-08-81$ & 7.4 & 180 & 61 & 63 & 5.0 & 744 & 440 & 2.3 & 18 & 1100 \\
\hline $06-25-80$ & 7.3 & 110 & 35 & 58 & 3.1 & 441 & 200 & 1.9 & 18 & 650 \\
\hline $06-25-80$ & 7.3 & 78 & 27 & 19 & 4.0 & 421 & 17 & 1.1 & 14 & 370 \\
\hline $06-26-80$ & 7.8 & 66 & 26 & 16 & 6.8 & 317 & 48 & 2.0 & 7.0 & 330 \\
\hline $06-24-80$ & 7.4 & 60 & 18 & 4.2 & 1.7 & 274 & 14 & 1.3 & 11 & 250 \\
\hline $06-25-80$ & 7.5 & 52 & 21 & 6.9 & 4.3 & 263 & 27 & .9 & 6.8 & 250 \\
\hline $06-23-80$ & 7.5 & 69 & 29 & 3.5 & 1.1 & 297 & 37 & 9.4 & 11 & 320 \\
\hline $06-23-80$ & 7.2 & 93 & 24 & 5.0 & 1.6 & 386 & 10 & 9.4 & 18 & 370 \\
\hline $06-24-80$ & 7.5 & 56 & 28 & 3.5 & .8 & 366 & 3.6 & 2.1 & 12 & 300 \\
\hline $06-24-80$ & 7.3 & 86 & 21 & 3.2 & .9 & 341 & 24 & 6.5 & 14 & 330 \\
\hline $09-08-81$ & 7.6 & 240 & 78 & 100 & 7.3 & 744 & 800 & 6.6 & 26 & 1600 \\
\hline $\begin{array}{l}09-04-80 \\
09-04-80\end{array}$ & $\begin{array}{l}7.2 \\
7.5\end{array}$ & $\begin{array}{l}280 \\
190\end{array}$ & $\begin{array}{l}64 \\
48\end{array}$ & $\begin{array}{l}170 \\
150\end{array}$ & $\begin{array}{l}43 \\
32\end{array}$ & $\begin{array}{l}329 \\
282\end{array}$ & $\begin{array}{r}1100 \\
730\end{array}$ & $\begin{array}{l}30 \\
32\end{array}$ & $\begin{array}{l}8.3 \\
9.3\end{array}$ & $\begin{array}{l}1900 \\
1300\end{array}$ \\
\hline $09-02-80$ & 7.2 & 170 & 59 & 98 & 26 & 317 & 590 & 14 & 9.0 & 1100 \\
\hline $09-05-80$ & 7.5 & 120 & 44 & 92 & 25 & 372 & 390 & 20 & 9.0 & 890 \\
\hline $09-02-80$ & 7.3 & 120 & 43 & 140 & 20 & 363 & 370 & 71 & 8.4 & 960 \\
\hline $09-02-80$ & 7.4 & 78 & 32 & 74 & 21 & 329 & 180 & 11 & 8.0 & 570 \\
\hline $06-11-80$ & 7.7 & 50 & 24 & 15 & 6.6 & 293 & 39 & 1.3 & 6.6 & 290 \\
\hline $06-10-80$ & 7.3 & 82 & 27 & 6.0 & 2.6 & 347 & 47 & 13 & 10 & 370 \\
\hline $06-09-80$ & 7.6 & 65 & 27 & 4.5 & 1.6 & 293 & 43 & 8.9 & 10 & 310 \\
\hline $06-09-80$ & 7.5 & 62 & 29 & 6.7 & 5.0 & 293 & 54 & 1.7 & 7.4 & 310 \\
\hline $06-09-80$ & 7.5 & 60 & 27 & 4.6 & 2.8 & 317 & 28 & 1.9 & 11 & 290 \\
\hline $06-24-80$ & 7.5 & 87 & 39 & 7.4 & 1.2 & 366 & 75 & 14 & 13 & 420 \\
\hline $08-26-81$ & 7.6 & 52 & 33 & 2.2 & 2.2 & 329 & 16 & 2.5 & 9.5 & 280 \\
\hline $08-26-81$ & 7.8 & 50 & 24 & 62 & 11 & 329 & 90 & 21 & 8.3 & 430 \\
\hline $06-23-80$ & 7.5 & 83 & 40 & 73 & 14 & 400 & 200 & 6.8 & 7.2 & 630 \\
\hline $07-21-80$ & 7.4 & 59 & 31 & 74 & 13 & 341 & 170 & 10 & 7.8 & 540 \\
\hline $07-23-80$ & 7.5 & 62 & 30 & 68 & 13 & 341 & 160 & 14 & 7.9 & 530 \\
\hline $09-02-81$ & 7.7 & 190 & 55 & 210 & 36 & 244 & 690 & 240 & 9.7 & 1600 \\
\hline $09-02-81$ & 7.8 & 170 & 63 & 330 & 35 & 219 & 750 & 380 & 11 & 1900 \\
\hline $09-02-81$ & 7.5 & 110 & 44 & 240 & 28 & 317 & 590 & 140 & 9.7 & 1300 \\
\hline $09-01-81$ & 7.6 & 58 & 24 & 53 & 12 & 305 & 110 & 14 & 11 & 140 \\
\hline $09-01-81$ & 7.5 & 79 & 37 & 100 & 16 & 354 & 270 & 21 & 11 & 710 \\
\hline $07-30-81$ & 7.5 & 61 & 26 & 83 & 13 & 329 & 150 & 28 & 11 & 540 \\
\hline $06-10-81$ & 7.7 & 55 & 22 & 140 & 17 & 305 & 240 & 30 & 12 & 670 \\
\hline $06-10-81$ & 7.6 & 130 & 44 & 360 & 28 & 244 & 740 & 250 & 14 & 1700 \\
\hline $07-28-81$ & 7.4 & 170 & 56 & 520 & 26 & 232 & 700 & 410 & 13 & 2000 \\
\hline $06-10-81$ & 7.8 & 60 & 23 & 200 & 19 & 317 & 300 & 110 & 11 & 890 \\
\hline $06-10-81$ & 7.8 & 57 & 22 & 140 & 17 & 317 & 190 & 75 & 11 & 680 \\
\hline $08-12-81$ & 7.6 & 86 & 37 & 200 & 22 & 329 & 440 & 62 & 11 & 1000 \\
\hline $07-28-81$ & 7.5 & 65 & 26 & 190 & 17 & 317 & 320 & 130 & 4.8 & 910 \\
\hline $07-30-81$ & 7.4 & 100 & 46 & 150 & 15 & 341 & 430 & 34 & 11 & 960 \\
\hline $06-09-81$ & 8.0 & 74 & 32 & 250 & 20 & 293 & 470 & 140 & 8.7 & 1100 \\
\hline $06-09-81$ & 7.5 & 75 & 31 & 240 & 20 & 280 & 470 & 130 & 10 & 1100 \\
\hline $08-05-80$ & 7.3 & 93 & 46 & 240 & 20 & 286 & 550 & 63 & 10 & 1200 \\
\hline $10-29-80$ & 7.2 & 530 & 78 & 2500 & 70 & 295 & 2200 & 3600 & 10 & 9200 \\
\hline $06-09-81$ & 7.5 & 69 & 28 & 330 & 20 & 305 & 410 & 250 & 11 & 1300 \\
\hline $08-05-80$ & 7.6 & 62 & 28 & 490 & 17 & 312 & 400 & 370 & 9.5 & 1500 \\
\hline
\end{tabular}

Aquifer layer 3, Minnesota

$\begin{array}{rrr}05-19-80 & 7.6 & 84 \\ 05-19-80 & 7.7 & 52 \\ 05-19-80 & 7.5 & 80 \\ 05-14-80 & 7.6 & 76 \\ 05-14-80 & 7.3 & 88 \\ 05-14-80 & -- & 64 \\ 05-14-80 & 6.8 & 68 \\ 05-12-80 & 7.3 & 48 \\ 05-12-80 & 7.2 & 56 \\ 05-12-80 & -- & 40 \\ 05-12-80 & 7.0 & 56 \\ 05-14-80 & 6.8 & 56\end{array}$

$\begin{array}{lcl}44 & 25 & 3.8 \\ 29 & 4.1 & 4.0 \\ 34 & 6.4 & 2.2 \\ 34 & 3.7 & 2.2 \\ 41 & 5.3 & 2.6 \\ 24 & 5.6 & 1.8 \\ 29 & 5.4 & 1.5 \\ 17 & 4.1 & 1.8 \\ 18 & 7.9 & 3.7 \\ 16 & 3.2 & 1.2 \\ 18 & 5.4 & 1.8 \\ 19 & 7.9 & 1.7\end{array}$

$\begin{array}{cccc}26 & .9 & 20 & 470 \\ <5.0 & 2.9 & 17 & -- \\ 8.0 & 6.2 & 23 & 360 \\ 28 & 5.5 & 23 & 350 \\ 12 & .50 & 20 & 390 \\ 9.5 & 3.1 & 21 & 280 \\ 61 & 8.2 & 19 & 330 \\ 8.0 & 3.2 & 15 & 200 \\ <5.0 & 1.7 & 8.9 & - \\ <5.0 & <.5 & 15 & -- \\ 8.3 & 4.7 & 16 & 220 \\ 35 & 6.2 & 19 & 260\end{array}$


TABLE 1.-Chemical analyses of major constituents in water from wells sampled for this study-Continued

[Results in milligrams per liter, except as indicated. Analyses by U.S. Geological Survey, except Minnesota analyses by Minnesota Department of Health. Map number is location in figure 6. Site identification number is the well label in the U.S. Geological Survey WATSTORE data base]

\begin{tabular}{|c|c|c|c|c|c|c|c|c|c|c|c|c|}
\hline $\begin{array}{l}\text { Map } \\
\text { no, }\end{array}$ & $\begin{array}{c}\text { Site } \\
\text { identification } \\
\text { number }\end{array}$ & $\begin{array}{l}\text { Date } \\
\text { of } \\
\text { collec- } \\
\text { tion }\end{array}$ & $\begin{array}{l}\text { Pield } \\
\text { pH } \\
\text { (stand- } \\
\text { ard } \\
\text { units) }\end{array}$ & $\begin{array}{c}\text { Calcium, } \\
\mathrm{Ca}\end{array}$ & $\begin{array}{c}\text { Magne- } \\
\text { sium, } \\
\text { Mg }\end{array}$ & $\begin{array}{l}\text { Sodium, } \\
\mathrm{Na}\end{array}$ & $\begin{array}{c}\text { Potas- } \\
\text { sium } \\
\text { K }\end{array}$ & $\begin{array}{l}\text { Field } \\
\text { alka- } \\
\text { linity. } \\
\text { as } \mathrm{HCO}_{3}\end{array}$ & $\begin{array}{l}\text { Sulfate, } \\
\mathrm{SO}_{4}\end{array}$ & $\begin{array}{l}\text { Chlo- } \\
\text { ride, } \\
\text { C1 }\end{array}$ & $\begin{array}{c}\text { Silica, } \\
\mathrm{SiO}_{2}\end{array}$ & $\begin{array}{l}\text { Dissolved } \\
\text { solids, } \\
\text { sum of } \\
\text { constit- } \\
\text { uents }\end{array}$ \\
\hline
\end{tabular}

\begin{tabular}{|c|c|}
\hline $\begin{array}{l}20 \\
22\end{array}$ & $\begin{array}{l}445124093270801 \\
445153093202102\end{array}$ \\
\hline $\begin{array}{l}23 \\
24\end{array}$ & $\begin{array}{l}444825093125001 \\
445348093022901\end{array}$ \\
\hline 25 & 444227093125201 \\
\hline 27 & 443849093143601 \\
\hline 28 & 443806093085901 \\
\hline 35 & 442648093091301 \\
\hline 36 & 441851093341801 \\
\hline 37 & 441454092101001 \\
\hline 42 & 435542093570501 \\
\hline 43 & 434547094095802 \\
\hline 44 & 434601094010001 \\
\hline 46 & 435333092503901 \\
\hline 47 & 434221092341701 \\
\hline 48 & 434235092340201 \\
\hline 49 & 434242092160503 \\
\hline
\end{tabular}

161402842092511801 162400217091295201 $163 \quad 391622091343301$ 164383543092103001

$\begin{array}{rrr}05-20-80 & 7.6 & 68 \\ 05-20-80 & 7.6 & 76 \\ 05-22-80 & -- & 68 \\ 05-21-80 & -- & 100 \\ 05-21-80 & -- & 65 \\ 01-30-80 & 6.6 & 140 \\ 05-21-80 & 7.6 & 68 \\ 05-21-80 & -- & 76 \\ 09-03-80 & -- & 90 \\ 02-12-80 & -- & 72 \\ 02-29-80 & 7.0 & 140 \\ 01-29-80 & 7.5 & 160 \\ 02-29-80 & 7.4 & 110 \\ 09-02-80 & -- & 72 \\ 05-07-80 & -- & 60 \\ 05-07-80 & -- & 64 \\ 05-06-80 & -- & 56\end{array}$

27
32
27
36
20
36
24
29
35
27
41
44
32
20
22
22
21

$\begin{array}{rr}347 & 12 \\ 371 & 11 \\ -- & 11 \\ -- & 71 \\ 305 & 10 \\ 394 & 300 \\ 322 & 10 \\ -- & 35 \\ 378 & 33 \\ -- & 18 \\ 452 & 340 \\ 428 & 450 \\ 472 & 69 \\ 317 & 21 \\ 260 & 34 \\ 269 & 34 \\ 262 & 12\end{array}$

2.9
3.3
$<.5$
45
.5
7.8
$<.5$
.6
1.6
24
1.3
1.5
.6
1.1
.9
.8
2.6

$\begin{array}{rr}22 & 310 \\ 17 & 330 \\ 23 & -- \\ 22 & 470 \\ 14 & 260 \\ 21 & 760 \\ 15 & -- \\ 15 & 330 \\ 22 & 400 \\ 17 & 310 \\ 15 & 830 \\ 15 & 960 \\ 23 & 510 \\ 7.6 & 290 \\ 7.6 & 260 \\ 8.3 & 270 \\ 9.3 & 230\end{array}$

Aquifer layer 3, Missouri

$\begin{array}{rrr}04-07-81 & 7.4 & 110 \\ 04-07-81 & 7.3 & 210 \\ 04-06-81 & 7.5 & 72 \\ 04-06-81 & 7.4 & 51\end{array}$

$\begin{array}{rr}49 & 710 \\ 100 & 2000 \\ 36 & 280 \\ 23 & 43\end{array}$

25
46
19
5.6

$\begin{array}{rrr}319 & 1200 & 450 \\ 300 & 1200 & 3000 \\ 450 & 280 & 190 \\ 360 & 36 & 27\end{array}$

$\begin{array}{rr}8.6 & 2700 \\ 6.7 & 6700 \\ 8.5 & 1100 \\ 8.0 & 370\end{array}$

Aquifer layer 3, Wisconsin

$\begin{array}{rrr}08-04-80 & 7.8 & 36 \\ 08-14-80 & 7.5 & 13 \\ 08-08-80 & 7.3 & 300 \\ 11-10-81 & 7.7 & 61 \\ 08-26-80 & 7.1 & 120 \\ 08-27-80 & 7.6 & 63 \\ 08-27-80 & 6.8 & 12 \\ 05-12-80 & 7.5 & 94 \\ 05-29-80 & 7.5 & 56 \\ 10-21-82 & 7.6 & 53 \\ 08-26-80 & 7.6 & 66 \\ 09-04-80 & 7.5 & 57\end{array}$

$\begin{array}{ccc}20 & 2.9 & .8 \\ 5.8 & 2.5 & .8 \\ 48 & 110 & 15 \\ 35 & 4.2 & .6 \\ 57 & 17 & .7 \\ 33 & 2.3 & .8 \\ 6.1 & 3.2 & .7 \\ 49 & 21 & 1.1 \\ 28 & 4.4 & 1.8 \\ 22 & 7.0 & 1.6 \\ 37 & 3.8 & .5 \\ 30 & 20 & 3.9\end{array}$

Aquifer layer 4, Minnesota

$\begin{array}{rcccr}195 & 6.5 & 3.5 & 19 & 200 \\ 46 & 13 & 2.3 & 19 & 94 \\ 195 & 870 & 170 & 9.8 & 1600 \\ 304 & 8.0 & 8.6 & 18 & 290 \\ 439 & 47 & 41 & 26 & 640 \\ 329 & 16 & 4.5 & 13 & 310 \\ 51 & 13 & 2.8 & 22 & 89 \\ 390 & 34 & 91 & 20 & 520 \\ 305 & 2.2 & 1.3 & 9.9 & 260 \\ 266 & 19 & 1.7 & 10 & 250 \\ 341 & 19 & 3.1 & 11 & 310 \\ 280 & 31 & 41 & 15 & 340\end{array}$

$45 \quad 433615093403001 \quad 09-02-80$

$--\quad 58$

20100

Aquifer layer 4, Wisconsin

111430618087571001

11-21-80

7. 768

28

35

2.6

$--\quad 240$

15

9.8

510

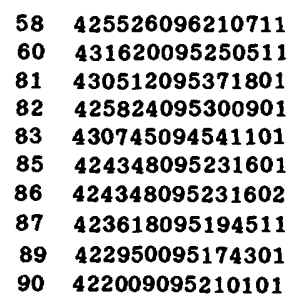

09-03-80 $09-03-80$

02-23-82

02-23-82

02-23-82

04-15-80

09-04-80

09-04-80

02-22-82

02-22-82

$\begin{array}{rr}8.0 & 250 \\ 8.0 & 300 \\ 7.4 & -- \\ 7.3 & 320 \\ 7.5 & 220 \\ 8.0 & 120 \\ 8.1 & 97 \\ 8.0 & 180 \\ 7.5 & 310 \\ 7.4 & 260\end{array}$

Aquifer layer 5, Iowa

\begin{tabular}{rr}
97 & 170 \\
110 & 150 \\
\hline 80 & \\
58 & 100 \\
38 & \\
35 & \\
42 & \\
100 & 190 \\
63 & 1
\end{tabular}

16
8.8
--
--
--
9.9
3.0
3.7
--
--

$\begin{array}{rrc}305 & 1100 & 21 \\ 442 & 1200 & 30 \\ -- & -- & -- \\ -- & 930 & 6.7 \\ -- & 520 & 5.0 \\ 355 & 260 & 18 \\ 396 & 170 & 1.6 \\ 397 & 370 & 1.1 \\ 1200 & 16 & 12\end{array}$

Aquifer layer 5, Minnesota

$2 \quad 462710092454001$ $26 \quad 443710093453501$ 41440026094355401
02-21-80

09-03-80

09-03-80

$\begin{array}{ll}-- & 60 \\ -- & 82 \\ -- & 87\end{array}$

$\begin{array}{lll}15 & 13 & 1.7 \\ 35 & 80 & 3.6 \\ 24 & 18 & 2.2\end{array}$

1.7
3.6

2.2

378
268

15
100

$\begin{array}{ccc}39 & 19 & 270 \\ 36 & 24 & 550 \\ 5.0 & 29 & 430\end{array}$


TABLE 2.-Chemical analyses of selected trace constituents in water from wells sampled for this study

[Results in micrograms per liter, except as indicated. Analyses by U.S. Geological Survey, except Minnesota analyses by Minnesota Department of Health. Map number is location in figure 6. Site identification number is the well label in the U.S. Geological Survey WATSTORE data base]

\begin{tabular}{|c|c|c|c|c|c|c|c|c|c|c|}
\hline Map & $\begin{array}{c}\text { Site } \\
\text { identification }\end{array}$ & Date & $\begin{array}{c}\text { Arsenic, } \\
\text { As }\end{array}$ & $\begin{array}{l}\text { Boron, } \\
\text { B }\end{array}$ & $\begin{array}{c}\text { Bariun, } \\
\mathrm{Ba}\end{array}$ & $\begin{array}{c}\text { Bronide, } \\
\text { Br }\end{array}$ & $\underset{\text { Cd }}{\text { Cadiniu, }}$ & $\begin{array}{c}\text { Cobalt. } \\
\text { Co }\end{array}$ & $\begin{array}{c}\text { Chro- } \\
\text { iun, } \\
\text { Cr }\end{array}$ & $\begin{array}{l}\text { Copper } \\
\text { Cu }\end{array}$ \\
\hline
\end{tabular}

$\begin{array}{lll}118 & 422418090255501 & 10-23-80 \\ 130 & 422803087475303 & 12-10-80 \\ 131 & 422803087475304 & 01-14-81\end{array}$

71432953091172001

$73 \quad 432206091130301$

$102 \quad 430240091110001$

119420842090165702
$06-24-80$

06-10-80

06-09-80

05-15-81

Aquifer layer 1, Illinols

$\begin{array}{rrr}<1 & 20 & 160 \\ <1 & 1000 & 10 \\ 2 & 11000 & 50\end{array}$
.20
.20

Aquifer layer 1, Iowa

$\begin{array}{rrrr}1 & 30 & 130 & 60 \\ 2 & 220 & 80 & < \\ 1 & 160 & 160 & <\end{array}$

$<.10$
$<.10$
$<.10$
$<.10$

Aquifer Iayer 1. Minnesota

$02-21-80$

05-13-80

05-13-80

05-19-80

09-04-80

05-20-80

02-12-80

02-12-80

02-13-80

02-13-80

02-13-80

02-13-80

$\begin{array}{rr}<1 & <50 \\ <1 & 60 \\ <1 & <50 \\ 1 & 250 \\ 1 & 210 \\ <1 & 20 \\ <1 & 210 \\ <1 & -- \\ <1 & 620 \\ <1 & 80 \\ <1 & 43 \\ <1 & 32\end{array}$

18
48
37
150
150
280
520
33
32
37
33
40

--
--
--
--
.30
--
--
--
--
--
--

$<1$
5
10

4
6
$<3$

$\begin{array}{rr}-- & <10 \\ -- & <10 \\ -- & 36\end{array}$

Aquifer layer 1, Wisconsin

08-06-80

08-20-80

08-13-80

08-20-80

$08-21-80$

08-19-80

$08-22-80$

10-08-81

$08-28-80$

08-28-80

09-05-80

09-05-80

07-24-80

09-05-80

08-19-81

08-29-80

07-18-80

07-22-80

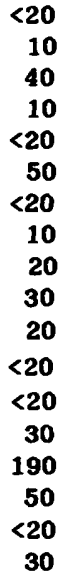

$\begin{array}{rrrrrrrr}1 & <20 & 20 & .40 & 5 & <3 & -- & 10 \\ 1 & 10 & 60 & .10 & 6 & <3 & -- & 10 \\ <1 & 40 & 20 & .70 & 5 & <3 & -- & <10 \\ 2 & 10 & 20 & <.10 & 2 & <3 & -- & <10 \\ 1 & <20 & 40 & <.10 & 2 & <3 & -- & <10 \\ 6 & 50 & 80 & .20 & 3 & <3 & -- & <10 \\ 1 & <20 & 20 & .30 & <1 & <3 & -- & <10 \\ 1 & 10 & 40 & .10 & 1 & 10 & -- & 10 \\ 1 & 20 & 50 & .30 & 3 & <3 & -- & <10 \\ 2 & 30 & 30 & .20 & 4 & <3 & -- & <10 \\ 1 & 20 & 40 & .40 & 2 & <3 & -- & <10 \\ 1 & <20 & 40 & .40 & 3 & <3 & -- & 11 \\ 4 & <20 & 30 & .20 & 3 & <3 & -- & <10 \\ 1 & 30 & 250 & .30 & 2 & <3 & -- & <10 \\ 1 & 190 & 20 & .90 & 2 & 10 & -- & 10 \\ 1 & 50 & 50 & .20 & 3 & <3 & -- & <10 \\ 1 & <20 & 60 & .90 & 3 & <3 & -- & <10 \\ 2 & 30 & 20 & .30 & <1 & <3 & -- & <10\end{array}$

2
$<1$
2
$<1$

$\begin{array}{llr}<3 & -- & <10 \\ <3 & -- & 13 \\ <3 & -- & <10 \\ <3 & -- & <10\end{array}$

10
13
$<10$

$<10$

Aquifer layer 3, Illinois

08-29-80 08-29-80 08-20-80 08-23-80 08-23-80 08-23-80 09-03-80 09-05-80 09-04-80

$\begin{array}{rrrr}1 & 20 & 20 & .20 \\ 2 & 80 & 21000 & .20 \\ 1 & 40 & 110 & .60 \\ <1 & <20 & 40 & .10 \\ <1 & -- & 40 & .10 \\ 1 & <20 & 130 & .20 \\ 1 & 270 & 80 & .60 \\ 2 & 20 & 100 & .70 \\ 1 & 50 & 110 & .30\end{array}$

$<1$
$<1$
$<1$
$<1$
8
$<1$
$<1$
2
$<1$
$<1$
$<1$
$<1$

$\begin{array}{rr}<1 & <10 \\ <1 & <10 \\ <1 & <10 \\ <1 & 11 \\ -- & <10 \\ <1 & <10 \\ <1 & <10 \\ 2 & <10 \\ <1 & 20 \\ <1 & <10 \\ <1 & <10 \\ <1 & 1\end{array}$

$\begin{array}{lll}120 & 422606089434501 & 08-29-80 \\ 121 & 421331089442201 & 08-29-80 \\ 122 & 421658089235101 & 08-20-80 \\ 123 & 422738089114601 & 08-23-80 \\ 124 & 422545089103301 & 08-23-80 \\ 125 & 421855089121601 & 08-23-80 \\ 126 & 421614089062301 & 09-03-80 \\ 127 & 420953089080501 & 09-05-80 \\ 128 & 421025088564401 & 09-04-80\end{array}$

4
3
3
$<2$
$<2$
$<2$
4
3
4

$\begin{array}{lll}<3 & - & <10 \\ <3 & -- & <10 \\ <3 & -- & <10 \\ <3 & -- & <20 \\ <3 & -- & <20 \\ <3 & -- & <20 \\ <3 & 10 & <10 \\ <3 & -- & <10 \\ <3 & -- & <10\end{array}$


TABLE 2.-Chemical analyses of selected trace constituents in water from wells sampled for this study-Continued

[Results in micrograms per liter, except as indicated. Analyses by U.S. Geological Survey, except Minnesota analyses by Minnesota Department of Health. Map number is location in figure 6. Site identification number is the well label in the U.S. Geological Survey WATSTORE data base]

\begin{tabular}{|c|c|c|c|c|c|c|c|c|c|c|c|}
\hline $\begin{array}{l}\text { Map } \\
\text { no. }\end{array}$ & $\begin{array}{l}\text { Eluo- } \\
\text { ride, } \\
F \\
(\mathrm{mg} / \mathrm{L})\end{array}$ & $\begin{array}{c}\text { Iron, } \\
\mathrm{Fe}\end{array}$ & $\begin{array}{c}\text { Lith- } \\
\text { ium, } \\
\text { Li }\end{array}$ & $\begin{array}{c}\text { Manga- } \\
\text { nese, } \\
\text { Mn }\end{array}$ & $\begin{array}{c}\text { Molyb- } \\
\text { denum, } \\
\text { Mo }\end{array}$ & $\begin{array}{c}\text { Lead, } \\
\text { Pb }\end{array}$ & $\begin{array}{l}\text { Sele- } \\
\text { niun, } \\
\text { Se }\end{array}$ & $\begin{array}{c}\text { Stron- } \\
\text { tiun, } \\
\text { Sr }\end{array}$ & $\begin{array}{c}\text { Vana- } \\
\text { diun. } \\
\text { Va }\end{array}$ & $\begin{array}{c}\text { Beryl- } \\
\text { lium. } \\
\text { Be }\end{array}$ & $\begin{array}{c}\text { Sulfide, } \\
\text { S } \\
(\mathrm{mg} / \mathrm{L})\end{array}$ \\
\hline
\end{tabular}

Aquifer layer 1, Illinois

$\begin{array}{rcrrrrrrrrr}118 & .30 & 670 & <4 & 10 & <10 & <10 & <1 & 46 & <6 & <.7 \\ 130 & 1.0 & 2700 & 180 & 190 & <10 & 17 & <1 & 13000 & <6 & <.7 \\ 131 & .30 & 8500 & 2100 & 9800 & <10 & 170 & <.1\end{array}$

Aquifer layer 1, Iowa

$\begin{array}{rrrrrrrrrrrr}71 & .20 & 220 & 7 & 9 & <10 & <10 & <1 & 100 & <6 & <.7 & -- \\ 73 & .20 & 170 & 15 & 15 & <10 & <10 & <1 & 230 & <6 & -7 & -- \\ 102 & .30 & 250 & 18 & 14 & <10 & 62 & <1 & 360 & <6 & <.7 & -- \\ 119 & .10 & 11 & 13 & 14 & <10 & <10 & <1 & 960 & <6 & <1.0 & --\end{array}$

Aquifer layer 1, Minnesota

\begin{tabular}{|c|c|c|c|c|c|c|c|c|c|c|c|}
\hline 1 & .10 & 4800 & 2 & 450 & $<1$ & $<10$ & $<1$ & -- & -- & -- & -- \\
\hline 3 & .26 & 1100 & 5 & 70 & 2 & $<10$ & $<1$ & - & - & -- & -- \\
\hline 4 & .20 & 550 & 4 & 90 & 2 & $<10$ & $<1$ & -- & - & -- & -- \\
\hline 5 & .72 & 2200 & 11 & 30 & $<1$ & $<10$ & 1 & -- & - & - & -- \\
\hline 19 & .40 & 610 & 20 & 14 & $<10$ & 34 & $<10$ & 690 & $<6$ & $<.7$ & -- \\
\hline 21 & .30 & 380 & 18 & 20 & $<1$ & $<1$ & 2 & -- & -- & -- & -- \\
\hline 30 & .18 & $<50$ & 29 & 59 & 2 & $<1$ & 3 & -- & -- & -- & -- \\
\hline 31 & .28 & 300 & 20 & 38 & $<1$ & $<10$ & -- & -- & -- & -- & -- \\
\hline 50 & .56 & 200 & 56 & 25 & $<1$ & $<1$ & $<1$ & -- & -- & -- & -- \\
\hline 51 & .04 & 580 & 63 & $<20$ & $<1$ & $<1$ & $<1$ & -- & -- & -- & -- \\
\hline 52 & 1.3 & 340 & 31 & 21 & $<1$ & $<1$ & 1 & -- & -- & - & -- \\
\hline 53 & .39 & 340 & 22 & 24 & $<1$ & 30 & 4 & -- & -- & -- & -- \\
\hline
\end{tabular}

Aquifer layer 1, Wisconsin

\begin{tabular}{|c|c|c|c|c|c|c|c|c|c|c|c|}
\hline 33 & .50 & 6 & 0 & 210 & 0 & 10 & $<1$ & 24 & $<6$ & $<.7$ & $<.1$ \\
\hline 34 & .20 & $<3$ & 5 & 5 & $<10$ & 13 & $<1$ & 58 & $<6$ & $<.7$ & $<.1$ \\
\hline 38 & .60 & 6500 & $<4$ & 190 & $<10$ & $<10$ & $<1$ & 20 & $<6$ & 2.0 & $<.1$ \\
\hline 39 & .10 & $<3$ & $<4$ & 2 & $<10$ & $<10$ & $<1$ & 12 & $<6$ & 3.0 & $<.1$ \\
\hline 54 & .20 & $<3$ & $<4$ & 260 & $<10$ & $<10$ & $<1$ & 39 & $<6$ & 3.0 & $<.1$ \\
\hline 55 & .40 & 50 & 7 & 11 & $<10$ & $<10$ & $<1$ & 1100 & $<6$ & 2.0 & $<.1$ \\
\hline 56 & .20 & 40 & $<4$ & 29 & $<10$ & 16 & $<1$ & 36 & $<6$ & 4.0 & - \\
\hline 57 & $<.10$ & 440 & 4 & 17 & 10 & 10 & $<1$ & 59 & 6 & 1.0 & -- \\
\hline 75 & .10 & 310 & $<4$ & 14 & $<10$ & 17 & $<1$ & 40 & $<6$ & $<.7$ & $<.1$ \\
\hline 76 & .10 & 150 & $<4$ & 16 & $<10$ & $<10$ & $<1$ & 45 & $<6$ & 1.0 & $<.1$ \\
\hline 77 & .10 & 10 & $<4$ & 45 & $<10$ & $<10$ & $<1$ & 41 & $<6$ & $<.7$ & .2 \\
\hline 78 & .10 & 9 & $<4$ & 5 & $<10$ & $<10$ & $<1$ & 44 & $<6$ & $<.7$ & $<.1$ \\
\hline 79 & .10 & $<3$ & $<4$ & $<1$ & $<10$ & $<10$ & $<1$ & 46 & $<6$ & $<.7$ & $<.1$ \\
\hline 80 & .30 & 840 & $<4$ & 49 & $<10$ & $<10$ & $<1$ & 1700 & $<6$ & $<.7$ & $<.1$ \\
\hline 103 & .20 & 1700 & 50 & 16 & 11 & 10 & $<1$ & 4400 & 6 & 1.0 & $<.1$ \\
\hline 105 & .20 & 750 & 5 & 26 & $<10$ & $<10$ & $<1$ & 58 & $<6$ & $<.7$ & .2 \\
\hline 108 & .10 & 8 & $<4$ & $<1$ & 10 & 13 & $<1$ & 38 & $<6$ & $<.7$ & $<.1$ \\
\hline 110 & .10 & 140 & $<4$ & 16 & $<10$ & $<10$ & $<1$ & 76 & $<6$ & .8 & .1 \\
\hline
\end{tabular}

Aquifer layer 3, Illinois

\begin{tabular}{|c|c|c|c|c|c|c|c|c|c|c|c|}
\hline 120 & .20 & 1500 & $<4$ & 28 & 13 & 18 & $<1$ & 61 & $<6$ & $<.7$ & -- \\
\hline 121 & .30 & 270 & 5 & 13 & $<10$ & 12 & $<1$ & 540 & $<6$ & $<.7$ & -- \\
\hline 122 & .20 & 100 & 5 & $<1$ & $<10$ & 14 & 1 & 110 & $<6$ & 1.0 & - \\
\hline 123 & .10 & 3 & 5 & $<1$ & $<10$ & 21 & $<1$ & 48 & $<6$ & $<.7$ & -- \\
\hline 124 & .10 & 16 & 6 & $<1$ & $<10$ & $<10$ & $<1$ & 43 & $<6$ & $<.7$ & -- \\
\hline 125 & .10 & 21 & 4 & 5 & $<10$ & $<10$ & $<1$ & 48 & $<6$ & $<.7$ & -- \\
\hline 126 & .20 & 330 & 6 & 58 & $<10$ & 11 & $<1$ & 160 & $<6$ & $<.7$ & -- \\
\hline 127 & .20 & 1700 & $<4$ & 44 & $<10$ & $<10$ & $<1$ & 120 & $<6$ & $<.7$ & -- \\
\hline 128 & .20 & $<3$ & $<4$ & $<1$ & $<10$ & $<10$ & $<1$ & 72 & $<6$ & $<.7$ & \\
\hline
\end{tabular}


TABLE 2.-Chemical analyses of selected trace constituents in water from wells sampled for this study-Continued

[Results in micrograms per liter, except as indicated. Analyses by U.S. Geological Survey, except Minnesota analyses by Minnesota Department of Health. Map number is location in figure 6. Site identification number is the well label in the U.S. Geological Survey WATSTORE data base]

\begin{tabular}{|c|c|c|c|c|c|c|c|c|c|c|}
\hline $\begin{array}{l}\text { Map } \\
\text { no. }\end{array}$ & $\begin{array}{c}\text { Site } \\
\text { identification } \\
\text { number }\end{array}$ & $\begin{array}{c}\text { Date } \\
\text { of } \\
\text { sample }\end{array}$ & $\begin{array}{c}\text { Arsenic, } \\
\text { As }\end{array}$ & $\begin{array}{c}\text { Boron, } \\
\text { B }\end{array}$ & $\begin{array}{l}\text { Bariun, } \\
\text { Ba }\end{array}$ & $\begin{array}{c}\text { Bromide, } \\
\text { Br } \\
(\mathbf{g} / \mathrm{L})\end{array}$ & $\begin{array}{c}\text { Cadaium, } \\
\text { Cd }\end{array}$ & $\begin{array}{c}\text { Cobalt, } \\
\text { Co }\end{array}$ & $\begin{array}{l}\text { Chro- } \\
\text { mium, } \\
\text { Cr }\end{array}$ & $\begin{array}{c}\text { Copper, } \\
\mathrm{Cu}\end{array}$ \\
\hline 129 & 421329088531701 & $09-05-80$ & 1 & 30 & 50 & .50 & 3 & $<3$ & -- & $<10$ \\
\hline 132 & 422803087475306 & $09-01-81$ & 1 & 290 & 2 & .10 & 1 & 3 & $-\rightarrow$ & 10 \\
\hline 133 & 415632088071201 & $06-21-80$ & 1 & 560 & 80 & .20 & 1 & $<3$ & -- & $<10$ \\
\hline 134 & 415818087565201 & $05-02-80$ & 1 & 910 & 20 & .20 & $<1$ & $<3$ & -- & 11 \\
\hline 135 & 413847088214801 & $08-27-80$ & 1 & 470 & 30 & .40 & $<1$ & $<3$ & -- & $<10$ \\
\hline 136 & 411858088363401 & $08-28-80$ & 1 & 270 & 30 & .70 & 2 & $<3$ & -- & $<10$ \\
\hline 137 & 411933089403701 & $08-28-80$ & $<1$ & 850 & 20 & 1.0 & 5 & $<3$ & -- & $<10$ \\
\hline
\end{tabular}

\begin{tabular}{|c|c|}
\hline 59 & 431620095250201 \\
\hline 61 & 432412094503301 \\
\hline 62 & 431750094303001 \\
\hline 63 & 432256094183301 \\
\hline 64 & 431350093544201 \\
\hline 65 & 430800092540301 \\
\hline 66 & 432650092170201 \\
\hline 67 & 430337092190701 \\
\hline 68 & 431216091572001 \\
\hline 69 & 432606091470301 \\
\hline 70 & 432800091295301 \\
\hline 72 & 431638091284102 \\
\hline 84 & 430210094500001 \\
\hline 88 & 423840095135001 \\
\hline & $\begin{array}{l}421831095152101 \\
422339094375101\end{array}$ \\
\hline 93 & 422136094173401 \\
\hline & 422855093481501 \\
\hline & 422611092552501 \\
\hline & \\
\hline 97 & 425708091383001 \\
\hline 98 & 42482009 \\
\hline 99 & 425138091234901 \\
\hline 100 & 425550091233001 \\
\hline 101 & 430330091264301 \\
\hline 116 & 423141090385801 \\
\hline 117 & 422640091002701 \\
\hline 138 & 421010092180301 \\
\hline 139 & 420200091363001 \\
\hline 140 & 420718091165401 \\
\hline 141 & 412407095391201 \\
\hline 142 & 413015094391302 \\
\hline 143 & 415021094072801 \\
\hline 144 & 413931093292001 \\
\hline 145 & 414430092433001 \\
\hline 146 & 412736093241201 \\
\hline 147 & 412025093322201 \\
\hline 148 & 410235093564901 \\
\hline 145 & 404422093445602 \\
\hline & $4058580931757 C$ \\
\hline [5] & 411332093142101 \\
\hline 152 & 412020092471001 \\
\hline 15 & 410305092490701 \\
\hline 15 & 412356092211001 \\
\hline 155 & 405750092142001 \\
\hline 156 & 410115091571801 \\
\hline 15 & 411812091412601 \\
\hline & 411907091220001 \\
\hline & \\
\hline
\end{tabular}

09-03-80 09-09-81 $09-08-81$ 06-25-80 $06-25-80$ 06-26-80 06-24-80 06-25-80 06-23-80 06-23-80 06-24-80 06-24-80 09-08-81 09-04-80 09-04-80 09-02-80 09-05-80 09-02-80 09-02-80 06-11-80 06-10-80 06-09-80 06-09-80 06-09-80 06-24-80 08-26-81 08-26-81 06-23-80 07-21-80 07-23-80 09-02-81 09-02-81 09-02-81 09-01-81 09-01-81 07-30-81 06-10-81 06-10-81 07-28-81 06-10-81 06-10-81 08-12-81 07-28-81 07-30-81 06-09-81 06-09-81 08-05-80 10-29-80 06-09-81 08-05-80
Aquifer layer 3, Iowa

$\begin{array}{rrrr}3 & 300 & 20 & .20 \\ 2 & 300 & 23 & .10 \\ 2 & 210 & 21 & <.10 \\ 1 & 140 & 60 & <.10 \\ 1 & 70 & 140 & <.10 \\ 1 & 250 & 60 & <.10 \\ 1 & 70 & 140 & .10 \\ <10 & 310 & 70 & <.10 \\ 1 & 60 & 140 & .10 \\ 1 & 20 & 120 & .10 \\ <10 & <20 & 60 & .10 \\ <10 & 30 & 80 & <.10 \\ 1 & 360 & 31 & <.10 \\ 1 & 2200 & 20 & .90 \\ 1 & 1100 & 30 & .50 \\ 1 & 990 & 20 & .80 \\ 1 & 1200 & 20 & .80 \\ 2 & 1100 & 20 & .90 \\ 1 & 1100 & 30 & .40 \\ <10 & 220 & 70 & <.10 \\ 4 & 50 & 110 & .10 \\ 1 & 140 & 140 & <.10 \\ 2 & 180 & 60 & <.10 \\ <10 & 130 & 100 & <.10 \\ <10 & 80 & 100 & .10 \\ 2 & <20 & 150 & <.10 \\ 1 & 460 & 40 & .10 \\ <10 & 590 & 30 & .10 \\ 1 & 610 & 30 & .30 \\ 1 & 570 & 40 & .30 \\ <10 & 820 & 17 & .90 \\ 1 & 1300 & 23 & .20 \\ 1 & 1700 & 21 & .60 \\ <10 & 600 & 48 & .10 \\ <10 & 1100 & 27 & .10 \\ 2 & 760 & 40 & .20 \\ <10 & 1200 & 170 & .20 \\ 1 & 1600 & 310 & .90 \\ 1 & 1900 & 20 & 1.5 \\ 1 & 1500 & 130 & .40 \\ 1 & 1100 & 120 & .30 \\ 1 & 1400 & 30 & .30 \\ 1 & 1400 & 30 & .40 \\ 2 & 870 & 30 & .20 \\ 1 & 1400 & 130 & .50 \\ 1 & 1300 & 100 & .50 \\ 2 & 670 & 30 & .40 \\ 1 & 5700 & 30 & 9.8 \\ 1 & 1700 & 140 & .80 \\ 3 & 1600 & 30 & .50\end{array}$

\begin{tabular}{r}
7 \\
1 \\
1 \\
$<1$ \\
$<1$ \\
3 \\
$<1$ \\
$<1$ \\
$<1$ \\
$<1$ \\
2 \\
$<1$ \\
1 \\
6 \\
4 \\
5 \\
3 \\
4 \\
4 \\
$<1$ \\
$<1$ \\
1 \\
$<1$ \\
$<1$ \\
2 \\
$<1$ \\
$<1$ \\
3 \\
$<1$ \\
2 \\
$<2$ \\
$<2$ \\
$<1$ \\
$<1$ \\
$<1$ \\
$<1$ \\
$<1$ \\
$<2$ \\
$<1$ \\
$<1$ \\
$<1$ \\
$<1$ \\
$<1$ \\
$<1$ \\
$<1$ \\
$<1$ \\
4 \\
$<$ \\
\hline 1 \\
$<$ \\
$<$ \\
$<$ \\
$<$ \\
$<$ \\
$<$ \\
$<$ \\
$<$ \\
$<$ \\
$<$ \\
$<$
\end{tabular}

$\begin{array}{lll}<3 & -- & <10 \\ <3 & -- & <10 \\ 4 & -- & <10 \\ <3 & -- & <10 \\ <3 & -- & <10 \\ <3 & -- & <10 \\ <3 & -- & <10 \\ <3 & -- & <10 \\ <3 & -- & <10 \\ <3 & -- & <10 \\ <3 & -- & <10 \\ <3 & -- & <10 \\ <3 & -- & <10 \\ <3 & -- & <10 \\ <3 & -- & <10 \\ <3 & -- & <10 \\ <3 & -- & <10 \\ <3 & <3 \\ <3 & -- & <10 \\ <3 & -- & <10 \\ <3 & -- & <10 \\ <3 & -- & <10 \\ <3 & -- & <10 \\ <3 & -- & <10 \\ <3 & -- & <10 \\ <3 & -- & <10 \\ <3 & -- & <10 \\ <3 & -- & <10 \\ <3 & -10 \\ <3 & -- & <10 \\ <3 & -- & <10 \\ <3 & -- & <10 \\ <6 & -- & <20 \\ <6 & -- & <20 \\ <3 & -- & <10 \\ <3 & -- & <10 \\ <3 & -- & <10 \\ <3 & -- & <10 \\ <3 & -- & <10 \\ <3 & <10 \\ <6 & -- & <20 \\ <3 & -- & <10 \\ <3 & -- & <10 \\ <3 & -- & <10 \\ <3 & -- & <10 \\ <3 & -- & <10 \\ <3 & -- & <10 \\ <3 & -- & <10 \\ <3 & -- & <10 \\ <3 & -- & <10 \\ 10 & -- & 24 \\ <3 & -- & <10 \\ <3 & -- & <10\end{array}$


TABLE 2.-Chemical analyses of selected trace constituents in water from wells sampled for this study-Continued

[Results in micrograms per liter, except as indicated. Analyses by U.S. Geological Survey, except Minnesota analyses by Minnesota Department of Health. Map number is location in figure 6. Site identification number is the well label in the U.S. Geological Survey WATSTORE data base]

\begin{tabular}{|c|c|c|c|c|c|c|c|c|c|c|c|}
\hline $\begin{array}{l}\text { Map } \\
\text { no. }\end{array}$ & $\begin{array}{c}\text { Fluo- } \\
\text { ride, } \\
E \\
(\mathrm{~g} / \mathrm{L})\end{array}$ & $\begin{array}{c}\text { Iron, } \\
\text { Fe }\end{array}$ & $\begin{array}{c}\text { Lith- } \\
\text { iun, } \\
\text { L1 }\end{array}$ & $\begin{array}{c}\text { Manga- } \\
\text { nese, } \\
\text { Mn }\end{array}$ & $\begin{array}{c}\text { Molyb- } \\
\text { denuw, } \\
\text { Mo }\end{array}$ & $\begin{array}{c}\text { Lead, } \\
\text { Pb }\end{array}$ & $\begin{array}{l}\text { Sele- } \\
\text { niun, } \\
\text { Se }\end{array}$ & $\begin{array}{c}\text { stron- } \\
\text { tiun, } \\
\text { sr }\end{array}$ & $\begin{array}{l}\text { Vana- } \\
\text { diua, } \\
\text { Va }\end{array}$ & $\begin{array}{c}\text { Beryl- } \\
\text { lium, } \\
\text { Be }\end{array}$ & $\begin{array}{c}\text { Sulf Ide, } \\
\text { S } \\
(n g / L)\end{array}$ \\
\hline 129 & .20 & $<3$ & $<4$ & $<1$ & $<10$ & $<10$ & $<1$ & 83 & $<6$ & $<.7$ & -- \\
\hline 132 & 1.4 & 650 & 24 & 14 & 10 & 10 & $<1$ & 8300 & 6 & 1.0 & $<.1$ \\
\hline 133 & 1.1 & 22 & 49 & 13 & $<10$ & 54 & $<1$ & 3900 & $<6$ & 2.0 & -- \\
\hline 134 & 3.5 & 200 & 73 & 11 & 12 & $<10$ & $<1$ & 710 & $<6$ & 4.0 & -- \\
\hline 135 & 1.1 & 4 & 59 & 48 & $<10$ & 21 & $<1$ & 1800 & $<6$ & $<.7$ & -- \\
\hline 136 & .70 & 9 & 67 & 10 & $<10$ & 18 & $<1$ & 1300 & $<6$ & $<.7$ & -- \\
\hline 137 & 1.5 & 580 & 220 & 9 & $<10$ & $<10$ & $<1$ & 2700 & $<6$ & $<.7$ & $\rightarrow$ \\
\hline
\end{tabular}

Aquifer layer 3, Iowa

\begin{tabular}{|c|c|c|c|c|c|c|c|c|c|c|c|}
\hline 59 & .30 & 82 & 140 & 550 & $<10$ & 26 & $<1$ & 3000 & $<6$ & $<.7$ & -- \\
\hline 61 & .30 & 1500 & 70 & 330 & 20 & $<10$ & $<1$ & 1100 & $<6$ & $<1.0$ & .8 \\
\hline 62 & .40 & 99 & 51 & 130 & $<10$ & 10 & $<1$ & 1100 & $<6$ & $<1.0$ & 1.0 \\
\hline 63 & .30 & 2600 & 30 & 36 & 25 & $<10$ & $<1$ & 350 & $<6$ & $<.7$ & -- \\
\hline 64 & .40 & 260 & 23 & 25 & 17 & $<10$ & $<1$ & 320 & $<6$ & $<.7$ & -- \\
\hline 65 & .70 & 380 & 31 & 8 & 21 & $<10$ & $<1$ & 510 & $<6$ & $<.7$ & - \\
\hline 66 & .60 & 630 & 10 & 10 & $<10$ & $<10$ & $<1$ & 150 & $<6$ & $<.7$ & -- \\
\hline 67 & .60 & 91 & 14 & 5 & $<10$ & 17 & $<1$ & 280 & $<6$ & $<.7$ & -- \\
\hline 68 & .30 & $<3$ & 7 & 2 & 17 & $<10$ & 1 & 220 & $<6$ & $<.7$ & -- \\
\hline 69 & .20 & 7 & 7 & 25 & 16 & $<10$ & $<1$ & 100 & $<6$ & $<.7$ & -- \\
\hline 70 & .10 & $<3$ & $<4$ & 2 & $<10$ & $<10$ & $<1$ & 52 & $<6$ & $<.7$ & -- \\
\hline 72 & .20 & 15 & 5 & 3 & 15 & $<10$ & $<1$ & 97 & $<6$ & $<.7$ & - \\
\hline 84 & .30 & 2500 & 72 & 170 & $<10$ & 10 & $<1$ & 1900 & $<6$ & $<1.0$ & .7 \\
\hline 88 & 1.7 & 1300 & 210 & 59 & $<10$ & 24 & $<1$ & 9100 & $<6$ & $<.7$ & -- \\
\hline 91 & 2.0 & 3700 & 170 & 57 & $<10$ & 22 & $<1$ & 6000 & $<6$ & $<.7$ & -- \\
\hline 92 & 1.5 & 2100 & 95 & 39 & $<10$ & 18 & $<1$ & 4400 & $<6$ & $<.7$ & -- \\
\hline 93 & 1.6 & 2600 & 150 & 33 & $<10$ & 14 & $<1$ & 5200 & $<6$ & $<.7$ & -- \\
\hline 94 & 1.3 & 210 & 130 & 14 & $<10$ & 13 & $<1$ & 4000 & $<6$ & $<.7$ & -- \\
\hline 95 & 1.2 & 1200 & 120 & 18 & $<10$ & 10 & $<1$ & 2200 & $<6$ & $<.7$ & -- \\
\hline 96 & .80 & 150 & 24 & 8 & $<10$ & $<10$ & $<1$ & 530 & $<6$ & $<.7$ & -- \\
\hline 97 & .40 & 6 & 5 & 4 & $<10$ & 66 & 1 & 250 & $<6$ & $<.7$ & - \\
\hline 98 & .50 & 7 & $<4$ & 37 & $<10$ & $<10$ & 2 & 150 & $<6$ & $<.7$ & -- \\
\hline 99 & .40 & 22 & 14 & 8 & 11 & 78 & $<1$ & 370 & $<6$ & $<.7$ & -- \\
\hline 100 & .50 & 260 & 9 & 9 & $<10$ & 87 & $<1$ & 270 & $<6$ & 2.0 & - \\
\hline 101 & .30 & 210 & 9 & 9 & 16 & $<10$ & $<1$ & 120 & $<6$ & $<.7$ & -- \\
\hline 116 & .20 & 170 & 7 & 10 & $<10$ & $<10$ & $<1$ & 92 & $<6$ & $<1.0$ & $<.1$ \\
\hline 117 & .90 & 280 & 77 & 8 & $<10$ & $<10$ & $<1$ & 1100 & $<6$ & $<1.0$ & .1 \\
\hline 138 & 1.1 & 1400 & 110 & 19 & $<10$ & $<10$ & $<1$ & 1900 & $<6$ & $<.7$ & -- \\
\hline 139 & 1.3 & 170 & 90 & 3 & $<10$ & $<10$ & $<1$ & 1500 & $<6$ & $<.7$ & -- \\
\hline 140 & 1.2 & 120 & 79 & 4 & $<10$ & $<10$ & $<1$ & 1600 & $<6$ & $<.7$ & - \\
\hline 141 & 2.9 & 2500 & 240 & 120 & $<20$ & $<20$ & $<1$ & 6300 & $<12$ & $<2.0$ & 1.0 \\
\hline 142 & 2.7 & 370 & 280 & 17 & $<20$ & $<20$ & $<1$ & 5800 & $<12$ & $<2.0$ & .5 \\
\hline 143 & 2.3 & 440 & 270 & 8 & $<10$ & $<10$ & $<1$ & 4700 & $<6$ & $<1.0$ & .5 \\
\hline 144 & 1.7 & 120 & 63 & 4 & $<10$ & $<10$ & $<1$ & 1300 & $<6$ & $<1.0$ & .5 \\
\hline 145 & 1.4 & 320 & 140 & 5 & $<10$ & $<10$ & $<1$ & 2300 & $<6$ & $<1.0$ & .8 \\
\hline 146 & 1.7 & 2000 & 86 & 18 & $<10$ & $<10$ & $<1$ & 1700 & $<6$ & $<1.0$ & - \\
\hline 147 & 2.7 & 210 & 150 & 3 & $<10$ & $<10$ & $<1$ & 2100 & $<6$ & $<1.0$ & .1 \\
\hline 148 & 2.7 & 1300 & 350 & 18 & $<20$ & $<20$ & $<1$ & 5700 & $<6$ & $<2.0$ & . 1 \\
\hline 149 & 2.8 & 720 & 420 & 10 & $<10$ & $<10$ & $<1$ & 6000 & $<6$ & $<1.0$ & $<.1$ \\
\hline 150 & 2.7 & 840 & 200 & 8 & $<10$ & $<10$ & $<1$ & 2400 & $<6$ & $<1.0$ & .9 \\
\hline 151 & 2.2 & 800 & 130 & 12 & $<10$ & $<10$ & $<1$ & 1800 & $<6$ & $<1.0$ & $<.1$ \\
\hline 152 & 1.2 & 2300 & 210 & 32 & $<10$ & $<10$ & $<1$ & 2500 & $<6$ & $<1,0$ & .2 \\
\hline 153 & 1.6 & 51 & 4 & $<1$ & $<10$ & $<10$ & $<1$ & 44 & $<6$ & $<1.0$ & $<.1$ \\
\hline 154 & 1.3 & 2200 & 170 & 18 & $<10$ & $<10$ & $<1$ & 2300 & $<6$ & $<1.0$ & - \\
\hline 155 & 1.7 & 2100 & 260 & 91 & $<10$ & $<10$ & $<1$ & 2700 & $<6$ & $<1.0$ & $<.1$ \\
\hline 156 & 1.6 & 530 & 240 & 8 & $<10$ & $<10$ & $<1$ & 2500 & $<6$ & $<1.0$ & $<.1$ \\
\hline 157 & 1.3 & 290 & 220 & 4 & $<10$ & 16 & $<1$ & 2500 & $<6$ & $<.7$ & -- \\
\hline 158 & 1.5 & 10000 & 620 & 130 & $<10$ & 17 & $<1$ & 19000 & 5 & $<1.0$ & -- \\
\hline 159 & 2.3 & 1200 & 290 & 12 & $<10$ & $<10$ & $<1$ & 2500 & $<6$ & $<1.0$ & $<.1$ \\
\hline 160 & 4.1 & 770 & 360 & 8 & $<10$ & $<10$ & $<1$ & 2600 & $<6$ & 1.0 & -- \\
\hline
\end{tabular}


TABLE 2.-Chemical analyses of selected trace constituents in water from wells sampled for this study-Continued

[Results in micrograms per liter, except as indicated. Analyses by U.S. Geological Survey, except Minnesota analyses by Minnesota Department of Health. Map number is location in figure 6. Site identification number is the well label in the U.S. Geological Survey WATSTORE data base]

\begin{tabular}{|c|c|c|c|c|c|c|c|c|c|c|}
\hline $\begin{array}{l}\text { Map } \\
\text { no. }\end{array}$ & $\begin{array}{c}\text { Site } \\
\text { Identification } \\
\text { number }\end{array}$ & $\begin{array}{c}\text { Date } \\
\text { of } \\
\text { sanple }\end{array}$ & $\begin{array}{c}\text { Arsenic, } \\
\text { As }\end{array}$ & $\begin{array}{c}\text { Boron, } \\
\text { B }\end{array}$ & $\begin{array}{c}\text { Bariua, } \\
\text { Ba }\end{array}$ & $\begin{array}{c}\text { Bronide, } \\
\text { Br } \\
(a g / L)\end{array}$ & $\begin{array}{c}\text { Cadiun } \\
\text { Cd }\end{array}$ & $\begin{array}{c}\text { Cobalt } \\
\text { Co }\end{array}$ & $\begin{array}{l}\text { Chro- } \\
\text { iun. } \\
\text { Cr }\end{array}$ & $\begin{array}{c}\text { Copper, } \\
\mathrm{Cu}\end{array}$ \\
\hline
\end{tabular}

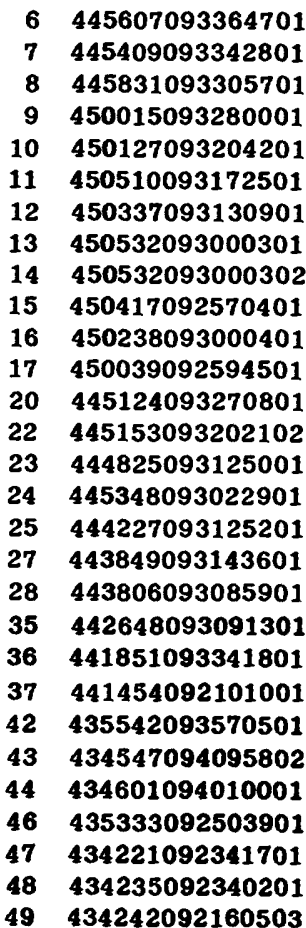

161402842092511801 162400217091295201

163391622091343301

164383543092103001

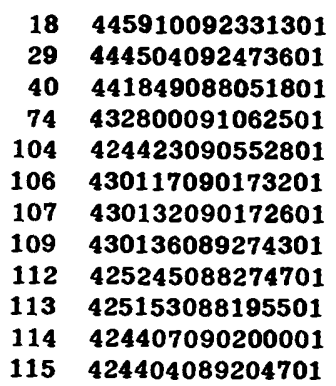

Aquifer layer 3, Minnesota
05-19-80 05-19-80 05-19-80 05-14-80 05-14-80 05-14-80 05-14-80 $05-12-80$ 05-12-80 05-12-80 05-12-80 05-14-80 05-20-80 05-20-80 05-22-80 05-21-80 05-21-80 01-30-80 05-21-80 05-21-80 09-03-80 02-12-80 02-29-80 01-29-80 $02-29-80$ 09-02-80 05-07-80 05-07-80 05-06-80

04-07-81 04-07-81 $04-06-81$ 04-06-81

\begin{tabular}{|c|c|c|c|}
\hline$<1$ & 210 & 110 & -- \\
\hline$<1$ & 10 & 160 & -- \\
\hline 11 & 10 & 270 & -- \\
\hline$<1$ & 80 & 75 & -- \\
\hline$<1$ & 110 & 11 & - \\
\hline$<1$ & 100 & 90 & -- \\
\hline$<1$ & 80 & 63 & -- \\
\hline-- & -- & -- & - \\
\hline$<1$ & $<50$ & 59 & -- \\
\hline$<1$ & $<50$ & 13 & - \\
\hline$<1$ & $<50$ & 25 & $-\infty$ \\
\hline$<1$ & 90 & 110 & -- \\
\hline 1 & 70 & 190 & -- \\
\hline 1 & 240 & 150 & -- \\
\hline 2 & 80 & 190 & -- \\
\hline$<1$ & 80 & 53 & - \\
\hline$<1$ & 110 & 120 & -- \\
\hline 2 & 400 & 17 & - \\
\hline$<1$ & 70 & 91 & -- \\
\hline$<1$ & 90 & 50 & - \\
\hline 1 & 30 & 110 & $-\infty$ \\
\hline$<1$ & $<50$ & 57 & - \\
\hline 5 & 20 & 46 & -- \\
\hline 6 & 270 & 47 & -- \\
\hline 6 & 20 & 44 & -- \\
\hline 1 & 90 & 80 & - \\
\hline$<1$ & 120 & 48 & -- \\
\hline 1 & 80 & 44 & -- \\
\hline$<1$ & $<50$ & 35 & - \\
\hline
\end{tabular}

Aquifer layer 3, Missouri

\begin{tabular}{|c|c|c|}
\hline$<3$ & $<1$ & $<10$ \\
\hline$<3$ & $<1$ & 21 \\
\hline$<3$ & $<1$ & 15 \\
\hline$<3$ & $<1$ & 11 \\
\hline$<3$ & $<1$ & $<10$ \\
\hline$<3$ & $<1$ & $<10$ \\
\hline$<3$ & $<1$ & 12 \\
\hline-- & -- & -- \\
\hline$<3$ & $<1$ & $<10$ \\
\hline$<3$ & $<1$ & $<10$ \\
\hline$<3$ & $<1$ & $<10$ \\
\hline$<3$ & $<1$ & $<10$ \\
\hline$<3$ & 8 & $<10$ \\
\hline$<3$ & 7.9 & $<10$ \\
\hline$<3$ & $<1$ & -- \\
\hline$<3$ & $<1$ & $<10$ \\
\hline-- & -- & - \\
\hline$<3$ & $<1$ & $<10$ \\
\hline$<3$ & $<1$ & $<10$ \\
\hline$<3$ & $<1$ & $<10$ \\
\hline$<3$ & -- & $<10$ \\
\hline$<3$ & 1 & $<10$ \\
\hline$<3$ & 1 & $<10$ \\
\hline$<3$ & $<1$ & $<10$ \\
\hline$<3$ & $<1$ & $<10$ \\
\hline$<3$ & $<1$ & 30 \\
\hline$<3$ & $<1$ & $<10$ \\
\hline$<3$ & $-\infty$ & $<10$ \\
\hline$<3$ & $<1$ & 16 \\
\hline
\end{tabular}

$\begin{array}{lrrrrrrr}0 & 2100 & 30 & 3.0 & 2 & <3 & -- & 0 \\ 0 & 3100 & 30 & 5.6 & 13 & <3 & -- & 0 \\ 0 & 2200 & 40 & 1.0 & 1 & <3 & -- & 0 \\ 0 & 320 & 100 & .10 & 3 & <3 & -- & 0\end{array}$

Aquifer layer 3, Wisconsin

$\begin{array}{rrrrrrrr}0 & <20 & 20 & .60 & 2 & <3 & -- & <10 \\ 1 & <20 & 20 & .90 & 4 & <3 & -- & <10 \\ 7 & 400 & 20 & .90 & 4 & <3 & -- & <10 \\ 0 & <20 & 30 & <.10 & 1 & 3 & -- & 10 \\ 1 & 30 & 160 & .40 & 4 & <3 & -- & <10 \\ 1 & 30 & 30 & .30 & 6 & 4 & -- & <10 \\ 1 & 30 & 30 & .30 & 3 & <3 & -- & <10 \\ 2 & 30 & 90 & <.10 & 6 & <3 & -- & <10 \\ 0 & 80 & 950 & <.10 & <1 & <3 & -- & <10 \\ - & - & 150 & -- & -- & -- & -- & -- \\ 1 & 30 & 40 & .10 & 5 & 4 & -- & <10 \\ 1 & 80 & 40 & .30 & 3 & <3 & -- & <10\end{array}$

Aquifer layer 4, Minnesota

$\begin{array}{llllllll}5 & 250 & 60 & .10 & 11 & <3 & -- & <10\end{array}$

Aquifer layer 4, Wisconsin 
TABLE 2.-Chemical analyses of selected trace constituents in water from wells sampled for this study-Continued

[Results in micrograms per liter, except as indicated. Analyses by U.S. Geological Survey, except Minnesota analyses by Minnesota Department of Health. Map number is location in figure 6. Site identification number is the well label in the U.S. Geological Survey WATSTORE data base]

\begin{tabular}{|c|c|c|c|c|c|c|c|c|c|c|c|}
\hline $\begin{array}{l}\text { Map } \\
\text { no. }\end{array}$ & $\begin{array}{l}\text { Fluo- } \\
\text { ride, } \\
\text { P } \\
(\mathrm{mg} / \mathrm{L})\end{array}$ & $\begin{array}{c}\text { Iron, } \\
\text { Fe }\end{array}$ & $\begin{array}{c}\text { Lith- } \\
\text { iun, } \\
\text { LI }\end{array}$ & $\begin{array}{c}\text { Manga- } \\
\text { nese, } \\
\text { Mn }\end{array}$ & $\begin{array}{c}\text { Molyb- } \\
\text { denum, } \\
\text { Mo }\end{array}$ & $\begin{array}{c}\text { Lead, } \\
\text { Pb }\end{array}$ & $\begin{array}{l}\text { Sele- } \\
\text { niun, } \\
\text { Se }\end{array}$ & $\begin{array}{c}\text { Stron- } \\
\text { tium, } \\
\text { Sr }\end{array}$ & $\begin{array}{c}\text { Vana- } \\
\text { diue, } \\
\text { Va }\end{array}$ & $\begin{array}{c}\text { Beryl- } \\
\text { lium, } \\
\text { Be }\end{array}$ & $\begin{array}{c}\text { Sulfide, } \\
\text { S } \\
(\mathrm{mg} / \mathrm{L})\end{array}$ \\
\hline
\end{tabular}

Aquifer layer 3, Minnesota

$\begin{array}{rrr}6 & .30 & 330 \\ 7 & .20 & 1200 \\ 8 & .20 & 1200 \\ 9 & .24 & <50 \\ 10 & .26 & 430 \\ 11 & .18 & <50 \\ 12 & .20 & <50 \\ 13 & -- & - \\ 14 & .27 & 640 \\ 15 & .18 & <50 \\ 16 & .19 & 50 \\ 17 & .18 & <50 \\ 20 & .18 & 590 \\ 22 & .24 & 430 \\ 23 & .12 & <50 \\ 24 & .12 & <50 \\ 25 & .14 & 130 \\ 27 & .15 & 1120 \\ 28 & .12 & 200 \\ 35 & .14 & 160 \\ 36 & .40 & 39 \\ 37 & .17 & <50 \\ 42 & .43 & 660 \\ 43 & .18 & 2200 \\ 44 & .28 & 2400 \\ 46 & .40 & 200 \\ 47 & .37 & 320 \\ 48 & .40 & 150 \\ 49 & .24 & 240\end{array}$

$\begin{array}{rrrr}14 & 190 & <10 & <10 \\ 11 & 230 & <10 & <10 \\ 6 & <20 & <10 & <10 \\ 6 & 320 & <10 & <10 \\ 8 & 470 & <10 & - \\ 4 & 280 & <10 & <10 \\ 3 & 320 & <10 & <10 \\ 3 & -- & <10 & <10 \\ 7 & 30 & <10 & <10 \\ 2 & 70 & <10 & <10 \\ 4 & <20 & <10 & <10 \\ 2 & <50 & <1 & - \\ 5 & 70 & 3 & <10 \\ 5 & 30 & 3 & <10 \\ 5 & 140 & 2 & <10 \\ 12 & 20 & 1 & <10 \\ 7 & 1000 & <1 & <10 \\ 7 & 22 & <1 & <10 \\ 5 & 40 & 2 & <10 \\ 7 & 90 & <10 & <10 \\ 29 & 330 & <10 & 44 \\ 5 & <20 & <1 & <10 \\ 29 & 190 & 15 & <10 \\ 29 & 200 & 2 & <10 \\ 17 & 300 & 4 & <10 \\ 8 & 22 & <10 & 51 \\ 8 & 20 & <1 & <10 \\ 8 & 20 & 1 & <10 \\ 3 & 20 & <1 & 1\end{array}$

$$
\begin{array}{r}
1 \\
<1 \\
<1 \\
1 \\
<1 \\
<1 \\
<1 \\
<1 \\
<1 \\
<1 \\
<1 \\
<1 \\
<1 \\
<1 \\
<1 \\
2 \\
<1 \\
1 \\
<1 \\
<1 \\
<1 \\
<1 \\
3 \\
2 \\
2 \\
1 \\
<1 \\
1 \\
<1 \\
\hline
\end{array}
$$

$\begin{array}{cccc}-- & -- & -- & - \\ -- & -- & -- & - \\ -- & -- & -- & - \\ -- & -- & -- & - \\ -- & -- & -- & - \\ -- & -- & -- & - \\ -- & -- & - & - \\ -- & -- & - & - \\ -- & -- & -- & - \\ -- & -- & -- & - \\ -- & -- & -- & - \\ -- & -- & -- & - \\ -- & -- & -- & - \\ -- & -- & -- & - \\ -- & -- & -- & - \\ -- & -- & -- & - \\ -- & -- & -- & - \\ -- & -- & -- & - \\ -- & -- & -- & - \\ -- & -- & -- & - \\ 450 & <6 & <.7 & - \\ -- & -- & -- & - \\ -- & -- & -- & - \\ -- & -- & -- & - \\ -- & -- & -- & - \\ 320 & <6 & <. & - \\ -- & -- & -- & - \\ -- & -- & -- & - \\ -- & -- & -- & -\end{array}$

Aquifer layer 3, Missouri

\begin{tabular}{|c|c|c|c|c|c|c|c|c|c|c|c|}
\hline 161 & 5.1 & 110 & 390 & 21 & 0 & $<10$ & $<1$ & 4500 & 0 & $<.7$ & -- \\
\hline 162 & 4.7 & 12 & 680 & 19 & 0 & 25 & $<1$ & 9300 & 0 & $<.7$ & -- \\
\hline 163 & 2.7 & 140 & 230 & 9 & 0 & $<10$ & $<1$ & 2400 & 0 & $<.7$ & - \\
\hline 164 & 1.2 & 130 & 37 & 18 & 0 & $<10$ & $<1$ & 570 & 0 & $<.7$ & -- \\
\hline
\end{tabular}

Aquifer layer 3, Nisconsin

$\begin{array}{rcrr}18 & .20 & <3 & < \\ 29 & .10 & <3 & < \\ 40 & 1.3 & 2500 & 9 \\ 74 & .10 & 6 & \\ 104 & .20 & <3 & \\ 106 & .20 & 7 & < \\ 107 & .10 & 45 & < \\ 109 & .10 & 14 & < \\ 112 & .30 & 440 & \\ 113 & .30 & 120 & \\ 114 & .20 & 3 & < \\ 115 & .10 & 59 & <\end{array}$

45

$\begin{array}{rrr}<1 & <10 & <10 \\ 1 & <10 & 14 \\ 65 & <10 & 18 \\ 1 & 10 & 10 \\ 2 & <10 & 13 \\ 1 & <10 & 17 \\ 7 & <10 & <10 \\ 2 & 21 & <10 \\ 6 & <10 & <10 \\ 21 & -- & -- \\ 2 & <10 & <10 \\ 190 & <10 & <10\end{array}$

$\begin{array}{lr}<1 & 34 \\ <1 & 21 \\ <1 & 15000 \\ <1 & 62 \\ <1 & 120 \\ <1 & 50 \\ <1 & 15 \\ <1 & 78 \\ <1 & 1200 \\ -- & 1200 \\ <1 & 58 \\ <1 & 58\end{array}$

$<6$
$<6$
$<6$
6
$<6$
$<6$
$<6$
$<6$
$<6$
--
$<6$
$<6$

$<.7$

$<.1$

$<.7<.1$

$1.0<.1$

$<.7<.1$

$<.7<.1$

$<.7<.1$

$<.7 \quad-$

$\begin{array}{ll}<.7 & .6 \\ -- & --\end{array}$

$<.7 \quad<.1$

Aquifer layer 4, Minnesota

$\begin{array}{lllllll}100 & <10 & 55 & <1 & 190 & <6 & <.7\end{array}$

Aquifer layer 4 , Wisconsin 
TABLE 2.-Chemical analyses of selected trace constituents in water from wells sampled for this study-Continued

[Results in micrograms per liter, except as indicated. Analyses by U.S. Geological Survey, except Minnesota analyses by Minnesota Department of Health. Map number is location in figure 6. Site identification number is the well label in the U.S. Geological Survey WATSTORE data base]

\begin{tabular}{|c|c|c|c|c|c|c|c|c|c|c|}
\hline $\begin{array}{l}\text { Map } \\
\text { no. }\end{array}$ & $\begin{array}{c}\text { Site } \\
\text { identification } \\
\text { number }\end{array}$ & $\begin{array}{l}\text { Date } \\
\text { of } \\
\text { sample }\end{array}$ & $\begin{array}{c}\text { Arsenic, } \\
\text { As }\end{array}$ & $\begin{array}{c}\text { Boron, } \\
\text { B }\end{array}$ & $\begin{array}{c}\text { Bariun, } \\
\text { Ba }\end{array}$ & $\begin{array}{c}\text { Bromide, } \\
\text { Br } \\
(\mathrm{mg} / \mathrm{L})\end{array}$ & $\begin{array}{c}\text { Cadniun, } \\
\text { Cd }\end{array}$ & $\begin{array}{c}\text { Cobalt, } \\
\text { Co }\end{array}$ & $\begin{array}{l}\text { Chro- } \\
\text { mium. } \\
\text { Cr }\end{array}$ & $\begin{array}{c}\text { Copper, } \\
\text { Cu }\end{array}$ \\
\hline
\end{tabular}

\begin{tabular}{ll}
58 & 425526096210711 \\
60 & 431620095250511 \\
81 & 430512095371801 \\
82 & 425824095300901 \\
83 & 430745094541101 \\
85 & 424348095231601 \\
86 & 424348095231602 \\
87 & 423618095194511 \\
89 & 422950095174301 \\
\hline 90 & 422009095210101
\end{tabular}

2462710092454001

$26 \quad 443710093453501$

41440026094355401

$09-03-80$
$09-03-80$
$02-23-82$
$02-23-82$
$02-23-82$
$04-15-80$
$09-04-80$
$09-04-80$
$02-22-82$
$02-22-82$

02-21-80

09-03-80

09-03-80
Aquifer layer 5, Iowa

$\begin{array}{rrrrrrrr}2 & 480 & 20 & .60 & 6 & <3 & -- & <10 \\ 3 & 280 & 20 & .10 & 6 & <3 & -- & 13 \\ <50 & -- & 9 & -- & <2 & -- & <5 & <10 \\ <50 & -- & 9 & -- & <2 & -- & <5 & <10 \\ <50 & -- & 13 & -- & <2 & -- & <5 & <10 \\ <10 & -- & <100 & -- & 1 & -- & <1 & <10 \\ 2 & 150 & 30 & <.10 & 4 & <3 & -- & <10 \\ 10 & 340 & 30 & .20 & 6 & 6 & -- & <10 \\ <50 & -- & 8 & -- & <2 & -- & <5 & <10 \\ <50 & -- & 10 & -- & <2 & -- & <5 & <10\end{array}$

Aquifer layer 5, Minnesota

\begin{tabular}{rrrrrrrr}
$<1$ & 120 & 49 & -5 & $<1$ & $<3$ & $<1$ & $<10$ \\
5 & 220 & 70 & .40 & 9 & $<3$ & -- & $<10$ \\
9 & 110 & 160 & $<.10$ & 11 & $<3$ & -- & $<10$ \\
\hline
\end{tabular}


TABLE 2.-Chemical analyses of selected trace constituents in water from wells sampled for this study-Continued

[Results in micrograms per liter, except as indicated. Analyses by U.S. Geological Survey, except Minnesota analyses by Minnesota Department of Health. Map number is location in figure 6. Site identification number is the well label in the U.S. Geological Survey WATSTORE data base]

\begin{tabular}{|c|c|c|c|c|c|c|c|c|c|c|c|}
\hline $\begin{array}{l}\text { Map } \\
\text { no. }\end{array}$ & $\begin{array}{l}\text { Fluo- } \\
\text { ride, } \\
F \\
(\mathrm{mg} / \mathrm{L})\end{array}$ & $\begin{array}{c}\text { Iron, } \\
\text { Pe }\end{array}$ & $\begin{array}{c}\text { Lith- } \\
\text { Ium, } \\
\text { Li }\end{array}$ & $\begin{array}{c}\text { Manga- } \\
\text { nese, } \\
\text { Mn }\end{array}$ & $\begin{array}{c}\text { Molyb- } \\
\text { denum, } \\
\text { Mo }\end{array}$ & $\begin{array}{c}\text { Lead, } \\
\mathbf{P b}\end{array}$ & $\begin{array}{l}\text { Sele- } \\
\text { nium. } \\
\text { Se }\end{array}$ & $\begin{array}{c}\text { Stron- } \\
\text { tium, } \\
\text { Sr }\end{array}$ & $\begin{array}{l}\text { Vana- } \\
\text { dium. } \\
\text { Va }\end{array}$ & $\begin{array}{c}\text { Beryl- } \\
\text { lium, } \\
\text { Be }\end{array}$ & $\begin{array}{c}\text { Sulfide, } \\
\text { S } \\
(\mathrm{mg} / \mathrm{L})\end{array}$ \\
\hline \multicolumn{12}{|c|}{ Aquifer layer 5, Iowa } \\
\hline 58 & .80 & 140 & 170 & 230 & $<10$ & 22 & $<1$ & 4300 & $<6$ & $<.7$ & -- \\
\hline 60 & .30 & 78 & 110 & 720 & $<10$ & 28 & $<1$ & 2600 & $<6$ & $<.7$ & -- \\
\hline 81 & - & 1400 & - & - & - & - & $<5$ & - & -- & -- & $<.1$ \\
\hline 82 & .57 & 2500 & -- & 640 & -- & $<50$ & $<5$ & -- & -- & -- & $<.1$ \\
\hline 83 & .36 & 4200 & -- & 270 & -- & $<50$ & $<5$ & - & -- & - & $<.1$ \\
\hline 85 & 2.0 & 30 & -- & 130 & -- & $<10$ & $<10$ & -- & - & - & - \\
\hline 86 & .40 & 34 & 33 & 210 & $<10$ & 20 & $<1$ & 770 & $<6$ & $<.7$ & - \\
\hline 87 & .50 & 27 & 45 & 220 & $<10$ & 20 & $<1$ & 1100 & $<6$ & $<.7$ & -- \\
\hline 89 & .43 & 71 & -- & 2600 & - & $<50$ & $<5$ & - & -- & -- & $<.1$ \\
\hline 90 & .82 & 2900 & -- & 460 & -- & $<50$ & $<5$ & -- & -- & -- & $<.1$ \\
\hline \multicolumn{12}{|c|}{ Aquifer layer 5, Minnesota } \\
\hline 2 & .15 & $<0$ & 6 & $<0$ & $<1$ & $<10$ & 3 & -- & -- & - & -- \\
\hline 26 & .30 & 1500 & 20 & 710 & $<10$ & 34 & $\mathbf{0}$ & 370 & $<6$ & $<.7$ & -- \\
\hline 41 & .20 & 1800 & 17 & 320 & $<10$ & 34 & 1 & 240 & $<6$ & $<.7$ & - \\
\hline
\end{tabular}




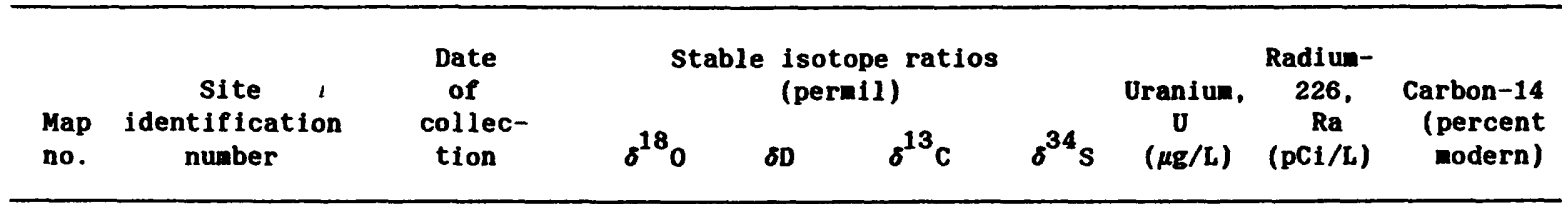

118422418090255501 130422803087475303 131422803087475304

71432953091172001

73432206091130301 102430240091110001 119420842090165702

1461209093550701 19445704093215611 $30 \quad 443354092323201$ 32443300092302901 51440324091401501 52440318091388180

33443436091281401 34443841090393001 38442141091185601 39442045090453601 $54 \quad 435743089485701$ $55 \quad 440219088555701$ 56434312090353901 57433921091132101 75432336090460601 $76 \quad 432042090231701$ 77433144089595901 78433220089282601 $79 \quad 431849089311002$ 80432717088501701 103425246091042101 105431108090263101 108430055089534001 109430136089274301 110430058089251401

120422606089434501 121421331089442201 122421658089235101

123422738089114601

124422545089103301

125421855089121601

126421614089062301

127420953089080501

128421025088564401

129421329088531701

132422803087475306

133415632088071201

135413847088214801

$136 \quad 411858088363401$

137411933089403701

Aquifer layer 1, Illinois

10-23-80 12-10-80 01-14-81

06-24-80 06-10-80 06-09-80 05-15-81

02-21-80 09-04-80 02-12-80 02-12-80 02-13-80 02-13-80

08-06-80 $08-20-80$ 08-13-80 08-20-80 08-21-80 08-19-80 08-22-80 10-08-81 $08-28-80$ 08-28-80 09-05-80 09-05-80 $07-24-80$ 09-05-80 08-19-81 08-29-80 07-18-80 05-12-80 $07-22-80$

$08-29-80$ 08-29-80 08-20-80 $08-23-80$ 08-23-80 08-23-80 09-03-80 09-05-80 09-04-80 09-05-80 09-01-81 06-21-80 08-27-80 08-28-80 08-28-80

$\begin{array}{llll}-8.4 & -54.0 & - & - \\ -9.3 & -63.0 & - & 8.7 \\ -9.0 & -57.5 & -- & \end{array}$

Aquifer layer 1, Iowa

$\begin{array}{lll}-8.4 & -55.0 & -11.7 \\ -8.8 & -54.5 & -11.3 \\ -9.2 & -56.5 & -10.0 \\ -8.4 & -58.0 & -11.1\end{array}$

Aquifer layer 1, Minnesota

$\begin{array}{rrr}-9.6 & -64.5 & -13.2 \\ -10.0 & -67.0 & -9.9 \\ -10.2 & -68.0 & -10.2 \\ -9.2 & -60.5 & -12.4 \\ -9.5 & -61.5 & -12.5\end{array}$

$\begin{array}{ll}- & <.6 \\ - & <.5 \\ - & <.6 \\ - & <.6 \\ - & <.5 \\ - & <.5\end{array}$

$\begin{array}{cc}1.7 & -- \\ 2.8 & -- \\ 5.5 & -- \\ 11 & -- \\ 4.6 & -- \\ 2.8 & --\end{array}$

Aqui fer layer 1, Wisconsin

$\begin{array}{rrrrrrr}-9.2 & -65.5 & -14.4 & -- & <.6 & .2 & -- \\ -- & -- & -- & -- & <.6 & .4 & -- \\ -9.2 & -63.0 & -12.3 & -- & <.7 & .5 & - \\ -- & -- & -- & -- & <.6 & .3 & - \\ -9.4 & -62.5 & -14.2 & -- & 2.0 & .5 & - \\ -- & -- & -- & -- & 3.7 & .5 & -- \\ -- & -- & -- & -- & <.5 & .2 & -- \\ -- & -- & -- & -- & <.6 & 2.2 & - \\ -- & -- & -- & -- & <.6 & .9 & - \\ -- & -- & -- & -- & <.6 & .7 & - \\ -- & -- & -- & -- & <.6 & .5 & - \\ -- & -- & -- & -- & <.6 & .2 & - \\ -8.8 & -60.0 & -8.2 & -- & .9 & <.1 & - \\ -- & -- & -- & -- & <.6 & 5.9 & - \\ -8.6 & -56.5 & -11.0 & -- & .7 & 2.8 & - \\ -- & -- & -- & -- & <.5 & 1.7 & - \\ -- & -- & -- & -- & .7 & .8 & - \\ -9.4 & -60.0 & -13.1 & -- & 22 & <.1 & - \\ -8.8 & -51.0 & -8.6 & -- & .8 & 1.2 & - \\ & & & & & & -\end{array}$

Aquifer layer 3, Illinois

$\begin{array}{rrr}-7.4 & -47.5 & -8.4 \\ -8.0 & -50.5 & -12.6 \\ -8.4 & -52.5 & - \\ -8.8 & -58.0 & -14.0 \\ -8.6 & -56.0 & -12.3 \\ -7.4 & -49.5 & -7.3 \\ -8.4 & -54.5 & -14.0 \\ -7.4 & -46.0 & -8.2 \\ -- & -- & -7.9 \\ -8.4 & -51.5 & -9.4 \\ -9.6 & -68.5 & -- \\ -8.9 & -64.0 & -14.6 \\ -9.5 & -61.5 & -11.8 \\ -9.0 & -60.5 & -10.6 \\ -9.4 & -61.5 & -11.3\end{array}$

$\begin{array}{rcr}<.6 & 1.1 & - \\ <.6 & 6.9 & - \\ 28.9 & 99 & -\end{array}$

$<.3$

.2

$<.6$

2.2
$-$ 
TABLE 3-Analyses of stable isotopes, uranium, and radium-226 in water from selected wells sampled for this studyContinued

[Analyses by U.S. Geological Survey. Map number is location in figure 6. Site identification number is the well label in the U.S. Geological Survey WATSTORE data base]

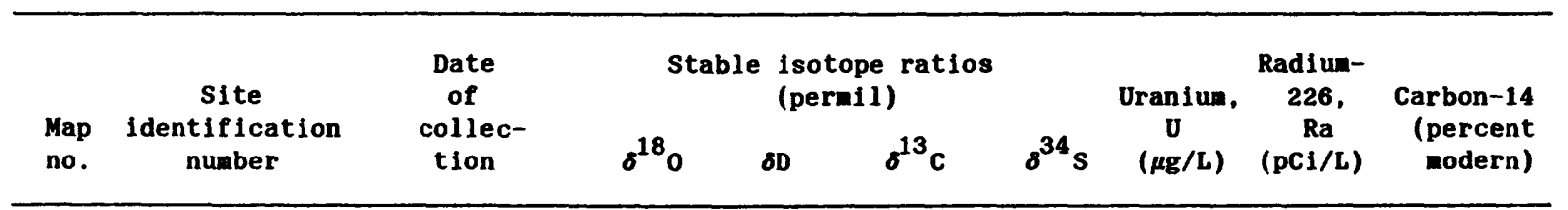

161402842092511801

162400217091295201

163391622091343301

164383543092103001

$18 \quad 445910092331301$ 29444504092473601

$40 \quad 441849088051801$

74432800091062501

104424423090552801

106430117090173201

107430132090172601

112425245088274701

113425153088195501

114424407090200001

115424404089204701

$45 \quad 433615093403001$

09-02-80

$11-21-80$

58425526096210711 $\begin{array}{ll}60 & 431620095250511\end{array}$

81430512095371801 82425824095300901 83430745094541101 85424348095231601 $86 \quad 424348095231602$ 87423618095194511 89422950095174301 $90 \quad 422009095210101$

2 462710092454001 $26 \quad 443710093453501$ 41440026094355401

04-07-81

04-07-81

04-06-81

04-06-81

08-04-80 08-08-80

11-10-81

08-26-80

08-27-80

08-27-80

05-29-80

10-21-82

08-26-80

09-04-80

02-20-80

09-03-80

09-03-80 08-14-80

$\begin{array}{lll}-9.6 & -63.0 & -14.4\end{array}$

$-13.9-104.0$

$-14.8-112.0$

$-7.2-49.0$

$-7.0$

$-46.0$

$-6.2$

-6.1
-7.6

$-9.0$

Aquifer layer 3, Wisconsin

\begin{tabular}{|c|c|c|}
\hline-10.5 & -- & -13.4 \\
\hline-9.4 & -- & -6.2 \\
\hline-14.0 & -98.0 & -12.6 \\
\hline-- & -- & -- \\
\hline-- & -- & - \\
\hline-9.0 & -59.0 & -10.7 \\
\hline-- & -- & -6.2 \\
\hline-8.6 & -56.5 & -9.0 \\
\hline-- & -- & - \\
\hline-- & -- & -6.1 \\
\hline-9.2 & -62.0 & -13.0 \\
\hline
\end{tabular}

$\begin{array}{rr}-- & <.6 \\ -- & 1.5 \\ -- & 1.4 \\ -- & <.6 \\ -- & .9 \\ -- & <.5 \\ -- & <.6 \\ -- & <.5 \\ -- & -- \\ -- & 1.0 \\ -- & <.6\end{array}$

Aquifer layer 4, Minnesota

$1.2 \quad .3$

Aquifer layer 4, Wisconsin

$\begin{array}{rrrr}-- & <.6 & 3.3 & -- \\ -- & <.6 & 31 & -- \\ - & 1.9 & 3.4 & -- \\ - & .8 & 2.1 & --\end{array}$

Aquifer layer 5, Iowa

$\begin{array}{rrrrrrrr}09-03-80 & -- & -- & -- & -- & <.5 & .8 & -- \\ 09-03-80 & -- & -- & -- & -- & 1.6 & .8 & -- \\ 02=23-82 & -- & -- & -- & -7.5 & -- & -- & -- \\ 02-23-82 & -- & -- & -- & -10.0 & -- & -- & -- \\ 02-23-82 & -- & -- & -- & -7.5 & -- & -- & -- \\ 09-04-80 & -8.1 & -55.5 & -14.2 & -- & <.5 & .1 & -- \\ 09-04-80 & -8.6 & -57.5 & -7.6 & -- & 6.1 & .1 & -- \\ 09-04-80 & -- & -- & -- & -- & 1.3 & .3 & -- \\ 02-22-82 & -- & -- & -- & -8.0 & -- & -- & -- \\ 02-22-82 & -- & -- & -- & -10.8 & -- & -- & --\end{array}$

Aquifer layer 5, Minnesota

$\begin{array}{ll}-- & 1.1 \\ -- & 3.2\end{array}$

$-\infty$ 


\section{SELECTED SERIES OF U.S. GEOLOGICAL SURVEY PUBLICATIONS}

\section{Perlodicals}

Earthquakes \& Volcanoes (issued bimonthly).

Preliminary Determination of Eplcenters (issued monthly).

\section{Technical Books and Reports}

Professional Papers are mainly comprehensive scientific reports of wide and lasting interest and importance to professional scientists and engineers. Included are reports on the results of resource studies and of topographic, hydrologic, and geologic investigations. They also include collections of related papers addressing different aspects of a single scientific topic.

Bulletins contain significant data and interpretations that are of lasting scientific interest but are generally more limited in scope or geographic coverage than Professional Papers. They include the results of resource studies and of geologic and topographic investigations; as well as collections of short papers related to a specific topic.

Water-Supply Papers are comprehensive reports that present significant interpretive results of hydrologic investigations of wide interest to professional geologists, hydrologists, and engineers. The series covers investigations in all phases of hydrology, including hydrogeology, availability of water, quality of water, and use of water.

Circulars present administrative information or important scientific information of wide popular interest in a format designed for distribution at no cost to the public. Information is usually of short-term interest.

Water-Resources Investigations Reports are papers of an interpretive nature made available to the public outside the formal USGS publications series. Copies are reprociuced on request unlike formal USGS publications, and they are also available for public inspection at depositories indicated in USGS catalogs.

Open-File Reports include unpublished manuscript reports, maps, and other material that are made available for public consultation at depositories. They are a nompermanent form of publication that may be cited in other publications as sources of information.

\section{Maps}

Geologic Quadrangle Maps are multicolor geologic maps on topographic bases in 71/2- or 15-minute quadrangle formats (scales mainly $1: 24,000$ or $1: 62,500$ ) showing bedrock, surficial, or engineering geology. Maps generally include brief texts; some maps include structure and columnar sections only.

Geophysical Investigations Maps are on topographic or planimetric bases at various scales; they show results of surveys using geophysical techniques, such as gravity, magnetic, seismic, or radioactivity, which reflect subsurface structures that are of economic or geologic significance. Many maps include correlations with the geology.

Miscellaneous Investigations Series Maps are on planimetric or topographic bases of regular and irregular areas at various scales; they present a wide variety of format and subject matter. The series also includes 71/2-minute quadrangle photogeologic maps on planimetric bases which show geology as interpreted from aerial photographs. Series also includes maps of Mars and the Moon.
Coal Investigations Maps are geologic maps on topographic or planimetric bases at various scales showing bedrock or surficial geology, stratigraphy, and structural relations in certain coal-resource areas.

Oll and Gas Investigations Charts show stratigraphic information for certain oil and gas fields and other areas having petroleum potential.

Miscellaneous Field Studies Maps are multicolor or black-andwhite maps on topographic or planimetric bases on quadrangle or irregular areas at various scales. Pre-1971 maps show bedrock geology in relation to specific mining or mineral-deposit problems; post-1971 maps are primarily black-and-white maps on various subjects such as environmental studies or wildemess mineral investigations.

Hydrologlc Investigations Atiases are multicolored or black-andwhite maps on topographic or planimetric bases presenting a wide range of geohydrologic data of both regular and irregular areas; principal scale is $1: 24,000$ and regional studies are at $1: 250,000$ scale or smaller.

\section{Catalogs}

Permanent catalogs, as well as some others, giving comprehensive listings of U.S. Geological Survey publications are available under the conditions indicated below from the U.S. Geological Survey, Books and Open-File Reports Section, Federal Center, Box 25425, Denver, CO 80225. (See latest Price and Availability List.)

"Publications of the Geological Survey, 1879- 1961" may be purchased by mail and over the counter in paperback book form and as a set of microfiche.

"Publications of the Geological Survey, 1962- 1970" may be purchased by mail and over the counter in paperback book form and as a set of microfiche.

"Publications of the U.S. Geological Survey, 1971- 1981" may be purchased by mail and over the counter in paperback book form (two volumes, publications listing and index) and as a set of microfiche.

Supplements for $1982,1983,1984,1985,1986$, and for subsequent years since the last permanent catalog may be purchased by mail and over the counter in paperback book form.

State catalogs, "List of U.S. Geological Survey Geologic and Water-Supply Reports and Maps For (State)," may be purchased by mail and over the counter in paperback booklet form only.

"Price and Avallability List of U.S. Geological Survey Publications," issued annually, is available free of charge in paperback booklet form only.

Selected coples of a monthly catalog "New Publications of the U.S. Geological Survey" available free of charge by mail or may be obtained over the counter in paperback booklet form only. Those wishing a free subscription to the monthly catalog "New Publications of the U.S. Geological Survey" should write to the U.S. Geological Survey, 582 National Center, Reston, VA 22092.

Note.--Prices of Government publications listed in older catalogs, announcements, and publications may be incorrect. Therefore, the prices charged may differ from the prices in catalogs, announcements, and publications. 